\title{
MEDYCYNA NARRACYJNA
}

Opowieści o doświadczeniu choroby

w perspektywie medycznej i humanistycznej

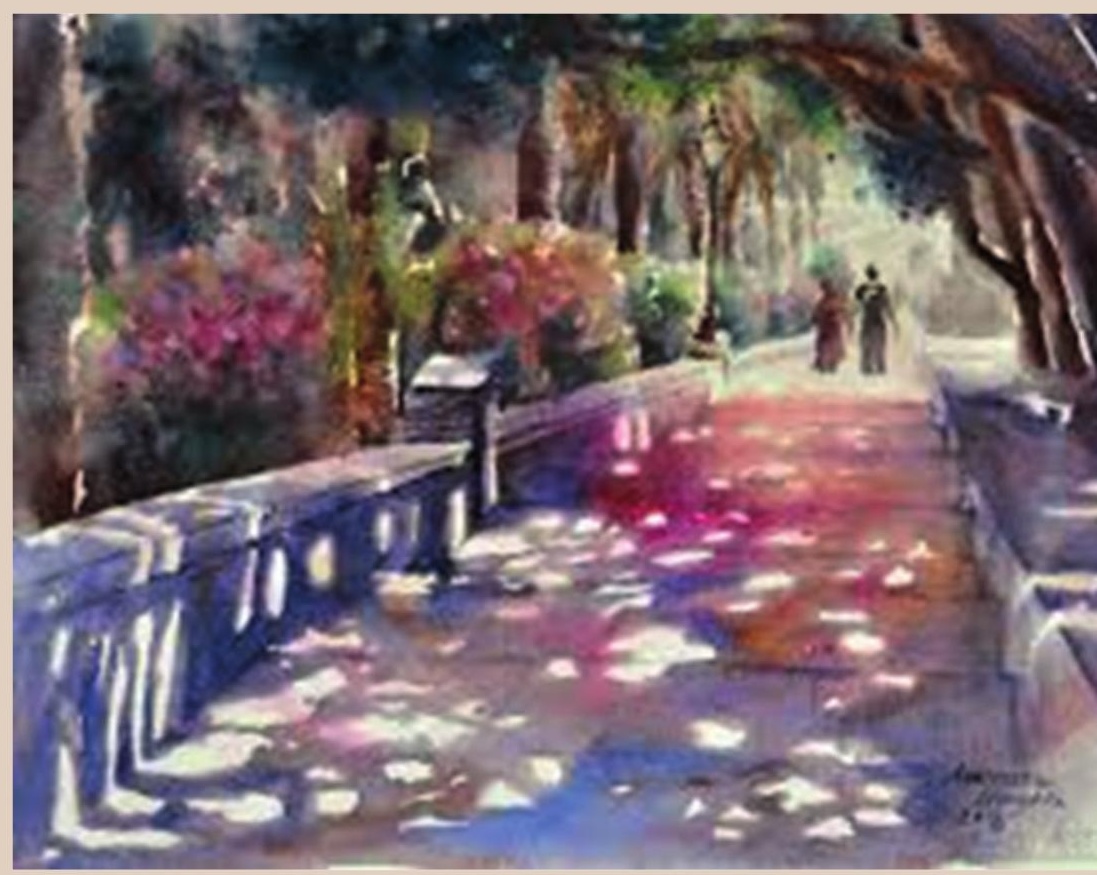

Redakcja naukowa

Marty Chojnackiej-Kuraś

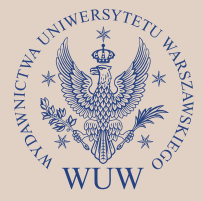


MEDYCYNA NARRACYJNA 


\section{MEDYCYNA NARRACYJNA}

Opowieści o doświadczeniu choroby w perspektywie medycznej i humanistycznej

redakcja naukowa

Marta Chojnacka-Kuraś

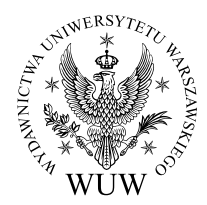


Recenzenci

dr hab. Jarostaw Barański

dr hab. Małgorzata Okupnik

Redaktor prowadzący

Małgorzata Yamazaki

Redakcja

Małgorzata Żakowska

Redakcja techniczna

Maryla Broda

Korekta

Agnieszka Fedorowicz

Indeks

Iwona Karpowicz-Dajczer

Projekt okładki i stron tytułowych

Magdalena Jędraszko

Ilustracja na okładce i stronach tytułowych rozdziałów Agnieszka Leszczyńska, W stronę światła

Skład i łamanie

Dariusz Górski

Publikacja dofinansowana przez Uniwersytet Warszawski

Publikacja dofinansowana przez Wydział Polonistyki UW

(C) Copyright by Wydawnictwa Uniwersytetu Warszawskiego, Warszawa 2019

ISBN 978-83-235-4067-0 (druk) ISBN 978-83-235-4075-5 (pdf online)

ISBN 978-83-235-4083-0 (e-pub) ISBN 978-83-235-4091-5 (mobi)

Wydawnictwa Uniwersytetu Warszawskiego

00-497 Warszawa, ul. Nowy Świat 4

e-mail: wuw@uw.edu.pl

księgarnia internetowa: www.wuw.pl

Wydanie 1, Warszawa 2019

Druk i oprawa

Pozkal 


\section{Spis treści}

Wstęp - Marta Chojnacka-Kuraś . . . . . . . . . . . . . . . . 7

\section{MEDYCYNA NARRACYJNA W PRAKTYCE KLINICZNEJ I DYDAKTYCE MEDYCZNEJ}

Medycyna narracyjna w Szwecji - Małgorzata Luber-Szumniak . . . . . .

„Opowiedz mi...”. Narracja w doświadczeniach ciąży, porodu i straty dziecka - Barbara Baranowska, Antonina Doroszewska, Urszula Tataj-

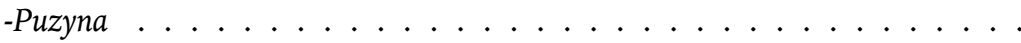

„Okaleczona kobiecość”. Z pamiętników kobiet z niepełnosprawnościami - Halina Kulik, Józefa Dąbek . . . . . . . . . . . . . . . . . .

\section{MEDYCYNA NARRACYJNA W UJĘCIU METODOLOGICZNYM}

Medycyna narracyjna z perspektywy lingwistyki i poetyki kognitywnej - Marta Chojnacka-Kuraś. . . . . . . . . . . . . . . . . . . . .

Żaden pacjent nie jest wyspą lub czego lekarze mogą nauczyć się w kontaktach z pacjentami - Hanna Serkowska . . . . . . . . . . . .

Metoda uważnego czytania (close reading) w medycynie narracyjnej - Aleksandra Szugajew . . . . . . . . . . . . . . . . .

NARRACJE W DYSKURSIE MEDYCZNYM

„Pamiętam, zdarzyło się to w sobotę rano, około 10”. Fachowe publikacje medyczne oparte na relacjach pacjentów i lekarzy - Magdalena Zabielska, Magda Żelazowska-Sobczyk . . . . . . . . . . . . . . . . . . . . 127 
Teoria grzeczności a konstruowanie spójności w narracjach lekarzy i pacjentów. Studium diagnozy w polskim dyskursie medycznym - Anna Kuzio . . . . . . . . . . . . . . . . . . . . . . . . . . . . . . . 142

\section{LITERATURA I MEDYCYNA - ŹRÓDŁA I PERSPEKTYWY}

Upojona chorobą. W trzewiach świata... Eve Ensler - Monika Ładoń . . . 167 „Ja rozumiałem, tylko nie mogłem mówić”. O twórczości Leo Lipskiego jako afatyka. Rekonesans - Olga Osińska . . . . . . . . . . . . 187 Śmierć ojca i narodziny matki - wzajemna analiza w „Dzienniku klinicznym” Sándora Ferencziego - Agnieszka Więckiewicz . . . . . . . . . . 205

Indeks osób . . . . . . . . . . . . . . . . . . . . 223 


\section{Wstęp}

Inspiracją do powstania niniejszej książki była konferencja naukowa „Medycyna narracyjna. Wartość opowieści o doświadczeniu choroby w praktyce klinicznej, badaniach i edukacji", która odbyła się w czerwcu 2018 roku na Uniwersytecie Warszawskim. Konferencja ta, otwierająca cykl spotkań dotyczących medycyny narracyjnej, zainicjowana została przez dr n. med. Aldonę Katarzynę Jankowską, która nawiązała bezpośrednią współpracę $z$ twórczynią narrative medicine, Ritą Charon $z$ Uniwersytetu Columbia w Nowym Jorku. W organizację wydarzenia zaangażowało się kilka podmiotów: Instytut Języka Polskiego UW, Zespół Języka Medycznego Rady Języka Polskiego przy Prezydium PAN, Pracownia Komunikacji w Medycynie Wydziału Lekarskiego Collegium Medicum UMK w Bydgoszczy, Polskie Towarzystwo Komunikacji Medycznej oraz Studium Komunikacji Medycznej Warszawskiego Uniwersytetu Medycznego.

Pomysłodawcy konferencji mieli świadomość, że tematyka medycyny narracyjnej jest $\mathrm{w}$ Polsce stosunkowo mało rozpoznana ${ }^{1}$, a w realiach szpitalnych czy w świadomości pacjentów niemal nieobecna. Jednocześnie towarzyszyło im przekonanie, że zasługuje ona na czas i uwagę. Nie dlatego, że wyznacza obecnie jeden $z$ ważniejszych kierunków rozwoju

${ }^{1}$ Nie oznacza to bynajmniej, że nie ma polskich publikacji na ten temat. Zagadnienie medycyny narracyjnej było podejmowane i opisywane przez polskich naukowców i lekarzy, szczególnie w aspekcie medycznym i socjologicznym. Najważniejsze $z$ tych prac są przywoływane w artykułach składających się na niniejszą monografię. 
współczesnej refleksji nad medycyną na świecie, tylko dlatego, że dotyka samej istoty medycyny: spotkania człowieka z człowiekiem. I jako taka warta jest tego, aby zaaranżować spotkanie osób zajmujących się problematyką narracji w medycynie, choćby była ich tylko garstka. $\mathrm{Ku}$ radości organizatorów okazało się, że w różnych ośrodkach naukowych w kraju są specjaliści, którzy - często nie wiedząc o sobie nawzajem znają koncepcję Rity Charon i sięgają do niej w prowadzonych przez siebie badaniach. Okazało się także, że w wielu miejscach na świecie (m.in. w USA, Kanadzie i Szwecji) polscy lekarze (klinicyści polskiego pochodzenia) pracują z wykorzystaniem medycyny narracyjnej, zaszczepiają i rozwijają tę ideę.

Artykuły zebrane $\mathrm{w}$ niniejszej monografii ukazują medycynę narracyjną $z$ dwóch podstawowych perspektyw. Pierwszą z nich jest praktyka medyczna, rozszerzona o aspekt dydaktyczny, dotyczący kształcenia umiejętności komunikacyjnych oraz postawy etycznej studentów kierunków medycznych. Drugą zaś jest współczesna humanistyka, przechodząca dostrzegalny „zwrot ku narracji”: podejście narracyjne w medycynie osadzone zostaje $\mathrm{w}$ ramach badań filologicznych, literaturoznawczo-językoznawczych. Warto podkreślić, że prezentowane artykuły zostały napisane przez autorów o różnorodnym ukierunkowaniu zawodowym i naukowym. Osoby związane z pracą kliniczną otrzymują w postaci medycyny narracyjnej narzędzie, dzięki któremu mogą docierać do głęboko humanistycznego wymiaru swojej profesji; dla nich interpretowanie opowieści pacjentów jest doświadczeniem nowym w stosunku do tego, czym zajmują się w codziennej praktyce. Z kolei dla filologów, literaturoznawców i językoznawców, analiza i interpretacja tekstu, docieranie do zawartych w nim pokładów treści są istotą pracy badawczej. W tych artykułach, oprócz wnikliwych analiz, inspirujących - w co wierzę - także dla odbiorców związanych z medycyną, znajdują się różnorodne odniesienia do zagadnień medycznych (dotyczących zdrowia, choroby, praktyki klinicznej, relacji między lekarzem i pacjentem), ukazanych przez pryzmat dyscyplin filologicznych. Są w tych pracach fragmenty sięgające do źródeł medycyny narracyjnej oraz jej podstaw metodologicznych.

Oddawana do rąk Czytelników książka jest publikacją interdyscyplinarną. Takie podejście jest uzasadnione specyfiką podjętej tematyki. W medycynie narracyjnej przenikają się odniesienia do kilku dziedzin humanistyki. W sposób szczególny łączy ona medycynę i literaturę (a raczej: literaturoznawstwo), czyli dwie profesje i pasje Rity Charon, 
twórczyni koncepcji². We wprowadzeniu do książki Narrative Medicine: Honoring the Stories of Illness Charon przyznaje, że medycyna narracyjna wyłoniła się z kilku źródeł. Określa tę dziedzinę jako „kliniczną kuzynkę badań nad związkami literatury i medycyny oraz literacką kuzynkę opieki skoncentrowanej na relacji"

Wokół medycyny narracyjnej powstało wiele nieporozumień, także $\mathrm{w}$ środowisku medycznym. Wynikają one $z$ kilku powodów, m.in. z niedostatecznego zrozumienia istoty tej koncepcji, zwłaszcza relacji między medycyną a narracją (jak połączyć ze sobą opowieści pacjentów, literaturę i opiekę medyczną opartą na dowodach?), oraz z braku jednoznaczności samego terminu narrative medicine i jego tłumaczeń ${ }^{4}$. Aby właściwie pojąć i zaprezentować istotę medycyny narracyjnej - zgodnie $z$ intencjami i w duchu profesor Charon - należy podkreślić, że nie każda obecność narracji w medycynie, nie każda opowieść o doświadczeniu choroby (czy to wyrażona $\mathrm{w}$ formie literackiej, czy jako wypowiedź mieszcząca się w ramach dyskursu medycznego) jest medycyną narracyjną. Medycyna narracyjna, w kształcie zaproponowanym przez Ritę Charon i jej współpracowników, jest konkretną, przemyślaną i dokładnie opisaną w literaturze przedmiotu formą praktyki klinicznej (i dydaktycznej), która wspiera proces diagnozy i leczenia. Jest to model sprawowania opieki nad pacjentem, akcentujący jego podmiotowość, dowartościowujący jego perspektywę i osobiste doświadczenie choroby. Polega na uważnym obserwowaniu chorego, słuchaniu i interpretowaniu wysyłanych przez niego komunikatów (werbalnych i niewerbalnych) i wyprowadzaniu na tej podstawie wniosków klinicznych, uzupełniających "twarde” dane fizyczne. Tę specyfikę koncepcji Charon oddaje opisowe sformułowanie Narrative Evidence-Based

${ }^{2}$ Rita Charon ukończyła studia medyczne na Harvard Medical School w 1978 roku, w szpitalu Montefiore w Nowym Jorku zrobiła specjalizację z medycyny wewnętrznej. Po kilku latach praktyki klinicznej rozpoczęła studia literaturoznawcze na Uniwersytecie Columbia. Studiowała literaturę amerykańską i porównawczą, w 1999 roku obroniła doktorat na temat twórczości Henry'ego Jamesa. Jej praca doktorska nosiła tytuł: The Great Beheld Sum of Things: Intersubjective Studies of Henry James, Literary Studies of Medicine i dotyczyła możliwości wykorzystania literatury, w tym teorii narracji, w pracy klinicznej, w relacji z pacjentem.

${ }^{3}$ Rita Charon, Narrative Medicine: Honoring the Stories of Illness, New York 2006, s. vii. Wszędzie, gdzie nie podano inaczej, przekładu cytatów dokonały autorki danych tekstów.

${ }^{4}$ Por. uwagi na temat terminu "medycyna narracyjna” w artykule Medycyna narracyjna $z$ perspektywy lingwistyki $i$ poetyki kognitywnej w tej książce. 
Medicine, nawiązujące do zakorzenionego w myśli medycznej wyrażenia Evidence-Based Medicine. Medycyna narracyjna to także propozycja szkolenia studentów i pracowników opieki medycznej, przygotowująca ich do pracy z pacjentami poprzez kształtowanie określonych umiejętności, w tym kompetencji narracyjnej. Służą temu m.in. czytanie tekstów literackich, kontakt $z$ dziełami malarskimi i filmowymi, ich wielopoziomowa analiza i interpretacja.

W niniejszym tomie znajdują się artykuły dotyczące bezpośrednio medycyny narracyjnej, skupione na określonych jej aspektach (teoretycznych i praktycznych); takie, dla których podejście narracyjne stanowi inspirację, tło bądź punkt wyjścia do szerszej refleksji, a także takie, które dotyczą pokrewnych relacji literatury i medycyny. Zostały one podzielone na cztery części.

Na część pierwszą składają się teksty skupione wokół roli medycyny narracyjnej w praktyce klinicznej i w dydaktyce medycznej. Otwiera ją artykuł Małgorzaty Luber-Szumniak, lekarki z wieloletnim doświadczeniem klinicznym, która zarysowuje perspektywę zagraniczną omawianej koncepcji: opowiada historię rozwoju medycyny narracyjnej w Szwecji. Dwa następne teksty to studia narracji kobiet. Barbara Baranowska, Antonina Doroszewska i Urszula Tataj-Puzyna poruszają kwestie naturalnej obecności narracji w położnictwie i opowieści kobiet na temat doświadczeń (tych dobrych, i tych złych) związanych z ciążą, porodem i macierzyństwem. Narracje kobiet z niepełnosprawnościami, jako źródło wiedzy i czynnik kształtujący wrażliwość personelu medycznego, opisują Halina Kulik i Józefa Dąbek.

W części drugiej zawarte są artykuły podejmujące wybrane aspekty metodologiczne medycyny narracyjnej. Artykuł Marty Chojnackiej-Kuraś pokazuje podstawowe założenia teoretyczne medycyny narracyjnej z perspektywy lingwistyki i poetyki kognitywnej. Literaturoznawczyni Hanna Serkowska koncentruje uwagę na stworzonej przez Ritę Charon metodzie „równoległych kart choroby”. Omawia ją na przykładzie opisywanych przez lekarzy historii pacjentów, które składają się na cykl Die ene patiënt ukazujący się w weekendowym dodatku do holenderskiego dziennika „De Volkskrant”. Artykuł autorstwa Aleksandry Szugajew przybliża odbiorcom, na konkretnym przykładzie literackim, podstawową metodę pracy $z$ tekstem, stosowaną na szkoleniach i warsztatach z medycyny narracyjnej.

Trzecią część tomu tworzą teksty dotyczące narracji w dyskursie medycznym i w komunikacji między lekarzem a pacjentem. Tematem lingwistycznego artykułu Magdaleny Zabielskiej i Magdy Żelazowskiej- 
-Sobczyk są fachowe publikacje medyczne, w których uwzględnia się relacje przekazywane przez lekarzy i pacjentów jako istotne źródło wiedzy klinicznej. Tekst Anny Kuzio dotyczy interakcji między lekarzami i pacjentami; autorka bada wpływ ram grzecznościowych oraz strategii narracyjnych na spójność i skuteczność komunikacji.

W ostatniej, czwartej części zebrane zostały teksty, które można nazwać - przywołując metaforyczny koncept Rity Charon - „literackimi kuzynkami" medycyny narracyjnej. Artykuły te pokazują różne relacje między literaturą a medycyną. Pierwszy z nich należy do nurtu badań nad literaturą podejmującą problematykę przeżywania choroby. Literaturoznawczyni Monika Ładoń przedstawia wnikliwe studium narracji o traumatycznym doświadczeniu choroby we wspomnieniowej książce Eve Ensler $W$ trzewiach świata. Wspomnienia. Drugi artykuł łączy w sobie literaturę z logopedią i lingwistyką kliniczną. Olga Osińska analizuje w nim twórczość Leo Lipskiego, pisarza dotkniętego afazją. Uwzględniając współczesną wiedzę z zakresu logopedii, pokazuje cechy językowe utworów Lipskiego, w których można dostrzec typowe dla afazji objawy „rozpadu języka”. Zamykający publikację tekst Agnieszki Więckiewicz dotyczy koncepcji wzajemnej analizy Sándora Ferencziego, węgierskiego psychoanalityka, którego myśli na temat relacji lekarza z pacjentami pod wieloma względami są zbieżne z podstawowymi założeniami i praktyką medycyny narracyjnej.

Zapraszam do lektury z nadzieją, że każdemu z Czytelników książka ta przyniesie coś dobrego, że pozwoli zrozumieć koncepcję medycyny narracyjnej i wypracować własne zdanie na jej temat.

Serdecznie dziękuję wszystkim, którzy przyczynili się do powstania tej monografii, szczególnie: Autorkom - za pasję i przygotowanie tekstów, Recenzentom - za uważną lekturę i konstruktywne uwagi. Wyrazy wdzięczności za nieustające wsparcie i współpracę składam Doktor Antoninie Doroszewskiej i Doktor Aldonie Katarzynie Jankowskiej.

Marta Chojnacka-Kuraś

\section{Bibliografia}

Charon R., Narrative Medicine: Honoring the Stories of Illness, Oxford University Press, New York 2006. 


\section{MEDYCYNA NARRACYJNA W PRAKTYCE KLINICZNEJ I DYDAKTYCE MEDYCZNEJ}


Małgorzata Luber-Szumniak

Szpital Uniwersytecki Skania w Lund

\section{Medycyna narracyjna w Szwecji}

W niniejszym artykule, pisanym z perspektywy lekarki od wielu lat pracującej z pacjentami w przychodni i w szpitalu w Lund, chciałabym opowiedzieć o początkach i rozwoju koncepcji medycyny narracyjnej w Szwecji. Witryna internetowa Szwedzkiego Związku Medycyny Narracyjnej otwiera się mottem „Każdy człowiek to opowieść”. Pozwolę sobie rozpoczać od zacytowania wiersza, który rozwija tę myśl. Autorem Krótkiej pauzy w koncercie organowym (utworu pochodzącego z tomu Wiersze i proza 1954-2004, w przekładzie Leonarda Neugera) jest Tomas Tranströmer, szwedzki poeta, tłumacz i psycholog, uhonorowany w 2011 roku Nagrodą Nobla w dziedzinie literatury.

[...] każdemu przypisana jest własna encyklopedia, wyrasta w każdej duszy, pisana od narodzin, setki tysięcy wciśniętych w siebie stron,

a między nimi jednak jest powietrze! jak drgające liście w lesie.

Księga sprzeczności.

To, co w niej napisane, zmienia się w każdej chwili, obrazy

Retuszują się same, słowa migoczą.

Fala toczy się przez cały tekst, a za nią następna fala i następna... ${ }^{1}$

Sztuka i humanistyka zmagają się z tajemnicą człowieczeństwa. Tajemnica, przed którą stajemy za każdym razem, gdy ktoś cierpi na ciężką chorobę, zwłaszcza w fazie paliatywnej, w starciu z nieuchronną

${ }^{1}$ Tomas Tranströmer, Wiersze i proza 1954-2004, przeł. L. Neuger, Kraków 2012, s. 268-269. 
śmiercią. Problemy egzystencjalne, które napotykamy w pracy klinicznej, wymagają zadumy i refleksji. Teksty literackie, $w$ tym poezja, oraz obrazy i filmy mogą być dla nas narzędziami wspomagającymi rozwój empatii oraz zdolności narracyjnych. Oczywiście, rozmowy o chorobie muszą obejmować obiektywne osiągnięcia współczesnej medycyny, ale w szerszej perspektywie literatura i sztuka przyczyniają się do pełniejszego zrozumienia chorego postawionego przed zagadką istnienia. Medycyna narracyjna może zapewnić dogłębną wiedzę o pacjencie, ale także o nas samych jako lekarzach i ludziach. Zapisując myśli i refleksje dotyczące spotkania z pacjentem, możemy zastanowić się nad sobą i uświadomić sobie głębsze znaczenie naszej codziennej pracy. Podobnie czytanie poezji obcowanie $z$ tekstem poetyckim pobudza nas do myślenia i wnikania w jego treść, a to może wzbogacać nas w klinicznej pracy z pacjentami, stymulować nasze zaangażowanie $\mathrm{w}$ pomaganie ludziom i pragnienie czynienia dobra.

Początek zainteresowania medycyną narracyjną w Szwecji można datować na rok 2000, kiedy to w szwedzkim odpowiedniku „Gazety Lekarskiej” (szw. „Läkartidningen”) ukazał się artykuł Medycyna narracyjna - opowieść $o$ pacjencie $i$ jego chorobie ${ }^{2}$. W tekście, który wzbudził spore zainteresowanie nie tylko w środowisku medycznym, podjęto próbę zbadania różnych znaczeń terminu narrative medicine i przedstawiono przegląd aktualnej literatury z tej dziedziny. Autorem publikacji był Fredrik Svenaeus - filozof, profesor teorii wiedzy stosowanej w Centrum Wiedzy Praktycznej na Uniwersytecie Södertörn w Sztokholmie ${ }^{3}$. Streszczenie artykułu i wnioski, jakie $\mathrm{z}$ niego płyną, można ująć $\mathrm{w}$ kilku punktach.

- Strukturę interpretacji (ułatwiającą dialog medyczny) można lepiej zrozumieć dzięki zastosowaniu teorii filozoficznych Hansa-Georga Gadamera i Paula Ricoeura, których koncepcje, takie jak: świat życia,

${ }^{2}$ Fredrik Svenaeus, Narrativ medicin: berättelsen om patienten och hennes sjukdom, „Läkartidningen” 2000, s. 3629-3632.

${ }^{3}$ Główne obszary badań naukowych Fredrika Svenaeusa to: filozofia medycyny, bioetyka, humanistyka medyczna i antropologia filozoficzna. Prowadzi on wykłady na temat wpływu współczesnej medycyny i technologii na społeczeństwo oraz na ludzką percepcję i etykę; opublikował wiele naukowych i popularnonaukowych artykułów i książek, m.in.: Hermeneutyka medycyny i fenomenologia zdrowia (1999), Znaczenie choroby (2003), Homo Patologicus - medyczne diagnozy naszych czasów (2013) czy Fenomenologiczna bioetyka: technologie medyczne, ludzkie cierpienie $i$ znaczenie bycia żywym (2017). 
horyzont rozumienia i życie jako opowieść, podkreślają kluczowe elementy praktyki lekarskiej.

- Element narracyjny może odgrywać znaczącą rolę również w etyce medycznej, ponieważ pozwala przedstawić szerszy obraz danej sytuacji, uwzględniający różne punkty widzenia na temat trudnych moralnie sytuacji klinicznych.

- Niezależnie od tego, czy wybierze się szerszą, czy też bardziej restrykcyjną interpretację pojęcia tekstu, praktyka medyczna może być traktowana jako działalność hermeneutyczna (oparta na interpretacji), kiedy to lekarz $\mathrm{w}$ dialogu $\mathrm{z}$ pacjentem próbuje mu jak najlepiej pomóc.

Kontynuacją tematu medycyny narracyjnej w Szwecji było ukazanie się w 2011 roku w „Krytycznym Forum Teologii Praktycznej” (szw. „Kritisk Forum for Praktisk Teologi") artykułu Ciało choroby: narracja, cielesność $i$ relatywność $w$ praktyce lekarskiej i pielegniarskiej ${ }^{4}$. Autor, Ola Sigurdson, teolog, profesor filozofii religii i nauk o życiu na Wydziale Literatury, Historii Idei i Religii na Uniwersytecie w Göteborgu, podjął w swojej publikacji próbę krytycznej analizy wymienionych w tytule zjawisk z perspektywy filozofii współczesnej, historii idei i humanistyki medycznej. Powiązania te starał się wyjaśnić na przykładzie karty historii choroby pacjenta. Kartę tę przedstawił nie tylko jako narzędzie diagnostyczne, które prezentuje fakty medyczne, lecz także jako coś, co określa rodzaj postawy, jaką lekarz lub pielęgniarka przyjmuje w stosunku do chorego, a tym samym - rodzaj ucieleśnienia, jaki staje się przedmiotem badania fizykalnego. Sigurdson zaznacza, że słowa mają swoje znaczenie także w kartotece pacjenta, a sposób, w jaki chory jest opisywany, odzwierciedla podejście personelu medycznego do pacjenta. A zatem różne metody tworzenia historii choroby wyrażają różne postawy wobec pacjenta i to, w jaki sposób rozumie się jego fizyczność.

Ola Sigurdson odwołuje się w swoim tekście do Rity Charon i jej książki Narrative Medicine: Honoring the Stories of Illness z 2006 roku. Z publikacji tej wybiera m.in. następujące cytaty: „Diagnoza sama w sobie jest próbą narzucenia fabuły na pozornie niepowiązane wydarzenia lub zastany

${ }^{4}$ Ola Sigurdson, Sjukdomens kropp: Narrativitet, kroppslighet och relationalitet $i$ medicinsk praktik och omvårdnad, „Kritisk Forum for Praktisk Teologi” 2011, s. 6-22. 
stan rzeczy” ${ }^{5}$ oraz „Studia literackie dają medycynie świadomość, że nasze relacje medyczne wyłaniają się w słowach" ${ }^{6}$. Przykładami podobnego spojrzenia na praktykę medyczną są m.in. dwie książki: How Doctors Think Jerome'a Groopmana ${ }^{7}$ z 2007 roku oraz opublikowana w 2009 roku Every Patient Tells a Story: Medical Mysteries and the Art of Diagnosis Lisy Sanders ${ }^{8}$.

W kontekście rozważań nad życiem człowieka jako opowieści warto przywołać postać Clarence’a Crafoorda. Jest to znany szwedzki psychiatra, psychoanalityk i pisarz, pionier szwedzkiej psychiatrii od lat 70., a przez ostatnie dwadzieścia lat także autor książek psychologicznych i opowieści o literaturze oraz o własnych doświadczeniach jako czytelnika i uważnego obserwatora ludzi i zdarzeń. We wstępie do swojej książki Człowiek to opowieść: myśli o sztuce rozmowy Crafoord pisze tak:

Rozmawiać to coś więcej niż tylko wymieniać się słowami. To znaczy widzieć i słyszeć wszystkimi zmysłami, i być świadomym, że będąc słuchaczem, jest się też jednocześnie narratorem. Nasze istotne wspomnienia charakteryzują nas od pierwszej chwili i są przywoływane zarówno w ciele, jak i w umyśle. Są one prezentowane przez całą naszą istotę. Kiedy dostrzegamy tę wbudowaną historię, tworzymy perspektywę narracyjną człowieka. Człowiek to opowieść, historia, w której pojawiają się nowe rozdziały, aż do śmierci, rozdziały, które nierzadko rzucają światło na te poprzednie... Każda istota ludzka nieustannie opowiada swoją historię, nie tylko w formie ustnej, lecz także w całym swoim jestestwie - w wyglądzie, ubiorze, percepcji, postawie, głosie i chodzie ${ }^{9}$.

Wróćmy na chwilę do publikacji Sigurdsona i Charon. Według amerykańskiej lekarki medycyna ma bezspornie charakter narracyjny, dlatego że stara się opowiedzieć historię o tym, jak pacjent zachorował, na jaki rodzaj choroby, jak to doświadczenie na niego wpłynęło, jaki stopień powrotu do zdrowia jest możliwy i w jaki sposób można to osiągnąć. Jest także szersza perspektywa: ogólnie pojętą opiekę medyczną można by zanalizować jako powieść $\mathrm{z}$ intrygą, która ujawnia się w karcie choroby

${ }^{5}$ Rita Charon, Narrative Medicine: Honoring the Stories of Illness, New York 2006, s. 50 .

${ }^{6}$ Ibidem, s. 53.

${ }^{7}$ Jerome Groopman, How Doctors Think, Boston-New York 2007.

${ }^{8}$ Lisa Sanders, Every Patient Tells a Story: Medical Mysteries and the Art of Diagnosis, New York 2009.

${ }^{9}$ Clarence Crafoord, Människan är en berättelse: tankar om samtalskonst, Stockholm 1994, s. 16. 
pacjenta, a ta sama w sobie jest rodzajem gatunku literackiego, chociaż różni się od innych rodzajów literatury tym, że jej pierwotny cel jest raczej opisowy niż refleksyjny. Głównym celem tworzenia historii choroby jest uformowanie pewnej struktury - na podstawie wyników badań klinicznych, obserwacji lekarza, pielęgniarki i podsumowania własnego cierpienia przez pacjenta; takiej konstrukcji, która sprawia, że stan pacjenta staje się zrozumiały dla personelu medycznego i można rozpocząć odpowiednie leczenie. Odwołując się do wspomnianego wcześniej Groopmana, można stwierdzić, że diagnoza medyczna jest, innymi słowy, aktem odtwórczym i tak jak każda dobra powieść pozwala na wiele interpretacji, również stan pacjenta może być odczytywany na różne sposoby. Sigurdson opisał w swoim artykule przykład praktycznego zastosowania idei medycyny narracyjnej Charon. Jest nim innowacyjny projekt zmiany systemu obchodów lekarskich, zainicjowany w 2008 roku w szpitalu w Kungälv (położonym na północ od Göteborga) i po długich dyskusjach oraz cyklach testowych wprowadzony tamże w 2010 roku. Jest to tzw. inny obchód, model oparty na pracy zespołowej i przykład sposobu prowadzenia praktyki klinicznej według idei służby zdrowia zorientowanej na osobę pacjenta (ang. person-centered care), gdzie stwarza się miejsce, czas i przestrzeń na opowieść chorego.

Model opieki zdrowotnej ukierunkowanej na pacjenta jako indywidualną jednostkę wyraźnie różni się od tradycyjnego modelu leczenia, w którym postrzega się pacjenta jako pasywnego odbiorcę interwencji medycznej: pracownicy służby zdrowia, udzielając pacjentom zaleceń medycznych, zwyczajowo koncentrują się na objawach i dysfunkcjach, a nie na rezerwach witalnych chorego nieodzownych do jego wyzdrowienia. Model opieki zdrowotnej ukierunkowanej na pacjenta jest sposobem myślenia i postrzegania odbiorców usług medycznych jako równorzędnych partnerów w planowaniu, rozwijaniu i monitorowaniu opieki zdrowotnej zaspokajającej ich potrzeby. Oznacza to umieszczenie pacjenta i jego rodziny $\mathrm{w}$ centrum podejmowania decyzji i traktowanie go jako eksperta od własnego stanu zdrowia, współpracującego z profesjonalistami w celu uzyskania jak najlepszych wyników leczenia. Nie jest to jednak równoznaczne z zaspokajaniem dowolnych potrzeb pacjentów; chodzi raczej o uwzględnianie indywidualnych ludzkich pragnień i wartości, sytuacji rodzinnej, warunków społecznych i stylu życia danego pacjenta, aby pomóc mu w zarządzaniu jego zdrowiem i wspólnie wypracować odpowiednie dla niego rozwiązania zdrowotne. Partnerstwo pomiędzy 
pracownikami służby zdrowia, pacjentem i jego krewnymi, mające punkt wyjścia w historii medycznej chorego, optymalizuje cele i strategie monitorowania jego zdrowia, zarówno krótko-, jak i długoterminowe. Pacjent, jako niezależna i zdolna do podejmowania świadomych decyzji osoba, jest bardziej zaangażowany $\mathrm{w}$ proces diagnostyczno-leczniczy i ma większe możliwości ponoszenia odpowiedzialności za własne zdrowie, leczenie i rehabilitację. Jest to obecnie uznawane za priorytet i kluczowy element rozwoju wysokiej jakości opieki zdrowotnej.

Problem z obecnie obowiązującym m.in. w Szwecji systemem prowadzenia i dokumentowania historii choroby pacjenta sprowadza się do różnych oczekiwań w stosunku do lekarzy i pielęgniarek. Od lekarzy zwykle oczekuje się monitorowania ściśle medycznej historii danego pacjenta i tego, co inni lekarze napisali o nim wcześniej w kartotece, podczas gdy od pielęgniarek wymaga się opieki pielęgnacyjnej. Efekt jest taki, że wyniki badania fizykalnego czy radiologicznego oraz rezultaty różnych testów oddzielane są od ogólniejszej perspektywy choroby, historii życiowej pacjenta i opisu stylu życia, który wpływa na jego zdrowie. Jeśli to ma stanowić podstawę do planowania opieki, to taki system wiąże się z ryzykiem, że ważne aspekty zdrowia pacjenta zostaną pominięte, znajdą się $\mathrm{w}$ luce między tym, co definiują lekarze, a tym, co określa się jako szeroko pojęte pielęgniarstwo. W szpitalu w Kungälv personel opisywał to zjawisko jako „oddzielenie ciała od umysłu”: podczas gdy lekarze zajmują się ciałem jako obiektem badanym przez nauki medyczne, pielęgniarki opiekują się umysłem - w znaczeniu osobistych i społecznych aspektów ludzkiej egzystencji.

Zmiana historycznie utrwalonej instytucji, jaką jest typowa wizyta lekarska na oddziale, była dla pracowników szwedzkiego szpitala wyzwaniem. Nad projektem alternatywnego modelu wizyty lekarskiej pracował interdyscyplinarny zespół (złożony z lekarzy, pielęgniarek, farmaceutów, terapeutów) pod kierunkiem Valdemara Erlinga, hematologa, ordynatora w Klinice Internistycznej szpitala w Kungälv. Ten nowatorski model miał zmniejszać różnice i ułatwiać współpracę między przedstawicielami różnych profesji w zespole leczącym. Członkowie zespołu postawili sobie kilka zasadniczych pytań: „Dlaczego w ogóle wykonujemy obchody i dla kogo to robimy?”, „Co nas motywuje do opieki nad pacjentem?”, „W jaki sposób codzienne spotkanie z pacjentem może stworzyć trwałe wartości dla pacjentów i dla pracowników szpitala?”, „Czy potencjał, jaki powstaje pomiędzy pacjentem a pracownikiem służby zdrowia podczas 
wartościowego spotkania, promuje nasze wysiłki na rzecz poprawy jakości opieki zdrowotnej?".

Grupa inicjatorów nowej koncepcji, nazwana Ward Round Developing Group (w składzie: dwie asystujące pielęgniarki, dwie pielęgniarki, jeden lekarz rezydent, jeden lekarz specjalista i kierownik projektu, a rok później także przedstawiciel pacjentów jako stały członek grupy projektowej), przeprowadziła wśród personelu oddziału internistycznego badanie pilotażowe, mające na celu stworzenie funkcjonalnego, zgranego zespołu interdyscyplinarnego i zaangażowanie wszystkich zainteresowanych stron we wspólne działanie. Kierownictwo kliniki wspierało tę inicjatywę jako komitet zarządzający. Punktem wyjścia do zmian była obserwacja, że istnieje tendencja do sprowadzania pacjenta leżącego w lóżku szpitalnym, zwłaszcza w wieloosobowej sali, do roli badanego obiektu i opisywania go instrumentalnie, np. tak: „Zapalenie wyrostka robaczkowego pod czwórką (nr sali) na dwójce (nr łóżka)". Pacjent leżący w łóżku szpitalnym wygląda na bardziej chorego, a nawet czuje się poważniej chory, niż wskazywałby na to rzeczywisty stan jego zdrowia. Pacjent, który wstanie z łóżka i może spotkać się z całym zespołem leczącym na siedząco, czuje, że jest na równorzędnym poziomie z rozmówcami. Wszyscy zaangażowani w proces diagnozowania i leczenia słuchają jednocześnie historii pacjenta; przy takiej wspólnej obserwacji chorego przez wszystkich członków zespołu można łatwiej ocenić medycznie pacjenta (np. stan jego sprawności fizycznej czy stopień niewydolności serca według klasyfikacji funkcjonalnej NYHA).

Dzięki takiej ścisłej współpracy zespół uczy się rozumieć swoje różne umiejętności i obowiązki, bieżąca komunikacja ułatwia też budowanie grupy oraz wzajemne podnoszenie kwalifikacji. Harmonogramy pracy lekarzy i pielęgniarek zaczęto układać równolegle w stosunku do tygodnia pracy, bowiem zaobserwowano, że brak ciągłości opieki utrudnia odpowiedzialność i wydłuża czas hospitalizacji pacjenta. Jedna z głównych zasad organizacji takiej pracy zespołowej brzmi: „jeden pacjent na raz", co oznacza wykonanie i ukończenie wszystkich prac dotyczących danego pacjenta podczas wspólnej konsultacji w pokoju badań. Kiedyś dokumentacja medyczna wykonywana była osobno przez lekarza i pielęgniarkę, teraz robi się to razem. Pracownicy szpitala w Kungälv uważają, że tak dokładne pierwsze spotkanie $z$ pacjentem, $z$ obopólnym poczuciem obecności, zaangażowania i wystarczającej ilości czasu, ma wpływ na cały pobyt chorego na oddziale. Plan badań, leczenia i zakres opieki 
po wypisie ustala się razem z pacjentem, który jest też informowany, że podobne spotkania będą się odbywać w razie potrzeby, jednak niekoniecznie codziennie. Do współpracy zaprasza się także rodzinę pacjenta i lekarza podstawowej opieki zdrowotnej; dzięki wykorzystaniu technologii wirtualnej można taką grupową naradę przeprowadzić online. Ten sposób wizytowania chorych chroni integralność pacjenta i daje mu szansę wzięcia aktywnego udziału we własnym leczeniu, okazuje się skuteczniejszy niż tradycyjny model i zapewnia całościowo lepszą opiekę medyczną.

Można sobie zadać pytanie: czy każdy chory w szpitalu jest gotowy „Wziąć swoje łóżko i iść”? Po podsumowaniu dziesięcioletniego doświadczenia takiego sposobu praktyki klinicznej okazało się, że około 80\% pacjentów na oddziałach w szpitalu w Kungälv nie odczuwało problemów z przemieszczeniem się do pokoju badań i pozytywnie oceniało możliwość opuszczenia swojego łóżka. Badania wykazują, że aktywacja poza łóżkiem szpitalnym - z wyjątkiem bardzo chorych pacjentów - sprzyja szybszej poprawie stanu zdrowia. Taki sposób pracy zapewnia także poufność, zgodnie ze szwedzkimi prawami pacjenta, gwarantuje pacjentowi autonomię, zwiększa świadomość etyczną personelu i poprawia zdolność do podejmowania etycznie uzasadnionych decyzji medycznych. Pielęgniarki, lekarze i cały zespół leczący, pracujący w ten sposób, opisują poprawę oferowanej opieki zdrowotnej, zwracają uwagę na to, że ich praca przebiega szybciej i płynniej, czują się bardziej zadowoleni z jej jakości i doświadczają większej satysfakcji oraz bliższych relacji z pacjentami. Mimo że taka struktura nie jest optymalna dla wszystkich oddziałów w lecznictwie zamkniętym, to jednak implikuje nowy sposób myślenia. Rozpowszechniła się w innych szwedzkich szpitalach, a także wzbudziła zainteresowanie $\mathrm{w}$ innych krajach europejskich.

Całokształt pracy nad tym nowatorskim systemem i wprowadzenie go w życie zostały docenione i wyróżnione przez Szwedzkie Towarzystwo Lekarskie w 2015 roku. Wtedy to przyznano nagrodę Hipokratesa (wyróżnienie w dziedzinie etyki) właśnie Valdemarowi Erlingowi z Kungälv za jego rzetelną pracę nad etyką, zwłaszcza tą stosowaną w codziennej pracy klinicznej. Uzasadnienie przyznania nagrody brzmiało następująco:

Opieka zdrowotna została podniesiona na wyższy poziom dzięki wprowadzeniu nowego systemu obchodów lekarskich polegającego na tym, że to pacjent indywidualnie spotyka się z całą grupą leczącą $\mathrm{w}$ osobnym pokoju i tam omawia się jego swoiste diagnozowanie i leczenie. Ten pionierski system 
ułatwia aktywną codzienną pracę nad podstawowymi kwestiami etycznymi, takimi jak prywatność, poufność, integralność i współuczestniczenie w procesie leczenia ${ }^{10}$.

Szwedzka innowacja została też zauważona przez samą Ritę Charon, która tak oto opisuje ją w najnowszej książce Principles and Practice of Narrative Medicine:

Unikalny i inspirujący eksperyment $\mathrm{w}$ rozwoju narracyjnego zespołu opieki zdrowotnej ma miejsce w Göteborgu, w Szwecji, i włączamy go tutaj jako przykład konsekwencji pełnej narracji świadomości w zakresie rozwoju zespołu leczącego w głównych instytucjach opieki zdrowotnej. Zainspirowani koncepcjami medycyny narracyjnej i opieki zdrowotnej zorientowanej na osobę pacjenta, pielęgniarki, asystujące pielęgniarki i lekarze zainicjowali ukierunkowany na pacjenta i oparty na pracy zespołowej system wizyt oddziałowych ${ }^{11}$.

Rodzi się pytanie: jak to się stało, że Rita Charon, światowej sławy profesor medycyny i literaturoznawczyni, twórczyni pojęcia narrative medicine i dyrektor wykonawczy programu "Narrative Medicine” na Uniwersytecie Columbia w Nowym Jorku, dowiedziała się o przedsięwzięciu z niewielkiego miasta Kungälv, mało znanym nawet w Szwecji? Otóż w 2011 roku Valdemar Erling wziął udział w kongresie hematologicznym w Nowym Jorku. Zainspirowany pracami Fredrika Svenaeusa i Oli Sigurdsona oraz samą ideą medycyny narracyjnej, nawiązał kontakt z Charon, opowiedział jej o projekcie w Kungälv i zaprosił ją do Szwecji. Kilka lat później, w 2016 roku, udało się zorganizować międzynarodową konferencję $^{12}$ w Sztokholmie oraz warsztaty w szpitalu w Kungälv, oba wydarzenia $z$ udziałem Rity Charon.

Z inicjatywy grupy zaangażowanych entuzjastów medycyny narracyjnej, głównie uczestników konferencji i warsztatu w 2016 roku, zawiązało się

${ }^{10}$ Jest to opinia wyrażona przez profesora Ingemara Engströma, eksperta w dziedzinie etyki medycznej i przewodniczącego delegacji ds. etyki medycznej Szwedzkiego Stowarzyszenia Medycznego oraz członka komitetu, który wybiera laureatów nagrody.

${ }^{11}$ Rita Charon i in., The Principles and Practice of Narrative Medicine, New York 2017, s. 300.

${ }^{12}$ Współorganizatorami konferencji byli: Valdemar Erling (z Kungälv), Lars Midbøe (ze Sztokholmu, reprezentujący SKL, organizację skupiającą szwedzkie gminy i rady powiatowe), Sahlgrenska Akademin (wydział medyczny Uniwersytetu w Göteborgu), Karolinska Institutet (szwedzka państwowa uczelnia medyczna w Sztokholmie) oraz Columbia University (Nowy Jork). 
Szwedzkie Stowarzyszenie Medycyny Narracyjnej, którego spotkanie inauguracyjne miało miejsce w styczniu 2017 roku. „To właśnie jest wasza opowieść" - zwięźle wyraziła się Charon na wiadomość o tym wydarzeniu. Zapytana, na co szczególnie powinniśmy zwrócić uwagę w działalności związku, zaproponowała skupienie się na słowach Williama Oslera (kanadyjskiego lekarza, pedagoga, filozofa medycyny i historyka, żyjącego na przełomie XIX i XX wieku): Listen to your patient; he is telling you the diagnosis („Posłuchaj swojego pacjenta; on przedstawia ci diagnozę"). Opowieść pacjenta jest bowiem kluczem do jego poznania i do dalszej wspólnej podróży w kierunku dobrej opieki zdrowotnej; pozwala lekarzom i pielęgniarkom zobaczyć tę wyjątkową osobę stojącą poza samą chorobą i prowadzi ich we właściwym kierunku: $\mathrm{ku}$ trafnej diagnozie.

Nowo powstałe stowarzyszenie mogło rozwinąć swoją działalność dzięki dotacji ze szwedzkiego ministerstwa zdrowia. Utworzono witrynę internetową, grupę na Facebooku, której członkowie aktywnie dyskutują i dzielą się interesującymi linkami, zaczęto organizować (na wzór modelu z Columbia University) comiesięczne tzw. rundy narracyjne. Są na nie zapraszani pisarze, poeci, artyści, lekarze, a po wykładzie (np. na temat utworów poetyckich o demencji, problemu wypalenia zawodowego u pracowników służby zdrowia czy praktykowania uważności w kontekście konsultacji medycznej) odbywa się wspólna dyskusja z uczestnikami spotkania. Stowarzyszenie bierze też czynny udział w konferencjach naukowych, organizuje kursy z medycyny narracyjnej i metod narracyjnych $\mathrm{w}$ różnych częściach Szwecji oraz już coroczne jesienne warsztaty w szpitalu w Kungälv. W 2017 roku głównym wykładowcą podczas tych warsztatów był John Launer, lekarz rodzinny z Anglii, klinicysta i edukator o ponad trzydziestoletnim doświadczeniu w sektorze publicznym i prywatnym, człowiek o wyjątkowo szerokiej wiedzy, rozumiejący funkcjonowanie służby zdrowia i warunki skutecznego wprowadzania zmian, czynny propagator idei i praktyki medycyny narracyjnej w Wielkiej Brytanii i innych krajach europejskich. Obecnie zajmuje się on głównie prowadzeniem warsztatów i kursów pt. Conversations Inviting Change (w skrócie CIC; pol. „Rozmowy zachęcające do zmiany”). To koncepcja opierająca się na badaniach narracyjnych, teorii komunikacji i myślenia systemowego. Została pioniersko opracowana w Tavistock Clinic w Londynie właśnie przez Launera i Caroline Lindsey. Od ponad dziesięciu lat jest praktykowana w szkoleniu pracowników służby zdrowia. Model CIC opiera 
się na prostym założeniu, że wszyscy - jako pacjenci, klienci, studenci czy współpracownicy - czerpią korzyści z opowiadania historii o swoich doświadczeniach oraz umiejętnego ich wysłuchania, zinterpretowania i wykorzystania w praktyce.

Pokłosiem dotychczasowej działalności Szwedzkiego Stowarzyszenia Medycyny Narracyjnej był też specjalny projekt stworzony w Göteborgu dla lekarzy wykształconych w krajach spoza Unii Europejskiej, którzy przed podjęciem pracy w Szwecji muszą uzupełnić swoje kompetencje. Testowali oni z zawodowymi aktorami nowe narzędzia komunikacyjne przydatne w konsultacji medycznej, zwłaszcza w pracy z wymagającymi pacjentami. Aktorzy odgrywali trudne sytuacje kliniczne na podstawie autentycznych przypadków chorobowych. Idea tego typu szkoleń narodziła się spontanicznie, jesienią 2017 roku. Wtedy to profesor Henrik Sjövall, specjalista chorób wewnętrznych, wracał autobusem do domu z warsztatów w Kungälv i usiadł obok Victorii Brattström, reżyserki, aktorki i wykładowczyni w Akademii Muzyki i Dramatu, a także doktorantki w Centrum Opieki Zdrowotnej Ukierunkowanej na Pacjenta Uniwersytetu w Göteborgu (gdzie realizowała projekt, w którym badała porównawczo role i sposób podejścia do pracy w teatrze i w służbie zdrowia). Victoria i Henrik rozmawiali o tym, jak ważne jest, żeby odpowiednio uczyć przyszłych lekarzy, jak mają leczyć pacjentów we właściwy sposób, jak „odczytywać ludzi”, jak rozwiązywać trudne sytuacje i dylematy kliniczne. Może warto ćwiczyć w podobny sposób, jak robią to aktorzy przygotowujący się do nowej roli? Brattström już wcześniej była zaangażowana w medycynę narracyjną i jej powiązania ze sztuką i literaturą. Dla celów badawczych swojej pracy doktorskiej nagrywała konsultacje lekarskie, pozwalała aktorom interpretować te transkrybowane spotkania, a następnie aktorzy odtwarzali je dla pracowników służby zdrowia i pacjentów, po czym wszyscy wspólnie omawiali interpretację danej roli.

W tym miejscu chciałabym wspomnieć również o humanistyce medycznej w Szwecji i jej znaczeniu w kształceniu studentów wydziałów lekarskich. Wielu naukowców wydziałów humanistycznych w Szwecji zaangażowało się w edukację studentów medycyny. Należą do nich profesorowie literatury Merete Mazarella w Uppsali czy Anders Palm w Lund oraz profesor teologii systematycznej Ola Sigurdson w Göteborgu. Prężnym ośrodkiem humanistyki medycznej w Szwecji jest Uniwersytet w Lund, jeden $z$ najstarszych i największych uniwersytetów w Skandynawii. To między innymi Anders Palm wraz z Johanem Stenströmem zainicjowali 
w 2012 roku jedno z pierwszych sympozjów na temat humanistyki medycznej w Szwecji.

Uniwersytet $\mathrm{w}$ Lund $\mathrm{w}$ unikalny sposób przyczynił się nie tylko do rozwoju humanistyki medycznej, lecz także do kształcenia studentów wydziałów medycznych. W 2007 roku Anders Palm zainicjował kurs „Ciało w perspektywie humanistycznej”, który umożliwia studentom medycyny wykorzystanie literatury, muzyki, filmu i innych form sztuki do sproblematyzowania przyszłej roli zawodowej i doskonalenia techniki konsultacji medycznych. Dzięki sile woli Palma, jego wizjonerskiemu podejściu i zaangażowaniu w edukację studentów kurs ten został z powodzeniem włączony do regularnej edukacji medycznej na tych samych warunkach i przy takich samych wymaganiach programowych, co inne zajęcia ściśle kliniczne. W uznaniu tych zasług Palm w 2010 roku został przyjęty jako członek stowarzyszony do Szwedzkiego Towarzystwa Medycznego, a rok później otrzymał tytuł doktora honoris causa na Wydziale Lekarskim Uniwersytetu w Lund.

Po jego przejściu na emeryturę katedrę literatury objęła Katarina Bernhardsson, literaturoznawczyni i wykładowczyni w dziedzinie humanistyki medycznej w Centrum Języka i Literatury, gdzie uczy oraz opracowuje nowe sposoby wprowadzania humanistyki do programu studiów, zwłaszcza na wydziałach lekarskich. Jej praca doktorska z 2010 roku, dotycząca wizerunków chorób we współczesnej szwedzkiej prozie, oceniana była jako nie tylko stymulująca intelektualnie, lecz także trafiająca prosto do serca czytelnika. Bernhardsson prowadzi też zajęcia dydaktyczne na Wydziale Lekarskim Uniwersytetu w Lund w ramach kursu rozwoju profesjonalnego. Już w pierwszym semestrze studenci wraz z tutorami studiują literaturę i film, w ramach zajęć czytają zalecone lektury i prowadzą grupowe dyskusje. Część kursu zawiera również wiele innych elementów klinicznych - tu studenci mogą wcześnie spróbować swych sił w praktyce szpitalnej. Kurs ten stanowi ważny wgląd w zawód lekarza i jego kliniczne wyzwania, a wykorzystanie literatury i filmu działa jak swego rodzaju bank doświadczeń, dzięki któremu studenci mogą omawiać różne doświadczanie chorób z perspektywy pacjentów. Jest to istotne zwłaszcza dla nowych adeptów sztuki medycznej, jeszcze bez doświadczenia klinicznego. Kiedy studenci zdobędą już pewne doświadczenie, perspektywa humanistyczna daje im możliwość autorefleksji i trenowania empatii - tego nie umożliwia przedkliniczna edukacja teoretyczna o charakterze czysto medycznym. Na czwartym roku studiów 
w ramach kursu rozwoju profesjonalnego jest kolejny tydzień intensywnych zajęć. To jedyny obowiązkowy element kształcenia literackiego w obrębie wydziału lekarskiego. Ma on przypominać studentom o szeroko pojętej humanistyce medycznej w momencie, w którym - przepracowawszy już kilka semestrów w klinice - sami zaobserwowali, jak humanistyka może uzupełniać ich codzienną pracę. Studenci w trakcie części klinicznej seminariów dyskutują o technice konsultacji medycznej, omawiają tematy etyczne, problematykę przekazywania pacjentom trudnych wiadomości i prowadzenia opieki paliatywnej. Tu zwykle jest też miejsce na spotkanie z autentycznym pisarzem - studenci czytają wspólnie jego książkę i omawiają ją. Oprócz dyskusji na tematy literacko-medyczne przedstawiane jest również résumé z dziedziny humanistyki medycznej. Najbardziej ambitną część całego programu stanowi pięciotygodniowy kurs w pełnym wymiarze czasu zajęć, oferowany na ostatnim roku studiów. Ten kurs jest fakultatywny, konkurencyjny wobec kursów np. z ratownictwa medycznego, diagnostyki obrazowej czy zdrowia publicznego; służy nie tylko jako uzupełnienie innych seminariów i praktyk studenckich, lecz także jako refleksja nad nimi i szansa dla pewnego rodzaju kontrkultury wobec wiedzy ściśle medycznej. Jest on wybierany przez 10-15\% wszystkich studentów.

Ostatnim nawiązaniem do twórczyni koncepcji medycyny narracyjnej, Rity Charon, o którym chciałabym wspomnieć, jest Skandynawska Sieć Współpracy dla Narracji w Medycynie (ang. The Nordic Network for Narratives in Medicine, w skrócie NNNM). Jest to forum wymiany wiedzy i badań naukowych, interakcji nauczania i praktyki w interdyscyplinarnej przestrzeni literatury, filozofii i medycyny w krajach nordyckich, z siedzibą na Uniwersytecie Południowej Danii w Odense. Platforma ta ma przyczynić się do zaznaczenia obecności krajów nordyckich w domenie medycyny narracyjnej w Europie i na świecie. Dziedzina „literatury i medycyny” na arenie międzynarodowej rozwija się już od czterdziestu lat. Powstała jako reakcja na coś, co postrzegano jako dewaluacyjne tendencje w medycynie. Studiowanie literatury i filozofii zajmuje obecnie centralne miejsce w edukacji medycznej, w szczególności w USA i Anglii. W ostatnich dziesięciu-piętnastu latach widać wyraźny wzrost zainteresowania dziedziną medycyny narracyjnej i humanistyki medycznej w krajach skandynawskich. NNNM zamierza nie tylko wspierać tę tendencję, lecz także przyczynić się do zgromadzenia wszystkich osób zainteresowanych tą problematyką na jednym wspólnym forum. Inicjatywa ta ma zwiększyć możliwości 
zastosowania studiów literackich i filozoficznych w naukach społecznych i zdrowotnych. Wydaje się, że rok 2017 był właściwym momentem na nawiązanie dialogu z podobnymi, bardziej już ugruntowanymi ruchami na świecie, zarówno z uwagi na rosnące zainteresowanie krajami nordyckimi, jak i ze względu na wdrożenie kompleksowego wysiłku badawczego w prowadzone przez Skandynawów badania dotyczące narracji w medycynie. Rita Charon jest członkinią naukowej rady doradczej w NNNM, a Katarina Bernhardsson wchodzi w skład komitetu wykonawczego tej instytucji.

Pozostaje mi wyrazić nadzieję, że niniejszy artykuł przyczyni się do rozpropagowania idei medycyny narracyjnej także w Polsce. Jako podsumowanie przedstawionej relacji z doświadczeń skandynawskich chciałabym przytoczyć dwa cytaty, które uważam za szczególnie ważne:

Chorzy ludzie potrzebują lekarzy, którzy potrafią zrozumieć ich dolegliwości, leczyć ich problemy zdrowotne i towarzyszyć im w chorobach. Medycyna narracyjna jest zaangażowaniem w zrozumienie życia pacjentów, dbanie o opiekunów i w udzielanie głosu cierpieniu ${ }^{13}$.

Myślenie narracyjne ma kluczowe znaczenie dla zapewnienia terapeutom możliwości rozważenia niepełnosprawności w fenomenologicznych kategoriach życia upośledzonego. Myślenie narracyjne prowadzi terapeutów, zwłaszcza gdy leczą ciało fenomenologiczne; to znaczy, gdy są zaangażowani w doświadczanie choroby przez swoich pacjentów i w to, jak niepełnosprawność wpływa na ich życie. Tworzenie opowieści jako terapeutycznego emplotment (połączenia serii wydarzeń $w$ narrację $z$ fabuła) dotyczy sposobu, w jaki terapeuci pracują, żeby narracyjnie uporządkować terapię, a co za tym idzie, stworzyć poruszające zdarzenia terapeutyczne, które łączą terapię z życiem pacjenta ${ }^{14}$.

${ }^{13}$ Rita Charon, The patient-physician relationship. Narrative medicine: a model for empathy, reflection, profession, and trust, JAMA 2001, s. 1897-1902, cyt. za Kim Krisberg, Narrative Medicine: Every Patient Has a Story, AAMC News 2017.

${ }^{14}$ Cheryl Mattingly, The narrative nature of clinical reasoning, „American Journal of Occupational Therapy" 1991, s. 998-1005. Autorka jest profesorem antropologii na University of South Carolina, w Katedrze Antropologii i w Zakładzie Terapii Zajęciowej, jest też dyrektorem Inicjatywy na rzecz Zdrowia, Ludzkości i Kultury (na tymże uniwersytecie) oraz starszym pracownikiem naukowym w Institute for Advanced Studies of Aarhus University w Danii; zajmuje się także fenomenologią, filozofią etyki i teorią narracji. 


\section{Bibliografia}

Bernhardsson K., Litterära besvär: skildringar av sjukdom $i$ samtida svensk prosa, Ellerströms, Lund 2010.

Brattström V., Exclusion/inclusion in health care meetings (instalacja w ramach multidyscyplinarnego projektu badawczego, prezentowana na konferencji PARSE „On Exclusion", Göteborg, 15-17.11.2017).

Brattström V., Playing the 'Magic If': A theatre director's perspective on intervening, w: J. Woodilla, U.J. Sköldberg, A.B. Antal (red.), Artistic Interventions in Organizations: Research, Theory and Practice, Routledge, London 2015, s. 162-184.

Charon R., At the Membranes of Care: Stories in Narrative Medicine, „Academic medicine: journal of the Association of American Medical Colleges" 2012, nr 87(3), s. 342-347.

Charon R., Narrative Medicine: Honoring the Stories of Illness, Oxford University Press, New York 2006.

Charon R. i in., The Principles and Practice of Narrative Medicine, Oxford University Press, New York 2017.

Crafoord C., Människan är en berättelse: tankar om samtalskonst, Natur \& Kultur Akademisk, Stockholm 1994.

Groopman J., How Doctors Think, Boston-New York 2007.

Krisberg K., Narrative Medicine: Every Patient Has a Story, AAM CNews, March 28, 2017; https://news.aamc.org/medical-education/article/narrative-medicine-everypatient-has-story/ [dostęp: 14.10.2019].

Launer J., Narrative-Based Practice in Health and Social Care: Conversations Inviting Change, Routledge, London-New York 2018.

Mattingly Ch., Healing Dramas and Clinical Plots: The Narrative Structure of Experience, Cambridge University Press, Cambridge 1998.

Mattingly Ch., The narrative nature of clinical reasoning, „American Journal of Occupational Therapy" 1991, 45(11), s. 998-1005.

Mattingly Ch.,Fleming M.H., Clinical Reasoning: Forms of Inquiry in a Therapeutic Practice, F.A. Davis Company, Philadelphia, Pennsylvania 1994.

Mehl-Madrona L., Narrative Medicine: The Use of History and Story in the Healing Process, Bear \& Company, Rochester, Vermont 2007.

Sanders L., Every Patient Tells a Story: Medical Mysteries and the Art of Diagnosis, Harmony, New York 2009.

Sigurdson O., Sjukdomens kropp: Narrativitet, kroppslighet och relationalitet $i$ medicinsk praktik och omvårdnad, „Kritisk Forum for Praktisk Teologi” 2011, nr 123, s. 6-22.

Svenaeus F., Narrativ medicin: berättelsen om patienten och hennes sjukdom, „Läkartidningen” 2000, Vol. 97, nr 34, s. 3629-3632.

Tranströmer T., Wiersze i proza 1954-2004, przeł. L. Neuger, Wydawnictwo a5, Kraków 2012. 


\section{Źródła internetowe}

http://wardround.net/

http://narrativmedicin.se/konferens-stockholm-24-nov/narrative-medicine-can-deve-

lop-health-care/

http://narrativmedicin.se/

https://www.sol.lu.se/en/person/AndersPalm/

https://www.sol.lu.se/en/person/KatarinaBernhardsson/

\section{A B S T R A C T}

\section{Narrative Medicine in Sweden}

Effective care of patients requires profound and special knowledge about the patient, competence and commitment of the doctor and a solid bond of trust between them. Despite the many socio-cultural and professional factors that can divide doctors and patients and the impact of political and economic pressure on all health care, effective medical practice with careful listening and empathic attention must replace this hurried and impersonal one. Among many responses and countermeasures for the failure of the modern healthcare system is the professional Narrative Medicine program, developed at the New York Columbia University in 2000. The main aim of this paper is to present the genesis and development of narrative medicine in Sweden and to use its assumptions in clinical practice, both from the holistic perspective of the family doctor in the clinic and the clinician in the hospital ward. The author will also mention briefly the use of narrative methods and medical humanities in the education of medical faculty students in Sweden.

KEY WORDS: narrative medicine, Sweden, humanistic medicine

\section{A B S T R A K T}

\section{Medycyna narracyjna w Szwecji}

Skuteczna opieka nad pacjentami wymaga kilku elementów: dogłębnej wiedzy o pacjencie, odpowiednich kompetencji i zaangażowania lekarza oraz opartej na zaufaniu więzi między lekarzem a pacjentem. Pomimo wielu czynników: społeczno-kulturowych, zawodowych, politycznych i gospodarczych, które mogą dzielić lekarzy i pacjentów, skuteczna praktyka medyczna, bazująca na uważnym słuchaniu, na empatycznej uwadze, musi zastąpić tę pospieszną i bezosobową. Jedną z propozycji, które mogą uratować współczesny system opieki zdrowotnej, 
jest profesjonalny program medycyny narracyjnej, opracowany na Uniwersytecie Columbia w Nowym Jorku. Głównym celem tego artykułu było przedstawienie genezy i rozwoju medycyny narracyjnej w Szwecji oraz pokazanie sposobów wykorzystania założeń tej koncepcji w praktyce klinicznej - zarówno z holistycznej perspektywy lekarza rodzinnego, jak i z perspektywy lekarza pracującego na oddziale szpitalnym. Autorka wspomina również o zastosowaniu metod narracyjnych i humanistycznych w edukacji studentów medycyny w Szwecji.

SŁOWA KLUCZOWE: medycyna narracyjna, Szwecja, humanistyka medyczna 
Barbara Baranowska

Centrum Medyczne Kształcenia Podyplomowego

Antonina Doroszewska

Warszawski Uniwersytet Medyczny

Urszula Tataj-Puzyna

Warszawski Uniwersytet Medyczny

\section{„Opowiedz mi...”. Narracja w doświadczeniach ciąży, porodu i straty dziecka}

Położnictwo stanowi gałąź medycyny o dwóch różnych obliczach: pierwszym $z$ nich jest wspieranie naturalnych, fizjologicznych procesów związanych z macierzyństwem, drugim zaś - leczenie. Jest to dziedzina medycyny, której najczęściej jest bliżej do zdrowia niż do choroby. Ciąża i wydanie dziecka na świat stanowią naturalny proces, tak jak proces starzenia się, który prowadzi do naturalnej śmierci człowieka. Z tej perspektywy nie ma potrzeby interwencji czy leczenia. Jeśli w ciąży czy podczas porodu pojawiają się nieprawidłowości lub zaburzenia, wtedy konieczne są działania medyczne i opieka specjalistów. Poród wiąże się z wysiłkiem i bólem ból w fizjologicznym porodzie nie jest oznaką choroby, lecz stanowi część naturalnego procesu prowadzącego do urodzenia zdrowego dziecka.

Położnictwo jest jedną z najstarszych specjalności medycznych. Kobiety zawsze potrzebowały wsparcia $\mathrm{w}$ trudach i komplikacjach porodu. Od wieków zajmowały się tym akuszerki, ale było to także pole działań lekarzy. Zakres i sposoby niesienia pomocy kobietom w czasie porodu proponowane przez akuszerki i położników były odmienne. Ta kwestia wykracza jednak poza tematykę niniejszego artykułu.

Ze względu na podejście do opieki w okresie okołoporodowym można rozróżnić dwa typy położnictwa: położnictwo koncentrujące się na naturalnych, fizjologicznych procesach towarzyszących fenomenowi ciąży oraz położnictwo akcentujące i analizujące ryzyko wystąpienia patologii 
w ciąży, podczas porodu i w połogu, podkreślające konieczność intensywnego nadzoru i leczenia. Pierwszy typ stanowi domenę położnych, których nauczycielką jest natura ${ }^{1}$, drugi zaś stanowi profesję lekarzy położników. Ta dychotomia widoczna jest już na poziomie języka. W krajach anglosaskich położnictwo położnych definiuje się jako midwifery, a położnictwo lekarzy - jako obstetrics. Termin midwifery pochodzi od słowa midwife, które oznacza osobę towarzyszącą kobiecie i wspierającą ją. Termin obstetrics natomiast pochodzi od łacińskiego czasownika obstare, oznaczającego „stać przy kimś, być w gotowości”, i określa osobę stojącą obok, przygotowaną do udzielenia pomocy w odpowiednim momencie.

Położnictwo położników wiąże się zwykle z przeprowadzeniem określonej interwencji, dlatego czas i charakter kontaktu lekarza z kobietą rodzącą są ograniczone, sprowadzone głównie do wykonania zabiegu lub operacji. Położnictwo położnych (przynajmniej w modelu idealnym) to przede wszystkim relacja z rodzącą kobietą, towarzyszenie jej w tym doświadczeniu. W pracy położnej ciąża i poród są postrzegane w kontekście psychopedagogicznym ${ }^{2}$, a także w ujęciu biopsychospołecznym ${ }^{3}$. Narodziny dziecka są traktowane jako rytuał przejścia. Głównymi „narzędziami” w pracy położnej są: rozmowa, obserwowanie i wspieranie rodzącej, podążanie za naturalnym procesem rodzenia. W podejściu tym przyjmuje się założenie, że siła rodzenia tkwi w kobiecie, a mądrością położnej jest umiejętność pomagania rodzącej poprzez pobudzanie poczucia i tworzenie przestrzeni bezpieczeństwa. Położna ma raczej wydobywać z rodzącej nieuświadomioną wiedzę, tkwiący w niej potencjał. Nie bez powodu jeden z największych filozofów, Sokrates (notabene syn położnej), swoją metodę majeutyczną, wydobywającą z rozmówcy jego nieuświadomioną wiedzę, nazwał położniczą. Uważał, że nauczyciel to akuszer, który sprawia, że w uczniu „rodzi się” prawda. Metoda majeutyczna Sokratesa nie krępowała indywidualności ucznia, lecz rozbudzała jego ciekawość, stymulowała go do kreatywnego poszukiwania rozwiązania danego problemu ${ }^{4}$.

1 Stanisława Leszczyńska, Raport potożnej z Oświęcimia, „Przegląd Lekarski” 1965, s. 104-106.

${ }^{2}$ Emilia Lichtenberg-Kokoszka, Ciąża zagadnieniem biomedycznym i psychopedagogicznym, Kraków 2008, s. 9-20.

${ }^{3}$ Darby Saxbe, Birth of a new perspective? A call for biopsychosocial research on childbirth, „Current Directions in Psychological Science” 2017, s. 81-87.

${ }^{4}$ Sebastian Tabol, Uwagi o myśli pedagogicznej Sokratesa, „Kultura i Wychowanie" 2012, s. 49-62. 
Sokrates w swej metodzie nie występował w pozycji mistrza, ale - jak sam twierdził - był „akuszerem”, który pomaga przyjść na świat mądrości ukrytej w drugim człowieku. Nauczyciel i uczeń wspólnie dochodzili do prawdy. Metoda majeutyczna jest współcześnie opisywana jako filozoficzne źródło coachingu ${ }^{5}$. Dopatrując się tu pewnej analogii, można sformułować stwierdzenie, że położna ma być dla rodzącej „nauczycielem-akuszerem”, ma być jak coach, który wydobywa z kobiety nieuświadomioną wiedzę o tym, jak rodzić, który towarzyszy jej, bez narzucania swojej wizji porodu.

Irena Chołuj, położna z kilkudziesięcioletnim doświadczeniem, ujmuje rolę położnej następująco:

Położna ma po prostu być dla rodzącej. Czuwać przy niej i wspierać ją. Obserwować, jak zmienia się jej ciało. Słuchać, czego od nas potrzebuje. Odczytywać jej potrzeby $z$ gestów, mimiki, ze spojrzenia i pomagać tylko tyle, ile jej potrzeba ${ }^{6}$.

W pracy położnej ogromne znaczenie ma rozmowa i opowieść. Jak pisze Jo Gould, położnictwo położnych w swej naturze jest kulturą oralną ${ }^{7}$. Wiedza położnych pochodzi przede wszystkim z narracji rodzących kobiet, $z$ opowiadanych historii, a także $z$ wymiany doświadczeń między położnymi. Tak więc za podwaliny wiedzy położniczej akuszerek można uznać $\mathrm{W}$ większym stopniu storytelling niż pisma naukowe, obiektywne dane czy mierzalne fakty. Doświadczenia pokazują, że opowiadanie historii związanych z praktyką położniczą może poszerzyć wgląd położnych w jakość opieki, wykraczającej poza techniczną „obsługę” porodu. Może pogłębić ich intuicję i wrażliwość na potrzeby rodzącej oraz rozwinąć zdolność do odczytywania emocji kobiet; uświadamia im także istotę osobowej relacji z kobietą - relacji, która może wpływać na przebieg porodu. Opowiadanie historii związanych z praktyką kształtuje więc umiejętności niezbędne w skoncentrowanej na kobiecie praktyce położniczej ${ }^{8}$.

${ }^{5}$ Tatiana Krawczyńska-Zaucha, Filozoficzne źródła coachingu: metoda majeutyczna Sokratesa, „Coaching Review” 2017, s. 42-55.

${ }^{6}$ Irena Chołuj, Urodzić razem $i$ naturalnie. Informator $i$ poradnik porodowy dla rodziców $i$ położnych, Mszczonów 2008, s. 46-47.

${ }^{7}$ Jo Gould, Storytelling in midwifery: Is it time to value our oral tradition?, „British Journal of Midwifery" 2017, s. 41-45.

${ }^{8}$ O storytellingu, wpływie opowieści na wielowymiarowy rozwój kompetencji położnych pisali m.in.: Robbie Davis-Floyd i Elizabeth Davis, Intuition as authoritative knowledge in midwifery and home birth, "Medical Anthropology Quarterly” 1996, 
Celem niniejszego artykułu jest przedstawienie kilku obszarów $\mathrm{w}$ położnictwie, $\mathrm{w}$ których pojawiają się narracje, a także pokazanie przykładów narracji odnoszących się do doświadczeń związanych z porodem. Narracje w położnictwie to $z$ jednej strony opis doświadczeń kobiet, które opowiadają swoją indywidualną historię porodu, $z$ drugiej strony refleksje położnych towarzyszących kobietom podczas porodu. W tych opowieściach często pojawiają się takie kwestie, jak: relacja położnej i rodzącej kobiety, wsłuchiwanie się w potrzeby przyszłej matki, wgląd $\mathrm{w}$ istotę wykonywania zawodu. Najistotniejsze aspekty obecności narracji w położnictwie przedstawia następujący wykaz:

Narracje w położnictwie (w doświadczeniu ciąży i porodu)

1. Z perspektywy położnych

1.1. Dzielenie się opowieściami (ang. sharing practice)

1.2. Wspomnienia i nauczanie empatii

1.3. Metafory $w$ dyskursie porodowym

2. Z perspektywy kobiet rodzących

2.1. Przekazy rodzinne

2.2. Kręgi opowieści porodowych

2.3. Opisy własnych doświadczeń

\section{Narracje położnych}

Przekazywanie wiedzy w położnictwie w dużej mierze bazuje na „dzieleniu się praktyką". Przez stulecia źródłem wiedzy akuszerek były wnikliwe obserwacje przekazywane wśród kobiet $\mathrm{w}$ formie opowieści. Dopiero w XX wieku zaczęto przeprowadzać badania naukowe, których wyniki - opisywane $\mathrm{w}$ fachowych publikacjach - stanowią podstawę współczesnej nauki medycznej z zakresu położnictwa. Z czasem okazało się, że wiele obserwacji czynionych latami przez akuszerki znalazło potwierdzenie w wynikach tych badań. Przykładami takich obserwacji są m.in. korzystny wplyw na przebieg porodu takich praktyk, jak immersja

s. 237-269; Jane Fry, A descriptive phenomenological study of independent midwives' utilisation of intuition as an authoritative form of knowledge in practice, Bournemouth 2016 (praca doktorska); Lauren Hunter, A hermeneutic phenomenological analysis of midwives' ways of knowing during childbirth, „Midwifery” 2008, s. 405-415; Lauren P. Hunter i Linda A. Hunter, Storytelling as an educational strategy for midwifery students, „Journal of Midwifery \& Women's Health” 2006, s. 273-278. 
wodna (czyli kąpiel w wannie, wykorzystywana jako metoda łagodzenia bolesnych skurczów porodowych), hipnoza czy niezszywanie małych pęknięć krocza ${ }^{9}$.

Drugim obszarem, w którym pojawia się narracja położnych, jest pisanie wspomnień, świadectw czy pamiętników. Jednymi z najbardziej znanych są wspomnienia położnej Stanisławy Leszczyńskiej $z$ niemieckiego obozu koncentracyjnego Auschwitz-Birkenau. Oto ich fragment:

Wśród licznych transportów kobiet, które przybywały do tego obozu, nie brak było kobiet ciężarnych. Funkcje położnej pełniłam tam kolejno na trzech blokach. [...] Na bloku panowały ogólnie: infekcja, smród i wszelkiego rodzaju robactwo. Roiło się od szczurów, które odgryzały nosy, uszy, palce czy pięty opadłym z sił i nie mogącym się poruszać ciężko chorym kobietom. [...] Porody odbywały się na zbudowanym $z$ cegieł piecu w kształcie kanału [...] W opisanych warunkach pracowałam przez dwa lata, dzień i noc bez zastępstwa. [...] Dzieci nie otrzymywały żadnych przydziałów żywnościowych, ani nawet kropli mleka. Marły powolną śmiercią głodową. Towarzyszyła im wielka miłość i bezsilność matek z bloku. [...] Wszystkie dzieci urodziły się żywe. Ich celem było żyć! Obóz przeżyło zaledwie trzydzieści. Nie miałam dotychczas okazji przekazać Służbie Zdrowia swego raportu położnej z Oświęcimia. Przekazuję go teraz w imieniu tych, którzy o swej krzywdzie nie mogli powiedzieć światu, $\mathrm{w}$ imieniu matki i dziecka ${ }^{10}$.

Stanisława Leszczyńska - na przekór terrorowi i otaczającemu ją zewsząd złu - tworzyła atmosferę nadziei, poprzez czułą opiekę przywracała godność matkom, które w obozie rodziły swoje dzieci.

Publikacje doświadczonych położnych, mające charakter wspomnień czy świadectw, stanowią kluczowy element $\mathrm{w}$ nauczaniu etyki zawodu i w kształtowaniu postawy moralnej studentów. Opowieści położnych, pełne metafor, pochodzące $z$ różnych okresów historycznych i różnych rejonów świata, kształtują wrażliwość przyszłych adeptów położnictwa oraz wpływają na szerokie, integralne postrzeganie tego zawodu, nieograniczające się tylko do technicznej „obsługi” porodu. Poprzez czytanie o trudach pracy położnej, a jednocześnie o wyjątkowości i majestatyczności

${ }^{9}$ Jo Gould, Storytelling in midwifery: Is it time to value our oral tradition?, „British Journal of Midwifery" 2017, s. 41-45.

10 Stanisława Leszczyńska, Raport położnej z Oświęcimia, „Przegląd Lekarski” 1965, s. 104-106. 
doświadczenia zawodowego, studenci położnictwa kształtują w sobie postawę szacunku wobec przyszłego zawodu ${ }^{11}$.

Po ćwierć wieku pracy w zawodzie położnej Irena Chołuj opisała swoje obserwacje i przeżycia związane $z$ towarzyszeniem rodzącym kobietom podczas porodu $\mathrm{w}$ domu. To doświadczenie pozwoliło jej inaczej spojrzeć na wykonywaną pracę, uświadomiło istnienie innego położnictwa, w którym położna „przyjmuje dziecko”, a nie je odbiera. Refleksje te, przywołane niżej, wpłynęły na jej postawę zawodową także w ramach pracy w szpitalu:

Wszystko mnie dziwiło i zachwycało - Joli spokój, oddech, którego nie musiałam nadzorować. W ogóle się nie wtrącałam, tylko współuczestniczyłam. Razem z nią oddychałam, razem $z$ nią chodziłam. Przejmowałam jej tempo aktywności. Nie wiem, skąd wiedziałam, że tak trzeba. W ten sposób uczylam się być $z$ rodzącą.

To było piękne, wspaniałe przeżycie, a nie „odbieranie porodu”. [...]

Tak się urodził Konrad. Cichutko, gały otwarte... Widziałam, że on się patrzy na mnie ze zdziwieniem. Naprawdę, nie było w nim złości, nie musiał bronić się przed nową rzeczywistością [...].

Nigdy czegoś takiego nie przeżyłam, chociaż to był dwudziesty piąty rok mojej pracy zawodowej [...].

To było zupełnie inne położnictwo. Coś we mnie się przemieniło. Poczułam się zjednoczona z rodzicami i wiedziałam, że będę w szpitalu robić wszystko, żeby zminimalizować sytuacje, które ranią rodzącą ${ }^{12}$.

Ina May Gaskin wskazywała na duchowość i religijność położnej, które rozumiała jako troskę o innych i współczucie. Według niej mają one być sposobem życia położnej. Położna żyjąca zgodnie z zasadami współczucia zestraja się z biologicznym procesem narodzin, który powtarza się od milionów lat. Zdaniem Gaskin słowa, jakimi położna zwraca się do rodzącej, oraz sposób, w jaki ją dotyka, mają ogromy wpływ na jakość późniejszego macierzyństwa, mogą dokonać wielkich zmian w świadomości podopiecznej. Jednak aby dotyk, gest i słowo położnej miały w sobie

${ }^{11} \mathrm{Na}$ wyjątkowe doświadczenie zawodowe położnych zwracają uwagę takie autorki, jak: Sylwia Szwed, Mundra, Warszawa 2014; Jennifer Worth, Zawołajcie położną, Warszawa 2014; Ina May Gaskin, Spiritual Midwifery, Summertown 2002; Ewa Janiuk i Emilia Lichtenberg-Kokoszka (red.), Domowe narodziny. Fanaberia szaleńców czy powrót do normalności?, Kraków 2010.

12 Sylwia Szwed, Mundra, op. cit., s. 147-148. 
moc miłości, położna musi - według Gaskin - być w stanie łaski; powinna złożyć takie same śluby duchowe jak zakonnice czy mnisi. Sama autorka pisze o tym tak: „Położna musi stale inwestować w swoją zdolność wspólczucia, otwartości i jasności wizji, ponieważ miłość, współczucie i perspektywa duchowa są najważniejszymi narzędziami w jej rzemiośle"13. Autorka uważa, że każde narodziny są święte. W swojej książce przybliża znaczenie duchowości w zawodzie położnej:

Myślę, że położna musi być religijna, ponieważ energia, z którą ma do czynienia, jest święta, musi wiedzieć, że energia innych ludzi jest świętością. Duchowa położna traktuje każde narodziny jako narodziny Dzieciątka Jezus. Zadaniem położnej jest zrobić wszystko, co w jej mocy, aby utrzymać Świętość sakramentu narodzin ${ }^{14}$.

Położne często zwracają uwagę na humanistyczny aspekt ich pracy. Podkreślała to m.in. Stefania Hoch:

Ta wyjątkowa, najpiękniejsza posługa, jaką może dać człowiekowi człowiek - pomoc kobiecie oczekującej narodzin dziecka, rodzącemu się nowemu życiu na Ziemi - powinna być szanowana i uznawana przez każdą społeczność. Osoba udzielająca pomocy, prowadząca trudną ścieżką nienarodzoną istotę $\mathrm{w}$ świat samodzielnego życia, jakim jest oddychanie, swobodny ruch w przestrzeni życia pozamacicznego, jest dobroczyńcą dla rodzącej kobiety, jej rodziny i potomka ${ }^{15}$.

Doświadczenia całego pokolenia kobiet, które rodziły swoje dzieci w drugiej połowie XX wieku w polskich szpitalach, pokazują, jak zmedykalizowane zostało postrzeganie porodu przez fachowy personel. Istotę zawodu oraz rolę położnej uchwyciła i w takich słowach wyraziła Irena Chołuj:

[...] położna może i powinna na nowo odmedykalizować poród fizjologiczny, „odczarować” strach kobiet przed naturalnym rodzeniem niezależnie od ich wyboru miejsca do narodzin dziecka. [...] Coraz więcej kobiet

13 Ina May Gaskin, Duchowe położnictwo. Intymność narodzin, przeł. J. Janisiewicz, Warszawa 2009, s. 283.

${ }^{14}$ Ibidem, s. 282.

15 Stefania Hoch, Wspomnienia i refleksje pielęgniarki, położnej, nauczycielki zawodu, w: Od Szkoty babienia po Uniwersytet. Dzieje ksztatcenia położnych $w$ Warszawie 1802-2012, Warszawa 2012, s. 402. 
wybierających szpital chce rodzić tam naturalnie, nie chcą być „leczone z powodu porodu" ${ }^{\prime 6}$.

O roli położnych w dążeniu do ograniczenia skali medykalizacji porodu pisała również Ewa Janiuk:

Aby chronić rodzące kobiety i ich dzieci przed powikłaniami okołoporodowymi, medykalizujemy poród $\mathrm{w}$ tak wysokim stopniu, że sami stajemy się wręcz zagrożeniem w czasie jego trwania. [...] Odkrywanie fizjologii daje wielką satysfakcję, ale jeszcze większą przygodą i radością jest czerpanie z mądrości naturalnie uporządkowanego świata ${ }^{17}$.

\section{Narracje kobiet}

O ciąży i porodzie powstaje w ostatnich latach wiele opowieści mających charakter tworzonych przez kobiety narracji. Stanowią one przestrzeń dla zrelacjonowania własnej historii, opowiedzenia o indywidualnym doświadczeniu. Opowieść odgrywa również ważną rolę w przygotowaniu do ciąży. Kobiety oczekujące dziecka chętnie słuchają relacji innych kobiet, a opowiadanie o przyszłym macierzyństwie stanowi element budowania więzi z nienarodzonym jeszcze dzieckiem.

W narracjach kobiet dominują opisy doświadczenia porodu, doznań i towarzyszących im emocji. Częstym sposobem przedstawiania rozwijającej się akcji porodowej jest opisywanie jej za pomocą metafory fali. Poród to proces, to falowanie nasilających się uczuć, kolejno pojawiających się skurczy i chwil odpoczynku. Każdy skurcz jest jak fala, która przychodzi i odchodzi, dając chwilowe wytchnienie przyszłej matce i przybliżając ją do spotkania $\mathrm{z}$ dzieckiem. Z opowiadań matek można wyczytać także, że $\mathrm{w}$ proces rodzenia zaangażowana jest cała rodzina: matka, ojciec i dziecko. Oto fragment, który ilustruje oba wspomniane motywy:

Niedziela [...]. Pierwszy dzień reszty życia. Kilkadziesiąt minut po północy obudził mnie silny skurcz. Przekręciłam się na bok, licząc po cichu, że to już ten moment, ale nie chciałam zapeszać. Za moment kolejny skurcz i kolejny.

${ }^{16}$ Irena Chołuj, Siła rodzenia tkwi w kobiecie, a w położnej siła umiejętności pomagania rodzącej, w: E. Janiuk, E. Lichtenberg-Kokoszka (red.), Domowe narodziny. Fanaberia szaleńców czy powrót do normalności?, Kraków 2010, s. 8.

${ }^{17}$ Ewa Janiuk, Emilia Lichtenberg-Kokoszka (red.), Domowe narodziny ..., op. cit., s. 245 . 
Oho. Maleńki daje znać. Już czas. Mąż nie spał jeszcze. Patrzył na mnie czujnym, czułym okiem, gdy zaczęłam swoje porodowe rytuały. Oddech. Zamknięte oczy. Poddanie się fali, która zaczęła mnie dość regularnie ogarniać. Muzyka - krótka mieszanka moich ulubionych kawałków, kilka nowych poznanych dzięki Mojej Douli. Lubię tak o Niej mówić. Moja. Ruch. I ta Radość - taka, która sprawia, że aż chce się skakać i krzyczeć! No i masa śmiechu. Poczucie humoru to cecha, którą najbardziej cenię u Męża. Za niedługo miałam się przekonać na własnym ciele o słowach Iny May Gaskin, że śmiech otwiera. Fala ogarniała mnie raz silniej, raz słabiej, ale regularnie, w krótkich odstępach. Nie było wątpliwości - dziś przywitamy Maleńkiego ${ }^{18}$.

Narracje kobiet pozwalają położnym wczuć się w różne sytuacje podopiecznych: usłyszeć przekaz kobiety żegnającej dziecko, które zmarło w jej łonie, czy wysłuchać radości, jaką daje tulenie noworodka. Trudne macierzyństwo, w którym kobieta przeżywa śmierć dziecka, może być doświadczeniem wzmacniającym, zwłaszcza jeśli w sytuacji utraty nie została pozbawiona godności bycia matką. W literaturze można odnaleźć wiele takich narracji. Oto jedna $z$ nich:

Moja matka też straciła dziecko, które opuściło jej łono kilka miesięcy za wcześnie. Kobiety odwracały wzrok od maciupeńkiej, straconej dziewczynki, ale ja widziałam tylko jej doskonałe piękno. Jej powieki były pożyłkowane niczym skrzydło motyla, paluszki u stóp skręcały się niczym płatki kwiatu. Tuliłam w objęciach siostrzyczkę, której nigdy nie nadano imienia, która nie otwarła nigdy oczu i która zmarła w moich ramionach. Nie bałam się trzymać w ręku tej maleńkiej śmierci. Twarz dziecka była pogodna, rączki doskonale czyste. Zdawało się, że lada moment się obudzi. Moje łzy padały na jej alabastrowy policzek i odniosłam wrażenie, że ona żałuje utraty własnego życia. Moja matka podeszła odebrać ode mnie siostrę, ale ujrzawszy mój smutek, pozwoliła mi zanieść ją na miejsce pochówku. Została owinięta w skrawek z najprzedniejszej tkaniny i złożona pośród korzeni najsilniejszego i najstarszego drzewa, jakie było widoczne z namiotu mej matki. Nie złożono żadnej ofiary, ale kiedy tobołek został przysypany ziemią, były westchnienia, jakie dobyły się z ust moich matek, były równie wymowne jak każda modlitwa ${ }^{19}$.

Strata dziecka w okresie okołoporodowym stanowi dramat dla rodziców i wciąż w wielu przypadkach wiąże się z brakiem empatii ze strony otoczenia.

${ }^{18}$ http://www.vivatporod.pl/pl,szczesliwe_historie,kasia_i_krzysztof,1 [dostęp 29.11.2018].

19 Anita Diamant, Czerwony namiot, Poznań 2017, s. 189-190. 
Kobiety dzielą się opisami przeżyć związanych z poronieniem, określanym jako „przerwane” lub „przegrane” narodziny ${ }^{20}$. Narracje o stracie dziecka przybierają nieraz kształt listów matek do ich nienarodzonych dzieci. Stanowią one element terapii wspierającej rodziców po stracie dziecka:

Jaka będziesz skrzydlata istoto ze świata czarów, gwiezdnych atomów nieskończonej miłości? Oto ja zbolała i zapłakana za Tobą, mimo że TY jeszcze jakbyś była, a jednak już Cię nie ma. [...] Twój ojciec mówi, że jesteś nadal w moim brzuchu i zaczekasz cierpliwie na następne ciałko, które zechce Cię przyjąć, i chyba ma rację. Ale teraz mój brzuch płacze za tą cienką nicią, która połączyła się z moim sercem, i na drugim końcu której jest jedynie ciemność i krew ${ }^{21}$.

W położnictwie kobiety dzielą się opowieściami z własnych porodów, tworząc w ten sposób „kręgi opowieści porodowych”22. Każda historia porodowa może wzmocnić kobiety i dać im ogromną wewnętrzną siłę. W takich opowieściach kobiety szukają źródeł mocy, budują pozytywne nastawienie do porodu, który może być jednocześnie trudnym i pięknym przeżyciem, jest w stanie głęboko poruszyć i transformować rodzącą - po nim życie matki może nabrać całkiem nowego wymiaru. Kobiety dają wyraz swoim przeżyciom także poprzez pisanie listów w ramach akcji „Rodzić po Ludzku” czy „Lepszy Poród”. Oto dwa przykłady takich wypowiedzi:

Dostałam skurczy 5 tyg. przed czasem, potraktowano mnie jakbym specjalnie wywołała sobie poród, po bolesnym badaniu ordynator zapytał mnie z pretensją, czy wiem, jak się wychowuje wcześniaki. Byłam sama, przerażona i zagubiona. Po porodzie leżałam na sali z trzema szczęśliwymi mamami i ich dziećmi. Nigdy nie doświadczyłam gorszej tortury. Do dziś mam wyrzuty sumienia, że nie urodziłam $w$ terminie, a minęło 5 lat $^{23}$.

Będąc w zaawansowanej ciąży, dowiedziałam się, że moja córeczka jest chora i wkrótce umrze. W szpitalu położono mnie na sali z noworodkami, kiedy

${ }^{20}$ Magdalena Wojaczek, Aniołkowe mamy. Historie kobiet, które poronity. Porady ekspertów, Warszawa 2009; Izabela Barton-Smoczyńska, O dziecku, które odwrócito się na pięcie, Częstochowa 2015; Renata Kleszcz-Szczyrba, Witraże w ciemności, czyli o przedwczesnej śmierci dziecka, Katowice 2014.

${ }^{21}$ Giorgia Cozza, Przerwane oczekiwanie. Poradnik dla kobiet po poronieniu, przeł. A. Paleta, Warszawa 2013, s. 170.

${ }^{22}$ Krystyna Dzwonkowska-Godula, Opowieści porodowe - historie o szczególnym kobiecym doświadczeniu i podmiotowości kobiet; http://wladzasadzenia.pl/2016/9/opowiesci-porodowe-historie-o-szczegolnym-kobiecym-doswiadczeniu-i-podmiotowoscikobiet.pdf [dostęp 15.12.2018].

23 \#lepszy poród, wpis anonimowy. 
powiedziałam pielęgniarkom, że nie mogę tego znieść psychicznie, usłyszałam, że mam nie marudzić i cieszyć się, że mam miejsce - do dziś mam koszmary senne związane ze szpitalem² ${ }^{24}$.

W ostatnich latach coraz popularniejsze stają się fora internetowe, na których kobiety opisują swoje doświadczenia z porodu. Warto przywołać istniejące od kilku lat na Facebooku forum „Naturalnie po cesarce - grupa wsparcia”, skupiające kobiety mające za sobą doświadczenia porodów drogami natury po wcześniejszym cesarskim cięciu. Obecnie do grupy tej należy ponad jedenaście tysięcy osób. Znaleźć tu można ogromną liczbę świadectw, opowieści położniczych, opisów doświadczeń po jednym, dwóch czy nawet trzech cesarskich cięciach. W tej grupie kobiety wymieniają się doświadczeniami, konsultują się z położnymi, opisują swoją walkę o prawo do podjęcia próby porodu naturalnego po wcześniejszym cesarskim cięciu ${ }^{25}$. W przywołanych niżej fragmentach mowa jest o radości i dumie, jakie daje matkom przeżycie porodu naturalnego:

Dziś rano przyszedł na świat nasz Syn Ignaś, urodzony siłami natury po 2cc zrobionych na zimno!!! Uczucia nie do opisania, mogłam doświadczyć ciepła tego maleńkiego ciałka i w ogóle całej tej magii. Pępowinę przecięłam dopiero, jak przestała tętnić, mieliśmy nieprzerwany kontakt skóra do skóry przez prawie 3 godziny!! Później wzięłam prysznic, zjadłam śniadanie, mogłam bez problemu zająć się Maluszkiem - zupełnie inna rzeczywistość niż po CC! Ten poród to duży wysiłek dla całej naszej Rodziny, ale było warto, bez wątpienia!!! ${ }^{26}$

Moja córka Lilia urodziła się [...] po dwudziestu trzech i pół godzinie porodu (z czego $18 \mathrm{w}$ domu), 6 dni po terminie, 13 miesięcy po cesarskim cięciu. Było to tak cudowne i budujące doświadczenie, że nie sposób tego opisać. To, co dał mi poród naturalny, zmieniło moje postrzeganie siebie, przesunęło granice tego, co jestem w stanie wytrzymać, i dało wiarę w to, ile mogę zrobić. Czułam, że mój poród dzieje się naprawdę - nie jak podczas cesarki. Doświadczenie bólu do tych $7 \mathrm{czy}$ może nawet $8 \mathrm{~cm}$ nie było złym doświadczeniem. Gdybym miała określić poród jednym słowem, byłoby to słowo POWER tyle, że czcionką 72. Cały jego obraz jest dla mnie piękny i długo, długo będę z niego czerpać.

24 \#lepszy poród, wpis anonimowy.

25 „Naturalnie po cesarce - grupa wsparcia”; https://www.facebook.com/groups/597718530295741/ [dostęp 6.01.2019].

${ }^{26}$ Ibidem. 
Mimo dużej intensywności mojego porodu oraz bardzo szybko postępującej akcji, co sprawiło, że te kilka godzin wspominam jako jeden ogromny ból - nie zmieniłabym swojej decyzji - narodziny dziecka, choć nie należą do przyjemnych fizycznie odczuć, psychicznie dają wielką moc i inny wymiar więzi z dzieckiem ${ }^{27}$.

Opowieść o porodzie jest również motywem w poezji. Wiersz Zwykty poród Anny Świrszczyńskiej ukazuje intensywność procesu porodowego:

Dwadzieścia godzin

wyje jak zwierzę.

Lekarz chce jej pomóc.

Nacina nożyczkami żywe ciało

bez znieczulenia.

Nie zauważa tego.

Zbyt potężna

jest tortura rozstępujących się kości.

Jaki szatan

wymyślił świat ${ }^{28}$.

Potrzeba opowiadania o doświadczeniu początków macierzyństwa nie kończy się z chwilą urodzenia dziecka. Wiele kobiet opisuje również czas karmienia piersią, który dla części z nich stanowi okres trudny, wymagający dużego poświęcenia. Przedstawiony fragment ilustruje zderzenie wyobrażeń o macierzyństwie z rzeczywistością:

Nie spodziewałam się, że dziecko tak mocno zasiedla matkę. Słyszałam, że małe dziecko je i śpi - z naciskiem na śpi. A ja spędziłam trzy miesiące na fotelu. [...] Potem pogodziłam się z tym, że tak to wygląda. To pogodzenie bardzo ułatwia życie ${ }^{29}$.

\section{Narracje w dydaktyce}

Opowieści kobiet mogą być wykorzystywane w dydaktyce. Jak wspomniałyśmy wcześniej, głównym narzędziem w pracy położnej jest relacja

27 Ibidem.

28 Anna Świrszczyńska, Poezja, Warszawa 1997, s. 179.

${ }_{29}$ Marianna Szymarek, Opowieści o karmieniu piersią. Przełamując bariery, Warszawa 2014, s. 48. 
z rodzącą kobietą, mająca charakter towarzyszenia jej w rytuale przejścia. Współczesny trend zmierzający do zmedykalizowania ciąży i porodu pociąga za sobą odhumanizowanie i uprzedmiotowienie kobiety. Dla przyszłych adeptek sztuki położniczej narracje - zarówno rodzących, jak i położnych - stanowią ważne źródło wiedzy. W opowieściach tych widać różnicę między opieką okołoporodową opartą na zasadach podmiotowości i autonomii kobiety a taką, w której rodząca zostaje uprzedmiotowiona i podporządkowana procedurom medycznym.

Narracje profesjonalistów związane z praktyką położnych mogą uzmysłowić studentom, że istota opieki nad rodzącą wykracza poza techniczną sferę porodu. Opowieści profesjonalistów, bazujące na ich doświadczeniu zawodowym, mogą pomóc przyszłym położnym w przygotowaniu się do zawodu, którego istotą jest - powtórzmy - podążanie za naturalnym procesem rodzenia. Zapoznawanie się $z$ opowieściami położnych może pomagać $\mathrm{w}$ zrozumieniu wartości, na których opiera się wykonywanie tego zawodu, w pogłębieniu refleksji nad trudnymi sytuacjami zdarzającymi się w praktyce. Jest to również sposób na budowanie u studentów postawy zawodowej skoncentrowanej na kobiecie. Poznanie narracji położnych, m.in. Stanisławy Leszczyńskiej, i dyskusja nad nimi stanowią element kształcenia studentów położnictwa na Warszawskim Uniwersytecie Medycznym czy Uniwersytecie Warmińsko-Mazurskim w Olsztynie. Wczytywanie się w opowieści rodzących sprzyja także kształtowaniu empatycznej postawy położnych już pracujących w zawodzie, które doskonalą swoje kompetencje w ramach kształcenia podyplomowego.

Close reading ${ }^{30}$ jako metoda analizy i interpretacji tekstów, stosowana podczas szkoleń z medycyny narracyjnej na Uniwersytecie Columbia, jest sposobem na wywołanie i podtrzymanie u personelu medycznego czy studentów kierunków medycznych postawy empatycznej i humanistycznego spojrzenia na indywidualne sytuacje pacjentów. Sytuacje te obejmują nie tylko problemy ściśle medyczne, lecz także szereg uwarunkowań psychospołecznych i kulturowych. Jako materiał dydaktyczny do pracy ze studentami mogą posłużyć gotowe opowieści - opublikowane w książkach, dostępne w internecie. Można również zachęcić studentów (bądź pracujące położne, jeśli wykorzystujemy metody medycyny narracyjnej

30 Więcej o metodach rozwijania kompetencji narracyjnej w ramach warsztatów z medycyny narracyjnej zob. w artykule „Metoda uważnego czytania (close reading) w medycynie narracyjnej” w tej książce. 
w kształceniu podyplomowym) do samodzielnego tworzenia takich narracji albo do wzajemnego dzielenia się opowieściami z pacjentami. Dostępne narracje (szczególnie pojawiające się w nich problemy) mogą stanowić punkt wyjścia do dyskusji w grupie lub do samodzielnej pracy w postaci reflective writing.

Medycyna narracyjna stanowi odpowiedź na przedmiotowe traktowanie chorych, w którym pomija się psychospołeczny i kulturowy aspekt ich funkcjonowania $^{31}$. W położnictwie opowiadanie historii porodowych jest przejawem kształtowania się podmiotowej samoświadomości współczesnych kobiet. Wypowiedzi matek, które opisują trud i zmagania podczas porodu (doświadczenia egzystencjalnego zmieniającego na zawsze ich życie), podkreślają doniosłość, intensywność i niezwykłość przeżyć okołoporodowych. Narracje porodowe wzmacniają w kobietach świadomość własnego ciała i ogromnej wewnętrznej siły. W tych opowieściach poród jest przedstawiany jako doświadczenie bardzo dynamiczne. Kobiety ujmują go jako proces, ruch, falowanie, sekwencję następujących po sobie doznań, powtarzających się i nasilających wraz z przebiegiem porodu. Szczególne miejsce w tych opisach zajmują doznania bólowe, przedstawiane jako fala, która przychodzi i odchodzi. Położne, świadome tej intuicyjnej konceptualizacji doświadczenia bólowego, mogą wykorzystać taki sposób mówienia $\mathrm{w}$ relacji z rodzącą kobietą, dając jej w ten sposób poczucie zrozumienia i bezpieczeństwa.

Opowieści o porodzie od wieków towarzyszyły kobietom i akuszerkom, a współcześnie położnym. Stanowiły źródło zrozumienia potrzeb rodzących, były przyczynkiem do obserwacji zależności, które następnie sprawdzano empirycznie. Rozwój medycyny, zwłaszcza technologii, w ogromnym stopniu przyczynił się do przeobrażeń w zakresie sprawowania opieki położniczej. W niewielkim stopniu zmieniła się jednak istota opieki położnej nad rodzącą. Poznanie narracji kobiet i doświadczonych położnych może wzmacniać kompetencje adeptek tego zawodu. Dlatego warto uwzględniać elementy medycyny narracyjnej $\mathrm{w}$ procesie kształcenia studentów położnictwa, a także włączać je w program kształcenia podyplomowego, skierowanego do położnych już praktykujących. Najważniejsze narzędzia medycyny narracyjnej, takie jak close reading, parallel charts, creative writing i reflective writing, szczegółowo opisane przez Ritę

31 Patrycja Zurzycka, Teresa Radzik, Medycyna narracyjna - zarys problematyki, „Problemy Pielęgniarstwa” 2015, s. 428-432. 
Charon $^{32}$, można wykorzystać zarówno podczas kształcenia teoretycznego, jak i praktycznego. Medycyna narracyjna stanowi metodologiczne ramy, ale też uzasadnienie dla intuicyjnie dotąd powstających narracji o porodzie.

Dążąc do połączenia położnictwa z medycyną narracyjną, możemy powiedzieć, że położnictwo jest narracją życia: zachwyca swą intensywnością, doniosłością i niezwykłością. Położnictwo jest usłane opowieściami i wyznaczone każdą wspólnie przebytą z kobietą matką drogą.

\section{Bibliografia}

Barton-Smoczyńska I., O dziecku, które odwróciło się na pięcie, Wydawnictwo Edycja Świętego Pawła, Częstochowa 2015.

Charon R., Narrative Medicine: Honoring the Stories of Illness, Oxford University Press, New York 2006.

Charon R. i in., The Principles and Practice of Narrative Medicine, Oxford University Press, New York 2017.

Chołuj I., Siła rodzenia tkwi w kobiecie, a w położnej siła umiejętności pomagania rodzącej, w: E. Janiuk, E. Lichtenberg-Kokoszka (red.), Domowe narodziny. Fanaberia szaleńców czy powrót do normalności?, Oficyna Wydawnicza Impuls, Kraków 2010.

Chołuj I., Urodzić razem i naturalnie. Informator i poradnik porodowy dla rodziców i położnych, Źródła Życia, Mszczonów 2008.

Cozza G., Przerwane oczekiwanie. Poradnik dla kobiet po poronieniu, przeł. A. Paleta, B. Sosnowska, Wydawnictwo Mamania, Warszawa 2013.

Davis-Floyd R., Davis E., Intuition as authoritative knowledge in midwifery and home birth, „Medical Anthropology Quarterly” 1996, 10(2), s. 237-269.

Dąbrowska J., Matka młodej matki, Wydawnictwo Mamania, Warszawa 2016.

Diamant A., Czerwony namiot, przeł. K. Kaliska, Wydawnictwo Rebis, Poznań 2017. Dzwonkowska-Godula K., Opowieści porodowe - historie o szczególnym kobiecym doświadczeniu i podmiotowości kobiet; http://wladzasadzenia.pl/2016/9/opowiesci-porodowe-historie-o-szczegolnym-kobiecym-doswiadczeniu-i-podmiotowosci-kobiet. pdf [dostęp 15.12.2018].

Fry J., A descriptive phenomenological study of independent midwives' utilisation of intuition as an authoritative form of knowledge in practice, Bournemouth University, Bournemouth 2016.

Gaskin I.M., Duchowe położnictwo. Intymność narodzin, przeł. J. Janisiewicz, Wydawnictwo Virgo, Warszawa 2009.

32 Rita Charon, Narrative Medicine: Honoring the Stories of Illness, New York 2006; eadem i in., The Principles and Practice of Narrative Medicine, New York 2017. 
Gaskin I.M., Spiritual Midwifery, Book Publishing Company, Summertown 2002.

Gould J., Storytelling in midwifery: Is it time to value our oral tradition?, „British Journal of Midwifery" 2017, 25(1), s. 41-45.

Hoch S., Wspomnienia i refleksje pielęgniarki, położnej, nauczycielki zawodu, w: J. Bień (red.), Od Szkoty babienia po Uniwersytet. Dzieje kształcenia położnych $w$ Warszawie 1802-2012, Wydawnictwo Medyczne Borgis, Warszawa 2012.

Hunter L.P., A hermeneutic phenomenological analysis of midwives' ways of knowing during childbirth, „Midwifery” 2008, 24(4), s. 405-415.

Hunter L.P., Hunter L.A., Storytelling as an educational strategy for midwifery students, „Journal of Midwifery \& Women's Health” 2006, 51(4), s. 273-278.

Janiuk E., Lichtenberg-Kokoszka E. (red.), Domowe narodziny. Fanaberia szaleńców czy powrót do normalności?, Oficyna Wydawnicza Impuls, Kraków 2010.

Kleszcz-Szczyrba R., Witraże w ciemności, czyli o przedwczesnej śmierci dziecka, Wydawnictwo Księgarnia św. Jacka, Katowice 2014.

Krawczyńska-Zaucha T., Filozoficzne źródła coachingu: metoda majeutyczna Sokratesa, „Coaching Review” 2017, 1(9), s. 42-55.

Lichtenberg-Kokoszka E., Ciaża zagadnieniem biomedycznym i psychopedagogicznym, Oficyna Wydawnicza Impuls, Kraków 2008.

Leszczyńska S., Raport położnej z Oświęcimia, „Przegląd Lekarski” 1965, 21(2), s. 104-106.

Morch D.T., Winter's child, University of Nebraska Press, Lincoln 1987.

Nasiłowska A., Domino-traktat o narodzinach, Wydawnictwo Open, Warszawa 1995.

Nasiłowska A., Księga początku, Wydawnictwo W.A.B., Warszawa 2002.

Saxbe D., Birth of a new perspective? A call for biopsychosocial research on childbirth, „Current Directions in Psychological Science” 2017, 26(1), s. 81-87.

Szwed S., Mundra, Wydawnictwo Czarne, Warszawa 2014.

Szymarek M. (red.), Opowieści o karmieniu piersią. Przełamujac bariery, Wydawnictwo Mamania, Warszawa 2014.

Świrszczyńska A., Poezja, PIW, Warszawa 1997, s. 179.

Taboł S., Uwagi o myśli pedagogicznej Sokratesa, „Kultura i Wychowanie” 2012, 4(2), s. $49-62$.

Wojaczek M., Aniołkowe mamy. Historie kobiet, które poronity. Porady ekspertów, Wydawnictwo M, Warszawa 2009.

Worth J., Zawołajcie położna, przeł. M. Kisiel-Małecka, Wydawnictwo Literackie, Warszawa 2014.

Zurzycka P., Radzik T., Medycyna narracyjna - zarys problematyki, „Problemy Pielęgniarstwa” 2015, nr 23(3), s. 428-432. 


\section{Źródła internetowe}

http://www.vivatporod.pl/pl,strona_glowna

Naturalnie po cesarce - grupa wsparcia, https://www.facebook.com/groups/5977 18530295741/

\#lepszy poród, wpis anonimowy

\section{A B S T R A C T}

\section{Tell me... Narration in the experience of pregnancy, childbirth and loss of a child}

The article is a reflection on the use of elements of narrative medicine in midwifery. It presents fragments of perinatal narratives in various types of texts (also in belles-lettres) which can be used by women experiencing difficulties related to the pregnancy and childbirth and are a great material in the teaching of midwifery adepts. The article also describes the value of narrative medicine in relation to the work of midwives.

KEY WORDS: midwifery, narrative medicine, storytelling

\section{A B S T R A K T}

\section{„Opowiedz mi...”. Narracja w doświadczeniach ciąży, porodu i straty dziecka}

Główną treść artykułu stanowią refleksje dotyczące wykorzystania elementów medycyny narracyjnej $\mathrm{w}$ położnictwie. Opracowanie zawiera fragmenty narracji okołoporodowych $w$ różnych typach tekstów (w tym w literaturze pięknej), które mogą pomóc kobietom w przeżywaniu ciąży, porodu i wczesnego okresu poporodowego, a także stanowią materiał do wykorzystania w nauczaniu adeptów sztuki położniczej. Autorki omówiły również przydatność medycyny narracyjnej w kształceniu i w pracy położnych.

SŁOWA KLUCZOWE: położnictwo, medycyna narracyjna, storytelling 
Halina Kulik

Śląski Uniwersytet Medyczny

Józefa Dąbek

Śląski Uniwersytet Medyczny

\section{„Okaleczona kobiecość". $\mathrm{Z}$ pamiętników kobiet $\mathrm{z}$ niepełnosprawnościami}

Na doświadczanie przez kobiety konsekwencji niepełnosprawności po raz pierwszy zwrócono uwagę pod koniec lat 70. ubiegłego wieku ${ }^{1}$. Dostrzeżono wówczas problemy, z którymi kobiety z niepełnosprawnościami spotykają się w takich dziedzinach życia, jak: relacje międzyludzkie, edukacja, zatrudnienie, seksualność, macierzyństwo. Kontekstem tych rozważań były także stereotypy, powtarzane wielokrotnie w mediach, które znacznie utrudniają, a czasem wręcz uniemożliwiają pogodzenie roli społecznej kobiety i osoby dotkniętej niepełnosprawnością. Już wówczas stwierdzono wysoki stopień wykluczenia społecznego odczuwanego przez kobiety z niepełnosprawnością na rynku pracy, skutkujący ich gorszą sytuacją pod względem ekonomicznym, społecznym i psychologicznym w porównaniu zarówno do mężczyzn z niepełnosprawnościami, jak i do pełnosprawnych kobiet ${ }^{2}$.

Lidia Marszałek podkreśla, że kobiety z niepełnosprawnością są podwójnie dyskryminowane. Powodem owej dyskryminacji jest $z$ jednej strony fakt bycia osobą z niepełnosprawnością, z drugiej zaś - bycie kobietą. Dostrzeganie „kobiecości” kobiet z niepełnosprawnościami staje się w społecznej świadomości dodatkowym czynnikiem uzasadniającym szereg uprzedzeń związanych z podejmowaniem przez nie ról kobiety, żony i matki:

${ }^{1}$ Jo Campling, Better Lives for Disabled Women, London 1979; Jo Campling, Images of Ourselves: Women with Disabilities Talking, London 1981.

${ }^{2}$ Michelle Fine, Adrienne Asch, Women with Disabilities: Essays in Psychology, Culture, and Politics, Philadelphia 1988; Susan Londsale, Women and Disability: The Experience of Physical Disability among Women, London-Basingstoke 1990. 
W rzeczywistości nie są one bowiem percypowane społecznie w kategorii przynależności do płci, odbiera im się społecznie prawo do realizowania się $\mathrm{w}$ kobiecych rolach, zezwalając jedynie na funkcjonowanie w obrębie tożsamości osoby niepełnosprawnej, z czym związane są najczęściej kolejne działania zmierzające do ograniczania ich praw i blokowania zaspokajania potrzeb $^{3}$.

Zrozumienie wielowymiarowości sytuacji osobistej i społeczno-kulturowej tych kobiet jest niezwykle trudne i wymyka się prostym interpretacjom. Skupianie się wyłącznie na medycznym aspekcie zaburzeń bądź na istniejących barierach i uprzedzeniach społecznych kryje w sobie podejście redukcjonistyczne, pomijające bądź ignorujące niektóre aspekty omawianego zagadnienia.

Celem niniejszego artykułu jest zwrócenie uwagi na treści poruszane $\mathrm{w}$ pamiętnikach i wspomnieniach kobiet $\mathrm{z}$ różnymi rodzajami niepełnosprawności, skupiające się wokół trzech kręgów tematycznych, którymi są: dzieciństwo i szkoła, bycie kobietą niepełnosprawną oraz aktywność zawodowa, sportowa i społeczna. Chciałybyśmy zaznaczyć, że podjęłyśmy próbę refleksji nad wybranymi tekstami nie z pozycji profesjonalnych badaczek literatury (w tym literatury autobiograficznej), tylko jako przedstawicielki zawodów medycznych, które dostrzegają w tych tekstach ogromną wartość poznawczą i edukacyjną, uwrażliwiającą nas na przeżycia osób z ograniczoną sprawnością i wzbogacającą nasze codzienne doświadczenie pracy z pacjentami ${ }^{4}$.

${ }^{3}$ Lidia Marszałek, Niepetnosprawność, kobiecość, rodzina, Warszawa 2006, s. 10.

${ }^{4}$ Zdajemy sobie sprawę, że specjaliści z dziedziny literaturoznawstwa mogą odebrać nasze przemyślenia jako powierzchowne. W momencie przygotowywania publikacji dokonałyśmy zaledwie wstępnego rozpoznania tego obszaru badawczego. Stopniowo zbliżamy się do dziedziny pod wieloma względami dla nas nowej, docieramy do kolejnych książek, zapisków kobiet dotkniętych doświadczeniem niepełnosprawności, które oczarowują nas - przedstawicielki środowiska medycznego - głębią przemyśleń i trafnością ocen. W ostatnich latach na rynku wydawniczym pojawiło się kilka pozycji książkowych mających charakter autobiograficzny, pamiętnikarski i wspomnieniowy, których autorkami były kobiety niepełnosprawne. Oprócz publikacji uwzględnionych w naszym artykule są to także m.in.: Mirka Jaworska, Syndrom czerwonej hulajnogi, Warszawa 2013; Anna Bartuszek, BeStia ujarzMiona. Moja walka $z$ choroba, Warszawa 2010; Jana Frey, W ciemności, Warszawa 2004; Jodi Picoult, Krucha jak lód, Warszawa 2010; Helen Keller, Historia mojego życia, Warszawa 1978; Fiona Bollag, Wyszłam z krainy ciszy. Historia głuchoniemej dziewczyny, która odzyskata stuch, Warszawa 2007; Katarzyna Zychla, Dziewczynka tanczaca $z$ wiatrem, Katowice 2007; Barbara Mujica, Frida, Warszawa 2015; Hanna Pasterny, Tandem w szkocka 
Omawiane teksty pochodzą z kilku źródeł. Część z nich to plon dwóch konkursów na pamiętniki kobiet z niepełnosprawnościami; są to zapiski opublikowane $\mathrm{w}$ dwóch tomach: Cierpieniem pisane. Pamiętniki kobiet niepetnosprawnych ${ }^{5}$ oraz Moje Kilimandżaro. Losy niepetnosprawnych - wspomnienia ${ }^{6}$. Interpretacji poddałyśmy również wspomnienia uczestniczek wyprawy osób z niepełnosprawnościami na Kilimandżaro - ich losy i doświadczenia opisała Małgorzata Wach w bogato ilustrowanym albumie Każdy ma swoje Kilimandżaro ${ }^{7}$. Zwróciłyśmy także uwagę na treść książek: Katarzyny Rosickiej-Jaczyńskiej - Otówek ${ }^{8}$, Hanny Pasterny - Moje podróże w ciemno ${ }^{9}$ oraz Moniki Kuszyńskiej i Katarzyny Przybyszewskiej - Drugie życie ${ }^{10}$. Choć teksty te stanowią zbiór dość różnorodny pod względem formy, łączy je postać autorek-bohaterek: są to kobiety opisujące swoje doświadczenie niepełnosprawności.

Warto na początek wspomnieć o okolicznościach powstania wybranych przez nas tekstów i pokazać próbkę ich treści. W 1990 roku Uniwersytet Marii Skłodowskiej-Curie w Lublinie, przy współpracy z Oddziałem Lubelskim Polskiego Towarzystwa Walki z Kalectwem, ogłosił konkurs na pamiętniki kobiet $z$ niepełnosprawnościami. Ogółem nadesłano sto pięćdziesiąt sześć prac. Najmłodsza autorka wspomnień miała dwadzieścia lat, najstarsza - osiemdziesiąt. Wśród motywów udziału w konkursie dominowało pragnienie opowiedzenia zdrowym i sprawnym ludziom o tym, co jest najtrudniejsze i najbardziej bolesne dla osób z ograniczoną sprawnością. Autorki czuły także potrzebę udowodnienia, że człowiek z niepełnosprawnościami nie jest niesprawny w ogóle. Część nadesłanych prac została opublikowana w 1991 roku w tomiku Cierpieniem pisane. Pamiętniki kobiet niepetnosprawnych. Maria Chodkowska we wstępie do zebranych wspomnień napisała:

Życie kobiet niepełnosprawnych jest bardzo trudne, w niektórych przypadkach tragiczne. Czytając ich pamiętniki, nie sposób jednak oprzeć się wrażeniu, że wiele spośród nich czuje się szczęśliwymi. Pogodziły się z kalectwem,

kratkę, Katowice 2010. Widzimy w tej literaturze wartość terapeutyczną (dla chorych, zdrowych, lekarzy) i na nią chciałybyśmy zwrócić szczególną uwagę.

${ }^{5}$ Cierpieniem pisane. Pamiętniki kobiet niepetnosprawnych, Olsztyn 1991.

${ }^{6}$ Moje Kilimandżaro. Losy niepetnosprawnych - wspomnienia, Poznań 2008.

${ }^{7}$ Małgorzata Wach, Każdy ma swoje Kilimandżaro, Kraków 2008.

${ }^{8}$ Katarzyna Rosicka-Jaczyńska, Otówek, Łódź 2011.

${ }^{9}$ Hanna Pasterny, Moje podróże w ciemno, Katowice 2015.

${ }^{10}$ Monika Kuszyńska, Katarzyna Przybyszewska, Drugie życie, Warszawa 2015. 
cierpią, ale nie poddają się. Walczą jak potrafią o prawo do godnego życia, na co dzień udowadniają swoją wartość. Przeżywają chwile załamań, ale potrafią je przezwyciężać. Gdzie zatem tkwi źródło ich siły, zarówno fizycznej, jak i duchowej? [...]

Możliwość ofiarowania Ojcu Świętemu swoich wspomnień, przeżytych cierpień i upokorzeń, doznanych porażek i odniesionych zwycięstw, wszystkie laureatki konkursu uznały za wielkie wyróżnienie ${ }^{11}$.

W 2008 roku ukazała się książka Moje Kilimandżaro. Losy niepetnosprawnych - wspomnienia. Była ona pokłosiem konkursu literackiego dla osób z niepełnosprawnościami „Moje losy”, zorganizowanego w 2006 roku przez poznański miesięcznik „Filantrop Naszych Czasów” i Wielkopolski Związek Inwalidów Narządu Ruchu. Publikacja zawiera krótkie autobiografie, pamiętniki i wspomnienia kobiet, a jedna z prac ma charakter internetowego bloga. Antologię wspomnień krótkim wstępem opatrzyła Irena Obuchowska, podkreślając ich szczególną wartość poznawczą i edukacyjną:

Książka ta jest dialogiem słabości ciała z mocą woli. Znajdujemy w niej piękno życia pomimo bólu, niepełnosprawności i zwątpień. [...] Warto w świetle tej książki spojrzeć na własne życie, przemyśleć swoje trudy i sposoby radzenia sobie $z$ nimi. Taka refleksja może niekiedy wpłynąć na ocenę własnego życia i zmianę hierarchii wartości.

Sądzę też, że książka ta powinna stać się szkolną lekturą dla dorastającej młodzieży, dla której może być pomocna w poszukiwaniu swojej tożsamości i sensu życia. I z całą pewnością powinni się z nią zapoznać lekarze pediatrzy, pedagodzy, psychologowie oraz pracownicy socjalni ${ }^{12}$.

Książka Każdy ma swoje Kilimandżaro to relacja z wyprawy osób z niepełnosprawnościami na najwyższą górę Afryki, przeplatana wspomnieniami jej uczestników. Organizatorem wyprawy była Fundacja „Mimo Wszystko” Anny Dymnej, polskiej aktorki i działaczki na rzecz osób z niepełnosprawnościami. Wyprawa na Kilimandżaro, zorganizowana dzięki hojnemu wsparciu sponsorów, odbyła się w dniach 27 września-10 października 2008 roku. Brali w niej udział niepełnosprawni podopieczni Fundacji, wśród których były dwie kobiety: Angelika Chrapkiewicz-Gądek, cierpiąca od trzeciego roku życia na dystrofię mięśniowa, i Katarzyna Rogowiec, wielokrotna medalistka mistrzostw świata w biathlonie. Sprawni uczestnicy

11 Maria Chodkowska, Słowo wstępne, w: Cierpieniem pisane..., op. cit., s. 16-17.

12 Moje Kilimandżaro..., op. cit., s. 5. 
wyprawy zastępowali niepełnosprawnym ich niesprawne nogi, ręce i niewidzące oczy.

Autobiograficzna książka Katarzyny Rosickiej-Jaczyńskiej, zatytułowana Otówek - ze względu na treść i zawarty przekaz - przez jedną z czytelniczek nazwana została „życiownikiem”:

[...] to nie pamiętnik chorej kobiety, a „życiownik”, który powinien przeczytać każdy, kto żyje, pędząc między praca, obowiązkami, komu na codzienne życie brakuje doby. Katarzyna Rosicka w bardzo prosty i cudowny sposób dotknęła chyba wszystkich aspektów naszego życia, począwszy od kobiecości, którą mimo strasznej choroby zachowała, poprzez uczucia między mężczyzną a kobietą, na relacjach przyjacielskich, rodzinnych i rodzicielskich skończywszy. Pełna życia, piękna kobieta rozwodzi się z mężem, ojcem swojej trójki dzieci, który w pewnym momencie najzwyczajniej przestaje jej imponować, rzuca się w wir pracy i niezbyt udanych życiowych wyborów, żeby po krótkim czasie dowiedzieć się o śmiertelnej chorobie ${ }^{13}$.

Hanna Pasterny, niewidoma od urodzenia podróżniczka i autorka książek, bystra „obserwatorka” ludzkich zachowań, często wspomina o reakcjach otoczenia na jej niepełnosprawność:

Niekiedy eksperymentuję i badam reakcje pasażerów. Podczas jednej z podróży do Budapesztu dosiadłam się do przedziału, w którym parę osób rozmawiało po angielsku. Po dłuższej chwili zapytałam dwie dziewczyny (jak się okazało, studentki pedagogiki), czy są z Turcji?. Zaskoczyło je to i koniecznie chciały się dowiedzieć, skąd to wiem. Wyjaśniłam, że osoby niewidome mają szósty zmysł i gdy kogoś spotykają, od razu wiedzą, z jakiego jest kraju. Początkowo były nieco zaskoczone, ale potem mi uwierzyły. Przerażające, że przyszłe nauczycielki dały się nabrać na taką bzdurę ${ }^{14}$.

Ciekawość współpasażerów wzbudza nie tylko brajl. Pewnego razu, gdy wysiadałam $z$ pociągu $\mathrm{w}$ belgijskim Liège, jakiś chłopak zaproponował, że kawałek mnie odprowadzi. Zaintrygował go mój elektroniczny mówiący notatnik Kajtek, w którym robiłam zapiski. Jest w kształcie prostokąta i ma brajlowską klawiaturę. Chłopak koniecznie chciał się dowiedzieć, co to za nowa gra elektroniczna, jak działa i za ile można ją kupić15.

${ }_{13}$ Opinie; http://lubimyczytac.pl/ksiazka/113268/olowek/opinia z dnia 18 czerwca 2013 roku [dostęp 2.10.2018].

${ }^{14}$ Hanna Pasterny, Moje podróże..., op. cit., s. 16.

${ }^{15}$ Ibidem, s. 17. 
Każda $z$ uwzględnionych $w$ artykule publikacji jest autentyczną ,"historią jednego życia". Ma bezcenną wartość poznawczą, ponieważ obrazuje życie $z$ niepełnosprawnością $\mathrm{w}$ różnych okolicznościach $\mathrm{i}$ warunkach. Niezależnie od tego, skąd pochodza, gdzie mieszkają i jak żyją ich autorki-bohaterki, książki te pokazują, jak kobiety nie tylko przezwyciężają własne słabości, lecz także mierzą się z barierami mentalnymi, $z$ utrwalonymi w społecznej świadomości mitami i stereotypami na temat niepełnosprawności. Pamiętniki i wspomnienia pisane są prostym językiem, czasem wzruszają, momentami bawią do łez, zawsze jednak skłaniają do głębokiej refleksji. Bez zbędnej demagogii i patosu mówią nie tylko o bezmiarze ludzkiego cierpienia, lecz także (a może przede wszystkim) o niewiarygodnej wytrwałości w walce o sens życia, godność i prawa człowieka, jak również o marzenia i własny kawałek nieba. W tej nierównej walce olbrzymie znaczenie ma obecność drugiego czlowieka, który w najtrudniejszych momentach daje wsparcie. Jest o tym mowa w przedstawionym niżej fragmencie:

Urodziłam się co najmniej o trzy lata za wcześnie. Wtedy jeszcze nie umiano w powszechnej praktyce rozpoznawać we wczesnym okresie życia dziecka choroby, z którą przyszłam na świat - mózgowego porażenia dziecięcego. [...] Urodziłam się $\mathrm{w}$ nieodpowiednim miejscu. Przyszłam na świat w niedużym prowincjonalnym mieście. Tutaj wszystko dociera z opóźnieniem. Mieszkam całe życie na wsi. To jest specyficzne środowisko, podporządkowujące swą egzystencję wymogom ziemi, gospodarstwa i pracy, zaś wszelkie odmienności albo zwalczaja, albo traktują obojętnie. [...] Urodziłam się jednak pod szczęśliwą gwiazdą. W najtrudniejszych chwilach zawsze znalazł się człowiek, który mi pomóg1 ${ }^{16}$.

W osobistych narracjach znajdujemy szeroką wykładnię i ocenę rzeczywistej sytuacji ich autorów. Poznanie narracji niepełnosprawności pomaga odbiorcom (zwłaszcza osobom, które nie mają takich doświadczeń) zrozumieć złożoność sytuacji osobistej i społeczno-kulturowej osób z niepełnosprawnościami. Wykorzystanie narracji w praktyce klinicznej (oraz w dydaktyce) poza aspektem czysto informacyjnym daje możliwość szerokiego (wykraczającego poza sumę procesów biomedycznych czy jednostek chorobowych) spojrzenia na pacjenta jako na nierozerwalną

16 To, że urodziłam się chora, dało mi głębsze spojrzenie na życie, w: Cierpieniem pisane..., op. cit., s. 22-24. 
całość: biologiczną, psychologiczną i duchową, pozostającą w interakcji $z$ otoczeniem społecznym i kulturowym.

Na znaczenie narracji pacjenta w medycynie zwrócono uwagę stosunkowo niedawno ${ }^{17}$. Koncepcję medycyny narracyjnej stworzyła Rita Charon, z zawodu lekarka internistka, profesor Uniwersytetu Columbia. Medycyna narracyjna stanowi humanistyczną refleksję nad praktyką medyczną i jest filozofią relacji terapeutycznej. Fundamentalne znaczenie przypisuje się w niej indywidualnym historiom chorych; przyjmuje się, że doświadczenia pacjentów i ich bliskich stanowią integralny element utrzymania zdrowia, jak również postawy i zachowań w chorobie i niepełnosprawności. Dzięki narracji można pozyskać wiele danych, istotnych $\mathrm{w}$ procesie diagnozowania, które mogłyby zostać pominięte podczas standardowego wywiadu klinicznego. Charon zaproponowała stworzenie nowej koncepcji medycyny, którą nazwała Narrative Evidence-Based Medicine (w skrócie NEBM). Jej połączenie z możliwościami medycyny opartej na dowodach naukowych, czyli Evidence-Based Medicine (w skrócie EBM), pozwala lepiej poznać pacjentów i ich bliskich oraz zwiększyć skuteczność terapii. Uwzględnienie komponentów narracyjnych w praktyce klinicznej przekłada się także na wzrost poczucia podmiotowości pacjenta ${ }^{18}$.

\section{Dzieciństwo i szkoła}

Okres dzieciństwa autorek omawianych przez nas pamiętników był bardzo różny, ale wspólną cechą wszystkich zapisków jest wspomnienie cierpienia obcego dzieciom zdrowym. Niepełnosprawność w czasie bycia dzieckiem wiązała się nie tylko $z$ bólem fizycznym: bolesnymi zabiegami operacyjnymi i nie mniej bolesną rehabilitacją, bólem towarzyszącym zwykłym codziennym czynnościom i niemalże każdemu ruchowi. Często do uszu niepełnosprawnych dziewczynek dobiegały słowa: „biedne dziecko”, „nieszczęśliwa dziewczynka". Ta litość i związane z nią upokarzające poczucie inności bolały bardziej niż chore biodro, nogi czy kręgosłup, a okrutne słowa, gesty i zachowania brutalnie ranily i dodatkowo okaleczały. Nie wszystkie autorki wspomnień doznawały w dzieciństwie miłości rodziców, ich opieki i troski, której tak bardzo potrzebowały. Nie wszystkie mogły

17 Patrycja Zurzycka, Teresa Radzik, Medycyna narracyjna - zarys problematyki, „Problemy Pielęgniarstwa” 2015, s. 428-432.

18 Ibidem, s. 429. 
liczyć na pomoc rodziców w usamodzielnieniu się i w przygotowaniu do odgrywania ról społecznych i wypełniania zadań przypisywanych kobiecie. Wiele kobiet wspomina również, że nie mogły się uczyć. Brak zgody rodziców na kontynuowanie nauki nie zawsze wynikał z ich negatywnego stosunku do dziecka; taka decyzja opiekunów często była konsekwencją błędnego przekonania, że poprzez zatrzymanie dziecka $\mathrm{w}$ domu zaoszczędzą mu dodatkowych stresów, upokorzeń i cierpień.

Niepełnosprawność, choroba przewlekła bądź odmienność zachowania dziecka na tle rówieśników jest dla rodziców bez wątpienia wielkim wyzwaniem i sprawdzianem. Postawy i zachowania rodziców bądź opiekunów wobec inności dziecka oraz konieczności podjęcia nad nim opieki są zróżnicowane, a w dużym stopniu zależą od reakcji i pomocy otoczenia. Liczne badania potwierdzają, że najbardziej pożądany model opiekuńczy wyraża się w postawie opisanej słowami: „ponieważ cię kocham, chcę i zrobię wiele, by ci pomóc, więc nauczę się, jak i co mam robić, byś był samodzielny i aktywny"19.

Okres adolescencji, nazywany w literaturze wiekiem ryzyka lub kryzysów, jest etapem przejściowym pomiędzy dzieciństwem a dorosłością, w którym koncentrują się problemy dorastania psychospołecznego i dojrzewania psychoseksualnego. Przezwyciężenie ich zależy od ukształtowanej wcześniej podstawy tożsamości, własnej aktywności, jak również od konstruktywnego wchodzenia w nowe role społeczne. Wiele osób z niepełnosprawnościami nie potrafi jednak poradzić sobie z odnalezieniem się $\mathrm{w}$ przypisanych im rolach. Na wspierającą rolę rodziny w zmaganiu się adolescenta z niepełnosprawnością zwraca uwagę Franciszek Wojciechowski:

Rodzina jest nieodwołalnie pierwszym środowiskiem, w którym ma miejsce zmaganie się z niepełnosprawnością, począwszy od dostrzeżenia pierwszych niepokojących objawów, przez zaprzeczenie i poszukiwanie dalszej diagnozy oraz skutecznych form wsparcia i pomocy ${ }^{20}$.

Z przeprowadzonych przez autora badań dotyczących sytuacji życiowej dorastającej młodzieży z niepełnosprawnościami i ich rodzin wynikało, że prawie wszyscy rodzice mieli trudności z pogodzeniem się ze stanem ich

${ }^{19}$ Zofia Kawczyńska-Butrym, Wyzwania rodziny: zdrowie, choroba, niepetnosprawność, starość, Lublin 2008, s. 137.

${ }^{20}$ Franciszek Wojciechowski, Niepetnosprawność, rodzina, dorastanie, Warszawa 2007, s. 9. 
dziecka. Emocje przez nich przejawiane były zróżnicowane: od deklarowanej akceptacji i zrozumienia, przez uczucia zawodu i rozczarowania, po przyjmowanie postaw unikających i wypierających. Wielu rodziców wykazywało, zwłaszcza w zakresie górowania nad dzieckiem, postawy niepożądane: nadmierną koncentrację uczuciową i bezradność oraz zachowywanie nadmiernego dystansu $\mathrm{w}$ kontakcie $\mathrm{z}$ dzieckiem. Obciążenie psychiczne, na jakie byli stale narażeni rodzice, skutkowało spadkiem odporności na stres i pogorszeniem relacji $z$ dzieckiem ${ }^{21}$.

Wśród analizowanych wspomnień są fragmenty, z których wyłania się nieco inny, lepszy obraz rodziny i dzieciństwa. Angelika Chrapkiewicz-Gądek wspominała swoje dzieciństwo jako „jedno wielkie szaleństwo"22. Jej rodzice w pełni realizowali wspomniany już optymalny model opiekuńczy, okazywali jej miłość i akceptację, a jednocześnie sami akceptowali siebie w roli jej opiekunów i czerpali z tej roli satysfakcję ${ }^{23}$. Rozważna troska o przyszłość córki powodowała, że rozsądnie dawali jej dużo swobody w podejmowaniu różnorodnych decyzji, a przy tym konsekwentnie mobilizowali ją do podejmowania wysiłków w kierunku pokonywania barier związanych z ograniczoną sprawnością. Doskonałą ilustracją ich postawy wychowawczej są cytowane niżej fragmenty wspomnień Angeliki:

Nikt mnie nie zakręcał w słoiku. Chodziłam po drzewach, jeździłam na rowerze. Do dziś mam oba kolana zryte, bo się ciągle wywalałam. Ale wstawałam, lazłam na górkę i znowu jechałam. Tata z mamą tylko patrzyli przez okno. Jak leżałam, to mama wychodziła przed dom, patrzyła, czy się ruszam, i wołała do taty: „Czy mógłbyś pozbierać swoją córkę?”. Albo: „Teraz ty ją opatrujesz”24.

Od zawsze byłam jego córeczką. Gdy czasem siadam i mówię, że coś się nie uda, on odpowiada: "Jak to się nie uda? Będziesz to robić trochę dłużej, może sobie tyłek stłuczesz, ale się uda. Zobaczysz". I to jest prawda. Pamiętam jak wróciłam z sanatorium do świeżo wybudowanego domu. Tata powiedział, że mój pokój jest na piętrze. Zrobił mi takie specjalne dwie poręcze, żebym mogła się dobrze chwycić i kazał mi się tam wdrapywać. Któregoś dnia byłam już bardzo zmęczona i wypaliłam: „Tato, czy ty nie widzisz, jakie to jest dla mnie trudne?!”. „Może i trudne, ale nie niemożliwe”25.

21 Ibidem, s. 223-226.

22 Małgorzata Wach, Każdy ma..., op. cit., s. 19.

23 Zofia Kawczyńska-Butrym, Wyzwania rodziny..., op. cit., s. 137.

${ }^{24}$ Małgorzata Wach, Każdy ma..., op. cit., s. 19.

25 Ibidem, s. 21-24. 
Katarzyna Rogowiec, która w wieku trzech lat straciła obie ręce, wspominała o tym, jak jej rodzice starali się, aby mogła chodzić do szkoły i uczyć się wraz z innymi dziećmi. Tak opowiadała o dobrych chęciach mamy i o swoich zmaganiach $z$ zajęciami manualnymi:

Mama długo walczyła, żebym mogła pójść do normalnej szkoły. [...] Nie dziwię się nauczycielom. Bali się, bo nie mieli wcześniej uczennicy bez rąk. [...] Skąd mogli wiedzieć, że się nauczę pisać, rysować, odrabiać lekcje i lepić ludki z plasteliny? Wiem, że mama zawarła ciche porozumienie z niektórymi nauczycielkami, że będzie mi pomagać. Tak było między innymi w przypadku prac ręcznych. Mama oczywiście chciała to zrobić za mnie. Jak się o tym dowiedziałam, to w złości wymusiłam na niej, żeby nauczyła mnie wyszywać. Potem zamknęłam się w pokoju, wzięłam igłę, nitkę, kawałek płótna i zaczęłam szyć zębami. Miały być kwiatki, wyszły jakieś chińskie znaczki, ale to były moje znaczki. Nie wiem, jaką ocenę wtedy dostałam, ale ona też była moja. Przez te zmagania $z$ igłą zniszczyłam sobie zęby, jednak nie żałuję ${ }^{26}$.

O wielkiej miłości rodziców pisały również autorki innych wspomnień. Jedna z nich podkreślała, że rodzice od chwili dostrzeżenia pierwszych niepokojących objawów w jej stanie zdrowia dokładali wszelkich starań, aby odzyskała sprawność, a przy tym okazywali zrozumienie, pełną akceptację i miłość:

Rodzice choć udręczeni moim losem nigdy nie poprzestawali w staraniach, by mi pomóc, ciągle gdzieś prosili o pomoc i starali się wszelkimi siłami, by dotrzeć jak najwcześniej do specjalistów. Okazywali mi zawsze uśmiech i radość z każdego przeżytego dnia ${ }^{27}$.

Autorka cytowanej niżej wypowiedzi zwróciła uwagę na wartość wykształcenia $\mathrm{w}$ jej rodzinie. Pomimo trudnej sytuacji materialnej rodzice starali się zapewnić wykształcenie wszystkim z sześciorga dzieci:

Urodziłam się we właściwej rodzinie. Przyszłam na świat jako szóste dziecko w rodzinie, która wysoko ceniła wykształcenie. [...]. Wszyscy się uczyli. By mieć ode mnie spokój, nauczyli mnie w wieku pięciu lat czytać i pisać i zadawali mi różne „lekcje”28.

\footnotetext{
${ }^{26}$ Ibidem, s. 70-71.

27 Każde cierpienie ma swój sens, w: Cierpieniem pisane..., op. cit., s. 19.

${ }^{28}$ To, że urodziłam się chora dało mi głębsze spojrzenie na życie, w: ibidem,
} s. $22-23$. 
Niektóre wspomnienia lat dzieciństwa obejmują okres wojny i okupacji hitlerowskiej, inne przypadają na trudny czas powojenny, w którym najistotniejsza była walka o przetrwanie, a brak możliwości leczenia i rehabilitacji chorego dziecka skutkował nieodwracalnymi zmianami w stanie jego zdrowia. Ilustracją takich historii jest to wspomnienie:

Urodziłam się w czasie wojny w Czechosłowacji, gdzie moi rodzice wyjechali przed wojną za pracą. Ojciec mój w czasie tej wojny zginął w obozie, a ja zostałam od dziecka inwalidką na uszy. Niemcy zabrali nam całe mienie, a nas (matkę z trojgiem dzieci) wyrzucili z naszego mieszkania. Zamieszkaliśmy wówczas w starej szopie i ja z zimna zaczęłam chorować na uszy. Matka nie mogła mnie leczyć, gdyż była wojna, a po skończonej wojnie, gdy wróciła z nami do Polski i zaczęła mnie leczyć, choroba była już tak posunięta, że musiałam mieć operację ucha, gdyż groziła mi śmierć. Wtedy lekarze powiedzieli matce, że ratują mi życie, ale słyszeć na to ucho nie będę ${ }^{29}$.

Niezależnie od okoliczności i czasu powstania niepełnosprawności niezwykle trudno jest ją zaakceptować samej osobie niepełnosprawnej. Nie można jej wymazać z pamięci. Od momentu pojawienia się zaczyna definiować całe życie. Monika Kuszyńska, piosenkarka i autorka tekstów, która w 2006 roku w wyniku wypadku samochodowego doznała uszkodzenia rdzenia kręgowego, pisała tak:

Była niedziela 28 maja 2006 roku. Ostatni dzień mojego życia. Tamtego życia ${ }^{30}$.

Wciąż nie czułam nóg i teraz zaczęło mnie to niepokoić. [...] Dziękuję Ci Boże, że żyję! Wiem, nie jest dobrze, ale żyję! Będzie lepiej, musi być. [...] Miałam nadzieję $e^{31}$.

Swoje wspomnienia zakończyła słowami: „Nadziei jednak nie porzuciłam. Zawsze warto ją mieć. Bez względu na wszystko. Moja historia się przecież jeszcze nie kończy"32.

Angelika Chrapkiewicz-Gądek wspominała, że długo nie mogła pogodzić się z ograniczeniami sprawności i starała się wszelkimi możliwymi sposobami ją ukrywać:

${ }^{29}$ Głęboka wiara w Boga pozwoliła mi przetrwać, w: Cierpieniem pisane..., op. cit., s. 49.

${ }_{30}$ Monika Kuszyńska, Katarzyna Przybyszewska, Drugie życie..., op. cit., s. 11.

${ }^{31}$ Ibidem, s. 18-21.

${ }^{32}$ Ibidem, s. 308. 
Długo nie chciałam się przyznać, że jest ze mną źle. Wracałam ze szkoły cztery godziny. Potokiem, bo była krótsza droga. W domu kłamałam, że były dodatkowe lekcje, albo że byłam u kolegi coś odpisać. W końcu się wydało. Siedziałam na Drodze do Rajów i płakałam, bo miałam kawał pod górę. Sąsiad mnie zobaczył i przywiózł do domu. Załatwił mnie. Musiałam zacząć siadać na wózek. W wieku osiemnastu lat nie mogłam się już z nim rozstać. Ale co dałam radę wcześniej przejść sama, tego nikt mi nie odbierze ${ }^{33}$.

Katarzynie Rogowiec bardzo zależało na tym, żeby wyglądać jak inne dziewczyny. Brak rąk maskowała więc ubraniami z długimi rękawami:

W trzeciej klasie postanowiłam, że wrócę do protez. W czasie wakacji pojechałam z mamą do kliniki w Poznaniu, gdzie zrobili mi całkiem ładne „ręce”. Tak przynajmniej myślałam. Na początku roku szkolnego spotkałam się z jednym z kolegów, który popatrzył na mnie i powiedział: „Boże, Kaśka, ty wyglądasz jak Rambo”. Wtedy ściągnęłam protezy na dobre. Nigdy potem nie chciałam do nich wrócić. Nie będę żadnym Rambo. Nie mam rąk i koniec. Niczym tego nie zakryję. Niech się świat dziwi, gapi, pyta. Nie mam! Nic na to nie poradzę $e^{34}$.

Dla prawidłowego toku kształtowania tożsamości kobiet $\mathrm{z}$ niepełnosprawnością bardzo ważna jest możliwość kształcenia na wszystkich dostępnych szczeblach. Uzyskanie wyższego wykształcenia pociąga za sobą szereg pożądanych następstw: warunkuje pełniejszą realizację zadań rozwojowych i daje poczucie, że niepełnosprawność nie determinuje wszystkich sfer życia. Przede wszystkim jednak wykształcenie zwiększa szanse na zdobycie ciekawszej, lepiej płatnej pracy, gwarantującej niezależność ekonomiczną ${ }^{35}$. Obecnie wiele kobiet $z$ różnego rodzaju niepełnosprawnościami idzie na studia i zdobywa wyższe wykształcenie. Katarzyna Rogowiec w taki sposób wspominała swój egzamin wstępny na wyższą uczelnię oraz rodzące się plany na dalszy rozwój osobisty:

Po zdaniu matury złożyłam dokumenty na Akademię Ekonomiczną w Krakowie (zawsze byłam niezła $z$ matematyki). Pamiętam jak po pisemnym egzaminie wstępnym podszedł do mnie jeden z profesorów i powiedział: „Dziecko drogie, a czemu ty nie zdawałaś egzaminu indywidualnie? Miałabyś jakieś ułatwienia”.

${ }^{33}$ Małgorzata Wach, Każdy ma..., op. cit., s. 20.

34 Ibidem, s. 73-73

35 Lidia Marszałek, Niepetnosprawność, kobiecość, rodzina..., op. cit., s. 189. 
Ułatwienia? Nie wiedziałam, że tak można. Był egzamin, to przyszłam. [...] Wpadłam też na pomysł, że zrobię kurs pilota wycieczek zagranicznych. Gnało mnie w świat, najlepiej do Włoch ${ }^{36}$.

\section{$\mathrm{W}$ roli kobiety $\mathrm{z}$ niepełnosprawnością}

Niezależnie od cech społeczno-demograficznych czy stanu zdrowia człowiek jako istota społeczna pragnie kontaktu z innymi ludźmi, zaspokojenia potrzeby przynależności do grupy oraz miłości i uznania. Maria Chodkowska pisała: „Ograniczenie sprawności fizycznej nie powoduje zaniku odczuwanych potrzeb, które mogłyby być zaspokajane przez małżeństwo, tak seksualnych, jak i psychospołecznych"37. Lidia Marszałek, badając problem społecznego funkcjonowania kobiet $z$ niepełnosprawnością, zwłaszcza w zakresie ról małżeńskich i macierzyńskich, ustaliła, że kobiety te obawiają się podejmowania ról rodzinnych, ponieważ odczuwają brak kompetencji w tym zakresie. Obawy te były u badanych kobiet tym większe, im większa była ich niepełnosprawność i im wcześniejszy czas jej powstania. Autorka ustaliła, że poczucie kobiecości pozostaje $\mathrm{w}$ silnym związku z chęcią podejmowania i realizacji przez kobiety $z$ niepełnosprawnością ról przypisywanych ich płci, a doświadczenia roli żony i matki wyraźnie wpływają na wzrost ich identyfikacji ze społecznym standardem kobiecości. Skuteczne i pozytywne wypełnianie ról rodzinnych przez kobiety z niepełnosprawnością sprzyja również przełamywaniu stereotypów, daje poczucie szczęśliwego życia, wbrew społecznym oczekiwaniom, ale zgodnie $z$ własnymi aspiracjami ${ }^{38}$.

Zdrowe, pełnosprawne kobiety od najmłodszych lat przygotowywane są do roli żony i matki: obserwują zachowania innych kobiet (matki, babci), a nawet częściowo uczestniczą w wykonywaniu niektórych codziennych zadań (takich jak chociażby sprzątanie, robienie zakupów czy opieka nad młodszym rodzeństwem). W trakcie procesu socjalizacji kształtowane są również pewne predyspozycje ułatwiające w przyszłości odgrywanie tych ról. Od pełnosprawnej dziewczynki oczekuje się wręcz, że w przyszłości podejmie i będzie wypełniać podstawowe zadania związane

${ }^{36}$ Małgorzata Wach, Każdy ma..., op. cit., s. 74.

37 Maria Chodkowska, Kobieta niepetnosprawna. Socjopedagogiczne problemy postaw, Lublin 1993, s. 44.

38 Lidia Marszałek, Niepetnosprawność, kobiecość, rodzina..., op. cit., s. 158-176. 
z płcią, takie jak bycie żoną i matką. Dziewczynka z niepełnosprawnością zaś przygotowywana jest głównie do tego, aby była w miarę możliwości samodzielna. Kształtowanie jej tożsamości płciowej, edukacja seksualna i przygotowywanie do pełnienia ról kobiecych poprzez aktywne uczestnictwo zostają $\mathrm{w}$ procesie wychowania pominięte. Warto podkreślić, że pomimo wielu pozytywnych zmian, będących efektem realizowania idei integracji, macierzyństwo i ciąża matek z różnymi niepełnosprawnościami nadal pozostają tematem tabu i wzbudzają szereg skrajnych emocji, nawet wśród personelu medycznego.

O miłości, małżeństwie oraz nadziei na macierzyństwo, które wpływają na postrzeganie kondycji własnego ciała, Angelika Chrapkiewicz-Gądek opowiadała w ten sposób:

Wiesz, Miodziu, za co ja cię tak kocham? Za to, że dla ciebie każdy krok jest taki ważny. Nasza historia zaczęła się trzynaście lat temu. Ksiądz Andrzej Grodecki z Zakopanego zbierał przy parafii grupę osób niepełnosprawnych i tych w pełni sprawnych. Kiedy był u nas w domu po kolędzie, zauważył mój wózek nakryty obrusem (byłam wtedy w sanatorium). Zapytał, kto na nim jeździ, i przekazał mi zaproszenie na spotkanie. Poszłam. Po drugiej stronie, tej sprawnej, był Szymek - przystojny, wysportowany harcerz. Tak go zapamiętałam. Dziś jest strażakiem w Zakopanem, prowadzi szkolenia z ratownictwa. Spotykaliśmy się przez siedem lat. Potem były cztery lata separacji. Ale każde $\mathrm{z}$ nas gdzieś $\mathrm{w}$ głębi serca wiedziało, że jesteśmy dwiema połówkami jednego jabłka. Nie mogliśmy się rozminąć.

We wrześniu ubiegłego roku zabrał mnie na Hel i zaprowadził na plażę. Znalazł to samo miejsce, w którym pierwszy raz się całowaliśmy, i tam mi się oświadczył. [...] Wiedzieliśmy, że weźmiemy ślub w starym kościółku na Pęksowym Brzyzku. W tym samym miejscu, gdzie pobrali się nasi rodzice. [...]. Był tylko jeden problem - wysokie góralskie progi. Kiedy mieliśmy po kilkanaście lat, obiecałam Szymkowi, że pójdę do ołtarza na własnych nogach. Dzień przed ślubem poszłam sobie poćwiczyć. Pierwszy próg jakoś przeszłam, ale drugiego za nic nie byłam w stanie. Usiadłam i zaczęłam płakać. Panie Boże, zrób coś - prosiłam. Kiedy nadszedł dzień ślubu, zobaczyłam Szymka stojącego przy ołtarzu i po prostu do niego poszłam, a właściwie to pobiegłam.

[...] Do pełni szczęścia brakuje mi jeszcze tylko jednej osoby. Będzie miała piękne blond włosy, a na imię Amelka. Jeśli to będzie chłopiec, na pewno coś z Szymkiem wymyślimy. Wierzę, że zdążę zostać matką. Chcę wierzyć39

${ }^{39}$ Małgorzata Wach, Każdy ma..., op. cit., s. 25-27. 
W równie szczęśliwym związku pozostaje autorka innych wspomnień, z niepełnosprawnością spowodowaną wrodzonym zwichnięciem stawu biodrowego i zmianami zwyrodnieniowymi kręgosłupa. Tak opisuje swoje doświadczenia:

Pomimo kołysania się na jedną stronę (lewą) w swoim życiu poznałam wielu chłopców, którzy nie patrzyli na moją utykającą postawę chodzenia. Wybrał mnie jeden i poślubił na dobre i złe. Wyszłam za mąż w 1977 roku za dobrego i wiernego przyjaciela mego życia, który nie patrzy, że jestem kobietą inwalidka, a on zdrowym, ładnym i przystojnym człowiekiem. Nigdy przez 13 lat małżeństwa nie wymówił mi mego inwalidztwa. Zawsze pociesza mnie w chwilach załamania i dniach cierpień. Dorobiliśmy się wspólnie własnego domu $z$ dala od jednych i drugich rodziców. Mamy dwóch synów [...]. Jesteśmy szczęśliwą rodzinąa .

Niepełnosprawność jest poważną próbą dla uczuć partnera, a także sprawdzianem jego dojrzałości psychicznej i społecznej odpowiedzialności. Wielu partnerów autorek omawianych wspomnień wyszło $z$ tej próby zwycięsko. Na szczególny szacunek i uznanie zasługują harmonijne związki dwóch osób z niepełnosprawnościami. Często, pomimo uciążliwości uwarunkowanych stanem zdrowia i niekorzystnej sytuacji ekonomicznej, osoby takie potrafią sprostać wszystkim obowiązkom związanym z podejmowanymi rolami społecznymi. Wymownym przykładem są już same tytuły wspomnień, np.: Matżeństwo chroni nas przed cierpieniem $w$ samotności ${ }^{41}$, Gdyby nie mąż, trafilabym do zakładu opiekuńczego ${ }^{42}$. Jedna $z$ kobiet tak opisuje miłość małżeńską i postawę swojego męża:

Mąż rzeczywiście bardzo mnie kochał. Miałam zawsze problem i do tej pory go mam, iż nigdy i nigdzie nie chce pojechać sam. Ciągle mu muszę towarzyszyć, a ja natomiast wolałabym zostać $\mathrm{w}$ domu, ponieważ zawsze wstydzę się, że kuleję. [...] zaszłam w ciążę. Szaleliśmy z mężem ze szczęścia. Z niecierpliwością czekaliśmy na dziecko ${ }^{43}$.

Wśród analizowanych wspomnień wiele jest opisów rodzinnych dramatów, lekceważenia oraz poniżania, jakiego doświadczały kobiety ze

\footnotetext{
${ }^{40}$ Każde cierpienie ma swój sens, w: Cierpieniem pisane..., op. cit., s. 20.

${ }^{41}$ Małżeństwo chroni nas przed cierpieniem w samotności, w: ibidem, s. 60-62.

${ }^{42}$ Ibidem, s. 63-67.

${ }^{43}$ Ibidem, s. 60-62.
} 
strony swoich mężów, oraz związanego z tym cierpienia. Ilustracją takich przeżyć jest następujący fragment:

Niedługo po ślubie już wiedziałam, jaki on jest. Bardzo często się upijał, a co najgorsze, jak przychodził do domu po kieliszku, to się awanturował i wyciągał ręce do mnie do bicia. Urodziła się córeczka, przyszedł do szpitala, to nawet nie chciał zobaczyć dziecka, tylko mi powiedział, że on odchodzi ode mnie ${ }^{44}$.

Podziw i szacunek budzi macierzyństwo kobiet z niepełnosprawnościami. Olbrzymiej radości z posiadania własnego dziecka zwykle towarzyszyło wiele obaw, dotyczących nie tylko jego stanu zdrowia i przebiegu porodu (o to martwią się wszystkie przyszłe matki), lecz także tego, czy wobec własnych ograniczeń kobiety będą w stanie zaspokoić wszystkie potrzeby dziecka i wychować je na „porządnego człowieka” ${ }^{45}$.

Jak wynika $z$ analizowanych zapisków, wielu kobietom z niepełnosprawnością miłość do dziecka dodawała siły i pozwalała przetrwać najtrudniejsze chwile związane z pogorszeniem się stanu zdrowia, zaostrzeniem się objawów choroby czy opuszczeniem przez męża. Z trudem wychowywane dzieci dojrzewały społecznie szybciej od swoich rówieśników i nierzadko przejmowały obowiązki dorosłych: potrafiły zaopiekować się chorą matką. Były również i takie dzieci, które nie kryły swoich pretensji do matki o to, że nie była w stanie zapewnić im takich warunków, jakie mieli rówieśnicy.

Maria Chodkowska zauważyła, że przeżycia i cierpienia, jakie były udziałem autorek wspomnień, ukształtowały w nich, niezależnie od rodzaju niepełnosprawności, specyficzny typ osobowości. Jego podstawową cechą jest otwartość na potrzeby drugiego człowieka. Możliwość niesienia pomocy innym sprawia tym kobietom olbrzymią radość i daje poczucie własnej wartości ${ }^{46}$.

\section{Aktywność zawodowa, sportowa i społeczna}

Nasze autorki-bohaterki chciały być samodzielne i użyteczne. Nie pozwalały, aby kalectwo uczyniło je ciężarem dla innych, nie korzystały ze zwolnień lekarskich, a konieczność przejścia na rentę i rezygnacji z pracy dla

${ }^{44}$ Najwięcej krzywdy doznałam od męża, w: Cierpieniem pisane..., op. cit., s. 71.

45 Chciałabym wychować dzieci na porządnych ludzi, w: ibidem, s. 83-87.

${ }^{46}$ Maria Chodkowska, Słowo wstępne, w: ibidem, s. 13-14. 
wielu z nich była głębokim dramatem. Życie zawodowe kobiet $z$ niepełnosprawnościami nie jest łatwe. Jednak pomimo ograniczeń odnajdują w sobie siłę i są doskonałymi pracownicami, a niektóre $z$ nich prowadzą własną działalność gospodarczą, aktywizują i motywują inne osoby $\mathrm{w}$ podobnej sytuacji do wzięcia losu w swoje ręce. Ponadto stale podwyższają swoje kwalifikacje zawodowe: zdobywają wykształcenie i biorą udział w różnego rodzaju szkoleniach i stażach. Tego aspektu życia dotyczą następujące fragmenty:

Dostałam pracę w Centrum Turystyki Podwodnej Nautica. Sprzedaję wyprawy nurkowe do Egiptu. Kiedy ktoś zaczyna rozmowę od tego, że ma niepełnosprawność, wypalam: „To świetnie! Nie mogła Pani/nie mógł Pan lepiej trafić”. Najpierw w słuchawce zapada cisza. Potem - jak już wszystko wyjaśnię - śmiech ${ }^{47}$.

Doskonale pamiętam pierwsze dni w pracy. Nie wiadomo było, co ze mną zrobić. „Przecież pani nie ma obu rąk!”. Starałam się uprzedzać ich myśli. Gdy ktoś trzymał w ręce koperty mówiłam: „Daj, zaadresuję i wyślę,. Jak dzwonił telefon, biegłam do słuchawki, by odebrać i pokazać wszystkim, że umiem to zrobić. Potem udowodniłam też, że potrafię obsługiwać komputer i prowadzić samochód ${ }^{48}$.

Istotnym obszarem samorealizacji dla autorek omawianych wspomnień stały się: sport, sztuka i działalność kulturalno-społeczna. Oto przykład wspomnień Katarzyny Rogowiec, która - przypomnijmy - jest mistrzynią świata $\mathrm{w}$ biegach narciarskich i w biathlonie:

Na piątym roku studiów miałam mniej zajęć, więcej wolnego czasu. To właśnie wtedy obudziła się we mnie tęsknota za nartami. Podobno tata założył mi je po raz pierwszy na nogi jakiś czas przed wypadkiem. [...] Pierwszy raz założyłam biegówki na nogi w 2000 roku. Co chwila się przewracałam. Potłukłam sobie wszystko co tylko mogłam. Ale wstawałam, otrzepywałam się, rozglądałam, ile osób to widziało i próbowałam dalej. Wkrótce wzięłam udział w lekkoatletycznych mistrzostwach Polski niepełnosprawnych (pobiegłam tam raczej dla zabawy), w wyścigu na deskorolce $z$ Nowego Targu do Ludźmierza (pierwsze rozbite kolano i podarte spodnie) i pojechałam na zimowe zgrupowanie na nartach biegowych na Turbacz. [...] Po dwóch latach treningów zostałam powołana do kadry narodowej. Zaproponowano mi start na paraolimpiadzie w Salt Lake City ${ }^{49}$.

47 Małgorzata Wach, Każdy ma..., op. cit., s. 24.

${ }^{48}$ Ibidem, s. 75-76.

${ }^{49}$ Ibidem, s. 75. 
Ta niezwykła kobieta była laureatką Konkursu Lady D. im. Krystyny Bochenek w 2008 roku, została odznaczona Krzyżem Kawalerskim Orderu Odrodzenia Polski oraz uznana przez kapitulę Polskiego Komitetu Paraolimpijskiego za najlepszego sportowca 2010 i 2011 roku. Rogowiec jest także członkinią Rady Zawodników przy Międzynarodowym Komitecie Paraolimpijskim i założycielką Fundacji Avanti, która wspiera sportowców z niepełnosprawnością, a przy tym jest żoną i matką dwójki dzieci. Jej historia pokazuje, że dla kobiet dotkniętych niepełnosprawnością wszystko jest możliwe.

Ważnym studium społeczno-psychologicznym i medycznym „okaleczonej kobiecości" jest autobiografia nieżyjącej już Katarzyny Rosickiej-Jaczyńskiej, która chorowała na stwardnienie zanikowe boczne, nieuleczalną, postępującą chorobę neurodegeneracyjną, prowadzącą do całkowitej niepełnosprawności. Była kobietą sukcesu, matką trójki dzieci, modelką i bizneswoman. Choroba rozpoczęła się w najmniej oczekiwanym momencie, kiedy jej firma Ars-media odnosiła spektakularne sukcesy. Oto fragmenty jej wspomnień:

23.07.2000 roku pierwszy raz poczułam dziwne zachwianie równowagi; 21.09.2000 roku pierwszy raz bez powodu upadłam na ulicy; 8.02.2001 roku pierwszy raz poszłam do szpitala; 12.10.2001 roku pierwszy raz szłam o kuli; 2.09.2003 roku pierwszy raz usiadłam na wózku inwalidzkim; 15.05.2002 roku ostatni raz samodzielnie przeszłam przez ulicę; 1.01 .2003 roku ostatni raz prowadziłam samochód; 3.05.2003 roku ostatni raz się kochałam; 29.11.2003 roku ostatni raz rozmawiałam przez telefon; 15.03.2005 roku ostatni raz jadłam samodzielnie i tego dnia utraciłam resztkę wolności ciała i ostatecznie przestałam być niezależna. Stałam się myślącym warzywem, taką myślącą marchewką; może lepiej pietruszką, bo jest bledsza ${ }^{50}$.

[...] znałam siłę swojej kobiecości i bezwzględnie ją wykorzystywałam. Czułam się przede wszystkim kobietą, później właścicielką znanej agencji modelek, a na samym końcu matką trójki dzieci. Byłam samodzielna, niezależna, podziwiana. [...]

Dzisiaj tkwię w bezczasie, bezruchu i bezrobociu. Jestem nieuleczalnie chora. Stopniowo traciłam pracę, pieniądze, urodę, przyjaciół, wreszcie dzieci, aż zaskoczona i przerażona chorobą zamknęłam się w swoim własnym świecie. Zmęczona obojętnością najbliższych przestałam prosić, żeby mnie dostrzegli, a oni zaczęli mnie traktować jak mebel, szafę, której nie da się przesunąć.

${ }^{50}$ Katarzyna Rosicka-Jaczyńska, Ołówek, op. cit., s. 11. 
I tak oto utknęłam w wózku inwalidzkim na środku dywanu w moim pokoju. Dostaję jeść, jestem myta, czesana i... to wszystko. Przekonuję siebie, że nie powinnam narzekać, bo inni mają gorzej. Zawsze może być jeszcze gorzej, tylko... gdzie jest koniec tego gorzej...? ${ }^{51}$

Chociaż choroba zabrała jej wszystko, nie poddała się; mimo bezruchu i milczenia walczyła o własną godność i szukała dla siebie ratunku. Przy pomocy specjalnego programu odczytującego ruchy głowy pisała o tym, jak była szczęśliwa, nienasycona światem, oraz o tym, jak stopniowo choroba przycierała nosa jej pysze i pewności siebie ${ }^{52}$.

$\mathrm{Z}$ analizowanych pamiętników i wspomnień kobiet z niepełnosprawnościami wyłaniają się obrazy osób silnych i wytrwałych w walce o prawo do godnego życia. Tak jak wszystkie inne kobiety autorki pragną kochać i być kochane. Odnajdują się w różnych rolach społecznych i z powodzeniem realizują te przypisane przez kulturę kobiecie. Ich poczucie kompetencji $\mathrm{w}$ tym zakresie jest na tyle wysokie, że częściowa rezygnacja z prezentowania cech określanych społecznie jako kobiece nie narusza ich poczucia bezpieczeństwa i przekonania o własnej wartości. Warto przy tym podkreślić, że możliwość podejmowania i wypełniania przez kobiety $z$ niepełnosprawnościami funkcji społecznych przypisanych kobietom jest fundamentalnym czynnikiem integracji.

Rita Charon zwróciła uwagę na wartość narracji o chorobie w procesie terapeutycznym. Podkreślała, że personel medyczny, słuchając opowieści pacjentów i obserwując ich zachowania pozawerbalne, ma możliwość lepszego zrozumienia ich problemów zdrowotnych, a następnie wykorzystania uzyskanej w ten sposób wiedzy w planowaniu holistycznej opieki odpowiadającej potrzebom pacjenta ${ }^{53}$. Holizm w medycynie, będący otwartym i złożonym rozumieniem istoty ludzkiej, zachęca nas do rozważania aspektów transcendentnych na równi z biologią komórkową. Ignorowanie znaczenia czynników psychologicznych i kulturowych, jak również społecznych i wolicjonalnych, jest jedną z głównych przyczyn obecnego kryzysu medycyny. Biograficzny i społeczny kontekst niepełnosprawności przedstawiany z perspektywy osób dotkniętych tym doświadczeniem ma szczególne znaczenie nie tylko dla przedstawicieli zawodów medycznych: lekarza, pielęgniarki i położnej czy fizjoterapeuty, lecz także dla

${ }^{51}$ Ibidem, s. $5-7$.

${ }^{52}$ Ibidem, s. 295-296.

${ }^{53}$ Patrycja Zurzycka, Teresa Radzik, Medycyna narracyjna..., op. cit., s. 429. 
pracowników socjalnych i tych przedstawicieli innych profesji, w których misję wpisana jest pomoc drugiemu człowiekowi. Narracja niepełnosprawności, podobnie jak zdefiniowana przez Charon narracja choroby, może odgrywać istotną rolę $\mathrm{w}$ kształtowaniu kompetencji społecznych i komunikacyjnych przedstawicieli wymienionych zawodów. Poznawanie historii drugiego człowieka wzmacnia empatię, uczy skupienia, aktywnego słuchania oraz kształtuje zdolność do krytycznego i etycznego rozważania sytuacji pacjenta w szerokim kontekście jego życia. Wyrażone przez pacjenta własne doświadczenia $\mathrm{w}$ połączeniu $\mathrm{z}$ wiedzą profesjonalistów stanowią podstawę diagnostyki zaburzeń i potrzeb pacjenta ${ }^{54}$.

Lektura pamiętników i wspomnień kobiet z niepełnosprawnościami uświadamia nam wszystkim, jak ważna jest akceptacja inności i wsparcie drugiego człowieka. Teksty te uzmysławiają również konieczność zmiany naszego myślenia i działania w takim kierunku, aby stworzyć osobom z niepełnosprawnościami (nie tylko kobietom) warunki rozwoju, kształtowania tożsamości, realizacji zadań i ról społecznych, a w konsekwencji - dokonywania własnych wyborów oraz prowadzenia godnego życia.

Katarzyna Rogowiec zakończyła swoje wspomnienia słowami, które mogą stanowić puentę rozważań przedstawionych w niniejszym artykule:

Ktoś mnie ostatnio spytał, co bym odpowiedziała, gdyby stanęła przede mną wróżka i zapytała, czy chcę odzyskać ręce. Bez wahania odrzekłabym, że tak. Ale pod warunkiem, że mogłabym sobie zostawić wszystko, co do tej pory przeżyłam. W przeciwnym razie ładnie bym podziękowała ${ }^{55}$.

\section{Bibliografia}

Bartuszek A., BeStia ujarzMiona. Moja walka $z$ choroba, Wydawnictwo Trio, Warszawa 2010.

Bollag F., Wyszłam z krainy ciszy. Historia gluchoniemej dziewczyny, która odzyskała stuch, przeł. M. Dutkiewicz, Wydawnictwo Klub dla Ciebie, Warszawa 2007.

Campling J., Better Lives for Disabled Women, Great Britain by Virago, London 1979.

Campling J., Images of Ourselves: Women with Disabilities Talking, Routledge and Kegan Paul, London 1981.

Chodkowska M., Kobieta niepetnosprawna. Socjopedagogiczne problemy postaw, Wydawnictwo Uniwersytetu Marii Curie-Skłodowskiej, Lublin 1993.

54 Ibidem, s. 430.

${ }_{55}$ Małgorzata Wach, Każdy ma..., op. cit., s. 77. 
Cierpieniem pisane. Pamiętniki kobiet niepetnosprawnych, oprac. A. Wieczorek, Wydawnictwo Polskie Forum Chrześcijańsko-Demokratyczne. Rada do Spraw Rodziny Stowarzyszenia PAX, Olsztyn 1991.

Fine M., Asch A., Women with Disabilities: Essays in Psychology, Culture, and Politics, Temple University Press, Philadelphia 1988.

Frey J., W ciemności, przeł. E. Knichnicka, Wydawnictwo Ossolineum, Warszawa 2004. Grandin T., Scariano M., Bytam dzieckiem autystycznym, przeł. E. Zachara, Wydawnictwo Naukowe PWN, Warszawa 1995.

Jakubowska H., Socjologia ciała, Wydawnictwo Naukowe Uniwersytetu im. Adama Mickiewicza, Poznań 2009.

Jaworska M., Syndrom czerwonej hulajnogi, Wydawnictwo Prószyński i S-ka, Warszawa 2013.

Kawczyńska-Butrym Z., Wyzwania rodziny: zdrowie, choroba, niepetnosprawność, starość, Wydawnictwo Pakmed, Lublin 2008.

Keller H., Historia mojego życia, przeł. J. Sujkowska, Wydawnictwo Czytelnik, Warszawa 1978.

Kuszyńska M., Przybyszewska K., Drugie życie, Wydawnictwo Edipresse Polska S.A., Warszawa 2015.

Londsale S., Women and Disability: The Experience of Physical Disability among Women, Macmillan, London-Basingstoke 1990.

Marszałek L., Niepetnosprawność, kobiecość, rodzina, Wydawnictwo Uniwersytetu Kardynała Stefana Wyszyńskiego, Warszawa 2006.

Moje Kilimandżaro. Losy niepetnosprawnych - wspomnienia, Wydawnictwo Fundacja Pomocy Osobom Niepełnosprawnym Filantrop, Poznań 2008.

Mujica B., Frida, przeł. B. Kopeć-Umiastowska, Wydawnictwo Marginesy, Warszawa 2015.

Pasterny H., Moje podróże w ciemno, Wydawnictwo Credo, Katowice 2015.

Pasterny H., Tandem w szkocka kratkę, Wydawnictwo Credo, Katowice 2010.

Picoult J., Krucha jak lód, przeł. M. Juszkiewicz, Wydawnictwo Prószyński i S-ka, Warszawa 2010.

Rosicka-Jaczyńska K., Ołówek, Wydawnictwo Poligraf, Łódź 2011.

Wach M., Każdy ma swoje Kilimandżaro, Wydawnictwo Znak, Kraków 2008.

Wojciechowski F., Niepetnosprawność, rodzina, dorastanie, Wydawnictwo Akademickie „Żak”, Warszawa 2007.

Zurzycka P., Radzik T., Medycyna narracyjna - zarys problematyki, „Problemy Pielęgniarstwa" 2015, 23(3), s. 428-432.

Zychla K., Dziewczynka tańcząca z wiatrem, Wydawnictwo Credo, Katowice 2007. 
A B S T R A C T

\section{„The crippled femininity” - from diaries of disabled women}

A purpose of the thesis is to pay attention to the value of diaries and memoirs of disabled women in understanding the personal and sociocultural complexity of their situation. The objects of the analysis were contents of the memoirs of Polish authors from two last decades and collections of works being outcome of competitions for diaries of disabled persons. Narration included in the analyzed materials of disability, similarly to the narration of illness defined by Rita Charon, is very important for representatives of these professions for which mission to help other people is inherent. Introducing personal experiences of disabled women allows us to identify their health problems and needs, as well as to plan the holistic care, providing such people with worthy and satisfying life.

KEY WORDS: woman, disability, diaries, narrative

\section{A B S T R A K T}

\section{„Okaleczona kobiecość”. Z pamiętników kobiet $\mathrm{z}$ niepełnosprawnościami}

Celem artykułu jest zwrócenie uwagi na wartość, jaką mają pamiętniki i wspomnienia kobiet borykających się z niepełnosprawnością dla osób chcących zrozumieć złożoność ich sytuacji zdrowotnej, osobistej i społeczno-kulturowej. Autorki przybliżyły treść opublikowanych $\mathrm{w}$ dwóch ostatnich dekadach wspomnień Polek, $\mathrm{w}$ tym tekstów wydanych w zbiorach prac będących pokłosiem konkursów na pamiętniki osób $z$ niepełnosprawnościami. Zawarta $w$ analizowanych materiałach narracja niepełnosprawności, podobnie jak zdefiniowana przez Ritę Charon narracja choroby, ma szczególne znaczenie dla przedstawicieli tych profesji, w których misję wpisana jest pomoc drugiemu człowiekowi. Poznanie osobistych doświadczeń kobiet $z$ niepełnosprawnościami pozwala zidentyfikować ich problemy zdrowotne i potrzeby, a także umożliwia zaplanowanie holistycznej opieki, zapewniającej tym osobom godne i satysfakcjonujące życie.

SŁOWA KLUCZOWE: kobieta, niepełnosprawność, pamiętniki, narracja 


\section{MEDYCYNA NARRACYJNA W UJĘCIU METODOLOGICZNYM}


Marta Chojnacka-Kuraś

Uniwersytet Warszawski

\section{Medycyna narracyjna z perspektywy lingwistyki i poetyki kognitywnej}

Narrative medicine to określenie nowej orientacji w medycynie, której podstawowym wyznacznikiem jest indywidualne podejście do pacjenta, nastawione na uważne słuchanie i interpretowanie tego, co mówi on o doświadczeniu choroby. We wprowadzeniu do książki Narrative Medicine: Honoring the Stories of Illness pojęcie narrative medicine definiowane jest jako „wykorzystanie w praktyce medycznej kompetencji narracyjnej, która umożliwia rozpoznanie i zinterpretowanie opowieści o chorobie, a zarazem wchłonięcie ich i pozwolenie, aby nas poruszyły wewnętrznie"1. Nieco bardziej potoczna definicja, przywoływana przez osoby związane $z$ koncepcją narrative medicine, mówi, że jest to „praktyka medyczna, która wie, co zrobić z opowieściami pacjenta" ${ }^{2}$. To sformułowanie pokazuje, że opowiadanie jest jedną z potrzeb pacjentów i stanowi dla nich naturalny sposób komunikowania się z lekarzem (oraz z innymi osobami): pacjenci po prostu opowiadają o sobie i swoim zdrowiu. Problemem jest tylko odpowiednie wykorzystanie tych opowieści do celów klinicznych. Omawiana koncepcja medycyny dostrzega znaczenie takiej formy porozumienia i znajduje dla niej miejsce w strukturze relacji między lekarzem a pacjentem. Twórczynią koncepcji oraz samego terminu narrative medicine jest Rita Charon, profesor Uniwersytetu Columbia w Nowym Jorku, lekarka internistka, ale także literaturoznawczyni, która od dwudziestu

${ }^{1}$ Rita Charon, Narrative Medicine: Honoring the Stories of Illness, New York 2006, s. vii.

${ }^{2}$ Zob. m.in. Małgorzata Nowaczyk, Nasze życie jest opowieścią. Czym jest medycyna narracyjna?, „Medycyna Praktyczna” 2014, s. 125-128. 
lat wykorzystuje narrację w codziennej praktyce zawodowej oraz prowadzi z tego zakresu szkolenia.

W polskich tekstach wyrażenie narrative medicine jest tłumaczone najczęściej jako „medycyna narracyjna”, czasami jako „medycyna narratywna” ${ }^{3}$ W tym artykule będę się posługiwać terminem „medycyna narracyjna”, ponieważ wydaje się on bardziej „zadomowiony” w dotychczasowych publikacjach polskojęzycznych, ukazujących tę problematykę $z$ różnych perspektyw. Wyrażenie „medycyna narracyjna” jest krótkie, co może stanowić zaletę, ale zarazem ze względu na swoją skrótowość nie pokazuje wyraźnie, na czym polega relacja między medycyną a narracją. Bardziej jednoznaczne byłyby określenia $z$ wprowadzonym predykatem, np. „medycyna wykorzystująca narracje pacjentów” lub „medycyna oparta na narracjach", czyli takie, które odpowiadałyby z grubsza opisowemu sformułowaniu w języku angielskim Narrative Evidence-Based Medicine ${ }^{4}$. Przyjmuję jednak, że terminem nazywającym tę koncepcję i funkcjonującym już w polskojęzycznym piśmiennictwie jest „medycyna narracyjna”.

Ogólne założenie medycyny narracyjnej jest takie, że wypowiedzi osób chorych pozwalają im samym uporządkować sytuację, w której się znajdują, a lekarzom (oraz innym osobom sprawującym opiekę medyczną nad pacjentem) umożliwiają poznanie wielu aspektów fizycznej i psychicznej kondycji pacjenta jako indywidualnej jednostki, w atmosferze bliskości i zaufania. Jest to podejście głęboko humanistyczne, stawiające człowieka i jego historię w centrum zainteresowania zespołu medycznego. Postrzeganie choroby jako opowieści, ciągu wydarzeń, historii, nie jest czymś nowym. Taka konceptualizacja widoczna jest nawet na poziomie leksykalnym, np. w polskim wyrażeniu „historia choroby”.

${ }^{3}$ Użycie obu przymiotników, niezależnie od kontekstu medycznego, można różnie oceniać (por. opinię zamieszczoną na stronie Poradni Językowej PWN: https://sjp.pwn.pl/poradnia/haslo/narracyjny-i-narratywny;14920.html). Niektórzy autorzy w prowadzonych przez siebie badaniach wybierają formę „narratywny" (np. analiza narratywna tekstów biblijnych, opis świata narratywnego - por. Daniela Iskrová, Fazy i zasady analizy narratywnej, „Warszawskie Studia Pastoralne” 2013, s. 167-183; analiza narratywna w naukach politycznych - por. Patryk Wawrzyński, Mitomotoryczność opowieści: wykorzystanie analizy narratywnej do badań znaczenia mitów kulturowych (w stosunkach międzynarodowych), „Athenaeum. Polskie Studia Politologiczne" 2012, s. 157-174).

${ }^{4}$ Zob. m.in. Rita Charon, Peter Wyer, Narrative evidence based medicine, „The Lancet" 2008, s. 296-297; https://www.thelancet.com/journals/lancet/article/ PIIS0140-6736(08)60156-7/fulltext [dostęp 14.10.2019]. 
Warto zaznaczyć, że zarówno w tym wyrażeniu, jak i w innych, podobnych, np. „karta choroby”, „karta chorobowa”, uwaga jest skupiona na chorobie, a nie na chorym człowieku. Stanowią one pod tym względem odbicie modelu biotechnologicznego w podejściu do pacjenta. Dla lekarzy praktykujących medycynę narracyjną oczywiste jest, że w tradycyjnej dokumentacji medycznej mieści się zaledwie mały wycinek historii czyjejś choroby, a całościowe doświadczenie chorowania (w wymiarach: społecznym, osobistym, rodzinnym, kulturowym) jest czymś znacznie szerszym i rozgrywa się poza gabinetem lekarskim ${ }^{5}$.

Medycyna narracyjna, jako całościowa, sformalizowana koncepcja kojarzona z ośrodkiem nowojorskim, zyskuje uznanie na świecie. Doceniana jest szczególnie w USA i w krajach Europy Zachodniej, gdzie znajduje podatny grunt ${ }^{6}$. Piśmiennictwo poświęcone tej tematyce stale się rozrasta $^{7}$. W Polsce podejście narracyjne $\mathrm{w}$ medycynie stanowi bardziej ciekawostkę niż narzędzie praktyki klinicznej. Należy jednak zaznaczyć, że coś zaczyna się w tym zakresie zmieniać. W niektórych ośrodkach akademickich, np. w Lublinie, Krakowie czy Warszawie, elementy medycyny narracyjnej w kształcie zaproponowanym przez Charon są przywoływane w ramach kształcenia kompetencji komunikacyjnych studentów medycyny.

Dotychczas powstało kilka polskich publikacji o tej tematyce. Uważam, że warto je w tym miejscu przywołać. Cenny poznawczo jest artykuł

${ }^{5}$ W artykule Małgorzaty Nowaczyk na temat medycyny narracyjnej czytamy: „Coraz częściej lekarze i inni pracownicy medyczni przeczuwają, że historia choroby to o wiele szersza opowieść niż ta zawarta w kartotece pacjenta. Pacjent w szpitalu to zaledwie wprowadzenie do opowieści, dalej jest jej rozwinięcie: jak żyć z chorobą na co dzień. Lekarze najczęściej pozostawiają ten fragment opowieści innym pracownikom medycznym lub pracownikom socjalnym, nie przykładając do niego większej uwagi. Za swój teren uważają gabinet, szpital, przychodnię. W związku $\mathrm{z}$ tym podświadomie nie dostrzegają pacjenta $\mathrm{w}$ całości, $\mathrm{w}$ kontekście życia poza szpitalem" (Nasze życie jest opowieścia...., op. cit., s.126).

${ }^{6}$ Mam tu na myśli takie czynniki, jak: dowartościowanie roli komunikacji $\mathrm{w}$ procesie leczenia, realizowanie $\mathrm{w}$ szpitalach modelu opieki skupionej na pacjencie, opracowanie wystandaryzowanych programów kształcenia kompetencji komunikacyjnych studentów przez cały okres studiów medycznych. Zwolennikiem i propagatorem koncepcji medycyny opartej na narracji jest m.in. Joseph Zarconi, lekarz internista (podobnie jak Rita Charon), profesor Uniwersytetu Medycznego w Ohio.

${ }^{7}$ Por. m.in. Rita Charon, Narrative Medicine..., op. cit.; David Morris, Narrative Medicines: Challenges and Resistance, „The Permanente Journal” 2008, s. 88-96; Rita Charon i in., The Principles and Practice of Narrative Medicine, New York 2017. Każda $z$ tych publikacji dostarcza bogatej literatury przedmiotu, pokazującej źródła i możliwości stosowania medycyny narracyjnej w praktyce. 
Małgorzaty Nowaczyk Nasze życie jest opowieścia. Czym jest medycyna narracyjna? ${ }^{8}$. Polsko-kanadyjska lekarka i pisarka, współpracująca z zespołem nowojorskim, wyjaśnia w tym tekście istotę medycyny narracyjnej z perspektywy lekarza praktyka, omawia trzy podstawowe elementy tej koncepcji (będzie o nich mowa później) i jako ich ilustracje przytacza fragmenty refleksyjnych zapisków, udostępnionych jej przez inną lekarkę, Cindy Donaldson. Autorem kilku prac podejmujących problemy medyczne z perspektywy socjologicznej jest Michał Skrzypek. Właśnie pod tym kątem przedstawia on omawianą tu koncepcję Charon w artykule Medycyna narracyjna jako model zhumanizowanej medycyny $w$ ujęciu socjomedycznym ${ }^{9}$. O medycynie narracyjnej w kontekście postępującej technologizacji medycyny wspomina także w pracy Biotechnologiczna orientacja wspótczesnej medycyny a sposoby doświadczania choroby $i$ relacje lekarz-pacjent ${ }^{10}$. Artykuł Patrycji Zurzyckiej i Teresy Radzik Medycyna narracyjna - zarys problematyki ${ }^{11}$ jest zgodnie z tytułem - ogólnym omówieniem założeń i metod medycyny narracyjnej z perspektywy medycznej, a konkretnie $z$ perspektywy pielęgniarstwa. Autorki zwracają uwagę na możliwości stosowania medycyny narracyjnej w polskiej opiece zdrowotnej, na wynikające z niej korzyści oraz na potencjalne trudności w jej praktykowaniu. O korzyściach, jakie daje medycyna narracyjna (w tym: wyzwolenie empatii u pracowników opieki zdrowotnej, pogłębienie relacji z pacjentem), oraz o jej związku z rozwojem medycyny personalizowanej, wyrażającej się w zindywidualizowanym podejściu do pacjenta, piszą Tomasz Adam Karkowski, Dorota Karkowska i Paweł Skoczylas w tekście Medycyna personalizowana a medycyna narracyjna ${ }^{12}$.

W niniejszym artykule chcę spojrzeć na tematykę medycyny narracyjnej z językoznawczego punktu widzenia. Wyznaczyłam sobie dwa zadania. Po pierwsze, chciałabym przybliżyć czytelnikom podstawy medycyny narracyjnej i pokazać tę koncepcję na tle tego, co o humanistycznych

${ }^{8}$ Małgorzata Nowaczyk, Nasze życie jest opowieścia..., op. cit.

9 Michał Skrzypek, Medycyna narracyjna jako model zhumanizowanej medycyny $\mathrm{w}$ ujęciu socjomedycznym, w: idem (red.), Socjologia medycyny $w$ multidyscyplinarnych badaniach humanizujacych biomedycynę, Lublin 2013, s. 63-83.

${ }^{10}$ Idem, Biotechnologiczna orientacja wspótczesnej medycyny a sposoby doświadczania choroby $i$ relacje lekarz-pacjent, „European Journal of Medical Technologies” 2015, s. 24-32.

11 Patrycja Zurzycka, Teresa Radzik, Medycyna narracyjna - zarys problematyki, „Problemy Pielęgniarstwa” 2015, s. 428-432.

12 Tomasz A. Karkowski, Dorota Karkowska, Paweł Skoczylas, Medycyna personalizowana a medycyna narracyjna, w: Ekonomiczne, medyczne $i$ prawne aspekty zdrowia publicznego, Łódź 2016, s. 85-96. 
aspektach relacji lekarza i pacjenta pisali polscy lekarze humaniści. Po drugie, zamierzam sprawdzić, na ile założenia i cele podejścia narracyjnego $\mathrm{w}$ opiece zdrowotnej są zbieżne z założeniami nurtu kognitywnego w lingwistyce, oraz zastanowić się, czy narzędzia, jakich dostarcza językoznawstwo kognitywne i jakie są wykorzystywane w poetyce kognitywnej, mogą być przydatne w rozwijaniu medycyny narracyjnej w Polsce.

\section{Medycyna narracyjna na tle modelu biopsychologicznego $\mathrm{w}$ medycynie}

W literaturze przedmiotu wymienia się dwa zasadnicze paradygmaty medyczne ${ }^{13}$, nazywane metaforycznie: twardym i miękkim. Twardy paradygmat to podejście biotechnologiczne, w ramach którego zdrowie i choroba są objaśniane terminami biologicznymi, leczenie skoncentrowane jest na chorobie jako zaburzeniu działania organizmu, dominuje ścisła, obiektywna parametryzacja choroby. Miękki paradygmat to biopsychologiczny model zdrowia i choroby (wywodzący się z koncepcji Goerge'a Engela, który w latach 70 . XX wieku dostrzegał potrzebę obecności narracji chorych w praktyce medycznej), podkreślający psychospołeczne i kulturowe uwarunkowania funkcjonowania człowieka w zdrowiu i w chorobie, nastawiony na subiektywne doświadczenie choroby i leczenie nie samej choroby, tylko całego człowieka, wraz z jego otoczeniem.

$\mathrm{Z}$ tego drugiego modelu wyłoniło się wiele koncepcji tzw. medycyny humanistycznej, do których należy także medycyna narracyjna. Michał Skrzypek charakteryzuje te koncepcje jako skoncentrowane na pacjencie i jego relacji z lekarzem, dowartościowujące doświadczenia i narracje chorych w praktyce klinicznej, akcentujące podmiotowość oraz indywidualne charakterystyki chorych (nie tylko psychospołeczne, lecz także genetyczne, na które kładzie nacisk tzw. medycyna personalizowana) ${ }^{14}$.

${ }^{13}$ Zob. m.in. Michał Skrzypek, Biotechnologiczna orientacja wspótczesnej medycyny..., op. cit. $Z$ wymienionymi paradygmatami wiążą się także różne modele komunikacyjne w relacji lekarz-pacjent-rodzina, m.in. model paternalistyczny, partnerski, systemowo-partnerski, charakteryzujące się specyficznymi układami ról, hierarchią i stopniem zaangażowania poszczególnych uczestników procesu leczenia. Zob. Mirosław Jarosz, Zofia Kawczyńska-Butrym, Anna Włoszczak-Szubzda, Modele komunikacyjne relacji lekarz-pacjent-rodzina, „Medycyna Ogólna i Nauki o Zdrowiu” 2012, s. 212-218.

${ }_{14}$ Zob. Michał Skrzypek, Biotechnologiczna orientacja wspótczesnej medycyny..., op. cit., s. 27. 
Tak pojmowana medycyna staje się sztuką, dziedziną humanistyki, nie tylko nauk ścisłych. Jest to niejako powrót do filozoficzno-magicznych źródeł medycyny, opisywanych m.in. w esejach Andrzeja Szczeklika (nawiążę do nich w następnej części), których elementy przetrwały w takich wyrażeniach językowych, jak „sztuka medyczna”, „sztuka lekarska” czy „błąd w sztuce medycznej".

\section{Założenia medycyny narracyjnej a myśl polskich lekarzy humanistów}

Trzy podstawowe komponenty praktyki klinicznej wykorzystującej kompetencję narracyjną w ujęciu Rity Charon to:

1) attention, czyli uwaga, uważne słuchanie i obserwowanie pacjenta (jego zachowania, mimiki, gestykulacji, ułożenia ciała), skupienie się na jego wypowiedzi (na tym, co i jak mówi, jakich używa słów, jak buduje zdania, a także na tym, czego nie mówi, co przemilcza);

2) representation, czyli przedstawienie wniosków z rozmowy z pacjentem (tego, jak lekarz jako słuchacz interpretuje słowa pacjenta i odtwarza we własnej świadomości jego sytuację), w postaci notatki-opowieści o spotkaniu z chorym, dołączonej do dokumentacji medycznej;

3) affiliation, czyli budowanie więzi, relacji opartej na: zrozumieniu (perspektywy pacjenta, jego potrzeb i oczekiwań), wiedzy (zdobytej przez klinicystę podczas rozmowy z chorym) i wzajemnym zaufaniu ${ }^{15}$.

Medycyna narracyjna nie jest odrębną gałęzią nauk medycznych ani praktyką, która ma być stosowana zamiast dotychczasowych metod diagnozowania i leczenia. W koncepcji Charon medycyna oparta na danych uzyskanych z opowieści pacjenta, czyli Narrative Evidence-Based Medicine, ma być uzupełnieniem Evidence-Based Medicine, czyli podejścia wykorzystującego ścisłe, obiektywne dane kliniczne. Według amerykańskiej lekarki uwzględnienie opowieści pacjenta pozwala skuteczniej stosować

${ }^{15}$ Elementy medycyny narracyjnej omawiam przede wszystkim na podstawie prac: Rita Charon Narrative Medicine..., op. cit., oraz Rita Charon i in. The Principles and Practice..., op. cit. Nazwy owych komponentów zachowuję w oryginale; $\mathrm{w}$ znanych mi polskich tekstach dotyczących medycyny narracyjnej stosowane są najczęściej określenia angielskie, choć można też znaleźć takie tłumaczenia, jak: „uwaga”, „uważność”, „uważne słuchanie”, „reprezentacja i relacja”, „budowanie więzi”. 
tę „twardą" wiedzę biomedyczną do leczenia konkretnej osoby, zgodnie z jej potrzebami i oczekiwaniami.

Praktykowanie medycyny narracyjnej wymaga od lekarza określonych umiejętności, nazwanych w literaturze $z$ tego zakresu kompetencją narracyjną (ang. narrative competence). Jej stosowanie wiąże się m.in. ze zmianą metody przeprowadzania wywiadu klinicznego. Chodzi przede wszystkim o wygospodarowanie miejsca na wypowiedź pacjenta (czas, kiedy może on opowiedzieć własnymi słowami o swoim doświadczeniu, o sprawach istotnych $z$ jego punktu widzenia) oraz ukierunkowywanie rozmowy przez lekarza poprzez zadawanie pytań (częściej otwartych niż zamkniętych), dotyczących kwestii poruszanych przez pacjenta. Zobrazuję to przykładem dwóch sposobów prowadzenia rozmowy $z$ pacjentem ${ }^{16}$ :

Lekarz: Od jak dawna ma pani duszności?

Pacjentka: Odkąd rozwiodłam się z mężem.

Lekarz: Kiedy to było?

Rita Charon: Od jak dawna ma pani duszności?

Pacjentka: Odkąd rozwiodłam się z mężem.

Rita Charon: Proszę mi opowiedzieć o pani relacji z mężem.

Podejście narracyjne, zastosowane $\mathrm{w}$ drugim dialogu, daje lekarzowi narzędzie do wydobywania $z$ różnych warstw wypowiedzi pacjenta, $z$ jego narzekań i skarg, ukrytych informacji, które mogą być pomocne w diagnozowaniu i leczeniu. Tak jak w tym przykładzie przyczyną fizycznych dolegliwości pacjentki może być jej relacja $z$ byłym mężem (choroba psychosomatyczna). Zadawanie wyłącznie pytań zamkniętych, dotyczących określonych fizycznych parametrów choroby, może nie naprowadzić na ten trop.

Do takiego rozmawiania z pacjentem trzeba lekarzy przygotować. W trakcie szkoleń na Uniwersytecie Columbia studenci uczą się na materiale literackim i metodami analizy dzieła literackiego rozpoznawać

${ }^{16}$ Przykład, przetłumaczony przeze mnie na język polski i nieco przeredagowany, pochodzi od Anny Hunsaker Hawkins i został przywołany przez Marguerite Holloway w jej artykule When Medicine Meets Literature, opublikowanym w „Scientific American” 1 maja 2005 roku; https://www.scientificamerican.com/article/when-medicinemeets-liter/ [dostęp 15.10.2019]. 
i interpretować m.in. strukturę temporalną tekstu, elementy przestrzeni, strategie narracyjne oraz metafory. Charon sięga po metodę close reading ${ }^{17}$, wywodzącą się z nowej krytyki, zwanej formalizmem amerykańskim. Polega ona - mówiąc ogólnie - na uważnym czytaniu, słowo po słowie, „blisko” tekstu, w ramach jego wewnętrznej struktury, bez uwzględniania kontekstów zewnętrznych, genezy powstania tekstu, wiedzy o autorze itd. Studenci uczą się także wyrażać swoje myśli i odczucia w formie pisemnej, czemu służą ćwiczenia z elementami pisania kreatywnego i refleksyjnego (ang. creative writing i reflective writing) ${ }^{18}$.

David Morris zwraca uwagę na pewną właściwość medycyny narracyjnej, która jest szczególnie istotna z perspektywy lingwistycznej, przyjętej w niniejszym artykule. Podkreśla on mianowicie, że medycyna narracyjna docenia rolę języka w relacji lekarza i pacjenta. Pozwala m.in. rozpoznawać duże schematy narracyjne (np. narrację bezradności, narrację kryzysu), a także dostrzegać wagę pojedynczych słów, które „pacjent przynosi lekarzowi”" ${ }^{19}$. W medycynie narracyjnej, jak pisze Morris, stawia się pytania m.in. o to, jak pacjent „słyszy” słowo „rak”, czy pacjent wróci do lekarza, który powiedział, że odczuwany przez niego ból jest „nieuleczalny"20. Medycyna narracyjna uświadamia także medykom, że pacjent „chwyta się słów lekarza”, zapamiętuje je, powtarza bliskim, analizuje na wszelkie sposoby i czerpie $z$ nich siłę i motywację do leczenia lub wręcz przeciwnie - zawodzi się na nich, słowa stają się przeszkodą w budowaniu relacji. Dlatego tak ważne jest, dodaje Morris, aby lekarz profesjonalnie działał słowami - sprawność językowa lekarza ma być częścią jego klinicznych kompetencji ${ }^{21}$.

Pod kilkoma względami przywołane wyżej stwierdzenia Charon i Morrisa są kontynuacją myśli, które w medycynie już pobrzmiewały. Źródeł omawianego tu podejścia można dopatrywać się choćby w słowach żyjącego na przełomie XIX i XX wieku słynnego kanadyjskiego lekarza Williama Oslera. Jego sentencje na temat lekarza idealnego są powszechnie znane i cytowane. Przytoczę w tym miejscu trzy z nich: „Słuchaj swojego pacjenta; on przekazuje ci diagnozę”, „Dobry lekarz leczy chorobę; wybitny lekarz leczy pacjenta z chorobą” oraz „Zaangażuj pacjentkę w leczenie;

17 Rita Charon i in., The Principles and Practice..., op. cit., s. 180-207.

18 Ibidem, s. 211-232.

19 David Morris, Narrative Medicines..., op. cit., s. 93.

${ }^{20}$ Ibidem.

21 Ibidem, s. 93-94. 
ona nie tylko przekazuje ci diagnozę, lecz także jest integralną częścią wszystkich aspektów swojego zdrowia i opieki medycznej"22.

Również $\mathrm{w}$ polskim piśmiennictwie dotyczącym humanistycznych (w tym językowych) aspektów medycyny tego typu postulaty formułował w latach 70. XX wieku Jan Masłowski. Ten lekarz i filolog (warto odnotować to połączenie dyscyplin), autor pracy Polskie słownictwo lekarskie, zwracał szczególną uwagę na umiejętność cierpliwego słuchania pacjenta oraz na potrzebę posługiwania się przez lekarzy różnymi rejestrami języka. Ta umiejętność pozwala przekładać „spontaniczne opisy dolegliwości", wyrażane przez pacjentów w języku ogólnym, na specjalistyczny język medyczny:

Nie wystarczy dostrzegać tylko chory narząd i wąską skalę badań pomocniczych [...]. Dobry lekarz stara się solidnie zbadać i cierpliwie wysłuchać chorego, zrozumieć jego dolegliwości, trafnie przełożyć w swych myślach to, o czym opowie chory, na język medyczny. [...] opanowanie przez lekarzy bogatego słownictwa nie tylko specjalistycznego, lecz także ogólnonarodowego - w którym amatorsko, spontanicznie opisujemy swe dolegliwości jest $\mathrm{w}$ służbie zdrowia jednym $z$ warunków skuteczności leczenia i sprzyja rozwojowi medycyny ${ }^{23}$.

Idee, które przyświecają medycynie narracyjnej, takie jak dowartościowanie rozmowy i umiejętności słuchania, zwrot ku podmiotowości pacjenta, pojawiają się także w myślach polskiego lekarza o humanistycznej wrażliwości, profesora Andrzeja Szczeklika. W jego eseistycznych wypowiedziach czytamy m.in.:

Zanim lekarz przystąpi do badania, które nazywamy przedmiotowym, czyli do oglądania, obmacywania, opukiwania i osłuchiwania, rozmawia z chorym, słucha jego opowieści, poznaje historię choroby. Pomaga choremu „uwolnić się od zapomnienia”. Takie jest źródło słowa greckiego na określenie prawdy, aletheia. [...] W tym sensie prawda, odsłonięta przez chorego w wywiadzie, wyzwala rozpoznanie, przedstawia je lekarzowi ${ }^{24}$.

${ }^{22}$ Cytaty zaczerpnęłam z artykułu Danny'ego Sandsa Listen to Your Patient; He's Telling You the Diagnosis!; https://thedoctorweighsin.com/listen-to-your-patient-hestelling-you-the-diagnosis/ [dostęp 14.10.2019].

${ }^{23}$ Jan Masłowski, Polskie stownictwo lekarskie, Wrocław 1977, s. 30.

${ }^{24}$ Andrzej Szczeklik, Kore. O chorych, chorobach i poszukiwaniu duszy medycyny, Kraków 2007. 
Chory przychodzi ze swoim bólem, zgryzotą, cierpieniem, trwogą i woła o pomoc. To wołanie, oczywiście, rzadko jest dosłowne. Ma ono różne formy wyrazu. Może to być potok słów, ażeby zażegnać trwogę, albo skamieniałe rysy twarzy, za którymi kryje się nieufność do lekarza. I chory opowiada. Trzeba słuchać, wysłuchać opowieści. Od czasu do czasu pytaniem zapobiec utracie wątku, odsłonić ważki szczegół, uściślić chronologię. Dla opowiadającego - ta historia to rzecz pierwszorzędna. A słuchający niech pamięta, iż jedno $z$ tych opowiadań stanie się jego własnym, któraś z tych chorób dotknie i lekarza ${ }^{25}$.

Zanim lekarz zacznie „postrzegać” [...] słucha opowieści z przeszłości. Umiejętnym słowem pomaga wydobywać na jaw wiedzę, która jest historią, przypomnieniem. Musi być przy tym ciekaw tej historii, tak aby chory czuł, że ktoś, może po raz pierwszy, interesuje się jego biedą. Trzeba, aby mówił $z$ chorym jasnym językiem. Nierzadko rytm mowy, barwa głosu skierują jego uwagę na właściwe rozpoznanie. Zdania wyrzucane szybko, goniące jedno drugie, jakby przynaglane jeszcze przez wilgotne, ruchliwe dłonie, niepokój frazy, a nawet jej wzburzenie każą myśleć o nadczynności tarczycy ${ }^{26}$.

Przywołane słowa krakowskiego lekarza współbrzmią idealnie z założeniami, jakie przyjmuje w swojej koncepcji Rita Charon. Fragmenty, w których jest mowa o słuchaniu opowieści-historii, obserwowaniu pacjenta (jego zachowania, postawy, ruchów ciała) czy o wrażliwości lekarza na drugiego człowieka, odpowiadają pierwszemu i trzeciemu komponentowi medycyny narracyjnej, tj. attention i affiliation. Tym, co w omawianej tu koncepcji stanowi novum w stosunku do myśli polskich lekarzy humanistów, jest element drugi, najbardziej formalny, czyli representation - owa notatka-opowieść przygotowana przez lekarza po spotkaniu z pacjentem i dołączona do dokumentacji medycznej.

Jeśli w medycynie narracyjnej chodzi o zrozumienie wypowiedzi pacjenta, o dotarcie poprzez język do tego, co dzieje się w umyśle człowieka (jak postrzega on swoje chorowanie i siebie w tej sytuacji), i kształtowanie słowami tego, jak ten człowiek myśli o swojej chorobie, to na poziomie ogólnych celów koncepcja ta jest „kognitywna” (czyli, szeroko ujmując, związana z poznaniem) i zbieżna z kognitywnym nurtem współczesnego językoznawstwa. Jeśli dodamy do tego kontekst literacki, wprowadzony przez Charon, to wkraczamy na obszar poetyki kognitywnej i możliwości analitycznych, jakie ona daje.

${ }^{25}$ Andrzej Szczeklik, Katharsis. O uzdrowicielskiej mocy natury i sztuki, Kraków 2009, s. 12.

${ }^{26}$ Ibidem, s. 13. 


\section{Medycyna narracyjna a kognitywne językoznawstwo i poetyka}

Rozpatrując związki medycyny narracyjnej z językoznawstwem kognitywnym ${ }^{27}$, mam na myśli ten nurt współczesnej lingwistyki, powstały w USA w latach 70. XX wieku, a współcześnie rozwijany w wielu ośrodkach naukowych na świecie, którego przedmiotem rozważań jest język ujmowany w relacji z ludzkim umysłem i ludzką percepcją rzeczywistości. Posługiwanie się językiem jest przez kognitywistów traktowane jako jedna ze zdolności poznawczych człowieka: w języku - jak pisze Elżbieta Tabakowska - odbija się proces ludzkiego poznania ${ }^{28}$. Takie podejście, reprezentowane m.in. przez Ronalda Langackera, George'a Lakoffa, Marka Johnsona czy Gilles'a Fauconniera, podkreśla związek działalności językowej człowieka z całością jego psychofizycznego doświadczania świata: bycia w danej społeczności, w kulturze, i bycia jednostką biologiczną ${ }^{29}$. Tabakowska puentuje fragment dotyczący poszukiwania przez kognitywistów „ogólnych zdolności ludzkiego umysłu” słowami:

Staje się zatem rzeczą oczywistą, że w pojęciu kognitywisty język ludzki jako przedmiot badania językoznawcy musi zostać osadzony w szerokim kontekście psychologicznym, socjologicznym i kulturowym. Język człowieka jest obrazem naszego świata, a więc kontekstem, w jakim należy go widzieć, jest świat ${ }^{30}$.

Do charakterystyki językoznawstwa kognitywnego Tabakowska dodaje uwagę, że dla tego nurtu lingwistyki biologia jest modelem bliższym naturze języka niż matematyka czy logika, stawiane za wzór naukowości $\mathrm{w}$ językoznawstwie strukturalistycznym ${ }^{31}$.

Przy ustalaniu podstaw metodologicznych medycyny narracyjnej, wyłożonych w podręczniku The Principles and Practice of Narrative Medicine, Charon i jej współpracownicy bazują przede wszystkim na teorii i filozofii literatury. Narracja jest u nich rozumiana jako opowiadanie (łac. narratio,

${ }^{27}$ Osobom, które chciałyby poznać bliżej okoliczności powstania i najważniejsze założenia tego kierunku we współczesnym językoznawstwie, a także jego relację do innych nurtów lingwistyki, polecam popularnonaukową książkę Elżbiety Tabakowskiej Gramatyka i obrazowanie. Wprowadzenie do jezykoznawstwa kognitywnego, Kraków 1995.

${ }^{28}$ Elżbieta Tabakowska, Gramatyka $i$ obrazowanie..., op. cit., s. 5-7.

${ }^{29}$ Relację między językiem a doświadczeniem widać szczególnie w takich koncepcjach, jak: gramatyka kognitywna Langackera, schematy wyobrażeniowe Lakoffa czy metafora pojęciowa Lakoffa i Johnsona.

${ }^{30}$ Elżbieta Tabakowska, Gramatyka i obrazowanie..., op. cit., s. 13.

${ }^{31}$ Ibidem, s. 12. 
ang. narrative), tworzenie fabuły ${ }^{32}$. Do tez i konkretnych koncepcji lingwistycznych autorzy przywołanej publikacji nawiązują sporadycznie, chociaż są to nawiązania istotne $z$ mojej perspektywy. Za jedną z podstaw filozoficznych koncepcji uznają fenomenologię percepcji, z której wywodzi się pogląd, że mentalność człowieka wynika z jego cielesnego doświadczania świata. Przywołują także ogólną tezę o języku jako uzewnętrznieniu myśli, a ta obecna jest m.in. W relatywistycznej teorii Edwarda Sapira i Benjamina Lee Whorfa oraz w wielu nurtach lingwistyki kognitywnej.

W jednym z rozdziałów przywołanego podręcznika Charon wspomina o wykorzystaniu kognitywnej teorii metafory w badaniach tekstów literackich. Wymienia $\mathrm{w}$ tym miejscu prace czołowych kognitywistów: Lakoffa, Turnera, Fauconniera i Stockwella ${ }^{33}$. We fragmencie dotyczącym metafory jako elementu analizy tekstu metodą close reading Charon docenia osiągnięcia kognitywnej koncepcji metafory i przyznaje, że może ona być przydatna nie tylko w badaniach literaturoznawczych, lecz także w samej medycynie narracyjnej, gdyż pomaga zrozumieć, co ludzie „robią słowami”. Niżej przytaczam cytat, który zdaje się popierać tezę o istnieniu powiązań między medycyną narracyjną i kognitywnym nurtem w lingwistyce i poetyce:

[...] zwrot kognitywny otworzył badania nad metaforą na lingwistyczne i psycholigwistyczne analizy „podstawowych metafor konceptualnych”, które są metaforami konwencjonalnymi („życie to podróż”) i występują w dyskursie mówionym i pisanym wszystkich kultur, w których były poszukiwane. Literaturoznawstwo w ogóle, a medycyna narracyjna w szczególności, mogą się wiele nauczyć z tych nowych koncepcji, aby badać, co ludzie robią słowami [...]. Metafora i inne formy języka figuratywnego są aniołami niezbędnymi do osiągnięcia celów medycyny narracyjnej ${ }^{34}$.

Ze względu na założony w medycynie narracyjnej związek z literaturą, koncepcję tę warto rozważyć pod kątem podobieństwa do poetyki kognitywnej. Zaznaczę w tym miejscu, że dyscyplina ta wykorzystuje $\mathrm{w}$ badaniach nad tekstem literackim instrumenty prymarnie lingwistyczne, m.in. te uwzględnione $\mathrm{w}$ podręczniku do poetyki kognitywnej Petera

${ }^{32}$ Charon odwołuje się do narratologii, przywołuje prace m.in. Rolanda Barthesa, Gérarda Genette'a, Paula Ricoeura.

${ }^{33}$ Rita Charon i in., The Principles and Practice..., op. cit., s. 207.

${ }^{34}$ Ibidem, s. 202. 
Stockwella ${ }^{35}$, czyli: profilowanie, układ figura-tło, kategoryzację, prototypy, schematy wyobrażeniowe, modele poznawcze, przestrzenie mentalne łączone $\mathrm{w}$ tekście oraz metafory. Charon w książce The Principles and Practice of Narrative Medicine nie odnosi się bezpośrednio do poetyki kognitywnej, jednak niektóre jej uwagi, np. te o stosowaniu narracji w pierwszej i trzeciej osobie w opowiadaniu o wizycie pacjentki, można powiązać $z$ aparatem kognitywnym.

Charon uznała mianowicie, że opowiadanie prowadzone w narracji pierwszoosobowej sytuuje ją jako lekarza na innej pozycji niż pacjentkę i powoduje różnicę między ,ja” i „ona” (ang. I i she). Natomiast w narracji prowadzonej w trzeciej osobie dwie kobiety przedstawione zostają na równi: lekarka z pozycji sprawczego agensa przechodzi na pozycję świadka, może obserwować siebie oraz pacjentkę z tej samej perspektywy, a przez to być bliżej niej, lepiej zrozumieć jej sytuację, emocje, odczucia. Sama autorka tak formułuje swoje przemyślenia:

Zdałam sobie sprawę, że pisanie w pierwszej osobie (,ja”) wprowadza różnicę między „ja” a „ona”. Narracja w trzeciej osobie znosi ten formalny podział, pozwala mi przedstawić dwie kobiety w podobny sposób, a jednak niezależnie. Pisanie, zwłaszcza w trzeciej osobie, o tym, co wydarzyło się $\mathrm{w}$ moim gabinecie, przesunęło mnie $z$ pozycji agensa na pozycję świadka. Udało mi się „zobaczyć” moją pacjentkę i siebie z tej samej odległości i pod tym samym kątem, jako dwie różne istoty. Usunięcie się $z$ „narracyjnego fotela kierowcy”, w którym niezmiennie siedzi narrator pierwszoosobowy, dało mi pozycję, z której możliwe jest obserwowanie nas obu osobno, ale $\mathrm{w}$ tym samym świetle ${ }^{36}$.

Widać tu wyraźnie zbieżność z gramatyką kognitywną Langackera, zwłaszcza z jego koncepcją obrazowania sceny, która jest wykorzystywana także $\mathrm{w}$ analizach literackich. To, co dostrzegła Charon, u Langackera jest opisywane jako asymetria między ,podmiotem i przedmiotem procesu konceptualizacji, tj. między konceptualizatorem a tym, co jest konceptualizowane"37. Tłumacząc istotę subiektywnego i obiektywnego konstruowania sceny, Langacker posługuje się analogią do percepcji wzrokowej i pisze tak:

35 Peter Stockwell, Poetyka kognitywna. Wprowadzenie, Kraków 2006.

36 Rita Charon i in., The Principles and Practice..., op. cit., s. 723.

37 Ronald Langacker, Gramatyka kognitywna. Wprowadzenie, przeł. E. Tabakowska i in., Kraków 2009, s. 338. 
W przypadku takiej percepcji postrzegający podmiot jest widzem wyposażonym w odpowiednią aparaturę wzrokową (oczy itp.). Subiektywnym ośrodkiem lokalizacji doświadczenia jest wnętrze głowy (mentalnie skonstruowany punkt perspektywiczny, z którego „wyglądamy” na nasze otoczenie). W każdym danym momencie na pełen zakres świadomej obserwacji składa się wszystko, co mieści się w polu widzenia, zaś obszar pozostający na scenie jest tą częścią tego zakresu, na której w danym momencie skupiona jest uwaga. Przedmiotem percepcji jest zatem to, co skupia na sobie wzrokową uwagę, czyli jest tym przedmiotem pozostającym na scenie, któremu obserwator właśnie się przygląda ${ }^{38}$.

Zastosowanie gramatyki kognitywnej do badań nad językiem artystycznym i przekładem od wielu lat jest przedmiotem myśli i analiz Elżbiety Tabakowskiej $^{39}$. Zdaniem Doroty Korwin-Piotrowskiej prace Tabakowskiej w istotny sposób przyczyniły się do powstania „nowego kognitywnego modelu analizy tekstu", w którym językoznawstwo kognitywne łączy się z poetyką i translatologią ${ }^{40}$.

Między medycyną narracyjną a poetyką kognitywną można dostrzec pewne paralele. W ujęciu Stockwella poetyka kognitywna obejmuje całość schematu „autor-tekst-czytelnik”: pozwala badać interpretację, autorskie spojrzenie na świat i odbiór tekstu przez czytelnika oraz to, jak interpretacja ujawnia się $\mathrm{w}$ tekście ${ }^{41}$. Jeśli przeniesie się to stwierdzenie na grunt medycyny narracyjnej, to można powiedzieć, że obejmuje ona całość relacji „pacjent- wypowiedź/tekst-lekarz” i pozwala na podstawie śladów językowych w wypowiedzi pacjenta badać jego indywidualne spojrzenie na siebie i chorobę oraz możliwości odczytania przez lekarza, zrozumienia i przełożenia na wiedzę medyczną tych komunikowanych przez pacjenta sensów.

Wydaje się, że rozpatrywanie narracji pacjentów od strony językowej, z wykorzystaniem pojęć językoznawstwa kognitywnego, jest równie zasadne, co stosowanie metod analizy literackiej. Mam tu na myśli nie tylko gramatykę kognitywną Langackera, lecz także m.in. semantykę rozumienia i teorię ram interpretacyjnych Charlesa Fillmore'a ${ }^{42}$, która

38 Ibidem, s. 339.

39 Zob. Elżbieta Tabakowska, Językoznawstwo kognitywna..., op. cit.

40 Dorota Korwin-Piotrowska, Powiedzieć świat. Kognitywna analiza tekstów literackich na przykładach, Kraków 2006, s. 12.

41 Peter Stockwell, Poetyka kognitywna..., op. cit., s. 7-8.

42 Zob. Charles Fillmore, Frames and the semantics of understanding, „Querendi di Semantica" 1985, s. 222-255. 
pozwalałaby odtworzyć $z$ wypowiedzi pacjenta zawarty w niej model poznawczy choroby i scenariusz chorowania. Klasyczna koncepcja metafory pojęciowej Lakoffa i Johnsona, doceniona przez Charon, czy teoria przestrzeni mentalnych Fauconniera i Turnera ${ }^{43}$ umożliwiałyby wydobycie sposobów konceptualizowania przez danego pacjenta choroby i swojej relacji z chorobą na różnych jej etapach. $Z$ perspektywy lekarza i powodzenia terapii ważne jest na przykład, czy pacjent ujmuje chorowanie $\mathrm{w}$ kategoriach walki, gry, czy raczej podróży, bycia $\mathrm{w}$ drodze $-\mathrm{z}$ tego mogą wynikać określone konsekwencje: postawa pacjenta wobec leczenia, jego nadzieja, motywacja do leczenia itd. Na takie aspekty wypowiedzi pacjenta i szerzej - komunikacji między lekarzem a pacjentem, która wymaga od tego pierwszego pewnej wrażliwości i plastyczności języka, szczególnie w zakresie doboru metafor, zwracają uwagę m.in. dwaj amerykańscy onkolodzy, Gary Reisfield i George Wilson ${ }^{44}$.

Trudno stwierdzić, która dyscyplina kognitywna może być dla medycyny narracyjnej bardziej inspirująca i przydatna: lingwistyka czy poetyka. Nie sądzę zresztą, aby było zasadne ostre oddzielanie ich od siebie. Wykorzystują podobne instrumentarium, a różnicę między nimi można sprowadzić do skali nagromadzenia i natężenia analizowanych zjawisk w tekstach literackich jest ich więcej niż w wypowiedziach nieliterackich. Przyjmuję tym samym stanowisko Tabakowskiej, która we wstępie do książki Jezzykoznawstwo kognitywne a poetyka przekładu przywołuje i popiera argumentami powszechną jej zdaniem tezę, że:

[...] tradycyjne rozdzielanie linią demarkacyjną domeny językoznawstwa od domeny teorii literatury jest równie sztuczne i niepotrzebne, jak rozgraniczanie „języka” od „sztuki słowa”. W długiej historii obu tych nauk stosunki między językoznawcami i literaturoznawcami przeszły wiele radykalnych przemian. Częste bywały przypadki zapuszczania się na cudze terytorium i równie często ważkie okazywało się wzajemne oddziaływanie obu nauk oraz próby zbliżenia ich do siebie. Uważam, że zastosowanie modelu JK [językoznawstwa kognitywnego - przyp. M.Ch.-K.] w badaniach nad literaturą może sprawić, że próby te będą podejmowane bardziej systematycznie i z większą skutecznością ${ }^{45}$.

${ }^{43}$ Zob. Gilles Fauconnier, Mark Turner, The Way We Think: Conceptual Blending and the Mind's Hidden Complexities, New York 2002.

${ }^{44}$ Gary Reisfield, George Wilson, Use of Metaphor in the Discourse on Cancer, „Journal of Clinical Oncology” 2004, s. 4024-4027.

${ }^{45}$ Elżbieta Tabakowska, Językoznawstwo kognitywne..., op. cit., s. 7-8. 
Według Stockwella różnica między lingwistyką kognitywną a poetyką kognitywną polega na tym, że lingwistyka traktuje tekst literacki jako „kolejny zbiór danych”, a dla poetyki najważniejszy jest kontekst literacki: literackość tekstu, tło historyczne i filozoficzne ${ }^{46}$. W praktyce klinicznej opartej na narracji rozpatruje się z zasady teksty nieliterackie, jakimi są wypowiedzi pacjentów. Literackość w koncepcji medycyny narracyjnej pojawia się na etapie szkolenia, kiedy poprzez kontakt z utworami literackimi rozbudza się wrażliwość studentów na słowo, na wewnętrzną strukturę tekstu itd. W jakimś stopniu pojawia się ona także przy elemencie representation, kiedy lekarz zapisuje (językiem swobodniejszym, niemedycznym, być może też literackim) swoje wrażenia i przemyślenia ze spotkania z pacjentem, współtworząc razem $z$ nim niepowtarzalną opowieść. Ten fakt przemawiałby raczej za podejściem lingwistycznym, ale jest to jedynie hipoteza, którą należałoby zweryfikować w dalszych badaniach.

\section{Perspektywy medycyny narracyjnej}

Można odnieść wrażenie, że medycyna narracyjna jest przykładem docenienia narracji i narracyjności ludzkiego doświadczenia przez kolejną dziedzinę nauki; tę, która $\mathrm{w}$ ostatnich dekadach stała się nadmiernie biotechnologiczna, skupiona na szczegółowych parametrach określających stan organizmu, coraz bardziej oddalona od człowieka jako psychofizycznej całości, jako osoby. Podejście narracyjne w medycynie widziałabym jako przeniesienie na grunt teorii i praktyki medycznej metody, jaką od lat wykorzystuje się (jako narzędzie badawcze) i analizuje narrację (jako kategorię kulturową, antropologiczną, łączoną z tożsamością, trwaniem, ze sposobem pojmowania świata przez człowieka) $\mathrm{W}$ naukach humanistycznych ${ }^{47}$ : psychologii $^{48}$, antropologii ${ }^{49}$, kulturoznawstwie, filozofii, socjologii, literaturoznawstwie $e^{50}$, a ostatnio także

${ }^{46}$ Peter Stockwell, Poetyka kognitywna..., op. cit., s. 8.

47 Jedną z ważniejszych publikacji na temat narracji jako czynnika kształtującego rzeczywistość człowieka jest monografia pod redakcją Jerzego Trzebińskiego, Narracja jako sposób rozumienia świata, Gdańsk 2002.

${ }^{48}$ Zob. m.in. Badania narracyjne $w$ psychologii, Warszawa 2010; Psychologia narracyjna. Tożsamość, dialogowość, pogranicza, Warszawa 2011.

49 Zob. m.in. Hubert Wierciński, Rak. Antropologiczne studium praktyk i narracji, Warszawa 2015.

50 Nurt badań literaturoznawczych nad wielorakimi relacjami łączącymi literaturę i medycynę jest obszerny. Należą do niego m.in. takie monografie, jak: Między 
w językoznawstwie ${ }^{51}$. Ten narracyjny zwrot w badaniach humanistycznych Małgorzata Okupnik puentuje krótko: „Narracja we współczesnej humanistyce jest kategorią fundamentalną"52. Jeśli medycyna ma wrócić do swoich humanistycznych źródeł i stać się ponownie sztuką (a nie nauką ścisłą, którą zresztą nigdy do końca nie będzie), może to zrobić właśnie poprzez dowartościowanie narracji.

Narracyjność - być może często nieuświadomiona - jest obecna w polskiej medycynie, ale raczej w formie mówionej (przejawia się np. w rozmowach lekarzy z pacjentami lub w rozmowach członków zespołu medycznego o pacjentach) niż zapisywanej. David Morris zaznacza, że medycyna narracyjna nie jest dla wszystkich, że jej potencjał jest największy w określonych specjalizacjach medycznych. Można zaryzykować stwierdzenie, że podobnie jest w Polsce: w pewnych obszarach opieki medycznej w procesie diagnozy i terapii w sposób naturalny wykorzystuje się interpretacje opowieści pacjentów. Są to przede wszystkim: opieka paliatywna i hospicyjna, leczenie chorób przewlekłych, onkologicznych, schorzeń neurologicznych (np. chroniczny ból), terapia zaburzeń o podłożu psychicznym. W przypadku np. chorób psychosomatycznych dolegliwości fizyczne nie mają obserwowalnych (gołym okiem lub za pomocą specjalistycznej aparatury), obiektywnie mierzalnych przyczyn - lekarz jest w stanie stwierdzić bądź wykluczyć daną chorobę niemal wyłącznie na podstawie dobrze zebranego wywiadu i właściwie zinterpretowanych słów pacjenta.

literatura a medycyna. Literackie $i$ pozaliterackie dziatania środowisk medycznych a problemy egzystencjalne człowieka w XIX i XX wieku, Lublin 2005; Literatura piękna i medycyna, Kraków 2015; Kobieta, literatura, medycyna, Szczecin 2016. Badacze literatury (tak dawnej, jak i współczesnej) podejmują problematykę choroby i sposobów wyrażania tego doświadczenia (autobiograficzne opowieści o utracie zdrowia, narracje o chorobie, o umieraniu). Obszerne studium patografii (w tym kancerografii), osadzone w kontekście filozoficzno-kulturowym, przedstawia m.in. Małgorzata Okupnik w książce $W$ niewoli ciata. Doświadczenie utraty zdrowia $i$ jego reprezentacje, Kraków 2018. Do tej problematyki odnoszą się także autorki artykułów zamieszczonych w niniejszym tomie: Hanna Serkowska i Monika Ładoń.

${ }^{51}$ Mam tu na myśli szczególnie takie publikacje, jak: Dorota Filar, Narracyjne aspekty językowego świata. Interpretacja marzenia we wspótczesnej polszczyźnie, Lublin 2013; Narracyjność jezyka i kultury. Literatura i media, Lublin 2013 oraz Narracyjność jezyka $i$ kultury, Lublin 2014. Prace zebrane w dwóch tomach tzw. czerwonej serii lubelskiej, $\mathrm{w}$ tym artykuły polskich lingwistów pracujących w aparacie kognitywnym, pokazują wieloaspektową obecność narracji w badaniach filologicznych. Ogrom tego zagadnienia i wielość sposobów jego ujęcia uzmysławia bibliografia każdego $z$ tych tekstów.

${ }^{52}$ Małgorzata Okupnik, $W$ niewoli ciata..., op. cit., s. 143. 
Polskie środowisko medyczne coraz bardziej otwiera się na humanistyczny wymiar tej dziedziny, zaczyna rozumieć kliniczne znaczenie komunikacji z chorym. Wydaje się, że koncepcja medycyny narracyjnej ma potencjał, może znaleźć zwolenników, zwłaszcza jeśli będzie postrzegana (przynajmniej na początku) w kontekście kształcenia i doskonalenia umiejętności komunikacyjnych. Krytyczne uwagi polskich lekarzy oraz studentów medycyny odnośnie do propozycji Rity Charon sprowadzają się do kilku argumentów natury formalno-systemowej (m.in. do tego, że w takiej postaci trudno ją wdrożyć, ponieważ lekarze mają za mało czasu, muszą przyjmować zbyt wielu pacjentów; brakuje miejsca w dokumentacji medycznej; opowiadający zbyt dużo o sobie pacjent może zaburzyć przebieg konsultacji itd. $)^{53}$. Pewne wątpliwości budzą także pojęcia narracyjności i literackości (różnie rozumiane, często utożsamiane z fikcyjnością, zmyśleniem) zestawiane z praktyką kliniczną. Stosunkowo niewiele jest głosów podważających samą idę i potencjalne korzyści wynikające z praktykowania medycyny narracyjnej.

$\mathrm{Z}$ pewnością jest to interesujący obszar badawczy, z konieczności interdyscyplinarny, który otwiera ciekawe perspektywy także dla współczesnej lingwistyki.

\section{Bibliografia}

Badania narracyjne w psychologii, red. M. Straś-Romanowska, B. Bartosz, M. Żurko, Wydawnictwo Eneteia, Warszawa 2010.

Charon R., Narrative Medicine: Honoring the Stories of Illness, Oxford University Press, New York 2006.

Charon R., Wyer P., Narrative evidence based medicine, „The Lancet” 2000, Vol. 371, s. 296-297; https://www.thelancet.com/journals/lancet/article/PIIS01406736(08)60156-7/fulltext [dostęp 14.10.2019].

Charon R., i in., The Principles and Practice of Narrative Medicine, Oxford University Press, New York 2017.

Fauconnier G., Turner M., The Way We Think: Conceptual Blending and the Mind's Hidden Complexities, Basic Books, New York 2002.

Filar D., Narracyjne aspekty jezzykowego świata. Interpretacja marzenia we wspótczesnej polszczyźnie, Wydawnictwo Uniwersytetu Marii Curie-Skłodowskiej, Lublin 2013.

${ }^{53}$ Są to uwagi zgłoszone przez słuchaczy wykładu „Medycyna narracyjna. Wartość opowieści o doświadczeniu choroby w praktyce klinicznej i edukacji”, który wygłosiłam razem z dr Antoniną Doroszewską na Warszawskim Uniwersytecie Medycznym w styczniu 2019 roku. 
Fillmore Ch., Frames and the semantics of understanding, „Querendi di Semantica” 1985, Vol. VI, 2, s. 222-255.

Holloway M., When Medicine Meets Literature, 2005; https://www.scientificamerican. com/article/when-medicine-meets-liter/ [dostęp 15.10.2019].

Iskrová D., Fazy i zasady analizy narratywnej, „Warszawskie Studia Pastoralne” 2013, 18, s. 167-183.

Jarosz M., Kawczyńska-Butrym Z., Włoszczak-Szubzda A., Modele komunikacyjne relacji lekarz- pacjent-rodzina, „Medycyna Ogólna i Nauki o Zdrowiu” 2012, t. 18, nr 3, s. 212-218.

Karkowski T.A., Karkowska D., Skoczylas P., Medycyna personalizowana a medycyna narracyjna, w: A. Jackiewicz, G. Piotrowski, Ł. Sułkowski (red.), Ekonomiczne, medyczne i prawne aspekty zdrowia publicznego, seria "Przedsiębiorczość i Zarządzanie”, t. XVII, z. 12, cz. III, Wydawnictwo Społecznej Akademii Nauk, Łódź 2016, s. 85-96.

Kobieta, literatura, medycyna, red. A. Galant, A. Zawiszewska, Wydawnictwo Naukowe Uniwersytetu Szczecińskiego, Szczecin 2016.

Korwin-Piotrowska D., Powiedzieć świat. Kognitywna analiza tekstów literackich na przykładach, Universitas, Kraków 2006.

Lakoff G., Women, Fire and Dangerous Things: What Categories Reveal about the Mind?, University of Chicago Press, Chicago 1987.

Lakoff G., Johnson M., Metafory w naszym życiu, przeł. T.P. Krzeszowski, Wydawnictwo Aletheia, Warszawa 2010.

Langacker R., Gramatyka kognitywna. Wprowadzenie, przeł. E. Tabakowska i in., Universitas, Kraków 2009.

Literatura piękna i medycyna, red. M. Ganczar, P. Wilczek, Tyniec Wydawnictwo Benedyktynów, Kraków 2015.

Masłowski J., Polskie stownictwo lekarskie, Zakład Narodowy im. Ossolińskich, Wrocław 1977.

Między literatura a medycyna. Literackie i pozaliterackie dziatania środowisk medycznych a problemy egzystencjalne cztowieka w XIX $i$ XX wieku, red. E. Łoch, G. Wallner, Wydawnictwo Uniwersytetu Marii Curie-Skłodowskiej, Lublin 2005.

Morris D., Narrative Medicines: Challenges and Resistance, „The Permanente Journal” 2008, Vol. 12, nr 1, s. 88-96.

Narracja jako sposób rozumienia świata, red. J. Trzebiński, Gdańskie Wydawnictwo Psychologiczne, Gdańsk 2002.

Narracyjność jezzyka i kultury. Literatura i media, red. D. Filar, D. Piekarczyk, Wydawnictwo Uniwersytetu Marii Curie-Skłodowskiej, Lublin 2013.

Narracyjność języka i kultury, red. D. Filar, D. Piekarczyk, Wydawnictwo Uniwersytetu Marii Curie-Skłodowskiej, Lublin 2014.

Nowaczyk Małgorzata, Nasze życie jest opowieścia. Czym jest medycyna narracyjna?, „Medycyna Praktyczna" 2014, 10, s. 125-128 [artykuł dostępny na stronie: www.mp.pl/wena]. 
Okupnik M., W niewoli ciała. Doświadczenie utraty zdrowia i jego reprezentacje, Universitas, Kraków 2018.

Psychologia narracyjna. Tożsamość, dialogowość, pogranicza, red. E. Dryll, A. Cierpka, Wydawnictwo Eneteia, Warszawa 2011.

Reisfield G., Wilson G., Use of Metaphor in the Discourse on Cancer, „Journal of Clinical Oncology" 2004, 22(19), s. 4024-4027.

Sands D., Listen to Your Patient; He's Telling You the Diagnosis!; https://thedoctorweighsin.com/listen-to-your-patient-hes-telling-you-the-diagnosis/ [dostęp 14.10.2019]. Skrzypek M., Biotechnologiczna orientacja wspótczesnej medycyny a sposoby doświadczania choroby i relacje lekarz-pacjent, „European Journal of Medical Technologies” 2015, 1(6), s. 24-32.

Skrzypek M., Medycyna narracyjna jako model zhumanizowanej medycyny w ujęciu socjomedycznym, w: idem (red.), Socjologia medycyny w multidyscyplinarnych badaniach humanizujacych biomedycynę, Wydawnictwo KUL, Lublin 2013, s. 63-83.

Stockwell P., Poetyka kognitywna. Wprowadzenie, przeł. A. Skucińska, red. E. Tabakowska, Universitas, Kraków 2006.

Szczeklik A., Katharsis. O uzdrowicielskiej mocy natury $i$ sztuki, Wydawnictwo Znak, Kraków 2009.

Szczeklik A., Kore. O chorych, chorobach i poszukiwaniu duszy medycyny, Wydawnictwo Znak, Kraków 2007.

Tabakowska E., Gramatyka i obrazowanie. Wprowadzenie do jezykoznawstwa kognitywnego, PAN, Kraków 1995.

Tabakowska E., Jezykoznawstwo kognitywne a poetyka przekładu, przeł. A. Pokojska, Universitas, Kraków 2001.

Wawrzyński P., Mitomotoryczność opowieści: wykorzystanie analizy narratywnej do badań znaczenia mitów kulturowych (w stosunkach międzynarodowych), „Athenaeum. Polskie Studia Politologiczne" 2012, 36, s. 157-174.

Wierciński H., Rak. Antropologiczne studium praktyk i narracji, Wydawnictwa Uniwersytetu Warszawskiego, Warszawa 2015.

Zurzycka P., Radzik T., Medycyna narracyjna - zarys problematyki, „Problemy Pielęgniarstwa" 2015, 23(3), s. 428-432.

\section{A B S T R A C T}

\section{Narrative medicine from the perspective of cognitive linguistics and poetics}

The article presents the principles and methods of narrative medicine (the approach in medicine propagated by Rita Charon from the Columbia University) from the perspective of selected fields in cognitive linguistics (including the Ronald 
Langacker's model of cognitive grammar and the conceptual metaphor theory by George Lakoff and Mark Johnson) and cognitive poetics (according to Elżbieta Tabakowska and Peter Stockwell). The contexts of the considerations are biopsychological paradigm of medicine and some publications of Polish doctors (Jan Masłowski and Andrzej Szczeklik) who touch upon the humanistic aspects of medicine (such as the role of language in the doctor-patient communication and the ability to listen attentively to the patient), so crucial in the Charon's concept of narrative medicine.

KEY WORDS: cognitive linguistics, cognitive poetics, narrative medicine

\section{A B S T R A K T}

\section{Medycyna narracyjna z perspektywy lingwistyki i poetyki kognitywnej}

Artykuł przedstawia podstawowe założenia medycyny narracyjnej w ujęciu Rity Charon $z$ Uniwersytetu Columbia oraz stosowane $\mathrm{w}$ tym podejściu metody pod kątem zbieżności z wybranymi nurtami językoznawstwa kognitywnego (m.in. $z$ modelem gramatyki kognitywnej Ronalda Langackera i teorią metafory pojęciowej George'a Lakoffa i Marka Johnsona) oraz poetyki kognitywnej (w ujęciach Elżbiety Tabakowskiej i Petera Stockwella). Kontekstem rozważań nad medycyną narracyjną są ogólnie scharakteryzowany biopsychologiczny paradygmat medycyny oraz publikacje polskich lekarzy (Jana Masłowskiego i Andrzeja Szczeklika), którzy poruszają humanistyczne aspekty medycyny (w tym rolę języka i umiejętności uważnego słuchania $\mathrm{w}$ relacji $\mathrm{z}$ pacjentem), tak istotne $\mathrm{w}$ koncepcji Charon.

SŁOWA KLUCZOWE: językoznawstwo kognitywne, poetyka kognitywna, medycyna narracyjna 
Hanna Serkowska

Uniwersytet Warszawski

\section{Żaden pacjent nie jest wyspą lub czego lekarze mogą nauczyć się $\mathrm{w}$ kontaktach $\mathrm{z}$ pacjentami}

Zawarte w niniejszym artykule refleksje po pierwsze mają mnogie źródła inspiracji. Związane są one bezpośrednio ze stosunkowo nową dyscypliną - medycyną narracyjną, której pomysłodawczynią jest Amerykanka Rita Charon ${ }^{1}$. Po wtóre, wynikają ze zmiany paradygmatu obowiązującego w opiece medycznej od blisko dekady ${ }^{2}$, polegającej na odejściu od paternalizmu, samodzielnego i arbitralnego decydowania przez posiadającego wiedzę eksperta, lekarza, o tym, czy i jak leczyć. Obecnie podejście to zastępuje się różnymi modelami autonomii (partnerskim, konsumenckim), które zakładają możliwość podejmowania decyzji wspólnie z pacjentem. Zmianę tę wymusiła $\mathrm{w}$ znacznym stopniu prawnie usankcjonowana konieczność podejmowania przez przedstawicieli opieki medycznej

${ }^{1}$ Choć Brian Hurwitz i Trisha Greenhalgh z King's College w Londynie jako pierwsi (1999) opisali korzyści z wprowadzenia medycyny narracyjnej do programu nauczania, narracyjne podejście do opieki klinicznej ujęła $\mathrm{w}$ definicyjne ramy Rita Charon: Narrative Medicine: Honoring the Stories of Illness, New York 2006.

${ }^{2}$ Zob. pracę Beaty Antoszewskiej, Ku człowiekowi. Doświadczanie relacji z pacjentem $w$ narracjach lekarzy. Wybrane zagadnienia pedagogiki leczniczej, Kraków 2018. Zgromadzona tu wiedza na temat relacji lekarz-pacjent jest wynikiem badań prowadzonych na gruncie medycyny, psychologii zdrowia i socjologii medycyny. Równocześnie powstaje mnóstwo prac naukowych i popularyzatorskich poświęconych psychologii relacji z pacjentem, rozmowie, komunikacji, porozumieniu. Publikuje się podręczniki mające doskonalić komunikację z pacjentem przez idealizowanie słowa, które leczy i nadaje sens chorobie, zapewnia poszanowanie godności chorego, czasem obrazujące, jak frazeologia stosowana przez przedstawicieli zawodu uwłacza chorym. 
działań zmierzających do uzyskania ważnej zgody pacjenta ${ }^{3}$. Dla niniejszego tekstu ważniejszy od uwarunkowań wspomnianych zmian jest jednak fakt, że obserwowany ostatnio awans chorego czy pacjenta do rangi podmiotu procesu terapeutycznego i medycznego (ang. empowered person), do poziomu partnera przedstawiciela zawodu medycznego w tym sensie, że wraz z nim przyjmuje za ów proces odpowiedzialność, dał być może asumpt do powstania wielu spośród interesujących nas lekarskich narracji, „równoległych historii choroby”. Po trzecie, szerszym kontekstem, w jakim zrodził się pomysł niniejszego artykułu, są ustalenia tzw. nowej humanistyki, które przedstawię niżej.

Być może więc to za sprawą wspomnianej zmiany paradygmatu lekarze często sięgają po pióro i opisują swoje doświadczenie pracy w zawodzie. Czasem wybierają formę beletryzowanego dziennika. Nie szczędzą przy tym cierpkich słów organizacji (i niedofinansowaniu) systemu ochrony zdrowia, skarżą się na przeciążenie pracą stażystów, zarabiających mniej niż szpitalny parkometr. Zwracają także uwagę na nieprawidłowe relacje międzyludzkie. W analizowanym przeze mnie materiale - a składają się nań wypowiedzi lekarzy o ich relacji z pacjentami - brakuje tekstów takich, jak Będzie bolało Adama Kaya ${ }^{4}$, będących w zamierzeniu krytyką systemu (brytyjskiego) opieki zdrowotnej i bez niuansów, w sposób miejscami niewyszukany dających wyraz rozczarowaniu warunkami pracy. Na analizowany zbiór tekstów składa się zapoczątkowany 15 czerwca 2017 roku blisko stuodcinkowy cykl Die ene patiënt („Jeden pacjent”), ukazujący się w magazynie „Sir Edmund”, weekendowym dodatku do dziennika

${ }^{3} \mathrm{~W}$ kwestii bioetyki oraz regulacji prawnych dotyczących ochrony zdrowia zwłaszcza w przedmiocie ważności zgody pacjenta na działanie diagnostyczne i medyczne (pacjent musi być odpowiednio poinformowany, w pełni kompetentny i podejmować decyzję dobrowolnie) - odsyłam do podręczników: Bernard Gert, Charles M. Culver, K. Danner Clouser, Bioetyka. Ujęcie systematyczne, Gdańsk 2009, i rodzimych tomów Kazimierza Szewczyka, Bioetyka. 1, Medycyna na granicach życia i Bioetyka. 2, Pacjent $w$ systemie opieki zdrowotnej, Warszawa 2006 i 2009. O etyce relacji między profesjonalistą a jego klientem, w tym przypadku pacjentem, pisze też Paweł Łuków w: idem, Granice zgody: autonomia zasad $i$ dobro pacjenta, Warszawa 2005.

${ }^{4}$ W 2018 r. krakowska oficyna Insignis wydała przekład aż dwóch głośnych lekarskich relacji: Będzie bolato Adama Kaya i Niewyjaśnione okoliczności Richarda Shepherda. Teksty te, oscylujące na granicy ekshibicjonizmu i obsceniczności, pokazują, jak długą drogę przebyły narracje lekarzy, choćby od czasu równie głośnej powieści Jürgena Thorwalda, Pacjenci, Kraków 1973. Thorwald zabiegał w niej o rozwój transplantologii, przekonywał do przeszczepów, walczył z uprzedzeniami, powołując się także na relacje pacjentów, którzy przyczynili się do postępu transplantologii. 
„De Volkskrant”" . Jest to szczególny zbiór tekstów. Akcent pada w nich na specyfikę tego wymagającego zawodu oraz na relacje jego przedstawicieli z pacjentami. Lekarze różnych specjalności opowiadają tu o jednym pacjencie, który odmienił ich podejście do wykonywanej pracy, a w niektórych przypadkach odcisnął głębokie piętno na całym ich życiu. Jest to rodzaj osobistego świadectwa, w którym wyciszone zostały inne aspekty pracy lekarza (takie, jak: obowiązek realizowania procedur ministerialnych i wewnątrzszpitalnych, dbałość o akredytację placówki, przeciążenie biurokracją itd.), dający wgląd wyłącznie $w$ to, jak relacja $z$ pacjentem ewoluuje w miarę rosnącej samoświadomości lekarza, oraz jak istotne jest kształcenie wszechstronnych kompetencji, w tym zdolności komunikacyjnych $^{6}$, umożliwiających także zdanie relacji z doświadczeń, czasem niezwykle dla lekarza trudnych.

Podobnie rozkłada też akcenty Rita Charon w ósmym rozdziale swojej książki Narrative Medicine: Honoring the Stories of Illness, zatytułowanym The Parallel Chart („Równoległa karta pacjenta/historia choroby”). Autorka opisuje praktykę notowania doświadczenia relacji z pacjentem i wyjaśnia, jakimi narzędziami posługuje się $\mathrm{w}$ dydaktyce. Jej eksperyment polega na tym, że poza wpisami w karcie pacjenta rezydenci mają coś o nim napisać, posługując się codziennym, zwykłym językiem . Mają zanotować -

${ }^{5}$ Wybrane teksty są dostępne na stronie https://www.volkskrant.nl/kijkverder/2017/dieenepatient/ [dostęp 8.01.2019]. Wiosną 2019 roku Ellen de Visser wydała wybrane wywiady w publikacji pt. Die ene patiënt. Zorgverleners over de patiënt die hun leven voor altijd veranderde (Ambo Anthos, Amsterdam 2019).

${ }^{6} \mathrm{O}$ tym, że właściwa komunikacja z pacjentem oddziałuje nie tylko na proces leczenia, lecz także zapobiega wypaleniu zawodowemu u przedstawicieli zawodów medycznych, a szerzej u osób niosących pomoc innym, przekonują zwolennicy Grup Balinta (zob. np. B.W. Wasilewski, L. Engel, Balint group training: theory and application, Warszawa 2015). Michael Balint zapoczątkował w latach 50. XX wieku badania relacji między lekarzem a pacjentem, skupiając się na tym, jak wzajemnie uwarunkowane są los pacjenta i praca lekarza. Ignorowanie przez osobę pomagającą tego, co przeżywa pacjent (lęk, niepewność, złość, smutek, bezradność, a także wynikających z działania mechanizmów obronnych niezgody, oporu uruchomionych w sytuacji zależności), powoduje pogorszenie stanu chorego, a zarazem pogorszenie samopoczucia lekarza. Metoda Balintowska zaleca unikanie selekcji, de facto cenzury uczuć, zezwalającej na uczucia pozytywne, a wypierającej negatywne, co może powodować rozwój schorzeń psychosomatycznych, prowadzących do syndromu wypalenia zawodowego zwiększającego śmiertelność wśród specjalistów.

${ }^{7}$ Rita Charon - lekarka i literaturoznawczyni - podkreśla, że umocowanie do zajmowania się medycyną narracyjną, do kształcenia u studentów medycyny zdolności posługiwania się zwyczajnym, niemedycznym językiem, wynika z jej 
chodzi o pisanie refleksyjne (ang. reflective writing) - jak podchodzą do doświadczającego choroby i jak ich podejście wpływa na opiekę nad pacjentem. Narracja „ma za zadanie kształcić wewnętrzne życie lekarzy” W celu „doskonalenia metod rozpoznawania, czego doświadcza pacjent i jego rodzina $\mathrm{w}$ związku z choroba, a także, niestety, $\mathrm{z}$ powodu tego, jak odnoszą się do nich lekarze"9. Fakt, że adepci nauk medycznych mają napisać „coś" o swoim pacjencie, uczy ich „bycia uważnymi słuchaczami” ${ }^{10}$, pacjenci bowiem nie przynoszą ze sobą do gabinetu gotowych koherentnych historii. Mówią, opowiadaja, czasem nieskładnie, nieporadnie, w sposób pozbawiony logiki. Medycyna narracyjna uczy uważnego słuchania, dalej reprezentacji, czyli przedstawienia historii pacjenta sobie i innym; a w konsekwencji prowadzi do afiliacji, tj. wzajemnego zrozumienia. Pisząc o pacjentach, medycy piszą więc też o sobie. Wśród zamieszczonych w książce transkrypcji przeprowadzonych zajęć znajdziemy pięć równoległych historii choroby. Rezydenci/studenci odczytują sporządzoną kartę na głos. Wtedy Charon prosi pozostałych uczestników zajęć o reakcję. Zadaje pytania pomocnicze: „Co widzisz, co słyszysz, czego więcej chciałbyś się dowiedzieć?". Okazuje się wtedy, że nie tylko każdy słuchacz widzi i słyszy co innego - cóż za ważna nauka: dowiedzieć się, że nie istnieje jedna jedyna właściwa lektura, a każda sprzeczna interpretacja wzbogaca prawdę tekstu - lecz także każdego w wysłuchanej historii ciekawi zupełnie co innego ${ }^{11}$.

Dodatkowym impulsem do zajęcia się równoległymi historiami choroby są dla mnie zwłaszcza dwie odmiany nowej humanistyki: humanistyka zaangażowana i humanistyka kognitywna. Obie sugerują pewien metodologiczny profil, a zarazem ideologiczne ramy dla badania postaw charakterystycznych dla autorów tekstów z cyklu „Jeden pacjent”. Sam korpus poświadcza potrzebę na nowo pojmowanego zaangażowania dyscypliny, postrzegającej zaangażowanie jako formę interwencji w świecie

zawodowego przygotowania i wykształcenia (,gwarantuję, że jestem lekarzem z przygotowaniem literaturoznawczym" - pisze Rita Charon, Narrative Medicine..., op. cit., s. 155).

8 Ibidem, s. 155.

9 Ibidem.

10 Ibidem.

11 Analizowane równoległe karty pacjenta czytam jako teksty kulturowe (nie tak, jak przedmioty naturalne, które są obiektami nauk ścisłych i przyrodniczych), będące obiektami semiotycznie zorganizowanymi i znaczącymi. 
utrwalonych postaw i poglądów, krytycyzm wobec założeń neutralności i autonomii ${ }^{12}$. Co więcej, idzie o partycypacyjną postawę podmiotu zapisującego i analizującego równoległe karty pacjenta ${ }^{13}$ - w nowej humanistyce w miejsce murów między dyscyplinami kładzie się mosty umożliwiające współpracę i wymianę myśli z przyrodoznawstwem i naukami ścisłymi. Postawą typową dla „nowego humanisty” - staje się nim w równym stopniu autor równoległych kart pacjenta, co analizujący je podmiot - jest wreszcie kreowanie krytycznej nadziei, pielęgnowanie nakazu „utopii wyobrażonej”, tworzenie „realistycznych mikroutopii” jako fundamentu lepszych modeli współbycia i wspólnotowości ${ }^{14}$ nie tylko w odniesieniu do uprawianych dyscyplin, lecz także we własnym środowisku.

Zwłaszcza ten ostatni aspekt pomaga przeciwdziałać epistemicznej asymetrii generującej wykluczenie, pojęcie często we współczesnej humanistyce omawiane. Termin „epistemiczna (nie)sprawiedliwość”, wprowadzony w 2007 roku w odniesieniu do mniejszości (wyznaczanych przez rasę, płeć, wiek, status społeczny) przez Mirandę Fricker ${ }^{15}$, Havi Carel wykorzystała do opisu zjawisk obserwowanych w systemie opieki zdrowotnej, zwłaszcza w podejściu lekarza do pacjenta ${ }^{16}$.

12 Ryszard Nycz, Nowa humanistyka w Polsce: kilka bardzo subiektywnych obserwacji, koniektur, refutacji, „Teksty Drugie” 2017, s. 26.

${ }^{13}$ O tym, jednym z podstawowych wyznaczników makrodziedziny nowej humanistyki - tj. o poznaniu od wewnątrz, uczestniczącym, performatywnym - pisze też Kirsten Hastrup: „nie możemy w żaden sposób dotrzeć do rzeczywistości, jeśli nie staniemy się jej częścią” (Social anthropology. Towards a pragmatic enlightment, „Social Anthropology" 2005, cyt. za: Ewa Klekot, Rozpoznawanie topografii, w: M. Buchowski, A. Bentkowski (red.), Kolokwia antropologiczne: problemy wspótczesnej antropologii społecznej, Poznań 2014, s. 76.

14 Ewa Domańska, Sprawiedliwość epistemiczna w humanistyce zaangażowanej, „Teskty Drugie” 2017, s. 45.

15 Miranda Fricker (Epistemic Injustice: Power and the Ethics of Knowing, Oxford 2007, s. 1) wyróżnia dwa rodzaje niesprawiedliwości (inspirując się oczywiście fundamentalną pracą Alasdaira MacIntyre'a Czyja sprawiedliwość? Jaka racjonalność?): niesprawiedliwość świadczenia - kiedy uprzedzenia słuchającego wpływają na postrzeganie poziomu wiarygodności mówiącego, oraz niesprawiedliwość hermeneutyczną (np. policja nie wierzy osobie, ponieważ jest czarna) - mającą miejsce wcześniej, tj. kiedy luka w zbiorowej bazie interpretacji stawia mówiącego w niekorzystnej sytuacji w kontekście nadawania sensu doświadczeniom społecznym (np. ktoś cierpi z powodu molestowania seksualnego czy mobbingu w kulturze, która nie rozwinęła krytycznego podejścia do tego pojęcia).

16 Chory może być traktowany jako osoba kognitywnie niewiarygodna, emocjonalnie zdyskredytowana, egzystencjalnie niestabilna czy inaczej niesprawna, przez 
Z pozbawionym wiarygodności i wiedzy chorym, opowiadającym rzeczy rzekomo nieistotne lub absurdalne, należy ograniczyć kontakt do informacji „gdzie boli” i potwierdzenia tożsamości. Podejście takie - nawiązujące do starego paternalistycznego modelu relacji lekarza i pacjenta odbiera pacjentowi rolę „agensa wkładczego” (ang. contributing agent) i poddaje go espistemicznemu wykluczeniu (ang. epistemic exclusion) ${ }^{17}$. Aby temu przeciwdziałać, Carel proponuje fenomenologiczny zestaw narzędzi (ang. toolkit), za pomocą którego wytwarza się hermeneutyczny kontekst, $\mathrm{w}$ jakim pacjenci mogliby dzielić się swoim doświadczeniem choroby z pracownikami służby zdrowia. Korzystający z tych narzędzi pacjenci będą potrafili lepiej artykułować doświadczenie choroby, dzięki czemu staną się bardziej efektywnymi uczestnikami opieki zdrowotnej. Przedstawiciele zawodów medycznych zaś będą dzięki temu w stanie lepiej zrozumieć, jak pacjent doświadcza choroby, poprawią swoje umiejętności słuchania i rozumienia.

Podobne zasady i mechanizmy można zaobserwować w cyklu „Jeden pacjent", w którym dwa bieguny relacji - zagrożone, narażone lekarskie „ja” i pozbawiony adekwatnej wiedzy i umiejętności komunikacyjnych pacjent - zostają ukazane w wyraźnym wzajemnym sprzężeniu. Tak samo jak w równoległych historiach choroby Rity Charon mamy tu do czynienia $z$ wypowiedziami o ściśle ograniczonym formacie (jedna strona), napisanymi prostym językiem, wolnym od specjalistycznych terminów. Psychologię trzecioosobową zastępuje pierwszoosobowa, introspekcyjna lekarz obserwuje także siebie i opowiada w pierwszej osobie. Perspektywa zatem pozostaje niezmiennie ta sama - lekarska. Przedmiotem wypowiedzi jest pacjent i jakieś szczególnie ważne zdarzenie, którego sprawujący opiekę medyczną doświadczył pod wpływem kontaktu z chorym. Opisywane sytuacje bywają skomplikowane pod względem medycznym i egzystencjalnym. Inaczej jednak niż u Charon (jej zdaniem równoległa karta pacjenta to nie osobisty dziennik, nie list do brata, lecz przedmiot w nauce zawodu „w służbie pacjentowi” ${ }^{18}$ ) relacje lekarzy zebrane w holenderskim

co jego świadectwo i interpretacja stają się podejrzane, wyłącznie z uwagi na jego status jako chorego. Zob. Havi Carel, Phenomenology of Illness, Oxford 2016, s. 184.

${ }^{17}$ Havi Carel bada przypadki, kiedy pacjentowi przypisywana jest zaniżona lub zawyżona wiarygodność. Lekarz może błędnie rozpoznać chorobę, postawić błędną diagnozę na skutek błędnej oceny poziomu wiarygodności pacjenta (ang. mis-assigning credibility to the patient - ibidem, s. 182).

${ }^{18}$ Rita Charon, Narrative Medicine..., op. cit., s. 157. 
cyklu "Jeden pacjent” są historiami obarczonymi dużym ładunkiem emocjonalnym i mają bardzo osobisty charakter. Pod względem rodzaju wypowiedzi analizowane teksty są hybrydyczne, lokują się na pograniczu wywiadu i konfesji, wyznania i spowiedzi. Zdecydowana większość analizowanych tekstów powstała po upływie dwudziestu lub więcej lat od opisywanego zdarzenia. Piszący znajdują się najczęściej u kresu kariery i, co znamienne, nie posługują się fikcyjnymi imionami. Teksty są podpisane imieniem i nazwiskiem, opatrzone specjalnością lekarza i nazwą placówki, w której pracuje. Udział w omawianym cyklu stanowi dla autorów okazję, by po raz pierwszy w ciągu wieloletniej praktyki - nikt z nich nie przeszedł kursu medycyny narracyjnej - opisać swój kontakt z pacjentem. Ten zaś, postawiony $\mathrm{w}$ centrum uwagi, zostaje uwolniony od klątwy wykluczenia. Chory zostaje zauważony i uważnie wysłuchany przez lekarza. Staje się obecny, co zmienia układ sił opisywany wcześniej jako epistemiczna asymetria, której istnieniu trudno przecież zaprzeczyć w relacji lekarzpacjent, a której sama refleksja i wynikająca $z$ niej narracja skutecznie przeciwdziałają. Teksty te, jak się przekonujemy, dają świadectwo tworzenia lokalnych (realistycznych) mikroutopii - zdolnych przekształcić społeczne relacje, oparte na więzi wiedzy i władzy łączącej zdrowego i chorego, sprawującego opiekę i pacjenta, silnego i słabego, w modele relacji oparte na współbyciu. Dlatego można by sugerować włączenie medycyny narracyjnej do zestawu dyscyplin nowohumanistycznych proponowanego przez Ryszarda Nycza ${ }^{19}$.

Moja analiza zawartości kart pacjenta doprowadziła do wyodrębnienia typów wypowiedzi. Wspólne wszystkim jest jednak nastawienie na słuchanie. Primum audire zatem, bo umiejętność i potrzeba słuchania pacjenta są nie do przecenienia. Ben Crul (65 lat; „De Volkskrant”, 12.08.2017), lekarz pierwszego kontaktu w Lejdzie, pisze: „Znaczenia, jakie ma rozmowa $z$ pacjentem dla pacjenta, nie trzeba nikomu tłumaczyć, ale jakie ta rozmowa ma znaczenie dla lekarza - owszem" ${ }^{20}$. Dzięki pacjentowi zrozumiał on, że w szpitalu czuł się nie na swoim miejscu, wolał pracować jako lekarz rodzinny. Wspomina lekarza, który odwiedzał przed laty jego chorą, przedwcześnie zmarłą matkę. Niczego nie można już było dla niej zrobić, on jednak przychodził, zdejmował marynarkę, siadał na

${ }^{19}$ Ryszard Nycz, Nowa humanistyka w Polsce..., op. cit.

${ }^{20} \mathrm{O}$ znaczeniu rozmowy pisał Hans-Georg Gadamer: „rozmowa podtrzymuje humanistyczną relację między tymi, którzy są tu fundamentalnie nierówni: między lekarzem a pacjentem" (O skrytości zdrowia, przeł. A. Przyłebski, Poznań 2011, s. 138). 
krawędzi łóżka i był przy niej. Słuchał jej i okazywał zainteresowanie. W wydaniu z 1.06.2018 roku czytamy kartę Wilco Achterberga, specjalisty geriatry (54 lata), który opisał przypadek przebywającego od siedmiu lat W domu opieki seniora: drażliwego, ciągle wadzącego się z personelem i uskarżającego się na chroniczny ból. Od kiedy Achterberg zaczął z nim rozmawiać, a zwłaszcza uważnie go słuchać, samopoczucie i zachowanie pensjonariusza znacząco się poprawiły. Korzyści z lepszej komunikacji są jeszcze dalej idące: geriatra wyciąga $z$ tego zdarzenia ważną naukę - błąd, który najczęściej popełniamy w opiece nad starszymi pacjentami, polega na tym, że chcemy szybko znaleźć rozwiązanie problemu medycznego, podczas gdy ważniejszy jest poświęcony choremu czas, czas spędzony na słuchaniu. Po pierwsze słuchać. Doświadczenie zapisane w równoległej historii choroby przez chirurga naczyniowego Marca Scheltingę (lat 58) dowodzi wreszcie, że aktywne słuchanie i rozmowa z pacjentem niosą korzyści dla całego systemu opieki zdrowotnej. Można oszczędzić czas i pieniądze, na przykład nie wykonywać zbędnych badań. Wystarczy porozmawiać z chorym, który sam dużo na swój temat powie. Trzeba umieć słuchać („De Volkskrant”, 2.09.2017) ${ }^{21}$.

Największa grupa tekstów opowiada o tym, jak zmienił się sam lekarz, jego podejście do zawodu i pacjenta, wreszcie praktyka diagnostyki i terapii. Czytamy w nich o potrzebie budowania zaufania, a nawet o poczuciu humoru. Niektórzy lekarze, choć to zdecydowana mniejszość, chwalą się dobrym uczynkiem (np. jak znaleźli miejsce w domu opieki dla bezdomnego starca $z$ objawami demencji, jak z poświęceniem opiekowali się samotnym pacjentem). Historie te pokazują, jak przemożna chęć podjęcia działania biomedycznego, typowa dla medycyny evidence based zostaje skorygowana przez uświadomione lekarzowi w trakcie rozmowy z pacjentami i ich bliskimi ograniczenia i różnorakie pozabiomedyczne uwarunkowania. Czasem chodzi o bezsilność medycyny bądź samego lekarza, jak pisze lekarz domowy pracujący w dzielnicy imigrantów, Sandra Bijl („De Volkskrant”, 21.10.2017). Czasem stawką jest pokora wobec nieprzewidywalności życia i zdrowia, niezależnie od podjętych medycznych działań i oczekiwań („De Volkskrant”, 11.08.2018). Kiedy indziej okazuje się,

${ }^{21}$ Formułowanym tu dezyderatom nie sprzyja fakt, że żyjemy w czasach automatyzacji i robotyzacji medycyny, zwłaszcza zabiegowej. A może w dobie sztucznej inteligencji właśnie indywidualny kontakt z pacjentem, komunikacja i narracja, jako część kompetencji lekarskich, których pożytki dopiero lepiej poznajemy, zdołają ocalić zawód lekarza. 
że rodzice mających się narodzić dzieci mogą nie podejmować decyzji, które są dla nich najkorzystniejsze, np. czy ratować życie dziecka, które będzie wymagało stałej opieki lub urodzi się upośledzone (pisze o tym neonatolog Hans van Goudoever, „De Volkskrant”, 29.06.2017). Kiedy indziej lekarz może błędnie oceniać sytuację, jeśli opiera się jedynie na naukowych badaniach i wiedzy klinicysty. Jednak ocena ta może zyskać na trafności, kiedy zostaje uzupełniona o niepotwierdzone badaniami obserwacje, jak twierdzi Idie Pijnenburg („De Volkskrant”, 10.02.2018). Z takich obserwacji wynika na przykład, że śpiew może pomóc pacjentom słyszącym głosy, bo w czasie śpiewu aktywna jest prawa półkula mózgu, podobnie jak w przypadku słyszanych głosów (pisze psychiatra Iris Sommer, „De Volkskrant”, 22.07.2017), że aktywność fizyczna w trakcie chemioterapii może nawet o rok wydłużyć życie pacjenta z przerzutami (notuje Pieter van den Berg, „De Volkskrant”, 11.11.2017) i korzystnie wpływa na gojenie po operacji plastycznej poparzonej twarzy (o czym wspomina Paul van Zuijlen, „De Volkskrant", 16.03.2018). Dowiadujemy się także, że powtórzenie badań może przynieść wielkie korzyści, zwłaszcza wtedy, gdy nie wiadomo, co choremu dolega (pisze Jaap Karsten, „De Volkskrant”, 20.01.2018).

Do innej grupy można zaliczyć historie o pożytkach wynikających z zaprzestania uporczywego leczenia i sztucznego utrzymywania pacjenta przy życiu, a także o tym, że przeciwieństwem terapeutycznego zacietrzewienia nie są bezradność ani bierność, lecz towarzyszenie choremu. Wyborem mniejszego zła może też być zgoda na przeprowadzenie aborcji, na przykład kiedy społeczne problemy ciężarnej są niewyobrażalnie wielkie, jak u czternastoletniej dziewczyny, która zostawiła noworodka na mrozie („De Volkskrant”, 6.04.2018). Czasami niepodejmowanie żadnych działań jest najlepszym rozwiązaniem. Neurochirurg opisuje wrażenie, jakie zrobiła na nim spokojna i zdecydowana reakcja rodziców na diagnozę: złośliwy, nieuleczalny rak mózgu u sześcioletniej córki. Wobec braku nadziei na dalsze życie, wspólnie postanowili dalej jej nie dręczyć, zaprzestać daremnej terapii. Dziewczynka żyła jeszcze siedem miesięcy (Pieter van Eijsden, „De Volkskrant”, 15.07.2017). Kiedy w grę wchodzi możliwość powstrzymania się od wszelkich działań, trzeba nauczyć się o tym rozmawiać z pacjentem. Zwłaszcza dziś, kiedy medycyna stała się dziedziną wyczynową ${ }^{22}$, nastawioną na sukces, a lekarze mówią przede

${ }^{22} \mathrm{~W}$ zebranym materiale nie brakuje też historii opowiadających o lekarzu podejmującym wielkie wyzwania zwieńczone sukcesem. Wszystko za sprawą decyzji 
wszystkim - zresztą wielu pacjentów tego właśnie od nich oczekuje o możliwej terapii, trzeba uczyć się rozmawiać z pacjentami, pytać, czego jeszcze oczekują od życia. Trzeba ich najpierw lepiej poznać. Niektórzy pacjenci opuszczający gabinet bez wypisanej recepty czują na przykład, że lekarz nie dość poważnie podszedł do ich przypadku. Tymczasem, o czym pisze Marco Blanker, lekarze pierwszego kontaktu często mają do czynienia z pacjentami, którzy nie są chorzy, tylko na coś się uskarżają („De Volkskrant”, 15.09.2018). Nastawieni na działanie, na ustawiczną walkę z chorobą lekarze nie potrafią mówić o tym, że można nie podejmować żadnych działań i jest to dla nich samych bardzo trudna decyzja.

Do wyjątkowej grupy należą te równoległe karty pacjenta, w których lekarz przyznaje się do błędu. Mówi wprost: jestem winny, nie zbadałem dość dobrze, zbagatelizowałem, nie zleciłem dalszych badań, nie wezwałem chirurga, popełniłem błąd nie do naprawienia (to wyznania Everta den Drijvera, 67 lat, „De Volkskrant”, 2.12.2017 i Petera de Leeuwa, 69 lat, „De Volkskrant”, 2.02.2018). Czasem jest to przyznanie się do pomyłki, polegającej na przyjęciu zbyt wąskiej perspektywy ${ }^{23}$, podporządkowanej pragnieniu wyleczenia schorzeń wcześniej stwierdzonych, przez co niezauważona pozostała choroba rozwijająca się później (pisze o tym gastroenterolog Joos Drenth, 54 lata, „De Volkskrant”, 14.07.2018). Kiedy piszący przyznaje się do słabości, lęku, depresji, traumy związanych z cierpieniem lub śmiercią pacjenta, powołuje się niejednokrotnie na stawiane przedstawicielom zawodów medycznych rozmaite dodatkowe wymagania: zachowania tajemnicy zawodowej, właściwego dystansu do chorego, przestrzegania granic

pacjentki, jak ta, u której ginekolog-onkolog, Frédéric Amant stwierdził raka macicy i która postanowiła („z wdzięczności”, ponieważ dzięki badaniu płodu dowiedziała się o chorobie) poddać się chemioterapii, żeby uratować dziecko. Dostępna literatura zalecała w podobnych przypadkach operację, podawała szanse zdrowia dziecka, nic nie mówiła o szansach matki. Dzięki tej pacjentce, która sama przeżyła i urodziła zdrowe dziecko, Amant i jego zespół rozpoczęli międzynarodowe badania, zebrali dostatecznie dużo danych potwierdzających zasadność procedury, której poddawane są dziś setki innych ciężarnych z chorobą onkologiczną („De Volkskrant”, 4.08.2018).

${ }^{23}$ Czasem lekarz pokonuje własną niechęć. Tak stało się $z$ anestezjologiem Robem Slappendelem, niechętnym decyzji o ratowaniu życia (rzekomej) niedoszłej samobójczyni po tym, jak okazało się, że kobietę z okna wypchnął jej mąż („De Volkskrant”, 13.10.2018). Podobnie chirurg Arnold van de Laar uporał się ze swoimi uprzedzeniami po rozmowie z pacjentką, która opowiedziała mu, jak po przebytej operacji zmieniło się jej życie. Wykonuje teraz zabiegi resekcji żołądka u osób $z$ otyłością, nie zastanawiając się, czy musi operować kogoś, kogo nie rozumie („De Volkskrant", 8.12.2018). 
i zachowania równowagi między zaangażowaniem a powstrzymaniem się od działania. Wskazana jest też znajomość obowiązujących w społeczeństwie zasad, jak piszą medyk pracujący w Ugandzie dla organizacji Lekarze bez Granic Jaap Karsten („De Volkskrant”, 20.01.2018) i lekarz domowy muzułmańskich imigrantów w Hadze Sjoerd Zwart („De Volkskrant”, 25.05.2018). Do sfery lękliwie skrywanej należy cierpienie lekarza, który odchodzi z pracy po samobójczej śmierci pacjenta. O osamotnieniu, poczuciu porażki i wstydzie kolegi pisze Floris Bijlma („De Volkskrant”, 27.04.2018). Wreszcie wyjątkowe muszą wydać się też nieliczne przypadki, kiedy lekarze przyznają się do cierpienia i lęku, których sami doświadczają. Identyfikują się wtedy $z$ chorym nie na prawach utopii zrealizowanej, lecz na zasadzie wspólnoty doświadczeń, gdy sami zapadają na ciężką chorobę i stają się pacjentami.

Można zapytać, czy po to, żeby w pełni rozumieć chorego, lekarz powinien sam doświadczyć choroby? Czy rację miał Platon, twierdząc, że lekarz powinien sam przejść choroby, które chce leczyć2 ${ }^{2}$ ? Czy tylko wtedy możliwa jest prawdziwa komunikacja? Tak twierdzi Emil Cioran, przekonany, że bez bólu nie ma świadomości: „czyż możemy wyobrazić sobie cierpienie, które nie byłoby «naszym» cierpieniem?”"25. Nie o taką przeto fenomenologię choroby nam chodzi ${ }^{26}$. W dwu przypadkach opisanych pod

24 Platona cytuję za Michelem de Montaigne'em, który pisze: „Platon słusznie powiadał, iż kto by chciał być prawdziwym lekarzem, winien sam przejść wszystkie choroby, które chce leczyć, i wszystkie wypadki i okoliczności, o jakich chce sądzić” (Próby, przeł. T. Żeleński Boy, ks. III, s. 293).

${ }_{25}$ O człowieku zdrowym Emil Cioran (idem, O chorobie, przeł. I. Kania, Kraków 1994) pisze: „Nie mając nic do przekazania, neutralny aż do utraty tożsamości, tonie w swoim zdrowiu - nic nie znaczącym stanie doskonałości, szczelnego zamknięcia na śmierć i w ogóle wszystko, braku uwagi dla siebie i świata. Dopóki w nim tkwi, jest jak przedmiot; gdy go zeń wyrwać, otwiera się na wszystko i zaczyna wszystko rozumieć. Oto wszechwiedza trwogi” (s. 63) i „Cierpieć to być całkowicie sobą, to osiągnąć stan niezbieżności ze światem" (s. 69).

${ }^{26}$ Nie zależy nam przecież na wskazywaniu winnego, wytykaniu błędów - któż ich nie popełnia? - ani na demotywującej krytyce, jaką można znaleźć w książce pod tytułem W szoku. Moja droga od lekarki do pacjentki. Cała prawda o stużbie zdrowia?, Kraków 2018, napisanej przez pracującą na oddziale intensywnej terapii lekarkę Ranę Awdish. Dopiero wtedy, gdy sama została pacjentką, odkryła ona lekarską znieczulicę, bo tak teraz z perspektywy pacjenta ocenia zachowanie swoich kolegów. Brak empatii, liczne zaniedbania: ponad połowa tej książki tworzy „kliencką skargę” na opiekujący się nią personel - tak wypowiada się o niej inny (były) lekarz, znany nam już jako autor Będzie bolało, Adam Kay w recenzji zamieszczonej na łamach 
szyldem Zelf ziek, czyli „Sam chory”, czytamy, że dopiero doświadczenie choroby uzmysłowiło lekarzowi, jak dotkliwa dla chorego jest przepaść między lekarzem a pacjentem. Warner Prevoo, radiolog interwencyjny („De Volkskrant”, 10.11.2018) notuje:

W pokoju opisu wyników badań razem z kolegą obejrzałem moje płuca, pojawiające się we fragmentach na obrazach tomografu. Jako lekarz oceniałem, opisywałem setki, tysiące takich obrazów. Pisałem, co widziałem. W lewym płucu dostrzegłem dużą plamę, po prawej stronie czarne kropki. Kolega radiolog natychmiast zaczął mnie inaczej traktować. Jak pacjenta.

Hester Oldenburg, chirurg onkolog, specjalistka od raka piersi, pisze („De Volkskrant”, 6.01.2018):

Dziwnie się czułam, kiedy rano pojechałam do siebie do pracy jako pacjentka. Najtrudniejsze było to, że tak wiele o wszystkim wiedziałam. Wiedziałam, że po naświetlaniach nie było szansy na operację oszczędzającą pierś.

Zwłaszcza te ostatnie równoległe historie choroby pokazują, jak pożądane jest dążenie do przeciwdziałania epistemicznej niesprawiedliwości i wykluczeniu. A praktyki wypracowane na płaszczyźnie medycyny narracyjnej - praktyki przekształcające relację lekarz-pacjent i zmieniające lekarza $z$ biernego adresata historii chorego w aktywnego słuchacza czynią z niej jakże pożądaną dyscyplinę nowej humanistyki ${ }^{27}$, nastawioną na sprawczość, a zarazem znoszącą bariery i podziały, aktywnie zaangażowaną, budującą wspólnotę. W centrum uwagi stawiającą człowieka, osobę pacjenta i lekarza.

„The Guardian” (https://www.theguardian.com/books/2018/jan/28/in-shock-rana-awdish-review-doctor-turns-patient; data dostępu 17.10.2010). O niższym statusie chorego lekarza, o tym, jak dotkliwie młody neurochirurg odczuł odwrócenie perspektyw i zamianę ról, kiedy usłyszał diagnozę (zaawansowany rak płuc) pisze też Paul Kalanithi w Jeszcze jeden oddech, Kraków 2016.

${ }^{27}$ Powołuję się tu na Julię Kristevę (J. Kristeva, J. Venier, (Bez)sens stabości. Dialog wiary $z$ niewiarą o wykluczeniu, Poznań 2012), która w 2011 roku w Asyżu przedstawiła Dziesięć zasad dla humanizmu XXI wieku, kreśląc nowe ścieżki humanizmu (świeckiego i chrześcijańskiego), bo ten stary próbował ze wszech miar nie dostrzegać kruchości człowieka. Trzeba starać się zmieniać nasze podejście do słabości, wszak jesteśmy istotami cielesnymi, organicznymi, słabymi. Upominając się o namysł nad chorym w kulturze przymusu dobrego samopoczucia, dążymy do zniesienia bariery dzielącej chorych i zdrowych. 
W tym duchu - i to już ostatnia prezentowana równoległa historia choroby - kardiolog Angela Maas opowiada o owym ,jednym pacjencie”, który sprawił, że w swojej praktyce lekarskiej nauczyła się „wybierać właściwą drogę". Z modelu arbitralnej reżyserii lekarza specjalisty przeszła do wspólnego $z$ pacjentem ${ }^{28}$ podejmowania decyzji (chora $z$ poważnym odkształceniem zastawki serca odmawiała leczenia, nie zgadzała się na wykonanie żadnego zabiegu). Pacjent bowiem, notuje Maas, nie jest własnością lekarza, należy do samego siebie („De Volkskrant”, 21.07.2018).

\section{Bibliografia}

Antoszewska B., Ku człowiekowi. Doświadczanie relacji z pacjentem $w$ narracjach lekarzy. Wybrane zagadnienia pedagogiki leczniczej, Oficyna Wydawnicza Impuls, Kraków 2018. Awdish R., W szoku. Moja droga od lekarki do pacjentki. Cała prawda o stużbie zdrowia, przeł. R. Śmietana, Wydawnictwo Znak, Kraków 2018.

Barański J., Steciwko A., Relacja lekarz-pacjent. Zrozumienie $i$ wspótpraca, Elsevier Urban \& Partner, Wrocław 2013.

Carel H., Phenomenology of Illness, Oxford University Press, Oxford 2016.

Charon R., Narrative Medicine: Honoring the Stories of Illness, Oxford University Press, New York 2006.

Cioran E., O chorobie w: idem, przeł. I. Kania, Oficyna Literacka, Kraków 1994.

„De Volkskrant”; https://www.volkskrant.nl/kijkverder/2017/dieenepatient/ [dostęp 13.10.2019].

Domańska E., Sprawiedliwość epistemiczna w humanistyce zaangażowanej, „Teksty Drugie” 2017, nr 1, s. 41-59.

Ehrenheich B., Natural Causes, Granta, London 2018.

Fricker M., Epistemic Injustice: Power and the Ethics of Knowing, Oxford University Press, Oxford 2007.

${ }^{28} \mathrm{Na}$ ujemnym biegunie modeli zakładających autonomię pacjenta autorzy równoległych kart pacjenta lokują też sytuacje, w których chory, przekonany o całkowitej niezależności, samodzielnie podejmuje niebezpieczne dla własnego zdrowia decyzje. Taką pacjentką wydaje się być Barbara Ehrenheich, która w książce Natural Causes (London 2018) sprzeciwia się zarówno nadmiernej jej zdaniem skłonności do diagnozowania, przesadnej wierze chorych w możliwości wyleczenia, jak i nieograniczonej władzy białych kitli nad ciałem pacjenta. Odpowiedzią na sceptycyzm Amerykanki niech będzie karta Riema Vermeulena („De Volkskrant”, 1.09.2018), stwierdzającego, że zadaniem lekarza jest dopomóc choremu odnaleźć właściwą drogę, co jest niemożliwe bez dobrej komunikacji i wzajemnego zaufania. Zob. także Jarosław Barański i Andrzej Steciwko, Relacja lekarz-pacjent. Zrozumienie i wspótpraca, Wrocław 2013. 
Gadamer H.G., O skrytości zdrowia, przeł. A. Przyłebski, Media Rodzina, Poznań 2011.

Gert B., Culver Ch.M., Clouser D.K., Bioetyka. Ujęcie systematyczne, przeł. M. Chojnacki, słowo/obraz terytoria, Gdańsk 2009.

Hastrup K., Social anthropology. Towards a pragmatic enlightenment, „Social Anthropology” 2005, 13(2), s. 133-149.

Kalanithi P., Jeszcze jeden oddech, przeł. Ł. Małecki, Wydawnictwo Literackie, Kraków 2016.

Kay A., Będzie bolało, przeł. K. Dudzik, Insignis, Kraków 2018.

Klekot E., Rozpoznawanie topografii, w: M. Buchowski, A. Bentkowski (red.), Kolokwia antropologiczne. Problemy wspótczesnej antropologii spotecznej, Wydawnictwo Nauka i Innowacje, Poznań 2014, s. 76.

Kristeva J., Venier J., (Bez)sens stabości. Dialog wiary z niewiara o wykluczeniu, przeł. K. Wierzchosławski, P. Wierzchosławski, W drodze, Poznań 2012.

Łuków P., Granice zgody: autonomia zasad $i$ dobro pacjenta, Wydawnictwo Naukowe Scholar, Warszawa 2005.

Montaigne M. de, Próby, ks. 3, przeł. T. Żeleński Boy, PIW, Warszawa 1957.

MacIntyre A., Czyja sprawiedliwość? Jaka racjonalnośc?, przekł. pr. zbior., red. A. Chmielewski, WAIP, Warszawa 2007.

Nycz R., Nowa humanistyka $w$ Polsce: kilka bardzo subiektywnych obserwacji, koniektur, refutacji, „Teksty Drugie” 2017, nr 1, s. 18-40.

Shepherd R., Niewyjaśnione okoliczności, przeł. U. Gardner, Insignis, Kraków 2018.

Szewczyk K., Bioetyka. 1, Medycyna na granicach życia, Wydawnictwo Naukowe PWN, Warszawa 2006.

Szewczyk K., Bioetyka. 2, Pacjent w systemie opieki zdrowotnej, Wydawnictwo Naukowe PWN, Warszawa 2009.

Thorwald J., Pacjenci, przeł. M. Oziembłowski, Wydawnictwo Literackie, Kraków 1973. Visser de E., Die ene patiënt. Zorgverleners over de patiënt die hun leven voor altijd veranderde, Ambo Anthos, Amsterdam 2019.

Wasilewski B.W., Engel L. (red.), Balint group training: theory and application, Eneteia IPS Publications, Warszawa 2015.

\section{A B S T R A C T}

\section{No patient is an island or what medical doctors can learn from patients}

The article analyses doctors' accounts of the experiences with patients that have changed their professional outlook. The stories of these doctors, representing different specializations, are modeled on Rita Charon's "parallel charts", and collected in the Dutch cycle of "That one patient". This article attributes the emergence of 
a growing number of medical doctors who report on their profession and their relations with the patients to the fact that a new autonomy and participation-based model has replaced the traditional paternalistic model of medicine. The author further advocates the inclusion of narrative medicine as one of the disciplines of the new humanities. Next to the need to replace disease-focused medicine by patient-centered medicine, which emerges from the analyzed texts is a clear evidence of countless benefits - including benefits for the doctor - following from adjusting one's language to the language of the patient, promoting the ability to listen, understand and communicate with the patient.

KEY WORDS: narrative, medical doctor, patient, medicine, epistemic exclusion

\section{A B S T R A K T}

\section{Żaden pacjent nie jest wyspą lub czego lekarze mogą nauczyć się $\mathrm{w}$ kontaktach $\mathrm{z}$ pacjentami}

Autorka artykułu proponuje analizę wypowiedzi lekarzy różnych specjalności, zawartych w holenderskim cyklu „Jeden pacjent”, a wzorowanych na „równoległych historiach choroby/kartach pacjenta" Rity Charon. Wiąże pojawianie się rosnącej liczby relacji lekarskich dotyczących wykonywanego zawodu i kontaktów z pacjentem z zastąpieniem modelu paternalistycznego autonomiczno-partycypacyjnym i postuluje uwzględnienie medycyny narracyjnej jako jednej $z$ dyscyplin nowej humanistyki. $Z$ badanych tekstów wyłania się zarówno potrzeba zastąpienia medycyny skupionej na chorobie medycyną ześrodkowaną na osobie pacjenta, jak i korzyści - w tym dla lekarza - płynące $z$ dostosowania do języka pacjenta, ze zdolności słuchania, rozumienia i poznania chorego.

SŁOWA KLUCZOWE: narracja, lekarz, pacjent, medycyna, epistemiczne wykluczenie 


\section{Aleksandra Szugajew}

Uniwersytet Warszawski

\section{Metoda uważnego czytania (close reading) $\mathrm{w}$ medycynie narracyjnej}

Literaturę, jak zauważa Anne Hudson Jones, łączą z medycyną „silne więzi, wywodzące się jeszcze ze starożytnych czasów; setki dzieł literackich poświęcono takim czy innym szeroko pojętym zagadnieniom natury medycznej, jak choroba, cierpienie i śmierć" ${ }^{1}$. Choć medycyna, podobnie jak inne nauki ścisłe, bywa postrzegana jako dziedzina oparta na faktach, nakierowana na postęp i w dużym stopniu opierająca się na rozwiązaniach technologicznych, prowadzących do doskonalenia opieki zdrowotnej, ma ona także i inny, bardziej humanistyczny wymiar. W medycynie mamy do czynienia $z$ inherentnym dualizmem, bo choć do uprawiania jej konieczna jest rozległa wiedza, dostęp do wielu danych i obiektywizm, to ostatecznie sprowadza się ona do kontaktu dwóch osób: lekarza i pacjenta. Dochodzi wtedy do spotkania dwóch światów: świata specjalisty i świata człowieka chorego.

Właśnie ze względu na specyfikę tego spotkania pojawiają się opinie, że $\mathrm{w}$ programie studiów medycznych powinny się znaleźć przedmioty z zakresu literaturoznawstwa. Poprzez dogłębną analizę wybranych dzieł literackich można uwrażliwiać (bądź podtrzymywać wrażliwość) studentów medycyny na doświadczenie i perspektywę chorego oraz pokazać im, jak ważna $w$ relacji z pacjentem jest empatia. Nietrudno wyobrazić sobie stereotypowego studenta medycyny, który spędził mnóstwo czasu na drobiazgowej analizie szczegółów funkcjonowania ludzkiego organizmu, a nie jest $\mathrm{w}$ stanie nawiązać porozumienia $\mathrm{z}$ siedzącym przed nim człowiekiem. Spotkanie z pacjentem jest niekiedy sytuacją emocjonalnie

${ }^{1}$ Anne Hudson Jones, Literature and medicine: an evolving canon, „The Lancet” 1996, s. 1360. 
skomplikowaną, w której trudno o bezpośrednią komunikację dotyczącą faktów. Pacjent pod wpływem psychologicznych następstw swojej choroby może „nie być całkiem sobą”. Aby przygotować studentów medycyny do tego - jakże ważnego - aspektu praktyki medycznej, proponuje się im lekturę wielkich dzieł literackich. W 1996 roku Anne Hudson Jones napisała artykuł o związkach literatury i medycyny, w którym omówiła dydaktyczną wartość zajęć z zakresu literatury i rozwój kanonu dzieł literackich wykorzystywanych podczas zajęć na uczelniach medycznych. Pisała o tym, jak w latach 70. XX wieku „literatura pojawiła się na amerykańskich uczelniach medycznych w kontekście zajęć z etyki medycznej"” i wówczas wiele analizowanych tekstów - jak na przykład wybrane opowiadania Richarda A. Selzera ze zbioru Letters to a Young Doctor („Listy do młodego lekarza") - skupiało się na relacji między lekarzem a pacjentem. Analiza tego typu dzieł literackich, jak zauważyła Jones, wzbogaca dyskusję o praktyce medycznej.

$\mathrm{Na}$ początku XXI wieku pojawił się inny nurt dotyczący wykorzystywania literatury w praktyce medycznej. Medycyna narracyjna nie tylko dostrzega wartość literatury jako narzędzia pomagającego uczyć empatii i dostrzegać złożoność leczenia, lecz także wydobywa praktyczne medyczne zastosowania dla umiejętności analizy i interpretacji dzieł literackich. Na przykład według założeń programu Medycyny Narracyjnej $^{3}$ osiągnięcie wzajemnego zaufania w relacji między lekarzem a pacjentem wymaga od lekarza umiejętności uważnego i krytycznego słuchania. Umiejętność tę, uważnego słuchania i rozumienia opowieści pacjenta, można rozwijać poprzez uczenie się uważnego czytania.

Ponieważ niniejszy tom jest poświęcony koncepcji medycyny narracyjnej, celem tego artykułu jest przekazanie Czytelnikom podstawowych informacji na temat jednej z kluczowych umiejętności kształconych w ramach programu Medycyny Narracyjnej, to jest uważnego czytania. Zacznę od krótkiego omówienia nurtu medycyny narracyjnej (oraz zastosowań narracji w medycynie), a następnie przejdę do podsumowania elementów uważnego czytania i tego, w jaki sposób naucza się go w programach Medycyny Narracyjnej.

${ }^{2}$ Ibidem, s. 1360.

3 Chciałabym zaznaczyć, że gdy w artykule piszę „Medycyna Narracyjna”, odnoszę się do programu realizowanego na Uniwersytecie Columbia w stanie Nowy Jork, aby odróżnić go od ruchu (dotyczącego wykorzystania narracji pacjentów w medycynie) jako takiego. 


\section{Medycyna narracyjna}

Koncepcja medycyny narracyjnej, ujęcia praktyki medycznej podkreślającego wartość uważnego i aktywnego słuchania, została stworzona przez Ritę Charon i jej współpracowników na Uniwersytecie Columbia w stanie Nowy Jork. Medycyna narracyjna jest definiowana następująco:

Rozwinięta w roku 2000 na Uniwersytecie Columbia Medycyna Narracyjna wspomaga praktykę kliniczną zdolnościami dostrzegania, wchłaniania, interpretowania opowieści o chorobie oraz doświadczeniem wewnętrznego poruszenia za sprawą tych opowieści. Zdajemy sobie sprawę z tego, że opieka nad chorym rozwija się w opowieściach i uznajemy to, że kluczowym wydarzeniem $\mathrm{w}$ opiece zdrowotnej jest fakt, iż pacjent zdaje o sobie relację, a klinicysta musi ją umiejętnie przyjąć $c^{4}$.

Koncepcja zrodziła się jako efekt studiów Charon nad literaturą angielską, w wyniku których posiadła ona głębszą wiedzę na temat teorii narracji i uwrażliwiła się na obecność narracji w kontekście szpitalnej opieki zdrowotnej ${ }^{5}$. Zachęcona zebranymi osobistymi doświadczeniami i informacjami zwrotnymi od pacjentów, razem z grupą podobnie myślących kolegów i koleżanek zaczęła „eksperymentować z programem nauczania medycyny, włączając do niego działania twórcze” ${ }^{6}$ i opracowała program Medycyny Narracyjnej.

Od początku idea narracyjnego ujęcia w medycynie spotykała się zarówno z uznaniem i poparciem, jak i ze sprzeciwem wobec włączania jej do praktyki klinicznej. Głównymi argumentami przemawiającymi za jej wprowadzeniem są: umocnienie pozycji pacjenta (stawianie jego historii w centrum zainteresowania personelu medycznego), wzmocnienie więzi między lekarzem a pacjentem ${ }^{7}$ oraz przypomnienie lekarzom specjalistom, że praca, którą wybrali, to coś więcej niż tylko biznes ${ }^{8}$. Wszystkie te wymienione korzyści mają na celu poprawę psychologicznego i emocjonalnego samopoczucia nie tylko pacjentów, lecz także pracowników

${ }^{4}$ Narrativemedicine.org, About Narrative Medicine, „Narrative Medicine.org”; https://www.narrativemedicine.org/about-narrative-medicine/ [dostęp 13.10.2019].

${ }^{5}$ Rita Charon, Narrative medicine in the international education of physicians, „La Presse Medicale" 2013, s. 1.

${ }^{6}$ Ibidem, s. 2.

${ }^{7}$ Ibidem.

${ }^{8}$ Sayantani DasGupta, Narrative Medicine, Narrative Humility: Listening to the Streams of Stories, „Creative Nonfiction” Summer 2014. 
służby zdrowia. Kluczowym założeniem tego modelu opieki medycznej jest teza, że ludzie mają naturalną skłonność do konstruowania historii, do myślenia w kategoriach opowieści i spotkanie lekarza z pacjentem nie jest tu wyjątkiem. Szacunek dla pacjenta staje się synonimem szacunku dla jego opowieści, dlatego lekarze powinni wiedzieć, jak reagować na te opowieści, słowem - co z nimi zrobić.

Słychać jednak głosy osób kwestionujących medycynę narracyjną, zalecających ostrożność w podejściu do omawianej koncepcji ${ }^{10}$ czy też wzywających do pogłębienia namysłu nad przesłankami tego nurtu ${ }^{11}$. Zdaniem Galena Strawsona, jednym z głównych argumentów przeciw wykorzystywaniu kategorii narracji w refleksji o człowieku jest błędne założenie, że „wszystkie normalne, nie-patologiczne jednostki ludzkie są z natury rzeczy narratorami i że narracyjność jest kluczowym warunkiem dobrego życia" ${ }^{12}$. Niektórzy ponadto podkreślają (podobnie jak to miało miejsce w odniesieniu do medycznych nauk humanistycznych), że niejasne i szeroko definiowane pojęcia stosowane w obrębie medycyny narracyjnej wymagają dalszej uwagi (np. John Murphy i inni zwracają uwagę na różne typy przymyśleń, spojrzeń w głąb siebie i zaznaczają, że nie każda $z$ takich refleksji jest zbieżna $z$ celami medycyny narracyjnej $\left.{ }^{13}\right)$.

Oprócz tekstów krytycznych i/lub analizujących teoretyczne aspekty medycyny narracyjnej ${ }^{14}, w$ literaturze przedmiotu są także dostępne opracowania badań mających na celu testowanie praktycznych zastosowań programu Medycyny Narracyjnej w programach nauczania na uczelniach medycznych i płynących $z$ tego korzyści. W ramach takich badań w USA, we Francji i w Chinach ${ }^{15}$ zaoferowano studentom możliwość uczestniczenia

${ }^{9}$ Seamus O'Mahony, Against Narrative Medicine, „Perspectives in Biology and Medicine” Autumn 2013; doi: 10.1353/pbm.2013.0032 [dostęp 13.10.2019].

${ }^{10}$ Angela Woods, The limits of narrative: provocations for the medical humanities, „Medical Humanities” December 2011.

${ }^{11}$ John W. Murphy, Berkeley A. Franz, Christian Schlaerth, The Role of Reflection in Narrative Medicine, "Journal of Medical Education and Curricular Development" 2018, s. 1-5.

${ }^{12}$ Galen Strawson, Against Narrativity, „Ratio” December 2004, s. 429.

${ }^{13}$ John W. Murphy i in., The Role of Reflection in Narrative Medicine, "Journal of Medical Education and Curricular Development" 2018, s. 5.

${ }^{14}$ Zob. np.: Iwona Wieżel i in., Is There a Need for Narrative Medicine in Medical Students' Education? A Literature Review, „Medical Science Educator” September 2017.

${ }^{15}$ Zob. np.: T. Wesley i in., Implementing a Narrative Medicine Curriculum During the Internship Year: An Internal Medicine Residency Program Experience, „The Permanente Journal/Perm J" 2018; François Goupy i in., L'enseignement de la médecine narrative 
w kursach medycyny narracyjnej, choć w każdym kraju miało to miejsce na innym etapie kształcenia. Zanotowano także osobiste reakcje studentów i młodych lekarzy na medycynę narracyjną. Przykładem może być opublikowany przez „Scientific American” post autorstwa Samyukty Mullangi, w którym mówi ona o tym, jak jej własne podejście do opowieści pacjentów zmieniało się na przestrzeni kształcenia medycznego. $Z$ uważnej słuchaczki w czasach, gdy była wolontariuszką, podczas obchodów odbywanych $w$ ramach praktyk na studiach medycznych, zmieniła się w kogoś, kto przejmował usłyszane wcześniej historie pacjentów „na własność" i stawał się narratorem opowieści o ich własnym życiu ${ }^{16}$. W zakończeniu swojego tekstu Mullangi podkreśla, że doświadczenie to wpłynęło na jej idealistyczne rozumienie medycyny narracyjnej i pokazało konieczność praktyki oraz podejmowania świadomego wysiłku, aby jako lekarz rzeczywiście uważnie wsłuchiwać się w opowieści pacjentów.

Należy w tym miejscu zaznaczyć, że celem medycyny narracyjnej nie jest „uratowanie” medycyny, nie traktuje też ona literatury jako narzędzia. Uwzględnia natomiast narracyjny charakter medycyny i dostrzega, że każdego dnia pracownicy służby zdrowia (wszyscy, nie tylko lekarze) mają do czynienia z różnymi formami opowieści (takimi jak: historia choroby, dane medyczne, zbierane wywiady; one wszystkie mogą być postrzegane jako rodzaje opowieści). Medycyna narracyjna stanowi interdyscyplinarny ruch, dla którego ,intelektualnymi fundamentami są teoria literatury, narratologia, filozofie kontynentalne, teorie estetyczne i badania kulturowe" ${ }^{17}$. Jak zaznaczają Rita Charon i jej współpracownicy, medycyna narracyjna kieruje się głównie duchem inkluzywności:

[...] nasze działania w obszarze medycyny narracyjnej przekraczają wiele różnych granic, zdajemy sobie sprawę z konieczności podejmowania wysiłku na

peutil être une réponse à l'attente de formation des étudiants à la relation médecin malade? „La Presse Medicale” 2013; Ningxi Yang i in., Does narrative medicine education improve nursing students' empathic abilities and academic achievement? A randomized controlled trial, „Journal of International Medical Research” 2018.

${ }^{16}$ Samyukta Mullangi, Practicing Narrative Medicine, „Scientific American” 2014; https://blogs.scientificamerican.com/guest-blog/practicing-narrative-medicine/ [dostęp 13.10.2019].

${ }_{17}$ Rita Charon i in., Principles and Practice of Narrative Medicine, New York 2017, Kindle book, s. 1/347 (ponieważ Autorka pracuje na wersji e-bookowej na czytnik Kindle'a, w taki sposób podaje numer strony, czyli np. tu: s. 1 z 347 - przyp. red.). 
rzecz budowania mostów między różnicami i poszukiwania przenikalności, udrażniania kanałów, które nieoczekiwanie mogą przynieść korzyści obu stronom. Niezależnie od tego, czy te dwie przeciwstawne strony to psychofarmakologia i psychoanaliza, lekarz i pacjent, kombatant i pielęgniarka czy dwoje czytelników tego samego wiersza, aby możliwe było przekroczenie tego, co jednostkowe czy obronne, konieczne jest podjęcie wysiłku w poszukiwaniu kontaktu z partnerem nie w sporze czy w zgodzie, ale w paradoksie, w kontakcie, którego celem nie jest wykucie odpowiedzi, ale tworzenie naczynia dla myśli ${ }^{18}$.

Ten kontakt, o którym jest mowa w przywołanym fragmencie, staje się dla medycyny narracyjnej istotą medycyny w ogóle, a zdolność do uważnego słuchania, rozumienia i reagowania jest cenna w każdej dziedzinie medycyny:

Wcześnie zdaliśmy sobie sprawę, że uwaga, reprezentacja i afiliacja to trzy ruchy $\mathrm{w}$ medycynie narracyjnej, które wyłoniły się z naszego zaangażowania $\mathrm{w}$ uważne słuchanie, $\mathrm{z}$ wartości reprezentacji pozwalającej dostrzec innego i $z$ wartości partnerstwa rodzącego się w narracyjnym kontakcie. Przez uwagę rozumiemy stan podwyższonego skupienia i zaangażowanie, które słuchacz może podarować mówiącemu - pacjentowi, studentowi, koledze czy przyjacielowi. Wymagająca, ale satysfakcjonująca uwaga sprawia, że słuchający staje się naczyniem, w którym gromadzi się i ujawnia wszystko to, co mówiący ma do powiedzenia. Reprezentacja, zwykle w formie pisemnej, ale także przy użyciu mediów wizualnych, nadaje formę temu, co jest słyszane lub postrzegane, uwidaczniając to na nowo zarówno słuchaczowi, jak i mówiącemu. A afiliacja, rodząca się jako owoc uważnego słuchania i wiedzy uzyskanej w wyniku reprezentacji, wiąże pacjentów z klinicystami, uczniów z nauczycielami, każdego z nas z innym w relacji wspierającej uznanie i działanie, dającej zdolność do towarzyszenia drugiemu niezależnie od tego, co przynosi los. ${ }^{19}$

Kompetencja narracyjna, czyli zdolność rozpoznawania opowieści i wiedza o tym, co należy z tą opowieścią zrobić, staje się zatem kluczowym elementem praktyki medycyny narracyjnej, gdyż „może poszerzyć kliniczne spojrzenie na pacjenta tak, by obejmowało osobiste i społeczne elementy życia pacjentów mające kapitalne znaczenie dla zadania, jakim jest

18 Ibidem, s. $176 / 347$.

19 Ibidem, s. 3/347. 
zdrowienie"20. Jedną z metod rekomendowanych przez medycynę narracyjną w celu rozwijania kompetencji narracyjnej u specjalistów pracujących w służbie zdrowia stanowi uważne czytanie.

\section{Uważne czytanie w programie Medycyny Narracyjnej}

Rita Charon i jej współpracownicy z Uniwersytetu Columbia w ramach programu Medycyny Narracyjnej, realizowanego w formie seminariów i warsztatów, uczą jednego z elementarnych narzędzi analizy tekstu w dziedzinie badań literackich: uważnego czytania. Uczą także tego, jak umiejętność uważnego czytania wpływa na praktykowanie medycyny i pokrewnych dziedzin. Najogólniej rzecz biorąc, uważne czytanie to metoda pracy z tekstem, którą studenci literatury muszą opanować, aby przeprowadzić analizę tekstu pozwalającą zbadać jego szczegóły wykraczające poza to, co można ustalić na podstawie wiedzy z zakresu historii i teorii literatury. Uważne czytanie, czyli staranna lektura, słowo po słowie, pozwala odkrywać i interpretować te aspekty tekstu, które mogą umknąć czytelnikowi przy pobieżnej lekturze. Celem tej analizy jest stawianie pytań dotyczących tekstu, skupianie się na szczegółach, a nie tylko na ogólnych cechach, poszukiwanie i odkrywanie problematyki leżącej u jego podstaw, a także własnej odpowiedzi na wszystkie nasuwające się pytania. Charon pisze tak:

Uważne czytanie stwarza czytelnikowi okazję, by przyjrzał się z uwagą temu, $\mathrm{w}$ jaki sposób on sam nadaje tekstowi znaczenie. Jak działa mój umysł? Jakie stosuje wyćwiczone, wybrane, a może narzucone mu przez los ruchy? Czytelnicy, którzy obserwują siebie samych w procesie czytania, dowiadują się, jak ich własne poznawcze, emocjonalne i charakterologiczne metody razem tworzą znaczenie ${ }^{21}$.

Można tu nakreślić wyraźną paralelę między analizą literacką a medycznym kontaktem z pacjentem, gdyż lekarz, podobnie jak badacz literatury, gromadzi szczegóły i przez zadawanie pytań usiłuje zrozumieć chorobę, z którą ma do czynienia.

W rozdziale Close Reading $\mathrm{w}$ książce The Principles and Practice of Narrative Medicine Rita Charon określa uważne czytanie jako „flagową

20 Ibidem, s. $1 / 347$.

21 Ibidem, s. $170 / 347$. 
metodę w medycynie narracyjnej"22. W praktyce klinicznej umiejętność słuchania jest ważniejsza od umiejętności czytania, ale Charon chce przez to powiedzieć, że uważne czytanie stanowi „poletkio treningowe”23 dla rozwoju umiejętności uważnego słuchania. I wyjaśnia dalej, że adepci medycyny narracyjnej powinni dążyć do

[...] osiągnięcia pełnego, pozbawionego oceny, twórczego odbioru wszystkich aspektów przekazu nadawcy - przekazu składającego się ze słów, momentów zamilknięcia, gestów, postawy, nastroju, wcześniejszych wypowiedzi. Uważny słuchacz absorbuje to, co otrzymuje, i jest w stanie zwrócić mówiącemu swoją reprezentację tego, co usłyszał ${ }^{24}$.

Dlatego właśnie uważne czytanie doskonale nadaje się do nauczania odbioru i interpretacji opowieści pacjentów, gdyż jest to rodzaj analizy literackiej, która skupia się nie tylko na zawartości treściowej (informacyjnej), ale także na strukturze tekstu, panującym w nim nastroju, słownictwie wybranym przez autora po to, by opowiedzieć historię. Uważnemu czytelnikowi, który zwraca uwagę na wszystkie te szczegóły, nie umyka żaden aspekt opowieści ${ }^{25}$.

Wrócę na chwilę do misji medycyny narracyjnej, aby pokazać, na co uważny czytelnik powinien zwracać uwagę. Charon i jej współpracownicy podkreślają, że „Medycyna narracyjna wzmacnia praktykę kliniczną umiejętnością dostrzegania, wchłaniania i interpretowania opowieści o chorobie oraz doświadczeniem wewnętrznego poruszenia za sprawą tych opowieści” ${ }^{26}$. Zawarte w tym fragmencie słowo „wzmacnia” daje do zrozumienia, że celem medycyny narracyjnej jest funkcjonowanie równolegle do standardowej praktyki medycznej i jej wzmacnianie. Co więcej, pojawia się ono po wielokroć w tekstach i wystąpieniach dotyczących medycyny narracyjnej, na przykład w wystąpieniu Charon na konferencji TED w 2011 roku, podczas którego opisała medycynę narracyjną jako „praktykę kliniczną wspomaganą przez wiedzę o tym, co robić z opowieściami"27. Dlaczego to takie ważne? Być może dlatego, że to szczególne

22 Ibidem, s. $157 / 347$.

23 Ibidem, s. $158 / 347$.

24 Ibidem, s. $157 / 347$.

25 Ibidem, s. $181 / 347$.

${ }^{26}$ Narrativemedicine.org, About Narrative Medicine, „Narrative Medicine.org”; https://www.narrativemedicine.org/about-narrative-medicine/ [dostęp 14.10.2019].

27 Rita Charon, Honoring the Stories of Illness, „Tedx Talk Atlanta” 2011. 
określenie wskazuje na to, że medycyny narracyjnej nie należy postrzegać jako koncepcji będącej w opozycji do standardowej praktyki klinicznej, ale jako jej kontrybutor. W słowniku języka angielskiego Merriama i Webstera czasownik fortify został zdefiniowany jako „wzmocnić i zabezpieczyć (miejsce, np. miasto) przy użyciu fortów i artylerii”, ale także - co ważniejsze - „dawać siłę, odwagę i wytrzymałość” oraz „dodawać jakiś materiał w celu wzmacniania lub wzbogacenia” ${ }^{28}$. Ten ostatni element definicyjny szczególnie pasuje do znaczenia czasownika „wzmacniać”, implikowanego w cytowanym fragmencie, pochodzącym ze strony internetowej Columbia Narrative Medicine. Według twórców medycyny narracyjnej wdrażanie jej do praktyki klinicznej przyczynia się do wzbogacenia doświadczeń związanych z tą praktyką zarówno u osób świadczących opiekę zdrowotną, jak i u jej odbiorców (pacjentów). Implikuje możliwość wywierania dodatniego wpływu na ten obszar, dodatkową funkcję, którą można przyjąć lub nie.

Dalej w omawianym fragmencie definiującym medycynę narracyjną wymienione są cztery umiejętności, którymi medycyna narracyjna wspomaga praktykę kliniczną. Są to: zdolność dostrzegania, wchłaniania i interpretowania opowieści oraz doświadczanie wewnętrznego poruszenia za sprawą tych narracji ${ }^{29}$. Warto przyjrzeć się wybranym czasownikom użytym w tym fragmencie. Narracyjna medycyna opiera się na zdolności postrzegania, „formalnego uznawania” opowieści o chorobie i „przyznawania, że uprawnione jest oczekiwanie, że będą one wysłuchane"30. Jedno z podstawowych założeń Medycyny Narracyjnej to uznanie dla opowiadającego i jego historii. Przez prosty akt uznania znaczenia aktu opowiadania historii, nielekceważenia mówiącego i jego opowieści, Medycyna Narracyjna promuje równowagę władzy w obszarze medycyny. W książce The Principles and Practice of Narrative Medicine Charon omawia kwestie związane $z$ hierarchią i asymetrią w medycynie. Jej zdaniem dwie spośród „kilku najważniejszych zasad narracyjnej medycyny”, czyli: „działanie na rzecz sprawiedliwości społecznej” i „metody niehierarchiczne i wspierające współuczestnictwo"31 wspomagają działania na rzecz sprawiedliwości - zarówno w kategoriach równowagi władzy w obrębie

${ }^{28}$ Merriam-Webster, hasło fortify [dostęp 12.05.2019].

29 Narrativemedicine.org, About Narrative Medicine, „Narrative Medicine.org”; https://www.narrativemedicine.org/about-narrative-medicine/ [dostęp 14.10.2019].

30 Merriam-Webster, hasło recognize [dostęp 12.05.2019].

31 Rita Charon i in., Principles and Practice..., op. cit., s. 171/347. 
praktyki medycznej, jak i w lokalnej oraz globalnej sprawiedliwości w opiece zdrowotnej. Dla medycyny narracyjnej dostrzeganie innego, chorego, niezależnie od jego pochodzenia, jest kluczowym elementem sprawiedliwej opieki zdrowotnej.

Następną po zdolności „dostrzegania” jest zdolność „wchłaniania” (ang. absorb) opowieści o chorobie. Tu także wybór określenia jest znaczący: absorb w tym przypadku sugeruje „pochłanianie” oraz „przyjmowanie bez odrazy czy echa” ${ }^{32}$. Także w języku polskim słowo „wchłanianie” (jako odpowiednik ang. absorb) może budzić skojarzenia z namaczaniem, wciąganiem (tak jak gąbka może wchłaniać wodę) lub przenikaniem/wbudowywaniem mniejszej części w większą całość (można np. wchłaniać informacje, czyli przyjmować je i rozumieć). Niezależnie od kontekstu czasownik absorb wskazuje na działanie polegające na uwewnętrznianiu czegoś. Słowo to pochodzi z łaciny, jak sugeruje słownik Merriama-Webstera, i składa się z cząstek ab- („od”, „z”) i -sorbere („wciągać”, „wchłaniać”). Wchłanianie czyjejś opowieści o chorobie oznacza zatem jej uwewnętrznianie, przyjmowanie jej do siebie, bez przerywania, przynajmniej początkowo.

Po „dostrzeganiu” i „wchłanianiu” opowieści przychodzi czas na jej „interpretowanie”. Interpretowanie kojarzy się z reakcją na coś i zgodnie $z$ definicją słowa interprete podaną w słowniku Merriama-Webstera znaczy „działanie polegające na wyjaśnianiu znaczenia czegoś lub reprezentowaniu tego czegoś w sposób artystyczny i subiektywny”. Interpretować może i lekarz, i tancerz: lekarz interpretuje wyniki badań pacjenta, a tancerz interpretuje znaczenie (powiedzmy: śmierci), stosując odpowiednie ruchy ciała, mimikę itd. $\mathrm{W}$ obu przypadkach warunkiem interpretacji jest reakcja interpretującego, rozumienie i korzystanie ze swoich zdolności twórczych. Interpretacja, innymi słowy, to rodzaj komunikatu o tym, jak interpretujący zrozumiał interpretowany przedmiot.

Przedstawione wyżej akapity stanowią przykład dokładniejszej analizy i interpretacji znaczenia pierwszego zdania tekstu wyrażającego misję Medycyny Narracyjnej. Skupiłam się tu jedynie na doborze słów. Oprócz doboru słownictwa uważne czytanie uwzględnia także inne aspekty tekstu. Jak pisze Charon w The Principles and Practice of Narrative Medicine, są one następujące: czas, przestrzeń, głos i metafora. Czytelnik może skupiać się na tylko jednym aspekcie (to znaczy analizować na przykład tylko głos zastosowany w danym tekście) lub na wszystkich po kolei.

${ }^{32}$ Merriam-Webster, hasło absorb [dostęp 12.05.2019]. 


\section{Metoda nauczania uważnego czytania w programie Medycyny Narracyjnej}

W czasie zajęć z Medycyny Narracyjnej studenci mogą zostać poproszeni o przyjrzenie się wybranemu aspektowi omawianego materiału (tekstu), to znaczy wykonują zadania polegające na uważnym czytaniu, kreatywnym pisaniu $\mathrm{W}$ reakcji na tekst i na zadany temat, a następnie odbywają dyskusję nad przygotowanymi pracami pisemnymi. Wszystko to razem stanowi trójstopniową analizę tekstu. Dwa początkowe etapy są wykonywane indywidualnie, a ostatni polega na dzieleniu się swoimi wrażeniami i przemyśleniami z innymi uczestnikami zajęć. Tym sposobem osoba analizująca tekst zyskuje wiele okazji do refleksji i może zobaczyć, czy jej odbiór tekstu jest podobny do tego, jak odbierają go inni.

Pierwszym krokiem do przygotowania takich zajęć jest wybór materiału do analizy. Choć Charon za równie wartościowe uważa teksty literackie (powieści, wiersze), sztuki wizualne (obrazy) czy muzykę, to uważne czytanie w ramach krytyki literackiej odbywa się z wykorzystaniem fragmentów tekstów. Analizowany tekst nie musi bezpośrednio dotyczyć kwestii medycznych - w czasie warsztatów Medycyny Narracyjnej, jak proponuje Charon, chodzi jedynie o to, by wybrany tekst był dostatecznie złożony, aby wywoływać u czytelnika rozmaite reakcje i pobudzać do zadawania pytań, a także, aby przy ponownej lekturze ujawniał nowe aspekty i pozwalał czytelnikowi na zmianę i rozwój interpretacji ${ }^{33}$. Ponadto Charon sugeruje, że należy korzystać z tekstów dotyczących kwestii władzy i pozbawienia władzy, dyskryminacji i przemocy. Jej zdaniem mają one szczególne znaczenie w medycynie narracyjnej, gdyż wiążą się z jednym $z$ głównych założeń tej koncepcji: $z$ działaniami na rzecz sprawiedliwości społecznej ${ }^{34}$.

Gdy tekst zostanie już wybrany, można przystąpić do uważnej lektury. Tekst czytany jest kilkakrotnie, za każdym razem z uwagą skupioną na określonym jego aspekcie. Gdybym miała na przykład zająć się esejem Before I go („Zanim odejdę”) autorstwa doktora Paula Kalanithiego, opublikowanym w „Stanford Medicine” w 2015 roku, mogłabym analizować formę jego tekstu, stosowany głos i sposób, w jaki autor odnosi się do czasu. Mogłabym uznać, że Kalanithi sprawia wrażenie autora świetnie

33 Ibidem, s. $182 / 347$.

${ }^{34}$ Ibidem, s. $171 / 347$. 
zdającego sobie sprawę $z$ tego, co i jak pisze. W jednym $z$ akapitów zadumał się nad formami czasownika „być”: „Jak jest poprawnie: «jestem neurochirurgiem», «byłem neurochirurgiem», «byłem dawniej neurochirurgiem i jeszcze nim będę»?"35. W kontekście całego eseju i sytuacji doktora Kalanithiego (zdiagnozowano u niego nieuleczalny nowotwór) ustęp ten nabiera nowego znaczenia. Autor snuje rozważania nad mocą słów: jak wybierane przez nas słowa kreują naszą tożsamość i lokują nas w czasie.

Następnie, zgodnie $z$ modelem proponowanym przez Charon ${ }^{36}$, „facylitator" ${ }^{37}$, czyli osoba prowadząca zajęcia $\mathrm{w}$ formie dyskusji, podaje uczestnikom temat wypowiedzi pisemnej - „im bardziej budzący bogate skojarzenia i niejednoznaczny, tym lepiej" ${ }^{38}$. Wziąwszy jako przykład esej Before I go doktora Kalanithiego, mógłby on brzmieć na przykład tak: „W jaki sposób doświadczasz siebie w czasie?”. Temat pracy pisemnej stanowi jedynie zachętę do przystąpienia do pisania dla tych, którzy nie bardzo wiedzą, o czym by mieli pisać. Ten etap analizy, polegający na twórczym bądź reaktywnym (tzn. w reakcji na coś) pisaniu, pozwala uczestnikom zajęć doświadczać aktu reprezentacji - pozwalają sobie pisać w odpowiedzi na przeczytany tekst i tym sposobem nadają formę swoim interpretacjom. W świetle tej metody nie ma właściwych ani błędnych reakcji, gdyż przede wszystkim

[...] odbiorca relacji innej osoby może jedynie przybliżać, zgadywać, co nadawca mógł mieć na myśli, i zadziwiać się tym. Ten odbiorca jest również wrażliwy na wpływ, jaki opowieść ma na niego samego - podważa jego przekonania, wzmacnia przyjęte założenia, wzbudza własne niepokoje, przywołuje wspomnienia, sprawia przyjemność, zadaje ból ${ }^{39}$.

Ponadto „W nauczaniu i uczeniu się uważnego czytania należy pamiętać o otwartości na różne indywidualne interpretacje, przeciwstawne

35 Paul Kalanithi, Before I go, „Stanford Medicine” Spring 2015; https:/stanmed. stanford.edu./2015spring/before-i-go.html [dostęp 13.10.2019].

${ }^{36}$ Warto dodać, że Rita Charon stanowczo podkreśla $\mathrm{w}$ książce The Principles and Practice of Narrative Medicine, że zaproponowany przez nią schemat nie jest jedyną dopuszczalną metodą nauczania uważnego czytania w medycynie narracyjnej.

37 Rita Charon i in., Principles and Practice..., op. cit., s. 184/347.

38 Ibidem, s. $184 / 347$.

39 Ibidem, s. 173/347. Fragment ten odnosi się do tolerowania niejednoznaczności i koncepcji narracyjnej pokory autorstwa Sayantani DasGupty, zasady przyjętej w programie Medycyny Narracyjnej w ujęciu Rity Charon. 
odczytania i radykalne zmiany sposobu rozumienia tekstu" ${ }^{40}$. W ten sposób realizowane są reguły Medycyny Narracyjnej, właściwe dla metod niehierarchicznych i partycypacyjnych.

Ostatnim etapem zajęć dydaktycznych w programie Medycyny Narracyjnej jest dzielenie się przemyśleniami $w$ grupie. Uczestnicy czytają na głos swoje pisemne wypowiedzi powstałe w reakcji na tekst i uczestniczą w dyskusji dotyczącej zarówno wyjściowego tekstu, jak i prac uczestników zajęć. Na tym etapie również wspierane są przyjęte przez Medycynę Narracyjną reguły dotyczące metod partycypacyjnych: każdy $z$ uczestników jest zachęcany do dzielenia się z innymi swoimi myślami. Kultywowanie tego rodzaju inkluzywności i równości w czasie zajęć staje się dla pracowników służby zdrowia impulsem do wdrażania podobnych zachowań w codziennej praktyce klinicznej. Charon sama w licznych wystąpieniach i artykułach opisuje, jak dzieli się z pacjentami swoimi interpretacjami ich historii i prosi ich o informacje zwrotne. Jak dotąd z dobrym skutkiem.

Celem nauczania uważnego czytania jest, według słów Charon:

[...] zwiększenie u uczących się zdolności postrzegania zjawisk, ciekawości słów, wkraczania do obcych światów narracyjnych bez lęku i bez obojętności, by zdobywać wgląd w swoje własne charakterologiczne motywy i wzorce uczestniczące w interpretowaniu opowieści i uczyć się otwartości na piękno, które jest im ofiarowane ${ }^{41}$.

To wkraczanie do obcych światów jest według Johna Murphy'ego i jego współpracowników ${ }^{42}$ nowością wprowadzaną przez Medycynę Narracyjną. Wielu czytelnikom czytanie powieści przypomina wnikanie do innego świata. Podobnie jest z lekarzem, który musi zanurzyć się w świecie pacjenta.

Zaangażowanie literatury w medycynę, szczególnie w nauczanie medycyny, nie jest niczym nowym. Medycyna narracyjna jest ruchem, który stawia sobie określone cele, takie jak szanowanie opowieści pacjenta przez uważne słuchanie, oraz daje wskazówki, jak można wzbogacić praktykęmedyczną o wiedzę i umiejętności dotyczące postępowania z opowieściami

${ }^{40}$ Ibidem, s. $174 / 347$.

${ }^{41}$ Ibidem, s. 205/347.

${ }^{42}$ John W. Murphy, Berkeley A. Franz, Christian Schlaerth, The Role of Reflection..., op. cit., s. 5. 
pacjentów. Na tym etapie rozwoju tej dziedziny za wcześnie jest na szacowanie korzyści płynących z jej stosowania. Jednak rosnąca (także w Polsce) liczba badaczy z różnych dyscyplin i lekarzy specjalistów zabierających głos w dyskusjach na jej temat, a także coraz liczniejsze badania mające na celu obserwowanie efektów wdrażania praktycznych rozwiązań, pozwalają przypuszczać, że wkrótce będziemy mieli do dyspozycji więcej danych. Niemniej jednak z informacji zwrotnych, jakie Charon i jej współpracownicy otrzymują od studentów uczestniczących w warsztatach Medycyny Narracyjnej, wynika, że wysoko oceniają oni kurs uważnego czytania. Jego efekty dostrzegają w swoim życiu osobistym i w relacjach z pacjentami ${ }^{43}$.

Choć można polemizować z założeniem, że ujęcie narracyjne stanowi ten właściwy sposób doskonalenia kontaktu medycznego, motywacje leżące u podstaw tego ruchu sygnalizują, że zarówno specjaliści pracujący w służbie zdrowia, jak i pacjenci nie są zadowoleni z obecnego stanu opieki zdrowotnej. To, że medycyna narracyjna jest wprowadzana do programów nauczania na uniwersytetach medycznych na całym świecie (np. na Uniwersytecie Kartezjusza w Paryżu), zdaje się potwierdzać jej skuteczność. Nauczanie uważnego czytania, zgodnie z propozycją zawartą $\mathrm{w}$ podręczniku The Principles and Practice of Narrative Medicine, wydaje się być metodą, dzięki której można wywołać u studentów medycyny narracyjnej zmianę $\mathrm{w}$ postrzeganiu i przyjmowaniu opowieści oraz $\mathrm{w}$ jakości budowanych relacji z pacjentami. Według założeń Medycyny Narracyjnej opanowanie umiejętności uważnego czytania może pomóc specjalistom lepiej dostroić się do opowieści pacjentów, łatwiej je dostrzegać, trafniej interpretować oraz właściwiej na nie reagować. A wszystko to sprowadza się do budowania wzajemnego zaufania $\mathrm{w}$ relacji z pacjentem, które jest niezbędne, aby leczenie się powiodło.

(przekład Elżbieta Józefowicz)

\section{Bibliografia}

Charon R., Honoring the Stories of Illness, „Tedx Talk Atlanta” 2011; https://youtu. be/24kHX2HtU3o [dostęp 15.10.2019].

Charon R., Narrative Medicine in the international education of physicians, „Presse Med” 2013, 42(1), s. 3-5; doi:10.1016/j.lpm.2012.10.015 [dostęp 15.10.2019].

43 Ibidem, s. 205, 347. 
Charon R. i in., Principles and Practice of Narrative Medicine, Oxford University Press, New York 2017.

DasGupta S., Narrative Medicine, Narrative Humility: Listening to the Streams of Stories, „Creative Nonfiction” Summer 2014; https://www.creativenonfiction.org/online-reading/narrative-medicine-narrative-humility [dostęp 13.10.2019].

Goupy F. i in., L'enseignement de la médecine narrative peutil être une réponse à l'attente de formation des étudiants à la relation médecin malade?, „La Presse Medicale” 2013, 42(1), s. e1-e8; doi: 10.1016/j.lpm.2012.09.012 [dostęp: 13.10.2019].

Hudson Jones A., Literature and medicine: an evolving canon, „The Lancet” 1996, Vol. 348, s. 1360-1362; doi: 10.1016/S0140-6736(96)09219-7 [dostęp: 13.10.2019].

Kalanithi P., Before I go, „Stanford Medicine”, Spring 2015; http://stanmed.stanford. edu/2015spring/before-i-go.html [dostęp: 13.10.2019].

Mullangi S., Practicing Narrative Medicine, „Scientific American” 2014; https://blogs. scientificamerican.com/guest-blog/practicing-narrative-medicine/?redirect $=1$ [dostęp: 13.10.2019].

Murphy J.W., Franz B.A., Schlaerth Ch., The Role of Reflection in Narrative Medicine, "Journal of Medical Education and Curricular Development" 2018, Vol. 5, s. 1-5; doi: 10.1177/2382120518785301 [dostęp: 15.10.2019].

Narrativemedicine.org, About Narrative Medicine, „Narrative Medicine.Org”; https:// www.narrativemedicine.org/about-narrative-medicine/ [dostęp 13.10.2019].

O'Mahony S., Against Narrative Medicine, „Perspectives in Biology and Medicine” Autumn 2013, Johns Hopkins University Press, Vol. 56, s. 611-619; doi: 10.1353/ pbm.2013.0032 [dostęp 13.10.2019].

Strawson G., Against Narrativity, „Ratio” December 2004, s. 428-452.

Wesley T., Hamer D., Karam G., Implementing a Narrative Medicine Curriculum During the Internship Year: An Internal Medicine Residency Program Experience, „The Permanente Journal/Perm J" 2018; doi: 10.7812/TPP/17-187 [dostęp 15.10.2019].

Wieżel I., Horodeńska M., Domańska-Glonek E., Torres K., Is There a Need for Narrative Medicine in Medical Students' Education? A Literature Review, „Medical Science Educator", September 2017, s. 559-565; doi: 10.1007/s40670-017-0426-0 [dostęp 15.10.2019].

Woods A., The limits of narrative: provocations for the medical humanities, „Medical Humanities" December 2011, 37(2), s. 73-78; doi: 10.1136/medhum-2011-010045 [dostęp 15.10.2019].

Yang N. i in., Does narrative medicine education improve nursing students' empathic abilities and academic achievement? A randomized controlled trial, „Journal of International Medical Research" 2018, Vol. 46(8), s. 3306-3317. 
A B S T R A C T

\section{The method of close reading in narrative medicine}

This text aims to provide the reader with a general overview of one of Narrative Medicine's methods, namely close reading, which, as Rita Charon et al. in The Principles and Practice of Narrative Medicine propose, can be used to develop narrative competence, teach healthcare professionals the ability to recognize and know what to do with stories. This form of textual analysis, typically utilized by literary scholars, is thought to help people working in healthcare to develop skills that could positively influence their professional relationship with their patients.

KEY WORDS: textual analysis, narrative medicine, teaching methods, close reading, medical humanities

\section{A B S T R A K T}

\section{Metoda uważnego czytania (close reading) w medycynie narracyjnej}

Celem artykułu jest omówienie zastosowania metody uważnego czytania (ang. close reading) $\mathrm{w}$ medycynie narracyjnej. Close reading jest jednym $\mathrm{z}$ narzędzi stosowanych przez literaturoznawców do przeprowadzania analizy tekstu, obejmującej m.in. takie elementy, jak: dobór słownictwa, ton tekstu, spojrzenie na badany fragment pod kątem określonego motywu (np. czasu, miejsca). Według założeń medycyny narracyjnej, przedstawionych przez Ritę Charon i in. w monografii Principles and Practice of Narrative Medicine, opanowanie przez lekarzy umiejętności uważnego czytania może pozytywnie wpływać na ich komunikację z pacjentami.

SŁOWA KLUCZOWE: analiza tekstu, medycyna narracyjna, metody nauczania, uważne czytanie, medyczne nauki humanistyczne 


\section{NARRACJE \\ W DYSKURSIE MEDYCZNYM}


Magdalena Zabielska

Uniwersytet im. Adama Mickiewicza

Magda Żelazowska-Sobczyk

Uniwersytet Warszawski

\section{„Pamiętam, zdarzyło się to w sobotę rano, około 10". Fachowe publikacje medyczne oparte na relacjach pacjentów i lekarzy}

W międzynarodowych fachowych czasopismach medycznych coraz częściej pojawiają się całe publikacje lub ich części, pokazujące punkt widzenia zarówno pacjentów, jak i innych uczestników procesu diagnozy i leczenia. Nie roszczą sobie one prawa do bycia tekstami naukowymi, ale zwracają uwagę na perspektywy wcześniej wyłączone z szeroko pojętej praktyki medycznej. Celem niniejszego artykułu jest zaprezentowanie owych publikacji, ich genezy oraz wagi, jaką mają w kontekście rozwoju zawodowego lekarza. Najpierw zostaną pokrótce omówione znaczenie samej relacji ${ }^{1}$ w życiu człowieka oraz rozwój badań narracyjnych w naukach humanistycznych. Podkreślony będzie również narracyjny charakter samej profesji - medycyny. Następnie zaprezentowane zostaną fragmenty konkretnych publikacji opartych na relacjach, ze szczególnym uwzględnieniem subiektywnego przedstawienia doświadczenia pacjenta i/lub lekarza. W tym kontekście na uwagę zasługuje osobna grupa tekstów z gatunku medycznego opisu przypadku i ich ewolucja. Pacjent występował w nich początkowo $\mathrm{w}$ trzecioosobowej narracji lekarza, wypowiadającego się w imieniu chorego, następnie w osobnych częściach artykułów zawierających pierwszoosobową relację osoby leczonej, a w końcu pojawiły się całe teksty poświęcone doświadczeniu pacjenta.

${ }^{1}$ W niniejszym artykule słowo „relacja” będzie używane głównie w odniesieniu do wypowiedzi pacjentów i lekarzy, a nie jako określenie związku między nimi. 


\section{Narracja i jej znaczenie w życiu człowieka}

Szukanie schematów i wzorców zachowań oraz związków przyczynowo-skutkowych między zdarzeniami jest domeną typowo ludzką. Według Kathryn Montgomery Hunter:

[...] jesteśmy istotami narracyjnymi. Ludzkie życie jest przeniknięte przez opowieści: czytamy, opowiadamy i słuchamy historii, widzimy je rozwijające się w sztuce i życiu społecznym; odgrywamy je sami; nadają kształt i znaczenie naszej codziennej egzystencji. Przeszłość jest zachowana w dużym stopniu jak opowieść, a wizje przyszłości, jeśli mają mieć siłę przekonywania, są również opowieściami ${ }^{2}$.

Autorka tym samym podkreśla rolę opowieści w kształtowaniu ludzkiego życia. Nie tylko jesteśmy nimi otoczeni, ale również sami je tworzymy na co dzień. Jest to swego rodzaju aktywność nadająca formę i treść naszej egzystencji. W naukach humanistycznych i społecznych ów punkt zwrotny $\mathrm{w}$ postrzeganiu roli narracji miał miejsce w latach 70 . ubiegłego wieku (był to tzw. zwrot ku opowieści, ang. narrative turn). To wtedy historycy doszli do wniosku, że historii się nie odkrywa, ale się ją tworzy; politolodzy docenili rolę narracji w zdobywaniu kapitału wyborczego, a psycholodzy podkreślali rolę spójności narracji człowieka w jego codziennej egzystencji ${ }^{3}$. W socjolingwistyce z kolei William Labov i Joshua Waletzky ${ }^{4}$ nie tylko zwrócili uwagę na to, iż opowieści nie są domeną wyłącznie pisarzy, lecz także stworzyli kryteria strukturalne definiujące opowieść.

\section{Narracyjny charakter medycyny}

O ile w mediach, w kontekście politycznym (polityków i ich programów wyborczych), narracja jest często rozumiana jako metoda uzyskiwania głosów wyborców poprzez przedstawienie danych wydarzeń w konkretny sposób, o tyle jej rola w szeroko pojętym kontekście medycznym jest nieco

${ }^{2}$ Kathryn Montgomery Hunter, Narrative, literature, and the clinical exercise of practical reason, „The Journal of Medicine and Philosophy” 1996, s. 303.

3 Por. Amanda Barusch, Refining the Narrative Turn: When does story-telling become research?, referat wygłoszony na konferencji Gerontological Society of America, 16 listopada 2012, San Diego; http://www.amandabarusch.com [dostęp 27.05.2018].

${ }^{4}$ William Labov, Joshua Waletzky, Narrative analysis: Oral versions of personal experience, w: Essays on the verbal and visual arts, Seattle 1967, s. 12-44. 
inna. Lekarze i pacjenci są niejako „zanurzeni” ${ }^{5}$ w tej aktywności, w której „każdy mówi coś drugiej osobie”6. Jak zauważa Tomasz Pasierski, „kontakt lekarza z pacjentem rozpoczyna się od rozmowy"7. Opowieści mogą być tworzone zarówno przez lekarzy, jak i przez pacjentów (możliwe są również konfiguracje $z$ udziałem studentów medycyny lub rodziny pacjenta), a sama relacja ma charakter dialogowy, gdyż opowieści pacjentów są dalej przekazywane innym lekarzom, a lekarze z kolei mogą dzielić się ze sobą swoimi opowieściami ${ }^{8}$. Co więcej, według Davida Hatema oraz Elizabeth A. Rider:

[...] opowieść jest integralną częścią wielu aktywności w kontekście medycznym. Opowieść to podstawa opieki medycznej poprzez relacje pacjentów, którzy dzielą się nimi ze swoimi lekarzami, i poprzez relacje lekarzy, którzy je konstruują w stosunku do pacjenta ${ }^{9}$.

Dalej autorzy dodają:

[...] można powiedzieć, że praktyka medyczna jest niejako przeżywana poprzez relacje - „czułem się dobrze dopóty, dopóki...” oraz „to wszystko zaczęło się, kiedy..." to częsty sposób rozpoczęcia wizyty u lekarza ${ }^{10}$.

Przedstawione wyżej fragmenty skłaniają do wniosku, że każda choroba pacjenta to swego rodzaju przypadek, który ma swoją opowieść. Co ciekawe, o ile dzisiejszy rynek wydawniczy obfituje w opowieści mieszczące się w szeroko rozumianej tematyce medycznej (chodzi m.in. o takie publikacje, jak: Ludzie czy bogowie. 27 rozmów $z$ najstynniejszymi polskimi lekarzami ${ }^{11}$,

${ }^{5}$ Lewis Mehl-Madrona, The nature of narrative medicine, „The Permanente Journal" 2007, s. 83.

${ }^{6}$ Richard Kearney, On stories, New York 2002, s. 5.

7 Tomasz Pasierski, Choroba jako opowieść, „Medycyna po Dyplomie” 2008, s. 68.

${ }^{8}$ Por. Magdalena Zabielska, Magda Żelazowska, Narracyjny charakter medycznego opisu przypadku a jego spójność, w: Spójność tekstu specjalistycznego (2), Warszawa 2015, s. 125; http://www.sn.iksi.uw.edu.pl/documents/7732735/0/ SN+34+M_Górnicz+M_Kornacka+Spójność\%20tekstu+specjalistycznego+2.pdf [dostęp 29.10.2018]; Patrycja Zurzycka, Teresa Radzik, Medycyna narracyjna - zarys problematyki, „Problemy Pielęgniarstwa” 2015, s. 432.

${ }_{9}^{9}$ David Hatem, Elizabeth A. Rider, Sharing stories: Narrative medicine in an evidence-based world, „Patient Education and Counseling” 2004, s. 251.

${ }^{10}$ Ibidem, s. 251.

${ }^{11}$ Krystyna Bochenek, Dariusz Kortko, Ludzie czy bogowie. 27 rozmów z najstynniejszymi polskimi lekarzami, Warszawa 2015. 
Mali bogowie. O znieczulicy polskich lekarzy ${ }^{12}$ czy Będzie bolato. Sekretny dziennik młodego lekarza ${ }^{13}$ ), o tyle opowieścią można też nazwać relację z pobytu pacjenta $\mathrm{w}$ szpitalu czy opis przypadku, gdzie również mamy do czynienia z konkretnym bohaterem i sekwencją wydarzeń ${ }^{14}$. Ów narracyjny charakter medycznego opisu przypadku jako gatunku tek$\mathrm{stu}^{15}$ jest ważny ze względu na postępującą dehumanizację medycyny. Jak słusznie zauważa David Enoch: „Opis przypadku przypomina nam, że osoba nie jest zwyczajną cyferką, ale stanowi umysł, ciało i duszę i każdy $z$ tych elementów musi być brany pod uwagę, aby całkowicie pacjenta wyleczyć" ${ }^{\prime 16}$.

\section{Publikacje oparte na relacjach pacjentów i lekarzy}

W związku ze wspomnianym wcześniej zwrotem ku narracji, w ostatnich latach można obserwować coraz większą obecność w fachowych czasopismach medycznych, włącznie $z$ tymi dostępnymi jedynie $\mathrm{w}$ formie elektronicznej, różnego rodzaju publikacji opartych na narracji. Są to krótkie formy lub też całe artykuły zawierające relacje pierwszoosobowe. Mogą to być zarówno relacje pacjentów, prezentujące subiektywne doświadczenie choroby, tzw. patografie ${ }^{17}$, jak i relacje lekarzy czy studentów medycyny, wyrażające w przeważającym stopniu biomedyczną perspektywę choroby. Redaktorzy czasopism zachęcają do przysyłania tego typu publikacji, które mogą mieć charakter „osobistych winiet (badających dynamikę relacji pacjent-lekarz) zaczerpniętych $\mathrm{z}$ różnorodnych doświadczeń w kontekście medycznym”, a także „oryginalnych, subiektywnych form wyrazu,

${ }^{12}$ Paweł Reszka, Mali bogowie. O znieczulicy polskich lekarzy, Warszawa 2017.

${ }^{13}$ Adam Kay, Będzie bolało. Sekretny dziennik mtodego lekarza, Kraków 2018.

${ }^{14}$ Współczesne medyczne opisy przypadku w języku angielskim obejmujące różne dziedziny medycyny zbadała z perspektywy narracyjnej Magdalena Murawska: The many narrative faces of medical case reports, „Poznań Studies in Contemporary Linguistics" 2012, s. 1.

${ }^{15}$ Por. Magdalena Zabielska, Magda Żelazowska, Narracyjny charakter... , op. cit.; Gerald Prince, Narratology. The form and functioning of narrative, Berlin 1982; Trygve Nissen, Rolf Wynn, The clinical case report: A review of its merits and limitations, „BMC Research Notes" 2014, s. 1.

${ }^{16}$ M. David Enoch, Case reports (Letter), „British Journal of Psychiatry” 2005, s. 169.

${ }^{17}$ Anne Hunsaker Hawkins, Reconstructing Illness: Studies in Pathography, West Lafayette 1993. 
poruszających doświadczenia $w$ formie poezji lub prozy"18. Wśród aktualnych i byłych tytułów serii zawierających tego typu teksty wymienić należy opisy przypadku publikowane w sekcji Patient's perspective $\mathrm{z}$ "Journal of Medical Case Reports” oraz "Cases Journal”, serię On being a doctor/patient $\mathrm{z}$ „Annals of Internal Medicine”, Reflective practice $\mathrm{z}$ „Patient Education and Counselling", A piece of my mind $z$,Journal of American Medical Association", On my mind z "Journal of American Medical Association Pediatrics” oraz cykle Personal view i What your patient is thinking $z$,British Medical Journal”. Wszystkie wymienione tytuły - poza pierwszym - to publikacje, które w całości są narracjami pacjenta lub lekarza. Opisy przypadku publikowane w sekcji Patient's perspective (,Journal of Medical Case Reports” oraz "Cases Journal”) to swego rodzaju kombinacja tekstu fachowego (stanowiącego objętościowo większość publikacji) oraz zazwyczaj pierwszoosobowej relacji pacjenta lub ewentualnie jego rodziny, uzupełniającej fachowy raport medyczny. Ten i inne warianty medycznych opisów przypadku opartych na narracji zostaną omówione w następnej części tekstu. Prezentowane w niniejszym artykule fragmenty publikacji pochodzą ze zbioru prestiżowych brytyjskich i amerykańskich specjalistycznych czasopism medycznych (obejmujących lata 2002-2009) i stanowią przykłady omawianych tekstów opartych na narracji. Odzwierciedlają również kierunek ich ewolucji dotyczącej perspektywy, z jakiej prezentowane jest $\mathrm{w}$ nich doświadczenie choroby przez pacjenta, oraz jego znaczenie na tle całej publikacji.

Dalej zostaną zaprezentowane przykładowe fragmenty wybranych publikacji opartych na narracjach, które następnie zostaną omówione pod kątem prezentowanych w nich treści oraz warstwy językowej. Będą to kolejno: interaktywne opisy przypadku, opisy przypadku oparte na faktach i narracji (gdzie czytelnik ma do czynienia z połączeniem tekstu fachowego i osobistej relacji pacjenta lub/i lekarza) oraz publikacje, które w całości są osobistymi relacjami tychże osób, tj. nie zawierają tekstu naukowego.

${ }^{18}$ JAMA Instruction for authors 1\&2; http://jama.jamanetwork.com/ public/ instructionsForAuthors.aspx\#CategoriesofArticles, http://archpedi.jamanetwork. com/ public/instructionsForAuthors.aspx\#SecCategoriesofArticles [dostęp 27.09.2018]. 


\section{Interaktywne opisy przypadku}

Opis przypadku jako gatunek w obrębie komunikacji medycznej można zdefiniować jako opis nowej jednostki chorobowej u jednego pacjenta lub kilku pacjentów albo też jako opis wybranego nowego aspektu diagnozy i/lub leczenia danej jednostki chorobowej. Funkcją opisu przypadku jest rozpowszechnianie wiedzy oraz jej zastosowanie w kontekście pedagogicznym. Interaktywny opis przypadku jako odmiana tego gatunku został zainicjowany przez czasopismo „British Medical Journal” w 2003 roku. Charakteryzował się trójczłonową strukturą oraz interaktywnością rozumianą w dwojaki sposób. Jeśli chodzi o strukturę, to jedna publikacja składała się z trzech części: „Prezentacji przypadku” (ang. Case presentation), „Postępów” (ang. Case progress) oraz „Wyników leczenia” (ang. Case outcome), w których stopniowo przekazywano informacje o danym przypadku chorobowym i zachęcano czytelników do bieżącego komentowania i sugerowania diagnozy. Interaktywność z kolei polegała z jednej strony na swoistej interakcji między autorami tekstu a czytelnikami, z drugiej zaś - na włączeniu do tekstu specjalnej części zatytułowanej „Perspektywa pacjenta” (ang. Patient's perspective), w której osoba leczona otrzymywała szansę przedstawienia, w formie pierwszoosobowej narracji, swoich odczuć i doświadczeń z przebytego leczenia. Przedsięwzięcie zaowocowało kilkoma seriami artykułów z mniej lub bardziej licznymi komentarzami (ze strony czytelników i specjalistów) na łamach samego czasopisma. Ostatecznie jednak zostało zakończone ze względu na czasochłonność procesu przygotowania trzyczęściowej publikacji oraz interakcji z czytelnikami. Należy jednak przyznać, że projekt ten cieszył się uznaniem zarówno redaktorów, wspomnianych specjalistów, jak i w dużej mierze pacjentów. Był jedną z pierwszych form specjalistycznego gatunku medycznego włączającego do medycznych rozważań pacjenta jako źródło informacji istotnych klinicznie. Niżej przedstawiono dwa wybrane fragmenty przykładowego interaktywnego opisu przypadku, z części poświęconej doświadczeniu pacjenta:

a) Kiedy zostałem przyjęty, widok krwi wypływającej z klatki piersiowej, kiedy założono mi rurkę, naprawdę mnie przerazi1 ${ }^{19}$.

${ }^{19}$ Shihas Salim, Prasanthi Ganeshram, Amish D. Patel, Anita A. Kumar, Divya Vemuri, Vijay Jeyachandran, Deepan Rajamanickam, Ghanshyam P.S. Shantha, Unilateral hemothorax in a 46 year old South Indian male due to a giant arteriovenous 
b) Rezonans magnetyczny był również stresującym doświadczeniem, bycie zamkniętym w małej przestrzeni $z$ tym hałasem przez tak długo. Udało się to dopiero po dodatkowym leku².

W przedstawionych przykładach novum stanowi zarówno treść, tj. opis doświadczenia choroby, jak i forma, przede wszystkim słownictwo (ogólne, niemedyczne) wyrażające subiektywną perspektywę pacjenta, np. „przerażać”, „stresujący” czy „rurka”.

\section{Opisy przypadku oparte na faktach i narracji}

Opis przypadku oparty na faktach i narracji (ang. evidence and narrative based case report) był odmianą, która pojawiła się nieco wcześniej niż opisy interaktywne, jednak autorkom niniejszej pracy udało się dotrzeć tylko do jednej tego typu publikacji, wydanej przez „British Medical Journal”. Specyfiką tej odmiany jest kombinacja opisu przypadku i narracji, jednak w nieco innym wydaniu niż w późniejszych opisach interaktywnych. Chodzi o to, że część narracyjna zawiera zarówno relację pacjenta, jak i lekarza, stanowiąc swego rodzaju dialog między tymi dwiema osobami, co ilustrują następujące fragmenty:

c) Czuję, że mam depresję teraz, kiedy ostatecznie, ponownie, stanę się tą samą słabą osobą, którą byłam na początku swojego życia... i zwyczajnie nie chcę i nie zaakceptuję tego ${ }^{21}$.

d) Będąc $w$ pełni świadomym możliwego ryzyka $w$ tym postępowaniu, jej mąż akceptuje jej decyzję. Czuję, że i ja mogę z tym żyć22.

W przedstawionych wyżej przykładach można ponownie zaobserwować pacjenta opisującego rzeczywistość chorobową z własnego punktu widzenia, wyrażającego się m.in. w braku akceptacji tej rzeczywistości.

hemodialysis fistula: a case report, „Cases Journal” 2008, s. 4; http://www.casesjournal. com/content/1/1/225 [dostęp 3.09.2012].

${ }^{20}$ Georgios D. Floros, Ioanna Charatsidou, Grigorios Lavrentiadis, A case of PTSD presenting with psychotic symptomatology: a case report, "Cases Journal” 2008, s. 3; http://www.casesjournal.com/content/1/1/352 [dostęp 3.09.2012].

${ }^{21}$ Shmuel Reis, Doron Hermoni, Pnina Livingstone, Jeffrey Borkan, Integrated narrative and evidence based case report: Case report of paroxysmal atrial fibrillation and anticoagulation, „British Medical Journal” 2002, s. 1019.

${ }^{22}$ Ibidem. 
W podobnym tonie wypowiada się również lekarz, który formułuje swoją osobistą opinię, że „może z tym żyć”; on również nie odwołuje się do faktów medycznych, tylko do swojej własnej percepcji.

Przywołane przykłady, zaczerpnięte zarówno z interaktywnych opisów przypadku, jak i z opisów opartych na faktach i narracji, można analizować z perspektywy czterech wymiarów doświadczenia choroby zaproponowanych przez Moirę Stewart i współautorów ${ }^{23}$. W odniesieniu do cytowanych fragmentów można mówić o wyrażonych w nich odczuciach (ang. patient's feelings), jakie towarzyszą pacjentowi w stanie chorobowym, kiedy opisuje on swoje wrażenia na widok krwi, jak w przykładzie a), lub - co widać w przykładzie b) - kiedy wspomina o trudnościach związanych z wykonywaniem rezonansu magnetycznego, oraz o sposobach zrozumienia przez pacjenta tego, co się z nim dzieje (ang. patient's ideas) - jak w przykładach c) i d). Z kolei w odniesieniu do głównych założeń medycyny narracyjnej, zaproponowanych przez Ritę Charon, tj. uwagi (słuchanie i obserwacja pozawerbalnego zachowania pacjenta), reprezentacji i budowania więzi, uznać należy, że mamy tu do czynienia z reprezentacją ${ }^{24}$. Trzeba jednak uściślić, iż o ile w regularnych opisach przypadku jest to zazwyczaj zdawkowe (kilka wyrazów, dwa lub trzy zdania) odzwierciedlenie w tekście napisanym przez lekarza tego, co powiedział pacjent, o tyle tutaj mamy do czynienia $z$ osobistymi przeżyciami pacjenta spisanymi przez niego samego, ewentualnie wspólnie z lekarzem ${ }^{25}$.

W tym miejscu należy jeszcze wspomnieć, iż fakt, że to akurat medyczny opis przypadku przeszedł ewolucję gatunkową, wzbogacając się o komponent osobistej relacji pacjenta (ewentualnie lekarza), wynika również z jego narracyjnego charakteru ${ }^{26}$. Sam fachowy tekst można sklasyfikować jako swoistą opowieść o konkretnym pacjencie cierpiącym na konkretną chorobę. Owa ewolucja gatunkowa zdecydowanie wpisała się we wspomniany już zwrot ku narracji. Co więcej, oddanie głosu

${ }^{23}$ Moira Stewart, Judith Belle Brown, Wayne Weston, Carol L. McWilliam, Thomas R. Freeman, Exploring Health, Disease and the Illness Experience, w: J.B. Brown, T. Thornton, M. Stewart (red.), Challenges and Solutions: Narratives of Patient-centred Care, London 2012.

${ }^{24}$ Rita Charon, Narrative Medicine: Attention, Representation, Affiliation, „Narrative" 2005.

${ }^{25}$ Magdalena Zabielska, Magda Żelazowska, From breathing difficulty to dyspnea: a translation process from the patient's story to the doctor's report in interactive medical case reports, „Communication \& Medicine” 2017, s. 74.

${ }^{26}$ Gerald Prince, Narratology..., op. cit. 
pacjentowi na łamach specjalistycznej prasy lekarskiej to „uznawanie roli indywidualnych historii pacjentów w procesie terapeutycznym" ${ }^{27}$. Uwaga ta odzwierciedla współczesne paradygmaty praktyki medycznej, $\mathrm{w}$ tym medycynę zorientowaną na pacjenta (ang. patient-centred medicine) i wsparcie pacjenta (ang. patient advocacy), które najpierw odpowiednio uwzględniły aspekt społeczno-psychologiczny życia pacjenta w prawidłowej i kompletnej diagnozie oraz terapii, a potem stopniowo uwzględniały go jako aktywnego uczestnika tych procesów. Na poziomie tekstu włączenie pacjenta $\mathrm{w}$ proces diagnostyczno-terapeutyczny może być sygnalizowane $\mathrm{w}$ fachowych publikacjach poprzez uwzględnienie jego opowieści. Jednak specjalistyczna literatura medyczna nie jest główną areną funkcjonowania narracji pacjentów. To internet (szczególnie fora i blogi) stanowi miejsce, w którym te opowieści są najczęściej publikowane i czytane. Zjawisko to można uznać za przejaw tzw. Medycyny 2.0, która oznacza wszelkiego rodzaju aktywności (zarówno samych pacjentów, jak i lekarzy) z użyciem narzędzi elektronicznych ${ }^{28}$.

\section{Publikacje zawierające w całości narracje lekarzy}

W prezentowanych wcześniej interaktywnych opisach przypadku to pacjenci mieli okazję przedstawiać swój punkt widzenia na różnorodne kwestie medyczne, a lekarze byli autorami obiektywnego, specjalistycznego opisu danego przypadku. Wprawdzie w opisach przypadku opartych na faktach i narracji lekarz także mógł „dyskutować z pacjentem”, jednak nie były to pełne narracje, jakie można zaobserwować właśnie $\mathrm{w}$ trzeciej grupie badanych publikacji, stanowiących w całości osobiste relacje. Publikacje $z$ grup pierwszej i drugiej (tj. odpowiednio interaktywne opisy przypadku i opisy oparte na faktach i narracji) można zaliczyć do narracji współtworzonych przez osobę leczącą i osobę leczoną ${ }^{29}$. W artykułach

${ }^{27}$ Tomasz A. Karkowski, Dorota Karkowska, Paweł Skoczylas, Medycyna personalizowana a medycyna narracyjna, w: Ekonomiczne, medyczne $i$ prawne aspekty zdrowia publicznego, Łódź 2016, s. 92.

${ }^{28}$ Gunther Eysenbach, Medicine 2.0: social networking, collaboration, participation, apomediation, and openness, ,Journal of Medical Internet Research” 2008; http://asset. jmir.pub/assets/8eacc4947ad0366ffc293913ea261bf8.pdf [dostęp 8.10.2018]; Tomasz Goban-Klas, Media. Od oglądania do wyszukiwania, w: idem (red.), Komunikowanie $w$ ochronie zdrowia - interpersonalne, organizacyjne i medialne, Warszawa 2014, s. 187-194.

${ }^{29}$ Ibidem, s. 430. 
zawierających w całości narracje nie tylko pacjenci, lecz także lekarze prezentują swoje subiektywne doświadczenia - dotyczą one ich relacji z pacjentem lub dotykają kwestii związanych $z$ wykonywanym zawodem i jego uwarunkowaniami ${ }^{30}$. Fragmenty przywołane w tej części artykułu są opowieściami o ich tożsamości jako lekarzy, a zawarte w nich narracje przedstawiają perspektywę pracowników służby zdrowia i poruszają różne, istotne dla nich tematy:

e) Trzy miesiące później wróciła do naszego gabinetu praktycznie bez żadnych oznak bólu. Była niczym jasny promyk słońca, oznajmiając z uśmiechem, że już nie cierpi z powodu strasznego bólu ${ }^{31}$.

f) Czy pragniemy szacunku i poczucia władzy? Tytuł „dr” jest tytułem, który wzmacnia poczucie naszej wartości od pokoleńn ${ }^{32}$.

g) Chociaż zdecydowanie wolałbym nigdy nie doświadczyć, co znaczy być pacjentem, okazało się to niesamowicie pouczające. Miałem wgląd, jak to jest być po tej drugiej stronie w relacji lekarz-pacjent i część z tego, czego się nauczyłem, bardzo mnie zaskoczyła ${ }^{33}$.

Kiedy redaktorzy czasopisma „Patient Education and Counseling” wprowadzali serię Reflective practice, w omówieniu jej tematyki wymienili m.in. zagadnienia humanizmu $\mathrm{w}$ medycynie i profesjonalizmu pracowników służby zdrowia oraz związanych z tymi kwestiami wyzwańn ${ }^{34}$. Przywołane cytaty potwierdzają te założenia. Tematem przykładu e) jest co prawda pacjent, jednak sposób, w jaki lekarz opisuje jego stan, daleki jest od suchego, rzeczowego tekstu, z jakim czytelnik spotyka się na łamach fachowej prasy medycznej. Przywołując metaforyczny obraz światła i promieni słonecznych, autor opisuje stan pacjentki, która nie odczuwa już bólu i jest $z$ tego powodu szczęśliwa. W przykładzie f) autor snuje refleksję nad sensem pracy lekarza. Pyta, czego lekarz w istocie pragnie, odnosząc się w szczególności do poczucia władzy, jakie daje tytuł doktora. W przykładzie g) z kolei lekarz dzieli się swoimi spostrzeżeniami

30 Patrycja Zurzycka, Teresa Radzik, Medycyna narracyjna..., op. cit., s. 429.

31 Mark Saxena, Lost in translation, „Annals of Internal Medicine” 2009, s. 419.

32 David Alex Stroh, Just playing doctor, „Annals of Internal Medicine” 2009, s. 421 .

${ }^{33}$ Samantha M. Jaglowski, Lovenox hurts, „Annals of Internal Medicine” 2009, s. 585 .

34 David Hatem, Elizabeth A. Rider, Sharing stories..., op. cit., s. 252. 
dotyczącymi sytuacji, w której zmuszony był przyjąć rolę pacjenta, co okazało się dla niego cennym doświadczeniem. Należy podkreślić, iż zarówno tematyka poruszana $\mathrm{w}$ tych wypowiedziach, jak i stosowane przez autorów środki wyrazu, nie znalazłyby się w fachowych publikacjach medycznych. Dlatego też wszystkie prezentowane fragmenty prac można uznać za źródło nowych perspektyw, a także za okazję do podjęcia przez personel medyczny refleksji nad sobą i istotą wykonywanego zawodu.

Zaprezentowane $\mathrm{w}$ niniejszym artykule prace wpisują się $\mathrm{w}$ szersze zmiany zachodzące $w$ praktyce medycznej, tj. $w$ tzw. model wsparcia pacjenta, postulujący włączenie osoby leczonej w proces diagnozy i terapii, oraz tzw. Medycyny 2.0. Nie roszczą sobie one prawa do bycia publikacjami stricte naukowymi, opartymi na wiedzy i badaniach przeprowadzanych na dużych populacjach. Teksty te przynoszą jednak wielorakie korzyści tak pacjentowi, jak i lekarzowi. Pokazują, jakie znaczenie w procesie terapeutycznym ma narracja, wypowiedź osoby leczonej: że może ona być istotnym źródłem informacji medycznej oraz że oferuje nowe perspektywy w komunikacji specjalistycznej. Z punktu widzenia pacjenta tego typu publikacje dowartościowują jego opinię jako osoby leczonej i dają możliwość podzielenia się historią choroby $z$ innymi ludźmi. Może to mieć efekt terapeutyczny dla pacjenta ${ }^{35}$, gdyż, jak wcześniej wspomniano, narracje pozwalają wprowadzić pewien porządek i nadać wartość ludzkiemu doświadczeniu. Według Petera Wilcocka i współautorów, opowieści, „które opisują bezpośrednio doświadczenie, mogą pozytywnie wpłynąć na umiejętność zrozumienia po stronie słuchających poprzez wgląd w pewne ukryte treści dostępne tylko mówiącym, znającym swój własny kontekst funkcjonowania" ${ }^{36}$. Dla lekarza z kolei korzyści z tego typu publikacji również są dwojakie. Te teksty, które przedstawiają relacje lekarzy, umożliwiają pracownikom służby zdrowia refleksję nad zawodem, nad wartościami

${ }^{35}$ Paul Haidet, Debora A. Paterniti, „Building” a history rather than “taking” one: a perspective on information sharing during the medical interview, „Archives of Internal Medicine" 2003, s. 1135.

${ }^{36}$ Por. Peter M. Wilcock, Geraint C.S. Brown, John Bateson, Jonathon Carver, Sheelagh Machin, Using patient stories to inspire quality improvement within the modernisation agency collaborative programmes, "Journal of Clinical Nursing” 2003, s. 422; Pauline Turner, Frances Sheldon, Colin Coles, Brenda Mountford, Richard Hillier, Patricia Radway, Bee Wee, Listening to and learning from the family carer's story: an innovative approach in interprofessional education, "Journal of Interprofessional Care” 2009, s. 394-395. 
i ideałami związanymi $z$ tą profesją ${ }^{37}$, a także mogą wnieść istotny wkład $\mathrm{w}$ ich proces formacyjny ${ }^{38}$. Pewne cechy narracyjne widoczne są także $\mathrm{w}$ interakcjach między specjalistami, np. w komunikacji w zespole terapeutycznym - opowieści są swego rodzaju narzędziem przekazywania wiedzy ${ }^{39}$. Relacje pacjentów mogą stanowić dla personelu medycznego ważne źródło informacji, dotychczas niedoceniane lub w ogóle wyłączone $z$ komunikacji fachowej. Wymagają one też od lekarza wnikliwości, wrażliwości i troski w kontakcie z pacjentem ${ }^{40}$.

Różne perspektywy wyrażane w omówionych publikacjach oraz bogactwo prezentowanej w nich tematyki uzupełniają wiedzę medyczną przedstawianą $\mathrm{w}$ specjalistycznym piśmiennictwie, a także stanowią przyczynek do dyskusji dotyczących zdrowia pacjenta oraz kwestii społecznych i etycznych w szeroko pojętej tematyce medycznej ${ }^{41}$. Włączenie głosu pacjenta do ściśle specjalistycznej wymiany informacji to również znacząca zmiana w ewolucji gatunków medycznych i w samym sposobie przekazywania wiedzy medycznej.

\section{Bibliografia}

Barusch A., Refining the Narrative Turn: When does story-telling become research?, referat wygłoszony na konferencji Gerontological Society of America, 16 listopada 2012, San Diego; http://www.amandabarusch.com [dostęp 27.05.2018].

Bochenek K., Kortko D., Ludzie czy bogowie. 27 rozmów z najstynniejszymi polskimi lekarzami, Agora, Warszawa 2015.

Caiman K.C., Literature in the education of the doctor, „Lancet” 1997, nr 9091, s. 16201622.

Charon R., Narrative Medicine: Attention, Representation, Affiliation, „Narrative” 2005, nr 13, s. 261-270.

Davidoff F., On being a patient, „Annals of Internal Medicine” 1996, nr 124, s. 269-270. Enoch M.D., Case reports (Letter), „British Journal of Psychiatry” 2005, nr 186, 2, s. 169.

${ }^{37}$ Frank Davidoff, On being a patient, „Annals of Internal Medicine” 1996, s. 270.

${ }^{38}$ Barbara Nicholas, Grant Gillett, Doctors' stories, patients' stories: a narrative approach to teaching medical ethics, „Journal of Medical Ethics” 1997, s. 296.

${ }^{39}$ Ibidem.

${ }^{40}$ Kenneth C. Caiman, Literature in the education of the doctor, „Lancet” 1997, s. 1621.

${ }^{41}$ Anne Hudson Jones, Narrative in medical ethics, „British Medical Journal” 1999, s. 254. 
Eysenbach G., Medicine 2.0: social networking, collaboration, participation, apomediation, and openness, „Journal of Medical Internet Research” 2008, nr 10, 3; http://asset.jmir.pub/assets/8eacc4947ad0366ffc293913ea261bf8.pdf [dostęp 8.10.2018].

Floros G.D., Charatsidou I., Lavrentiadis G., A case of PTSD presenting with psychotic symptomatology: a case report, „Cases Journal” 2008, nr 1, 352, s. 1-5; http://www. casesjournal.com/content/1/1/352 [dostęp 3.09.2012].

Goban-Klas T., Media. Od oglądania do wyszukiwania, w: idem (red.), Komunikowanie $w$ ochronie zdrowia - interpersonalne, organizacyjne $i$ medialne, ABC Wolters Kluwer, Warszawa 2004, s. 187-194.

Haidet P., Paterniti D., A „Building” a history rather than "taking”: a one perspective on information sharing during the medical interview, "Archives of Internal Medicine” 2003, nr 163, 10, s. 1134-1140.

Hatem D., Rider E.A., Sharing stories: Narrative medicine in an evidence-based world, „Patient Education and Counselling” 2004, nr 54, s. 251-253.

Hawkins Hunsaker A., Reconstructing Illness: Studies in Pathography, Purdue University Press, West Lafayette 1993.

Hudson J.A., Narrative in medical ethics, „British Medical Journal” 1999, nr 318, s. $253-$ 256.

Hunter K.M., Narrative, literature, and the clinical exercise of practical reason, „The Journal of Medicine and Philosophy" 1996, nr 21, 3, s. 303-320.

Jaglowski S.M., Lovenox, „Annals of Internal Medicine” 2009, nr 151, s. 585-586.

JAMA Instruction for authors 1; http://jama.jamanetwork.com/ public/instructionsForAuthors.aspx\#CategoriesofArticles [dostęp 27.09.2018].

JAMA Instruction for authors 2; http://archpedi.jamanetwork. com/public/instructionsForAuthors.aspx\#SecCategoriesofArticles [dostęp 27.09.2018].

Karkowski T.A., Karkowska D., Skoczylas P., Medycyna personalizowana a medycyna narracyjna, w: A. Jackiewicz, G. Piotrowski, Ł. Sułkowski (red.), Ekonomiczne, medyczne i prawne aspekty zdrowia publicznego, seria "Przedsiębiorczość i Zarządzanie”, t. XVII, z. 12, cz. III, Wydawnictwo Społecznej Akademii Nauk, Łódź 2016, s. $85-96$.

Kay A., Będzie bolało. Sekretny dziennik młodego lekarza, przeł. K. Dudzik, Wydawnictwo Insignis, Kraków 2018.

Kearney R., On stories, Routledge, New York 2002.

Labov W., Waletzky J., Narrative analysis: Oral versions of personal experience, w: J. Helm (red.), Essays on the verbal and visual arts, University of Washington Press, Seattle 1967, s. 12-44.

Mehl-Madrona L., The nature of narrative medicine, „The Permanente Journal” 2007, nr 11, 3, s. 83-87.

Murawska M., The many narrative faces of medical case reports, „Poznań Studies in Contemporary Linguistics" 2012, nr 48, 1, s. 55-75. 
Nicholas B., Gillett G., Doctors' stories, patients' stories: a narrative approach to teaching medical ethics, „Journal of Medical Ethics” 1997, nr 23, s. 295-299.

Nissen T., Wynn R., The clinical case report: a review of its merits and limitations, „BMC Research Notes" 2014, nr 7, 264, s.1-7; http://www.biomedcentral.com/17560500/7/264 [dostęp 1.02.2015].

Pasierski T., Choroba jako opowieść, „Medycyna po Dyplomie” 2008, nr 17, 9, s. 68-71. Prince G., Narratology. The form and functioning of narrative, Mouton, Berlin 1982.

Reis S., Hermoni D., Livingstone P., Borkan J., Integrated narrative and evidence based case report: Case report of paroxysmal atrial fibrillation and anticoagulation, „British Medical Journal" 2002, nr 325, s. 1018-1020.

Reszka P., Mali bogowie. O znieczulicy polskich lekarzy, Wydawnictwo Czerwone i Czarne, Warszawa 2017.

Salim S., Ganeshram P., Patel A.D., Kumar A.A., Vemuri D., Jeyachandran V., Rajamanickam D., Shantha G.P.S., Unilateral hemothorax in a 46 year old South Indian male due to a giant arteriovenous hemodialysis fistula: a case report, „Cases Journal" 2008, nr 1, 225, s. 1-4; http://www.casesjournal.com/content/1/1/225 [dostęp 3.09.2012].

Saxena M., Lost in translation, „Annals of Internal Medicine” 2009, nr 150, s. 419-420. Stewart M., Bell Brown J., Weston W., McWilliam C.L., Freeman T.R., Exploring Health, Disease and the Illness Experience, w: J. Bell Brown, T. Thornton, M. Stewart (red.), Challenges and Solutions: Narratives of Patient-centred Care, Radcliffe Publishing, London 2012.

Stroh D.A., Just playing doctor, „Annals of Internal Medicine” 2009, nr 150, s. 421-422. Turner P., Sheldon F., Coles C., Mountford B., Hillier R., Radway P., Wee B., Listening to and learning from the family carer's story: an innovative approach in interprofessional education, „Journal of Interprofessional Care” 2009, nr 14, 4, s. 387-395.

Wilcock P.M., Brown G.C.S., Bateson J., Carver J., Machin S., Using patient stories to inspire quality improvement within the modernisation agency collaborative programmes, „Journal of Clinical Nursing” 2003, nr 12, s. 422-430.

Zabielska M., Żelazowska M., From breathing difficulty to dyspnea: a translation process from the patient's story to the doctor's report in interactive medical case reports, „Communication \& Medicine” 2017, nr 14, 1, s. 69-81.

Zabielska M., Żelazowska M., Narracyjny charakter medycznego opisu przypadku a jego spójność, w: M. Górnicz, M. Kornacka (red.), Spójność tekstu specjalistycznego (2), Wydawnictwo Naukowe Instytutu Komunikacji Specjalistycznej i Interkulturowej Uniwersytetu Warszawskiego, Warszawa 2015, s. 125-134; http://www.sn.iksi.uw.edu.pl/documents/7732735/0/SN+34+M_Górnicz+M Kornacka+Spójność\%20tekstu+specjalistycznego+2.pdf [dostęp 16.10.2018]. Zurzycka P., Radzik T., Medycyna narracyjna - zarys problematyki, „Problemy Pielęgniarstwa” 2015, nr 23(3), s. 428-432. 


\section{"I remember it happened to me on a Saturday morning, around 10". Professional medical publications based on patients' and doctors' narratives}

The aim of this paper is to demonstrate a new publication type based on narratives and the backdrop for its development, as well as its importance in the context of both medical education and doctors' formative process. First, the significance of narrative in human life and the development of narrative studies in the humanities will be discussed. A narrative character of the very profession of medicine will be emphasised as well. Finally, fragments of particular narrative-based publications will be presented, especially in the context of the subjective presentation of patient's or doctor's experience, which will be aimed at illustrating how this complement of the perspective may be used in medical education as well as in doctor's professional development, e.g. through emphasising the importance of the patient's role.

KEY WORDS: narrative medicine, specialised medical discourse, patient

\section{A B S T R A K T}

\section{„Pamiętam, zdarzyło się to w sobotę rano, około 10".} Fachowe publikacje medyczne oparte na relacjach pacjentów i lekarzy

Celem niniejszego artykułu było zaprezentowanie nowego typu publikacji w międzynarodowych fachowych czasopismach medycznych, w których obierany jest punkt widzenia zarówno pacjenta, jak i innych uczestników procesu diagnozowania i leczenia, przekazywany w formie osobistych opowieści. Autorki pokazały tło ich powstania, tj. wagę samej relacji w życiu człowieka oraz jej znaczenie dla zawodowego rozwoju lekarza, a także rozwój badań narracyjnych w naukach humanistycznych. W artykule został również podkreślony narracyjny charakter samej profesji medycyny oraz zaprezentowane zostały fragmenty konkretnych publikacji opartych na narracjach, w szczególności w kontekście subiektywnego przedstawienia doświadczenia pacjenta i/lub lekarza.

SŁOWA KLUCZOWE: medycyna narracyjna, fachowy dyskurs medyczny, pacjent 
Anna Kuzio

Uniwersytet Zielonogórski

\section{Teoria grzeczności a konstruowanie spójności w narracjach lekarzy i pacjentów. Studium diagnozy w polskim dyskursie medycznym}

\section{Wprowadzenie}

Najważniejszą funkcją języka jest bez wątpienia komunikacja, zwłaszcza wtedy, gdy rozmówcami są lekarze i pacjenci. Pacjenci doświadczający trudów choroby i wymagający specjalistycznej pomocy, która przyniesie im ulgę w cierpieniach fizycznych i psychicznych, oczekują od lekarzy „dobrego zachowania” czy raczej „uprzejmości”. O uprzejmym obcowaniu z ludźmi pisze Gino Eelen ${ }^{1}$, przywołując teorię grzeczności autorstwa Penelope Brown i Stephena Levinsona ${ }^{2}$, wykorzystywaną w licznych badaniach nad dyskursem ${ }^{3}$. Wielu badaczy zajmowało się komunikacją w kontekście medycznym, także z perspektywy dyskursywnej i pod kątem analizy konwersacji, uwzględniając właśnie ów aspekt uprzejmości ${ }^{4}$.

Również w polskich badaniach nad komunikacją medyczną znajdziemy opisy interakcji lekarz-pacjent ${ }^{5}$, w których z różnych perspektyw

${ }^{1}$ Gino Eelen, A Critique of Politeness Theories, Manchester 2001.

2 Penelope Brown, Stephen Levinson, Politeness: Some Universals in Language Usage, Cambridge 1987.

${ }^{3}$ Minna Nevala, Accessing politeness axes: forms of address and terms of reference in early English correspondence, "Journal of Pragmatics” 2004, s. 2125-2160; Massimo Bazzocchi, Doctor-patient communication in radiology: a great opportunity for future radiology, „La radiologia medica” 2012, s. 339-353.

${ }^{4}$ Ruth Wodak, Critical discourse analysis and doctor-patients' interaction, w: Britt-Louise Gunnarsson, Per Linell, Bengt Nordberg (red.), The Construction of Professional Discourse, London 1997, s. 173-200.

${ }^{5}$ Maria Nowina-Konopka, Komunikacja lekarz-pacjent. Teoria i praktyka, Kraków 2016; Anna Zembala, Modele komunikacyjne w relacjach lekarz-pacjent, „Zeszyty Naukowe 
analizowane są wielorakie aspekty tej relacji. Uwzględniające pragmatykę dyskursu badania nad interakcjami między lekarzami a pacjentami, takie jak te przedstawione $\mathrm{w}$ niniejszym artykule, wzbogacają dotychczasową literaturę na temat komunikacji medycznej w Polsce, a także pozwalają przybliżyć dyskursywną i pragmatyczną specyfikę tej komunikacji. Zgromadzony na potrzeby artykułu materiał to zapisy rozmów polskich lekarzy i pacjentów, odbywających się w wybranych placówkach medycznych na terenie Polski. Dane były zbierane w prywatnych klinikach w województwie dolnośląskim, w okresie od 10.03.2017 do 30.06.2018 roku. Należy dodać, że wszyscy lekarze biorący udział w badaniu przeszli specjalne szkolenie mające na celu poprawę ich umiejętności komunikacyjnych. W analizie interakcji lekarzy i pacjentów, prowadzonej z perspektywy pragmatyki dyskursu, uwzględniam obserwacje poczynione przez Susan Marie Barone ${ }^{6}$.

Jednym z warunków osiągnięcia kompetencji komunikacyjnej przez pracowników opieki medycznej - niezależnie od języka, jakim się porozumiewają - jest znajomość pragmalingwistyki i socjolingwistyki komunikacji medycznej. W komunikacji lekarz-pacjent wyróżnia się zwykle trzy części składowe: wywiad (lub diagnozę), leczenie i kontrolę ${ }^{7}$. Badanie komunikacji w medycynie pod kątem uprzejmości, opisane w tym artykule, ograniczam do diagnozy jako najbardziej znaczącego aspektu interakcji między lekarzem i pacjentem, która w pełni opiera się na rozmowie. Przedstawiam próbę analizy kontekstualnie wyrażanych przekonań lekarzy i pacjentów, lingwistycznych wzorców stosowanych w rozmowach oraz pragmatycznych zachowań podejmowanych przez ich uczestników. Szczególną uwagę zwracam na wiek i płeć pacjentów oraz na związek tych zmiennych ze strategiami uprzejmości stosowanymi przez lekarzy.

W kilku znanych mi badaniach poddawano analizie poziom uprzejmości stron interakcji w szpitalach, z uwzględnieniem wybranych aspektów,

Towarzystwa Doktorantów UJ Nauki Ścisłe" 2015, s. 35-50; Karolina Stefaniak, Wtadza $i$ tożsamość w komunikacji lekarz-pacjent, Wrocław 2011; Antonina Ostrowska (red.), Jak rozmawiać $z$ pacjentem? Anatomia komunikacji w relacji w praktyce lekarskiej, Warszawa 2017.

${ }^{6}$ Susan Marie Barone, Seeking narrative coherence: Doctors' elicitations and patients' narratives in medical encounters, praca doktorska, 2012; https://core.ac.uk/download/ pdf/41337614.pdf [dostęp 13.10.2019].

${ }^{7}$ Ruth Wodak, Critical discourse analysis..., op. cit., s. 173-200. 
m.in. tego, w jaki sposób kulturowo i instytucjonalnie uwarunkowane postawy pacjentów i lekarzy względem siebie wchodzą w kolizję już na etapie przywitania w kategoriach „zachowania twarzy” (pojęcie to wyjaśnię później) i uprzejmości ${ }^{8}$ Z mojego rozeznania wynika, że prawie w ogóle nie ma badań porównawczych (międzynarodowych) na ten temat.

Niniejszy artykuł jest osadzony w kontekście medycyny narracyjnej ${ }^{9}$. Chciałabym pokazać, jak narracje tworzone przez lekarzy i pacjentów wpływają na kształtowanie procesu komunikacji medycznej, a zwłaszcza - w jaki sposób pacjenci wykorzystują środki językowe wskazujące na ich sprawstwo przy opisywaniu swojego stanu zdrowia. Analiza związku między wypowiedziami lekarzy a narracjami pacjentów - zrozumienie tej relacji - ma swój wymiar praktyczny i przekłada się na większą skuteczność opieki medycznej. Jak podkreśla John W. Creswell ${ }^{10}$, stworzenie przestrzeni dla narracji prowadzi do większej satysfakcji pacjentów i trafniejszych diagnoz. Zainspirowana publikacjami dotyczącymi medycyny narracyjnej przyjmuję założenie, że w interakcji pacjenta z lekarzem narracja może być obecna jawnie lub może być ukryta i że w mniejszym lub większym stopniu jest ona inicjowana przez pracownika służby zdrowia ${ }^{11}$.

Medycyna narracyjna to koncepcja stworzona przez Ritę Charon. Narracja jest w tym ujęciu rozumiana jako opowieść wyrażona słowami, gestami, milczeniem, szkicem, obrazem i innymi fizycznymi przejawami, które pokazują, że „dowolne zjawisko, aby było rozumiane, musi być umieszczone $\mathrm{w}$ kontekście" 12 . Badanie przedstawione $\mathrm{w}$ tym artykule opiera się na tej samej przesłance, to znaczy zakładam, że pacjent tworzy narrację, a zadaniem pracownika służby zdrowia jest zachęcanie go do jej wyrażenia, stwarzanie przestrzeni i wyrażanie gotowości do uważnego, empatycznego słuchania. Podobną myśl wyraził Irving Zola, pisząc

8 Sage Lambert Graham, Hospitalk: Politeness and hierarchical structures in interdisciplinary discharge rounds, „Journal of Politeness Research. Language, Behaviour, Culture" 2009, s. 11-31.

9 Rita Charon, Narrative Medicine: Honoring the Stories of Illness, New York 2006.

10 John W. Creswell, Narrative, pain, and suffering, „New England Journal of Medicine" 2005, s. 1637.

11 Rita Charon, Narrative Medicine..., op. cit.

12 Ibidem. 
o relacji lekarza z pacjentem jako o „procesie, w którym jednostka decyduje, że zestaw cielesnych bolączek, które określa jako objawy, zasługuje na uwagę specjalisty" ${ }^{13}$.

W literaturze z zakresu komunikacji w opiece medycznej podkreśla się, że język jest współkonstruowany - komunikat nadawany przez jednego rozmówcę staje się komunikatem odbieranym przez drugiego ${ }^{14}$. W ciągu ostatnich trzydziestu lat widoczny był dynamiczny rozwój koncepcji łączących pojęcia z zakresu lingwistyki stosowanej i komunikacji w służbie zdrowia $^{15}$. Takie interdyscyplinarne podejście $\mathrm{w}$ połączeniu $\mathrm{z}$ koncepcją medycyny narracyjnej Rity Charon pozwoliło stworzyć wartościowy model opisu interakcji lekarz-pacjent. Zastosowana w przedstawianym tu badaniu metodologia obejmuje zatem podejście socjolingwistyczne $\mathrm{w}$ analizie werbalnej interakcji międzyludzkiej połączone $z$ klinicznym podejściem medycyny narracyjnej, stwarzając w ten sposób nową perspektywę badawczą w obszarze wspólnych dla obu dziedzin zainteresowań.

Wykorzystując analizę dyskursu, w artykule koncentruję się na wpływie formy pytań na role lekarza i pacjenta we współkonstruowaniu narracji chorego. Podobnie jak w zwykłej codziennej komunikacji, pacjenci i lekarze wykorzystują opowieści, aby wyrazić i zrozumieć wydarzenia $z$ życia pacjenta oraz ich wpływ na stan jego zdrowia ${ }^{16}$. Ponadto szczególną wagę przywiązuję do tego, jak konstruowana przez pacjentów spójność narracyjna, ogólne „rozumienie sytuacji” ${ }^{17}$, wpływa na język interakcji i sposób, w jaki pacjenci przedstawiają swoją tożsamość.

13 Irving Zola, Pathways to the doctor: from person to patient, „Social Science and Medicine" 1973, s. 677-689.

14 Susan Eggly, Health Communication, New York 2002.

15 Christopher N. Candlin, Sally Candlin, Health care communication: a problematic site for applied linguistics research, „Annual Review of Applied Linguistics” 2003, s. $134-154$.

${ }^{16}$ Elinor Ochs, Lisa Capps, Living Narrative: Creating Lives in Everyday Storytelling, Cambridge 2001.

17 Deborah Tannen, Cynthia Wallat, Interactive frames and knowledge schemas in interaction: Examples from a medical interview, w: D. Tannen (red.), Framing in Discourse, New York 1993, s. 57-76. 


\section{Podstawy teoretyczne}

Komunikacja między lekarzem a pacjentem stanowi przykład mowy w kontekście instytucjonalnym - ściśle wiąże się z instytucją, w której zachodzi, i z obowiązującymi w niej warunkami. Te instytucje i organizacje - w przypadku komunikacji medycznej są to szpitale, przychodnie, prywatne gabinety - determinują kontekst społeczny komunikacji opisywany przez Normana Fairclougha ${ }^{18}$. Według niego wszelkie postaci dyskursu instytucjonalnego są kształtowane przez istytucje, a te z kolei organizowane są przez bardziej ogólne relacje dotyczacce władzy. Joanna Thornborrow ${ }^{19}$ podaje, że dyskurs instytucjonalny charakteryzuje się następującymi cechami: jest nakierowany na cel, role jego uczestników są zróżnicowane, $z$ góry przypisane oraz asymetryczne.

Podczas spotkania z pacjentem lekarz może pozyskać niezbędne informacje, aby postawić diagnozę i udzielić mu pomocy lub chociaż podjąć taką próbę. To nakierowanie na cel determinuje większość aspektów interakcji zachodzących między lekarzem i pacjentem. Co więcej, badania wskazują, że to zwykle lekarze inicjują oraz kończą proces zbierania wywiadu ${ }^{20}$; pacjenci prawie zawsze starają się uzyskać możliwie jak najwięcej informacji, a lekarzom zdarza się (z różnych względów) pewne informacje pomijać $\mathrm{w}$ rozmowie $\mathrm{z}$ pacjentem ${ }^{21}$. Ta zdolność kontrolowania informacji przez lekarza jest źródłem fundamentalnej asymetrii w omawianej tu relacji. Według Johna Heritage'a ${ }^{22}$ uczestnicy instytucjonalnych kontaktów wykorzystują wiele narzędzi językowych i interakcyjnych. Ich uwzględnienie pozwala tak oto scharakteryzować relacje instytucjonalne: uczestnicy relacji mają przypisane określone role, dana instytucja narzuca ludziom pewne ograniczenia, w relacjach w obrębie danej instytucji stosuje się specyficzne procedury i określone sposoby konstruowania wypowiedzi ( $z$ wykorzystaniem charakterystycznych struktur

18 Norman Fairclough, Language and Power, London 1989.

19 Joanna Thornborrow, Power Talk: Language and Interaction in Institutional Discourse, Harlow 2002.

20 Jiří Beran, Doctor-patient communication: Part I - Introduction, Prague 1999.

${ }^{21}$ Howard Waitzkin, Information giving in medical care, "Journal of Health and Social Behavior” 1985, s. 81-101.

${ }^{22}$ John Heritage, Conversation analysis and institutional talk, w: D. Silverman (red.), Qualitative Research: Theory, Method and Practice, London 1977, s. 161-182. 
językowych). Wymienione cechy są dodatkowo uzupełniane przez takie elementy, jak: sekwencyjność (komunikatów i działań), dobór leksyki, a także asymetryczność relacji. Badając relacje lekarzy i pacjentów, Malcolm Coulthard i Margaret Ashby ${ }^{23}$ zauważyli powtarzalność inicjowanych przez lekarza wymian zdań z pacjentem w ramach interakcji diagnostycznych. Według nich, jeśli pacjent próbuje inicjować konwersację, lekarz nie czuje się zobowiązany do udzielenia odpowiedzi.

Należy także zwrócić uwagę na fakt, że komunikację między lekarzem a pacjentem cechuje wysoki poziom sformalizowania i dystansu, co szczególnie uwidacznia się w kontekście zastosowania pojęcia grzeczności. Grzeczność, dostrzegalna w warunkach dystansu społecznego lub intymności, to sposób, w jaki jednostki dają wyraz świadomości „twarzy” innej osoby, tzn. jej publicznego wizerunku ${ }^{24}$. Badacze proponowali różne maksymy grzeczności ${ }^{25}$. Z szeroką akceptacją spotkały się takie określenia zasugerowane przez Geoffreya Leecha ${ }^{26}$, jak „takt”, „szczodrość”, „aprobata”, „skromność, „zgoda”, „sympatia”. Leech, zainspirowany maksymami konwersacyjnymi Paula Grice’a, rozwinął wcześniejsze ujęcia grzeczności, wskazując czynniki, które kierują konwersacją i które ją ograniczają. Ograniczenia rozpoznane przez Leecha dotyczą głównie tego, że maksymy nie odnoszą się do ekspresyjnych aspektów języka ${ }^{27}$ ani do sposobu, w jaki język jest wykorzystywany do rozwiązywania problemów $\mathrm{w}$ relacjach interpersonalnych ${ }^{28}$.

Podstawowym elementem całościowej teorii grzeczności sformułowanej przez Penelope Brown i Stephena Levinsona ${ }^{29}$ jest zarządzanie relacjami

${ }^{23}$ Malcolm Coulthard, Margaret Ashby, A linguistic description of doctorpatient interviews, w: M. Wadsworth, D. Robinson (red.), Studies in everyday medical life, London 1976.

${ }^{24}$ Erving Goffman, Interaction Ritual: Essays on Face-to-Face Behavior, New York 1967; Penelope Brown, Stephen Levinson, Politeness..., op. cit.; Jenny Thomas, Crosscultural pragmatics failure, „Applied Linguistics” 1995, s. 91-112.

${ }^{25}$ Robin T. Lakoff, The logic of Politeness; or, minding your p's and q's, Chicago 1973; Geoffrey Leech, Principles of Pragmatics, London 1983; Bruce Fraser, Perspectives on politeness, „Journal of Pragmatics” 1990, s. 219-236.

${ }^{26}$ Bruce Fraser, Perspectives on politeness, „Journal of Pragmatics” 1990, s. 219-236.

${ }^{27}$ Judith Spiers, The use of facework and politeness theory, „Qualitative Health Research" 1998, s. 25-47.

${ }^{28}$ Maria Sifianou, Politeness phenomena in England and Greece, Oxford 1992.

${ }^{29}$ Penelope Brown, Stephen Levinson, Politeness..., op. cit. 
nakierowanymi na kooperację przez uwzględnianie „pozytywnej” i „negatywnej twarzy”. Teoria grzeczności Brown i Levinsona opiera się na wyrażonej przez Ervinga Goffmana ${ }^{30}$ obserwacji, że jednostki, które wchodzą w interakcje, starają się maksymalizować zasób zwany „pożądanym wizerunkiem publicznym"31. Według Judith Spiers ${ }^{32}$ należy pamiętać, że choć „twarz” (czyli publiczny wizerunek) może być kojarzona z pojęciem self, to analogia ta ma ograniczoną przydatność, gdyż „twarz” nie odnosi się do inherentnych właściwości osoby, lecz jest demonstrowana w interakcjach $z$ innymi. Brown i Levinson ${ }^{33}$ dodają $w$ uzupełnieniu, że potrzeba tworzenia i utrzymywania wizerunku nie działa zwykle na poziomie świadomości. Ponieważ tworzenie wizerunku może zachodzić w okolicznościach określanych jako „wzajemna wrażliwość” ${ }^{4}$, wydaje się, że w dobrze pojętym interesie wszystkich uczestników interakcji jest wzajemna dbałość o zaspokajanie potrzeb dotyczących „twarzy”. Pozytywny wizerunek wzmacnia się wtedy, gdy przyjmujemy i okazujemy czułość, solidarność, wyrażamy pozytywne oceny, gdy doceniamy indywidualność drugiego człowieka i okazujemy mu zrozumienie ${ }^{35}$. Negatywny wizerunek jest konsekwencją narzucania innym własnej potrzeby autonomii, wyznaczania terytorium i niezależności w myśli i w działaniu. Każda wypowiedź może się okazać zagrażająca dla wizerunku, stać się „aktem zagrażającym twarzy" (ang. face threatening act; w skrócie FTA) ${ }^{36}$. Brown i Levinson ${ }^{37}$ wyróżniają pięć następujących strategii grzeczności wykorzystywanych w ramach budowania wizerunku:

1) bezpośrednią - zwięzłe wypowiedzi (zgodnie z maksymą ilości Paula Grice'a), które nie zawierają żadnych wyrażeń pośrednich, np. polecenie „oddychaj głęboko”;

2) pozytywną uprzejmość - wypowiedzi chroniące i okazujące uznanie wobec „pozytywnej twarzy” rozmówcy;

30 Erving Goffman, Interaction Ritual..., op. cit.

31 Steven Pinker, Indirect speech, politeness, deniability, and relationship negotiation: Comment on Marina Terkourafi's “The Puzzle of Indirect Speech”, „Journal of Pragmatics" 2011, s. 2866-2868.

32 Judith Spiers, The use of facework..., op. cit., s. 25-47.

33 Penelope Brown, Stephen Levinson, Politeness..., op. cit., s. 58.

34 Ibidem, s. 61.

35 Judith Spiers, The use of facework..., op. cit., s. 25-47.

36 Penelope Brown, Stephen Levinson, Politeness..., op. cit., s. 61.

37 Ibidem, s. 61. 
3) negatywną uprzejmość - wypowiedzi nastawione na utrzymanie (przez mówiącego lub słuchacza) „negatywnej twarzy”, to jest zachowanie autonomii, unikanie poleceń i utrzymywanie odpowiedniego dystansu społecznego;

4) pośrednią - wypowiedzi, które nie ujawniają wprost intencji interlokucyjnej, ale w celu zachowania twarzy i umożliwienia słuchaczowi udzielenia odpowiedzi lub odmowy tejże, intencja jest tylko sygnalizowana;

5) odmowę podjęcia FTA - występująca, kiedy jednostka postrzega akt mowy jako nazbyt zagrażający, wobec czego się przed nim powstrzymuje.

Brown i Levinson dodają, że na tym mikropoziomie słowa odnoszące się do „twarzy” określają jako komunikaty warunkujące wydajność wypowiedzi ${ }^{38}$. Nie wskazują wyraźnie, który aspekt mowy - lokucyjny czy illokucyjny - jest brany pod uwagę. Wydaje się jednak, że wymienione komunikaty zwykle są intencjonalne. Ta interpretacja znajduje dodatkowe uzasadnienie w szczegółowych opisach superstrategii i mechanizmów stosowanych w tych komunikatach.

Istnieje wiele zasad kontrolujących używanie mowy, $z$ których nawet jej kompetentni użytkownicy nie muszą zdawać sobie sprawy. Pacjenci są obecnie często traktowani jako konsumenci mający określone oczekiwania wobec usługodawców, takich jak pracownicy służby zdrowia. Co więcej, pacjenci często są zachęcani do wyrażania swojego zdania i podejmowania decyzji dotyczących przebiegu leczenia. Te czynniki przyczyniają się do podwyższania statusu pacjenta, jednak równolegle do nich działa wiele innych uwarunkowań, które ograniczają możliwości angażowania się chorego w proces decyzyjny. Można wśród nich wymienić lęk, istniejące oczekiwania dotyczące norm społecznych, emocjonalne i fizjologiczne problemy wpływające na poczucie kontroli, a także niższy status wynikający z bycia laikiem. Z perspektywy sekwencyjności jako cechy interakcji instytucjonalnej kooperacja wymaga utrzymywania przyjaznych relacji. Także w odniesieniu do komunikacji między lekarzem a pacjentem są one niezwykle ważne ${ }^{39}$, a naruszanie norm kontekstualnych

38 Ibidem, s. 58.

39 Piyush Ranjan, Archana Kumari, Avinash Chakrawarty, How can Doctors Improve their Communication Skills?, "Journal of Clinical and Diagnostic Research: JCDR" 2015, s. JE01-JE4. 
poważnie temu zagraża. Teoria grzeczności i „twarzy” Brown i Levinsona stanowi użyteczne narzędzie do analizowania lingwistycznych strategii wykorzystywanych w celu utrzymania dobrej kooperacji i zarządzania aktami „zagrażającymi twarzy”. Wziąwszy pod uwagę wymienione aspekty teoretyczne, w niniejszym artykule stawiam następujące pytanie badawcze: „Czy wiek i płeć pacjentów mają wpływ na strategie grzeczności stosowane przez lekarzy?”.

Warto podkreślić, że kategoria grzeczności może pomóc w tworzeniu spójności narracyjnej w ramach podejścia klinicznego realizowanego w postaci medycyny narracyjnej. Medycyna narracyjna powstała na pograniczu medycyny i literaturoznawstwa $\mathrm{i}$ jest $\mathrm{w}$ związku $\mathrm{z}$ tym ugruntowana $\mathrm{w}$ teorii narracji. W medycynie narracyjnej próbuje się postrzegać ludzi jako jednostki, a nie jako aglomeraty objawów i nośniki choroby. Ten model opieki nad pacjentem stawia sobie za cel zmianę schematu medycznego wywiadu skoncentrowanego na klinicyście zbierającym dane, budowanie porozumienia, edukowanie i inspirowanie pacjenta. Niemniej jednak zarówno ten, jak i inne modele skoncentrowane na pacjencie nie cieszą się szczególnym powodzeniem w medycynie. Ani formularz w formie drzewa decyzyjnego, ani modele Byrne'a i Longa ${ }^{40}$ nie zawierają opisu „udanego spotkania” lekarza i pacjenta, medycyna narracyjna natomiast stawia je w centrum uwagi i dostrzega zarówno role obu stron interakcji, jak i nakładane na nie wymagania instytucjonalne.

W prezentowanym badaniu skupiam się na ujęciu medycyny narracyjnej jako skoncentrowanym na pacjencie modelu komunikacji, w którym podkreśla się znaczenie interakcji między lekarzem a pacjentem. Relacja jest warunkiem uzyskania od pacjenta jego narracji poprzez stworzenie odpowiedniej przestrzeni dla tej opowieści. Szczególną uwagę zwraca się na słowa lekarza, które stwarzają pacjentowi taką przestrzeń dla jego wypowiedzi, współkonstruują jego narrację. Tak rozumiana medycyna narracyjna „uzupełnia praktykę medyczną kompetencją narracyjną i charakteryzuje się rozumieniem wysoce złożonych sytuacji narracyjnych rozgrywających się między lekarzami, pacjentami, współpracownikami i szerszą społecznością" ${ }^{41}$, ze szczególnym uwzględnieniem narracji pacjentów. Jednak tę narracyjną kompetencję podważa sama natura narracji

40 Patrick S. Byrne, Barrier E.L. Long, Doctors talking to patients: a study of the verbal behaviours of doctors in the consultation, London 1976.

41 Rita Charon, Narrative medicine..., op. cit. 
dotyczących choroby, charakteryzujących się linearnością i spójnością. Charon ${ }^{42}$ przedstawia wprawdzie medycynę narracyjną jako próbę udzielenia głosu pacjentom i ich doświadczeniom, jednak przywoływane przez nią prawdziwe opowieści pacjentów są mocno ograniczone. Przedstawiane są raczej tak, jak zrozumiał je lekarz, umieszczane w równoległej dokumentacji, w niemedycznych zapisach tworzonych przez lekarzy po to, aby mogli sami dla siebie uporządkować opowieści pacjentów.

Wiele cytowanych w tym badaniu narracji dotyczących różnych chorób zrodziło się $\mathrm{w}$ spontanicznych interakcjach pacjentów $\mathrm{z}$ lekarzami. Niektóre $z$ tych opowieści mogą wydawać się mniej spójne, dlatego konieczne było korzystanie $z$ dodatkowych ram analizy narracji, aby uzyskać pełniejsze rozumienie opowieści pacjenta w określonym kontekście.

Zwykle, gdy korzysta się z kanonicznych narzędzi analizy narracji, spójność narracji jest uważana za swego rodzaju miarę władania językiem przez mówiącego i jego predyspozycji emocjonalnych oraz umysłowych. Według Larsa-Christera Hydéna i Jensa Brockmeiera ${ }^{43}$ narracje o chorobie można opisać jako „niezdecydowane, fragmentaryczne i wadliwe”.

Wyniki przedstawione w tym artykule pokazują, że zakres spójności obserwowanej w spotkaniach lekarzy z pacjentami dotyczy także chorób mniej poważnych, przewlekłych, niezagrażających bezpośrednio życiu. W takim przypadku brak spójności może stanowić element opowieści pacjenta. Okazuje się także, że stosowanie strategii grzeczności może przyczyniać się do osiągnięcia pożądanego stopnia spójności w trakcie konstruowania różnych narracji.

\section{Metodologia badania}

W prezentowanym badaniu uwzględniono płeć i wiek pacjentów, wykorzystano wybrane fragmenty ich interakcji z lekarzem, a także zapisy obserwacji pacjenta. Arkusz obserwacyjny został skonstruowany w taki sposób, aby dzielił pacjentów na grupy w zależności od płci i wieku na pacjentów młodszych i starszych niż lekarz. Ponadto, po uzyskaniu

${ }^{42}$ Rita Charon, The Principles and Practice of Narrative Medicine, New York 2017; Rita Charon, Narrative Medicine: Attention, Representation, Affiliation, „Narrative” 2005, s. 261-270.

${ }^{43}$ Lars-Christer Hydén, Jens Brockmeier, Health, Illness, and Culture: Broken Narratives, London 2008, s. 2. 
zgody uczestników na udział w badaniu, rozmowy lekarza z pacjentami były rejestrowane i zapisywane. W trosce o zapewnienie pacjentom anonimowości, obserwatorka nie pytała ich o imię i nazwisko. Następnie, zgodnie $z$ tezami teorii grzeczności Brown i Levinsona klasyfikowane były stosowane przez lekarzy strategie. Badaczka zadawała też lekarzom kilka pytań, aby określić, jak oceniają oni rejestrowaną interakcję z pacjentem. Uczestnikami badania było pięćdziesięcioro pacjentów poradni (dwudziestu pięciu mężczyzn, z czego trzynastu było młodszych od lekarza, a dwunastu starszych od niego, oraz dwadzieścia pięć kobiet, z czego dwanaście młodszych, a trzynaście starszych od lekarza). Lekarze uczestniczący w badaniu mieli od dziesięciu do dwudziestu lat doświadczenia klinicznego.

Narracje pacjentów są w niniejszym badaniu postrzegane jako wyraz radzenia sobie $z$ chorobą. Empatia ze strony lekarza może przyjmować różne formy, a porozumienie między lekarzem i pacjentem pomaga wypracować wspólne dla obu stron znaczenia ${ }^{44}$ i może dostarczać ważnych analitycznych wskazówek ${ }^{45}$. Kompetencja narracyjna w ujęciu Rity Charon przyczynia się do zwiększania empatii lekarza wobec pacjenta i może wyrażać się także w stosowaniu strategii grzczności, nawet jeśli nie jest to otwarcie artykułowane. Lekarz posiadający kompetencję narracyjną może trafniej oceniać, co $\mathrm{w}$ opowieści pacjenta ma z punktu widzenia choroby znaczenie, a co nie ${ }^{46}$. Narracja pacjenta jest dla lekarza kluczem do zrozumienia, w jaki sposób fakty natury medycznej oddziałują na życie pacjenta.

\section{Wyniki badania}

Rycina 1. przedstawia stosowane wobec czterech kategorii - wyodrębnionych ze względu na płeć i wiek - pacjentów strategie grzeczności (słupki obrazują liczbę zaobserwowanych przypadków użycia przez uczestników badania poszczególnych strategii).

Widać, że strategia bezpośrednia występowała najczęściej. Na przykład lekarz powiedział do 29-letniej pacjentki: „Nie oddychać przez chwilę!”, a do 46-letniego pacjenta zwrócił się słowami: „Weź głęboki wdech i nie

${ }^{44}$ Catherine Kohler Riessman, Narrative Methods for the Human Sciences, Thousand Oaks 2008.

${ }^{45}$ Trisha Greenhalgh, Brian Hurwitz, Ethics and narrative, „British Medical Journal” 1999, s. 48-50.

${ }^{46}$ Rita Charon, Narrative Medicine..., op. cit. 


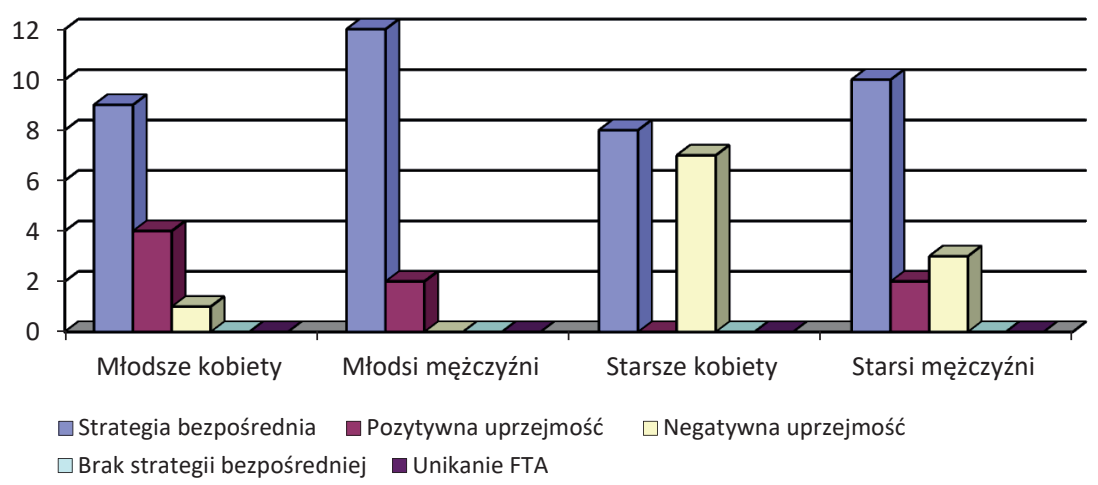

Rycina 1. Wykorzystywane strategie grzeczności (opracowanie własne)

oddychaj”. Przykłady te pokazują, że przekaz lekarza nie jest zróżnicowany ze względu na płeć pacjenta - lekarz wybiera bezpośrednią komunikację w kontaktach zarówno z mężczyznami, jak i z kobietami. Mniejsze jest prawdopodobieństwo zastosowania tej strategii przez lekarza w kontakcie ze starszymi pacjentami (mężczyznami i kobietami). Natomiast największą liczbę zastosowań strategii bezpośredniej zaobserwowano w kontaktach lekarek i lekarzy ze starszymi od nich pacjentami płci męskiej. Jest to zaskakujące, gdyż w rozmowach ze starszymi ludźmi oczekuje się okazywania szacunku i stosowania mowy zależnej, ale tutaj widoczne są przypadki skracania dystansu i stosowania bezpośrednich poleceń.

Kolejna strategia to pozytywna uprzejmość, zwykle stosowana wobec pacjentek młodszych od lekarza. Przejawia się ona między innymi w wykorzystywaniu takich inkluzywnych form, jak „my” czy „weźmy” mających na celu „ochronę twarzy” w większym stopniu niż strategia bezpośrednia. Na przykład lekarz powiedział do 25-letniej ciężarnej pacjentki: „Zastosujemy trójstopniową procedurę diagnostyczną”, chociaż oczywiste jest, że procedurę tę będzie stosował tylko lekarz. W kategorii młodszych mężczyzn strategie pozytywnej i negatywnej grzeczności nie były stosowane - wobec pacjentów młodszych od lekarza i tej samej płci mogły być stosowane bardziej bezpośrednie formy kontaktu. W przypadku kategorii starszych kobiet, jak można było oczekiwać, zaobserwowano

${ }^{47}$ David A. Morand, Language and power: an empirical analysis of linguistic strategies used in superior-subordinate communication, "Journal of Organizational Behavior" 2000, s. 235-248. 
największą liczbę strategii grzeczności negatywnej i całkowity brak grzeczności pozytywnej.

W interakcjach lekarzy z pacjentami starszymi od nich, zarówno z mężczyznami, jak i z kobietami, widać więcej respektu i dystansu, stąd też obecność takich fraz jak: „Proszę”, „Czy może Pan/Pani”, „Czy mógłby Pan/mogłaby Pani”, które wskazują na częstsze korzystanie z negatywnej grzeczności. W kategoriach, w których lekarz i pacjent byli odmiennych płci, zaobserwowano najniższą częstość występowania negatywnej grzeczności.

Zupełny brak strategii bezpośredniej i strategii unikania aktów zagrożenia twarzy (FTA) jest normalnym i oczekiwanym rozkładem danych, gdyż interakcje lekarz-pacjent są przykładami relacji transparentnych i oczekuje się, że pacjenci po prostu zgłaszają swoje problemy, a nie uciekają się do wskazówek czy aluzji, lekarz natomiast powinien czuć się pewnie, zadając pytania i zdobywając informacje.

Rycina 2. przedstawia częstość stosowania solidarności i grzeczności w czterech grupach, w których wiek i płeć pacjentów stanowią zmienne niezależne.

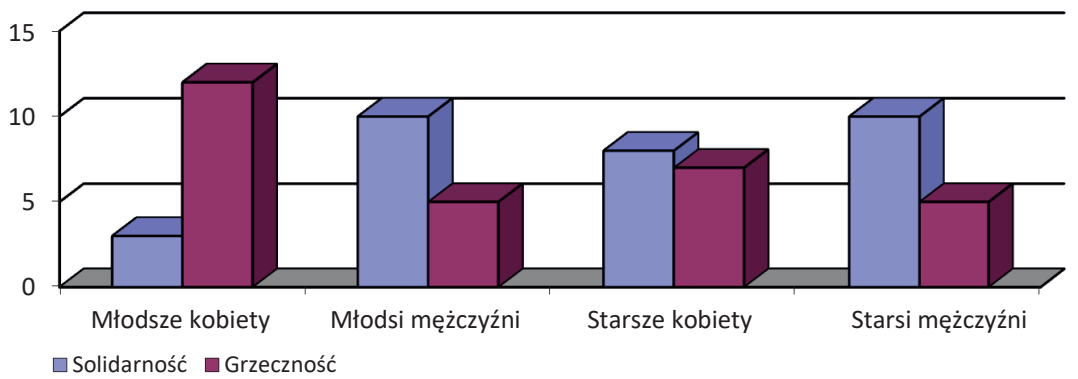

Rycina 2. Rozkład występowania grzeczności i solidarności (opracowanie własne)

W przypadku pacjentek młodszych od lekarza obserwowano najniższy poziom solidarności, ale stosowane były wobec nich najbardziej uprzejme sformułowania. Na przykład podczas wywiadu z 29-letnią pacjentką lekarz zapytał: „Jesteś już po operacji?”. Posłużył się wyrażeniem w drugiej osobie liczby pojedynczej („ty”), znamionującym szczerość lub solidarność, ale zdarzyło się to tylko jeden raz. Zwracanie się do grupy pacjentów przez „wy” może być oznaką grzeczności.

W przypadku pacjentów młodszych od lekarza sytuacja jest odwrotna. Lekarz stosował głównie formę bezpośrednią, mówiąc „ty”, np. „Zdejmij 
koszulę". Oczywiście wynika to z faktu, że obaj rozmówcy są tej samej płci i lekarz nie czuje potrzeby zaznaczania dzielącego ich dystansu. Lekarz i pacjent posługują się mową „między nami mężczyznami” i zachowują się w sposób bardziej bezpośredni.

W odniesieniu do pacjentów starszych od lekarza, badani lekarze często posługują się formą „ty”. Na przykład lekarz instruuje 59-letniego pacjenta: „Teraz przetrzyj...”, przez co dystans między nimi skraca się i rozmowa brzmi bardziej szczerze. Natomiast przy zwrotach takich jak: „Wie Pan/Pani”, poziom grzeczności podnosi się, ponieważ lekarz okazuje pacjentowi szacunek, ale poziom solidarności przewyższa poziom grzeczności. Na rycinie 2. najbardziej rzucającym się w oczy wynikiem jest to, że tylko w grupie młodszych pacjentek lekarze zwracają uwagę na wiek i płeć swoich rozmówczyń. W odniesieniu do młodszych pacjentek zachowują się grzecznie, natomiast solidarność okazują tak samo często, jak we wszystkich pozostałych kategoriach pacjentów.

Nawiązując do założeń medycyny narracyjnej, można zaobserwować, że lekarze cenią sobie otwarte narracje, ponieważ są one naturalnym elementem konwersacji i można w nich łatwiej przedstawiać nierozwiązane i trudne sytuacje życiowe ${ }^{48}$. W rozmowie $z$ pacjentem lekarze niekiedy muszą modyfikować tę „otwartość” narracji pacjentów i starać się konstruować sens relacjonowanych problemów zdrowotnych, nawet jeśli nie są w stanie w pełni pojaćc, co się w życiu pacjenta zdarzyło i dlaczego.

Przedstawiony niżej przykład obrazuje sposób, w jaki lekarze i pacjenci poruszaja się $\mathrm{w}$ narracji, nawet jeśli opowieść może nie zostać $\mathrm{w}$ pełni zrozumiana. Komunikat zwrotny lekarza („OK”) zdaje się sugerować, że rozumie on, co pacjentka dotąd powiedziała, i że nie oczekuje dalszego ciągu historii. Pacjentka natomiast przyznaje, że nie wie, dlaczego upadła:

Przykład 1. (lekarz, pacjentka):

L (lekarz): OK. Czy może mi Pani powiedzieć, co Panią tutaj sprowadza dzisiaj? P (pacjentka): Wie Pan, szłam [...] i chciałam przejść przez ulicę i stanęłam na krawężniku [...], i moja noga [...], to znaczy stopa [...], no po prostu poślizgnęłam się i...

L: OK. Już wszystko rozumiem...

Choć ze słów pacjentki nie wynika wyraźnie, dlaczego zaszło opisywane przez nią wydarzenie, można wskazać wyraźne różnice między tą rozmową

${ }^{48}$ Rita Charon, Narrative Medicine..., op. cit. 
a interakcją przedstawioną w przykładzie 2. Tu słowa pacjenta pozostawiają znaczną część wydarzeń bez wyjaśnienia, mimo zastosowania lingwistycznych zabiegów w postaci wyrażeń grzecznościowych:

Przykład 2. (lekarz, pacjent):

L: Miło znowu widzieć Pana. Mam nadzieję, że czuje się Pan lepiej. [...]. To proszę mi powiedzieć, jak się Pan czuje? Jak się Pan czuje?

P: [...] przez ostatnie dwa tygodnie [...] nie sądzę, aby XXXX ${ }^{49}$ działał, [...] no i chyba nie będę już tego brał [...], nie ma sensu brać tego, bo to nic nie daje $[\ldots]$, nic mi nie pomaga $[. .$.$] i nie sądzę, że muszę to dalej brać.$

L: Hmm, $[\ldots]$ w pełni Pana rozumiem [...] - to co Pan sugeruje? [...] to znaczy, co chciałby Pan zasugerować w tej kwestii?

P: Proszę [...]. Nie za bardzo rozumiem [...] to mogę coś zasugerować [...], naprawdę? Wie Pan, czytałem, że ten lek YYYY jest bardzo dobry [...] i wie Pan Doktor, może lepiej, jakbym brał ten lek YYYY [...], może mógłbym zastąpić ten lek tym YYYY [...], bo wie Pan Doktor, znajomemu YYYY pomógł...

Ten przykład pokazuje, z jakiego typu otwartą narracją może się spotkać lekarz, gdy daje pacjentowi „przestrzeń” do swobodnej wypowiedzi i nie inicjuje pytań, które mogłyby doprowadzić do stworzenia bardziej kompletnej narracji. Tego typu otwarta narracja może także powstać wtedy, gdy lekarz uprzejmie zagadnie pacjenta, zachęcając go przy tym do przedstawienia swojego punktu widzenia.

Kolejny przykład pokazuje, że inni pracownicy poradni także mogą stanowić integralną część interakcji, wpływając na podejmowanie decyzji przez lekarza rozmawiającego $z$ pacjentem. Jest to zgodne $z$ uwagą Susan Ehrlich, która pisze, że „uczestnicy, którzy nie są bezpośrednio i aktywnie zaangażowani $\mathrm{w}$ interakcję, mogą także mimo to wpływać na znaczenia i rozumienia, które przypisywane są tej interakcji” ${ }^{50}$. Oto fragment takiej sytuacji:

Przykład 3. (lekarka, pacjentka):

L: Przepraszam, ale tam są pozostali lekarze i muszę [...], to znaczy muszę [...] do nich wyjść na chwilę.

49 XXXX i YYYY zastępują nazwy leków.

50 Susan Ehrlich, Trial discourse and judicial decision-making: Constraining, the boundaries of gendered identities, w: T. Van Dijk, Discourse Studies, London 2007, s. 196. 
P: Pani Doktor zawsze tak wychodzi. [...] Czy Pani kogoś szuka? [...] Bo Pani tak się cały czas rozgląda.

L: Rozumiem, że może Pani nie czuć się komfortowo, gdy opuszczam pokój, ale staram się być na bieżąco $z$ tym, co się dzieje [...], aha, a też będę musiała zadać Pani dodatkowe pytania. [...] Czy mogę liczyć na Panią?

W tym fragmencie interakcji znaczenie owych dodatkowych pracowników polega na tym, że choć nie wnosili oni do interakcji żadnych słów, swoją „obecnością za drzwiami” przyczyniali się jednak do tworzenia narracji pacjentki. Lekarka stara się utrzymać standard uprzejmości i dać pacjentce możliwość decydowania o przebiegu leczenia.

\section{Dyskusja}

W nawiązaniu do pytania badawczego: „Czy wiek i płeć pacjentów mają wpływ na wybierane przez lekarzy strategie grzeczności?”, otrzymane wyniki pokazują, że czynniki te mogą oddziaływać na interakcje między lekarzem a pacjentem. W przypadku grupy pacjentek młodszych od lekarza wszystkie uzyskane dane potwierdzaja, że stosunek lekarza do nich był dość bezpośredni. Jednocześnie w tej grupie wystąpiła druga najwyższa liczba stosowanych przez lekarza strategii pozytywnej uprzejmości. Strategia negatywnej uprzejmości zastosowana w tej grupie zajęła trzecie miejsce we wszystkich czterech kategoriach osób, co wskazuje na niską częstotliwość. Ponieważ pacjentki były młodsze od lekarza, strategie budujące dystans nie były wobec nich wykorzystywane.

Przy definiowaniu strategii grzeczności znaczenie mają także wartości kulturowe, które mogą być różne w różnych krajach. W polskiej kulturze ważną wartością jest okazywanie starszym szacunku, dlatego bezpośrednie wypowiedzi i zdania w trybie rozkazującym (należące do kategorii bezpośredniej) nie są stosowane w kontaktach ze starszymi pacjentami, wobec których preferuje się bardziej uprzejme zwroty. W tej samej grupie wiekowej (tzn. w sytuacji, kiedy lekarz i pacjent są w tym samym lub podobnym wieku), ale składającej się z przedstawicieli różnych płci, pacjentki są bardziej doceniane przez lekarzy, co ma związek z innym aspektem wartości kulturowych. Z badania wynika, że komunikacja między lekarzem a pacjentem kieruje się swoimi własnymi standardami, ale nadal podlega uwarunkowaniom kulturowym. Wziąwszy to pod uwagę, w edukacji medycznej warto wprowadzić program, który w procesie kształcenia 
kompetencji komunikacyjnych przyszłych pracowników służby zdrowia uwzględni zarówno standardy medyczne, jak i aspekty kulturowe.

Koncepcje medycyny narracyjnej i koncepcje opisujące stosowanie strategii grzeczności wchodzą ze sobą w interakcje, grzeczność stanowi integralną część modelu opieki dowartościowującej narracje pacjentów, nawet jeśli się o tym nie wspomina wprost. Obie koncepcje „dają przestrzeń”, w której pacjent ma szansę wypowiadać się swobodnie, mniej lub bardziej spójnie, bez informacji zwrotnych i bez przerywania przez lekarza, przy jednoczesnym zachowaniu elementarnych zasad grzeczności językowej.

W ramach koncepcji medycyny narracyjnej warto badać także wypowiedzi lekarzy i ich rolę w konstytuowaniu narracyjnej spójności, przekładającej się na lepsze rezultaty leczenia. Lekarze mogą pozyskiwać od pacjentów ważne klinicznie informacje, wykorzystując różne techniki grzeczności, które mogą być wplatane w proces tworzenia dyskursu. Uwidacznia się tu paradoks, potencjalnie tworzony przez podejście narracyjne w medycynie: im więcej przestrzeni, w której pacjent może się wypowiadać, tym trudniej jest mu tworzyć spójną narrację. Gdy to się nie udaje, lekarz musi próbować zrozumieć tę „postrzępioną” historię, aby zdecydować, co w niej ma znaczenie dla stanu zdrowia pacjenta.

\section{Podsumowanie i rekomendacje dotyczące dalszych badań}

W świetle wiedzy lingwistycznej tworzenie w ramach konsultacji medycznej warunków sprzyjających kooperacji pozwala budować przyjazne relacje i sprzyja współpracy. Rozumienie strategii grzeczności pozwala lepiej pojąć, dlaczego ludzie mówią to, co mówią, i zwiększa świadomość zakresu funkcji stosowanych form językowych oraz możliwych konsekwencji ich stosowania. Dane przedstawione w niniejszym artykule pozwalają stwierdzić, że konsekwencjami wykorzystywania określonych startegii komunikacyjnych mogą być $z$ jednej strony trudności w podejmowaniu decyzji (wynikające $z$ użycia niebezpośrednich form komunikowania się), z drugiej strony zaś - chętne zabieranie głosu przez pacjentów (wynikające $z$ prowadzenia przez lekarzy luźnych pogawędek). Świadomość tego drugiego zjawiska może pomóc uświadomić specjalistom, że tak poprowadzona rozmowa może być okazją do przekazywania przez pacjenta dodatkowych informacji, które w przeciwnym wypadku nie zostałyby wypowiedziane.

Przedstawiona analiza uzupełnia wyniki badań nad teorią grzeczności, opisującą strategie stosowane w różnych obszarach komunika- 
cyjnych. Jest przykładem opisu strategii grzeczności stosowanych przez użytkowników polszczyzny w konsultacjach medycznych. W analizowaniu tej specyficznej sytuacji komunikacyjnej nacisk kładłam na „zagrożenia dla twarzy” i sposób, w jaki pozytywna grzeczność może „twarzy sprzyjać”. Najbardziej wartościową konsekwencją niniejszego badania jest w moim odczuciu ustalenie, że lekarze i pacjenci we wzajemnej relacji nieustannie podejmują próby tworzenia spójnej narracji i wykorzystują do tego różne dyskursywne narzędzia, w tym również te opisywane przez teorię grzeczności. To spostrzeżenie dostarcza analitycznych ram dyskursywnych, pozwalających $\mathrm{w}$ dalszej perspektywie wnioskować o sposobie, w jaki uczestnicy interakcji (lekarze i pacjenci) współkonstruują narracje i tożsamość pacjenta - szczególnie w interakcjach odnoszących się do chorób przewlekłych.

Na podstawie literatury trudno stwierdzić, czy którekolwiek z przedstawionych $\mathrm{w}$ artykule prawidłowości zostały wykorzystane w programach kształcenia umiejętności komunikacyjnych lekarzy. Otwiera to szerokie pole do dalszych analiz. Ciekawych wyników można oczekiwać również w bardziej szczegółowych badaniach nad związkiem między pozytywną grzecznością a budowaniem porozumienia, oraz nad rolą narracji w przebiegu konsultacji.

W przedstawionym badaniu kluczową rolę odgrywała analiza dyskursu. Okazuje się jednak, że przydatne jest także podejście interdyscyplinarne, które pozwala na przeprowadzenie wszechstronnej, wieloaspektowej oceny interakcji między lekarzem i pacjentem. Dalsze badania nad tym, w jaki sposób można integrować różne perspektywy (w tym także aspekt grzeczności) dla uzyskania pełniejszego zrozumienia tych interakcji, mogłyby skutkować wypracowaniem wskazówek dotyczących praktyk komunikacyjnych w ochronie zdrowia.

(przekład Elżbieta Józefowicz)

\section{Bibliografia}

Barone S.M., Seeking narrative coherence: Doctors' elicitations and patients' narratives in medical encounters, niepublikowana praca doktorska, Victoria University Wellington 2012; https://core.ac.uk/download/pdf/41337614.pdf [dostęp 13.10.2019].

Bazzocchi M., Doctor-patient communication in radiology: a great opportunity for future radiology, „La radiologia medica” 2012, 117, s. 339-353.

Beran J., Doctor-patient communication: Part I - Introduction, Karolinum, Prague 1999. 
Brown P., Levinson S., Politeness: Some Universals in Language Usage, Cambridge University Press, Cambridge 1987.

Byrne P.S., Long B.E.L., Doctors talking to patients: A study of the verbal behaviours of doctors in the consultation, Department of Health and Social Security, London 1976.

Candlin Ch., Candlin S., Health care communication: a problematic site for applied linguistics research, „Annual Review of Applied Linguistics” 2003, 23, s. 134-154.

Charon R., Narrative Medicine: Attention, Representation, Affiliation, „Narrative” 2005, 13, s. 261-270.

Charon R., Narrative Medicine: Honoring the Stories of Illness, Oxford University Press, New York 2006.

Charon R., The Principles and Practice of Narrative Medicine, Oxford University Press, New York 2017.

Chimombo M., Roseberry R.L., The power of discourse: An introduction to discourse analysis, Lawrence Erlbaum Associates, Mahwah, New Jersey-London 1998.

Coulthard M., Ashby M., A linguistic description of doctor-patient interviews, w: M. Wadsworth, D. Robinson (red.), Studies in everyday medical life, Martin Robertson, London 1976.

Creswell J.W., Narrative, pain, and suffering [Review of the book Progress in pain research and management], „New England Journal of Medicine” 2005, 353(15), s. 1637.

Eelen G., A Critique of Politeness Theories, St. Jerome's Press, Manchester 2001.

Eggly S., Health Communication, Routledge, New York 2002.

Ehrlich S., Trial discourse and judicial decision-making: Constraining, the boundaries of gendered identities, w: T. Van Dijk (red.), Discourse Studies, Sage, London 2007, s. 196.

Fairclough N., Language and Power, Longman, London 1989.

Frankel R., Clinical care and conversational contingencies: The role of patients' self-diagnosis in medical encounters, „Text - Interdisciplinary Journal for the Study of Discourse” 2001, 21(1), s. 83-111.

Fraser B., Perspectives on politeness, "Journal of Pragmatics” 1990, 14, s. 219-236.

Goffman E., Interaction Ritual: Essays on Face-to-Face Behavior, Garden City, New York 1967. Graham S.L., Hospitalk: Politeness and hierarchical structures in interdisciplinary discharge rounds, „Journal of Politeness Research. Language, Behaviour, Culture” 2009, Vol. 5, 1, s. 11-31.

Greenhalgh T., Hurwitz B., Ethics and narrative, „British Medical Journal” 1999, 318, s. $48-50$.

Gunnarsson B.-L., Linell P., Nordberg B. (red.), The Construction of Professional Discourse, London 1997, s. 173-200.

Heritage J., Conversation analysis and institutional talk, w: D. Silverman (red.), Qualitative Research: Theory, Method and Practice, Sage, London 1977, s. 161-182. Hydén L.-Ch., Brockmeier J., Health, Illness, and Culture: Broken Narratives, Routledge, London 2008. 
Lakoff R.T., The logic of politeness; or, minding your p's and q's, Chicago Linguistic Society, Chicago 1973.

Leech G., Principles of Pragmatics, Longman, London 1983.

Mansfield C., McLean K., Lilgendahl J., Narrating traumas and transgressions: Links between narrative processing wisdom and well-being, „Narrative Inquiry” 2010, 20(2), s. 246-273.

Morand D.A., Language and power: an empirical analysis of linguistic strategies used in superior-subordinate communication, „Journal of Organizational Behavior” 2000, 21, s. 235-248.

Nevala M., Accessing politeness axes: forms of address and terms of reference in early English correspondence, „Journal of Pragmatics” 2004, 36, s. 2125-2160.

Nowina-Konopka M., Komunikacja lekarz-pacjent. Teoria i praktyka, Wydawnictwo Uniwersytetu Jagiellońskiego, Kraków 2016.

Ochs E., Capps L., Living Narrative: Creating Lives in Everyday Storytelling, Harvard University Press, Cambridge, MA 2001.

Ostrowska A. (red.), Jak rozmawiać z pacjentem? Anatomia komunikacji $w$ relacji $w$ praktyce lekarskiej, Wydawnictwo IFiS PAN, Warszawa 2017.

Pinker S., Indirect speech, politeness, deniability, and relationship negotiation: Comment on Marina Terkourafi's “The Puzzle of Indirect Speech”, „Journal of Pragmatics” 2011, 43(11), s. 2866-2868.

Piyush R., Kumari A., Chakrawarty A., How can Doctors Improve their Communication Skills?, ,Journal of Clinical and Diagnostic Research: JCDR” 2015, 9(3), s. JE01-JE4.

Riessman C.K., Narrative Methods for the Human Sciences, Sage, Thousand Oaks 2008. Sifianou M., Politeness phenomena in England and Greece, Clarendon, Oxford 1992.

Spiers J., The use of facework and politeness theory, „Qualitative Health Research” 1998, 8, 1, s. 25-47.

Stefaniak K., Władza i tożsamość w komunikacji lekarz-pacjent, Oficyna Wydawnicza Atut-Wrocławskie Wydawnictwo Oświatowe, Wrocław 2011.

Stewart M.A., McWhinney I.R., Buck C.W., The doctor/patient relationship and its effect upon outcome, "Journal of the Royal College of General Practitioners" 1979, 29(199), s. 77-82. Przedruk wrzesień 2018.

Tannen D., Walleat C., Interactive frames and knowledge schemas in interaction: Examples from a medical interview, w: D. Tannen (red.), Framing in Discourse, Oxford University Press, New York 1993, s. 57-76.

Thomas J., Cross-cultural pragmatics failure, „Applied Linguistics” 1995, 4, 2, s. 91-112. Thornborrow J., Power Talk: Language and Interaction in Institutional Discourse, Longman, Harlow 2002.

Waitzkin H., Information giving in medical care, "Journal of Health and Social Behavior" 1985, Vol. 2(2), s. 81-101.

Wodak R., Critical discourse analysis and doctor-patients' interaction, w: B.-L. Gunnarsson, P. Linell, B. Nordberg (red.), The construction of professional discourse, Longman, London 1997, s. 173-200. 
Zembala A., Modele komunikacyjne $w$ relacjach lekarz-pacjent, „Zeszyty Naukowe Towarzystwa Doktorantów UJ Nauki Ścisłe” 2015, 11, s. 35-50.

Zola I., Pathways to the doctor: from person to patient, "Social Science and Medicine” 1973, 7, s. 677-689.

\section{A B S T R A C T}

\section{The concept of discourse politeness in constructing narrative coherence through doctors' elicitations and patients' narratives: a case study of diagnosis in medical discourse in Poland}

This paper aims at showing a study on how doctors and patients negotiate meaning through interaction, concentrating on the role of narrative in the medical encounter. This paper complements more recent approaches to narrative analysis, within implementing the concept of politeness framework to analyze the relationship between doctor elicitations and patient narratives. The study also examines the clinical approach of Narrative Medicine (MN), which proposes patients the "space" in which to create their narratives, to create an interdisciplinary lens for investigating data. The main results show that both patients and doctors try to create narrative coherence. The analysis reveals how the frame of developing narrative coherence presents insights into the interactional narratives as they are co-constructed by participants. This study shows how politeness and NM add to the perception of doctor-patient interaction. Generally, the examination suggests that narrative plays an essential part in forming relevant meanings in medical interactions between the doctor and the patient.

KEY WORDS: narrative medicine, medical discourse, politeness theory, doctor-patient interactions

\section{A B S T R A K T}

Teoria grzeczności a konstruowanie spójności w narracjach lekarzy i pacjentów. Studium diagnozy w polskim dyskursie medycznym

Artykuł ma na celu pokazanie, jak lekarze i pacjenci negocjują znaczenia poprzez interakcję, a szczególnie za pomocą tworzonej narracji. Praca uzupełnia nowsze podejścia do analizy narracyjnej poprzez zastosowanie koncepcji ram grzecznościowych do opisu relacji między aktywnością językową lekarzy a narracjami pacjentów. Interdyscyplinarnym kontekstem analizy danych jest w artykule medycyna 
narracyjna (MN), czyli podejście kliniczne, które proponuje pacjentom „przestrzeń na ich opowieść". Wyniki badania dowodzą, że zarówno pacjenci, jak i lekarze dążą do ukształtowania spójnej narracji. Analiza pokazuje, w jaki sposób w komunikacji między lekarzem a pacjentem rozwijają się ramy spójności narracyjnej, oraz dowodzi, że narracja odgrywa w tego typu interakcjach istotną rolę.

SŁOWA KLUCZOWE: medycyna narracyjna, dyskurs medyczny, teoria grzeczności, interakcja lekarz-pacjent 


\section{LITERATURA I MEDYCYNA - ŹRÓDŁA I PERSPEKTYWY}


Monika Ładoń

Uniwersytet Śląski w Katowicach

\section{Upojona chorobą. $W$ trzewiach świata... Eve Ensler}

„Nie zrozumcie mnie źle. Nie jestem w żadnym wypadku apologetką raka.

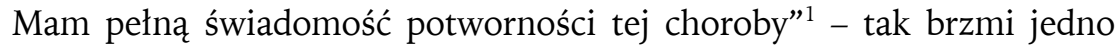
z kluczowych zdań wspomnieniowej książki Eve Ensler - feministki, pisarki, autorki słynnych Monologów waginy, inicjatorki światowego ruchu przeciwko przemocy wobec kobiet V-Day - zdań, które traktować można jak rodzaj obrony przed zarzutem o przesadny entuzjazm wobec choroby. Ów asekuracyjny gest amerykańskiej pisarki wydaje mi się wszak mocno symptomatyczny, stanowi bowiem wyjaśnienie, dlaczego „potworność choroby” - tak oczywista część doświadczenia nowotworowego - nie stanowi meritum opowieści Ensler. To nie jest książka o fizjologii choroby (chociaż przed doznaniami ciała autorka nie ucieka), raczej o specyficznej „filozofii choroby”. I właśnie to przeniesienie punktu ciężkości na ideę, na zestaw wypracowanych poglądów, gestów i strategii wobec schorzenia, dowartościowuje je, w zastanawiający sposób wzmacnia. Jeśli więc nie apologetka choroby, to jednak co najmniej jej admiratorka. Warto zwrócić uwagę, że postawa Ensler w kręgu narracji o chorobie (ang. illness narrati$v^{2} s^{2}$ ) nie wydaje się odosobniona - stan chorobowy wyzwala w piszących paradoksalną potrzebę gloryfikacji raka. Najtrafniejsza jest tutaj przywołana $\mathrm{w}$ tytule fraza pochodząca $\mathrm{z}$ tomu zapisków $\mathrm{z}$ czasu choroby innego

${ }^{1}$ Eve Ensler, W trzewiach świata. Wspomnienia, przeł. M. Zawadzka-Strączek, Warszawa 2015, s. 16.

${ }^{2}$ Narracje o chorobie - jako rodzaj subgatunku pisania (auto)biograficznego, w którym ciało jednocześnie może mówić i być przedmiotem obserwacji - stanowią podstawę koncepcji medycyny narracyjnej Rity Charon. Zob. Rita Charon, Narrative Medicine: Honoring the Stories of Illness, New York 2006, s. 86. 
pisarza, Amerykanina Anatole'a Broyarda - Upojony choroba. Moment introdukcji w chorobę opisywany jest przez niego jako odczuwanie zachwytu:

W życiu pisarza tak wiele miejsca zajmuje cierpienie - dobrowolne cierpienie retoryczne - że na wieść o raku prostaty doznałem czegoś w rodzaju ulgi, albo wręcz euforii. Poczułem nagle, że oto nadszedł kryzys: prawdziwy kryzys, a przy tym pobrzmiewający echami kryzysu języka, literatury, osobowości. Wydawało mi się, że moje istnienie - czyli to, co myślę, czuję, robię - nabrało wyraźnego rytmu, że zaczął bić licznik, jak w taksówce, że obowiązuje mnie metrum, jak w poetyce ${ }^{3}$.

I to nie klasyczny już topos galopującego czasu okaże się najważniejszy; i u Ensler, i u Broyarda kluczowa będzie poetyka, a w jej ramach miejsce na indywidualne sensy w starych dekoracjach języka. W tych dwóch narracjach rozpoznaję bowiem projekt wyraźnego zwrotu ku metaforom choroby, a dodatkowym elementem je łączącym jest nowotwór - w przypadku Broyarda prostaty, u Ensler - macicy. Dostajemy zatem kancerografie $^{4}$; narracje pisane - jakby zgodnie $z$ komentarzami Susan Sontag z linii frontu, z pola walki z chorobą, która (obok gruźlicy) najsilniej wykorzystuje potencjał metaforyczny, a właściwie jej wojenne oblicze ${ }^{5}$. Warto zapytać, dlaczego $\mathrm{w}$ tekstach $\mathrm{z}$ ostatnich lat ujawnia się świadoma tendencja do metaforyzowania choroby i w jaki sposób wpływa ona

${ }^{3}$ Anatole Broyard, Upojony choroba. Zapiski o życiu i śmierci, przeł. A. Nowakowska, Wołowiec 2010, s. 17.

${ }^{4}$ Używam pojęcia wprowadzonego przez Małgorzatę Okupnik dla wyróżnienia pisania o raku spośród innych patografii. Badaczka tę potrzebę dostrzega nie tylko we wzrastającej liczbie narracji tematycznie związanych z chorobą nowotworową, ale także w ich formie i obecności „zranionego narratora”, „opowiadającego ciałem” z książki Arthura W. Franka The Wounded Storyteller. Zob. Małgorzata Okupnik, W niewoli ciała. Doświadczenie utraty zdrowia $i$ jego reprezentacje, Kraków 2018, s. 215-216 oraz Arthur W. Frank, The Wounded Storyteller: Body, Illness and Ethics, Chicago 1995. O patografiach zob. np. Anne Hunsaker Hawkins, Pathography: Patient Narrative of Illness, 1991; eadem, Reconstructing Illness. Studies in Pathography, West Lafayette 1999; Edyta Zierkiewicz, Patografia jako zjawisko kulturowe i jako narzędzie nadawania znaczeń chorobie przez wspótczesnych pacjentów, 2012; Iwona Boruszkowska, Defekty. Literackie auto/pato/grafie - szkice, Kraków 2016.

${ }^{5}$ Zob. Susan Sontag, Choroba jako metafora. AIDS i jego metafory, Warszawa 1999. O zmaganiach amerykańskiej pisarki z metaforą w przywołanym eseju oraz w zapiskach dziennikowych i rozmowie z Jonathanem Cottem piszę obszerniej w książce Choroba jako literatura. Studia maladyczne (Katowice 2019) w części zatytułowanej Wokót Susan Sontag. Czy metafora może zabić?. 
na konceptualizowanie tego, co symboliczne, kulturowe, społeczne i polityczne. Przyglądam się narracji kobiecej z pytaniem, dlaczego doświadczenie choroby związanej ze sferą seksualności owocuje tak silnie metaforycznym opisaniem własnej kondycji.

\section{Kryzys ciała, kryzys świata}

[...] ta książka jest jak tomografia komputerowa, przekrojowe badanie wychwytujące obrazy, doświadczenia, myśli i wspomnienia, mające początek w moim ciele. Wykonanie tomografii to jedyny sposób, w jaki mogłam opowiedzieć tę historię. Ponieważ byłam otwierana, cewnikowana, poddawana chemioterapii, szpikowana lekami, nakłuwana i podpinana do portów, musiałam zrezygnować z tradycyjnej narracji. [...] Wrażenia. Sceny. Promienie. Tomografie ${ }^{6}$.

Co zatem prześwietla zrywająca z chronologią opowieść autorki Monologów waginy? Jakie „przekroje i zbliżenia” oddaje? Już cytat, od którego rozpoczęłam szkic, sugeruje istnienie biegunów myśli Ensler: od entuzjazmu do tragizmu. Prześledźmy je.

Choroba stawia bohaterkę na baczność, domaga się reakcji, wzmaga czujność, a porażenie po diagnozie i rodzaj apatii szybko zostają przezwyciężone. Choroba nowotworowa ustanawia ważną cezurę w życiu Ensler, a dodatkowo wymusza na niej konfrontację z przeszłością, odbywającą się właśnie poprzez ciało: „Nowotwór wyrwał mnie siłą z dotychczasowego oddzielenia i wrzucił w samo jądro kryzysu mojego ciała" ${ }^{7}$, przyznaje bohaterka. Wygnanie z własnego ciała, jakiego doświadczyła Ensler, było konsekwencją szeregu traum, mających swój początek w dzieciństwie: dom pełen przemocy, również seksualnej, obcość matki, późniejsza anoreksja czy kompulsywny seks. Tej pogardzie dla ciała towarzyszyło też poczucie obcości wobec Ziemi, co w rytmie powrotu do siebie w czasie choroby okaże się fundamentalne. Pozostaję jednak na razie przy ciele, jest ono bowiem przywoływane przez Ensler jak mantra. Rak zostaje potraktowany jak dar i możliwość nawiązania kontaktu z zaniedbywanym obszarem cielesności:

Moje ciało przestało być abstrakcją. Rozcinano je, podłączano do rurek, odsączano rozmaitymi woreczkami i cewnikami, raniono i nakłuwano

${ }^{6}$ Eve Ensler, $W$ trzewiach świata..., op. cit., s. 17.

${ }^{7}$ Ibidem, s. 15. 
igłami. Stałam się krwią, kałem, moczem i ropą. Byłam rozpalona i bardzo słaba, miałam mdłości i gorączkę. Byłam z ciała, byłam w ciele. Byłam ciałem. Ciało, ciało, ciało. Rak, choroba patologicznie dzielących się komórek, wyrwała mnie $z$ mojego oddzielenia i na nowo połączyła mnie $z$ moim ciałem $[\ldots]^{8}$.

U Ensler ta pozytywna waloryzacja nowotworu to coś więcej niż pogodzenie się z losem, to odmiana losu. Pisarka przefiltrowuje niejako chorobę przez osobowość i postawę życiową, ufundowaną na odrzucaniu złych wieści i rozczarowań oraz niezgodzie na ponure wymiary egzystencji. „Złe rzeczy zamieniam na dobre” - przekonuje. „Nie chodzi o to, że nie widzę otaczającego świata - dodaje - Nie odrzucam rzeczywistości. [...] Ale wkładam wiele pracy w to, żeby stała się inna" ${ }^{9}$. Ta specyficzna perspektywa jest stale obecna we wspomnieniach o chorobie - Ensler dostrzega okrucieństwo choroby, czuje je na własnej skórze, ale jednocześnie znajduje W sobie gotowość, by cierpienie przerobić na doświadczenie budujące. W przestrzeni języka to budowanie sensów rodzi się dzięki metaforze. Potrzeba ta jest reakcją na dojmujące doświadczenia fizjologiczne i cielesne upokorzenia, a zarazem - również na banalność chorowania, zobojętnienie wobec przedłużających się kuracji, niemoc ciała, które - dotychczas posłuszne i dające się sterować - buntuje się, co niecierpliwi i chorą, i jej lekarzy. Ostatni wątek, związany z lekarzami, dowodzi jeszcze jednej motywacji wręcz przemetaforyzowanego stylu Ensler. To poszukiwanie języka, który mógłby stanowić przeciwwagę dla medycznej nomenklatury. Co ciekawe, pisarka czujnie tropi także lekarskie uniki, uciekanie w eufemizmy. Po omówieniu z lekarzami wyników tomografii formułuje wnioski w trybie zarzutów:

Plamy to eufemizm [...]. Nie mogli powiedzieć: guz. Nie mogli powiedzieć: Widzimy duże guzy na pani wątrobie. Dlatego mówią o plamach. To takie idiotyczne słowo: plamy. Nawet wymawiając je, czujesz się głupio. Dlaczego

${ }^{8}$ Ibidem, s. 16. Znaczenie ciała mocno akcentuje Rita Charon, przekonując, że jest ono współautorem opowieści o życiu, a choroba staje się szczególną okazją do tego, by usłyszeć jego głos. Komunikacja z ciałem - jak dowodzi przykład Ensler bywa tajemnicza i trudna, a to przez wrażenie, że ciało mówi „obcym językiem”. Ciało w perspektywie medycyny narracyjnej poddaje się translacji, ujawnia swe znaczenia, pozwala się zinterpretować $\mathrm{i}$ „w pewien sposób uczynić przezroczystym”. Zob. o tym w: Rita Charon, Narrative Medicine..., op. cit., s. 87-88.

${ }^{9}$ Eve Ensler, $W$ trzewiach świata..., op. cit., s. 200. 
nie mogli rozmawiać ze mną otwarcie? Dlaczego nie mogli powiedzieć mi prawdy? Potrzebuję prawdy ${ }^{10}$.

Ta deklaracja i potrzeba nie oznaczają wcale, że pacjentka przejdzie na stronę lekarzy, że przejmie ich język. Przeciwnie - na precyzji ich formuł zbuduje własne, metaforyczne. Jeden z bardziej znamiennych fragmentów:

Nie mówię im, że usuwają coś, co wygląda jak guz, ale co jest tak naprawdę wzniesionym w moim wnętrzu pomnikiem $z$ ciała. Pomnikiem ogromnym i okrągłym. Naprężoną kulką komórkowej włóczki, w którą wplecione są opowieści kobiet, łzy, głuche krzyki, kołyszące się klatki piersiowe i rozpaczliwa samotność towarzysząca przemocy. To obca istota zrodzona z okrucieństwa - każde jej naczynko jest nitką opowieści. Moje ciało rzeźbiło tego guza całymi latami, modelując odłamki bólu i cierpienia, nadając kształt glinie wspomnien ${ }^{11}$.

Na to zderzenie języków - pacjentki i jej lekarzy - można spojrzeć z perspektywy medycyny narracyjnej Rity Charon, widząc w oskarżeniach Ensler i jej poczuciu obcości w świecie języka medycznego wołanie o „uważne słuchanie” (ang. attentive listening), o które wielokrotnie apelowała Charon ${ }^{12}$. Wsłuchanie się $\mathrm{w}$ mowę pacjenta, inną i nieprofesjonalną, wiąże się z honorowaniem jej znaczenia na równi z klinicznym obrazem choroby i chorującego, jaki tworzy lekarz, posługując się metodami i nomenklaturą typową dla swojej profesji ${ }^{13}$. Charon jest przekonana o wartości, jaką do narracji o chorobie wnosi metafora. Przywołując badania takich uczonych, jak Cynthia Ozick, James Boyd White oraz George Lakoff i Mark Johnson, podkreśla, że metafora organizuje nie tyle (nie tylko) literaturę, ale wszelkie nasze akty myślenia i życia ${ }^{14}$.

10 Ibidem, s. 21.

11 Ibidem, s. 36.

12 Rita Charon, Narrative Medicine..., op. cit., s. 186-192.

13 O potrzebie „rekonstrukcji typowego wywiadu klinicznego”, wynikającej z uwzględnienia postulatów medycyny narracyjnej, pisze na gruncie polskim Michał Skrzypek w: idem, Medycyna narracyjna jako model zhumanizowanej medycyny w ujęciu socjomedycznym, Lublin 2013, s. 73-75. Badacz konkluduje, że wartość podejścia narracyjnego kryje się $z$ jednej strony $w$ dowartościowaniu perspektywy osoby chorej i jej opowieści, z drugiej - w poszerzeniu zasobu narzędzi terapeutycznych lekarza i wyczuleniu go na „umiejętność empatycznego słuchania” (ibidem, s. 83).

14 Rita Charon, Narrative Medicine..., op. cit., s. 118-119. Charon pisze, że myślenie - naukowe tak samo jak poetyckie - jest metaforyczne, ponieważ „metafora to 
Odkryty w ciele Ensler guz to „dziecko traumy”, ale nie tylko tej jednostkowej; warto bowiem pamiętać, że choroba ciała sprzężona jest u niej z chorobami świata, więcej nawet - nowotwór pisarki stanowi reakcję ciała $\mathrm{w}$ potrójnym sensie: po pierwsze na własne nieprzepracowane traumy z dzieciństwa, po drugie na opowieści innych kobiet o doświadczanych przez nie cierpieniach i wreszcie - na „raka, który toczy cały świat”. W trzewiach świata... jest książką opartą w dużej mierze na - znów podszytej metaforą - analogii między własnym cierpiącym ciałem a wyniszczanym systematycznie ciałem świata. Oto charakterystyczny fragment wspomnienia pooperacyjnego:

[...] pokazują mi ją na ekranie komputera: ogromną czarną plamę w moich wnętrznościach. Tego samego dnia, w którym dochodzi do eksplozji platformy wiertniczej i wycieku ropy naftowej, zatruta Zatoka Meksykańska w jakiś sposób pojawia się nagle w moim ciele. Prawie pół kilo ropy. Ponad dziewięć milionów litrów ropy dziennie. Ropień śródbrzuszny. Infekcja pooperacyjna, wyciek w następstwie eksplozji, zakażenie krwiobiegu oceanu ${ }^{15}$.

Na podobnej analogii oparte są równolegle toczące się działania naprawcze, które pisarka tak relacjonuje:

Po dwóch falstartach inżynierom BP udaje się wreszcie podłączyć półtorakilometrowy rurociąg [...], a następnie przekierować część surowca na pokład statku wiertniczego. Przez dziewięć dni rurociąg zasysa około dwudziestu dwóch tysięcy baryłek ropy [...]. W ciągu trzech kolejnych dni zespół z centrum Sloan Kettering trzykrotnie wprowadza do mojego ropnia rurki, żeby wyssać ropę ${ }^{16}$.

Jak rozumieć te analogie Ensler? Czy kryje się za nimi masochistyczna potrzeba intensyfikacji własnych cierpień? Czy może próba polemiki $z$ indywidualizującym znaczeniem choroby? Chorując nie tylko na tle świata, ale wręcz z nim, Ensler wypełnia wciąż swe aktywistyczne działania, pisze właściwie rodzaj manifestu politycznego. Jej ból staje się tożsamy z cierpieniem pelikanów, delfinów i fok w Zatoce Meksykańskiej;

sposób na podróże ludzkiego mózgu". Zarazem metafora jest - obok m.in. gatunku, narratora czy aluzji - elementem budującym „uważne czytanie” (ang. close reading), w trakcie którego zwraca się uwagę na ukształtowanie tekstu i jego „pracę” oraz wpływ na czytelników (s. 116).

${ }^{15}$ Eve Ensler, $W$ trzewiach świata..., op. cit., s. 76.

${ }^{16}$ Ibidem, s. 77-78. 
z kolei przetoka w jej organizmie jest ekwiwalentem przetok powstałych w wyniku gwałtów wojennych na ciałach innych kobiet. Opowiadając o sobie, sugerując nie naukowe, a właśnie metaforyczne zarażenie od spotkanych w Kongo kobiet, Ensler jednocześnie próbuje wpisać pojedyncze cierpienie w doświadczenie naszego bycia w świecie. Tym samym aktywistyczny i ideowy gest pisarki jest apelem o przebudzenie, o odnalezienie więzi z własnym ciałem, a w konsekwencji - z naturą. Ale stanowi też ważny znak dowartościowania choroby w ogóle. Wspominając najciemniejszy okres chorowania, czas chemioterapii, pisarka buduje metaforyczny obraz powrotu do siebie i świata: „[...] przenosisz się do jakiejś mistycznej przestrzeni, gdzie zatapiasz się w swoje ciało, w głąb jaskini, jaką jest twoje ciało. Zanurzasz się tak głęboko, że wreszcie dosięgasz dna świata"17.

Wyznanie Ensler brzmi jak mała epifania, przywodzi na myśl upragnioną zmianę, która organizuje sensy wielu metafor rozpisywanych przez autorkę Monologów waginy. Nowotwór to "alchemik, zwiastun zmian”"18, powiada na przykład. W tym samym duchu Ensler sięga do świata żywiołów i nazywa chorobę „drugim podmuchem wiatru”:

Drugi podmuch wiatru zrywa się, kiedy sądzimy, że nadszedł już koniec, gdy nie możemy zrobić kolejnego kroku, wziąć kolejnego oddechu. I nagle już możemy. [...]

Co oznacza drugi podmuch wiatru, drugie życie? [...] To, że dotykam ciemności i wkraczam w nią, poznaję smak śmierci za sprawą blizny przebiegającej przez środek mojej klatki piersiowej [...]. Płonę, drugi podmuch wiatru jest bowiem też ogniem przepalającym nasz strach ${ }^{19}$.

\section{Głos histeryczki}

Przywoływane wyżej przykłady dowodzą, jak blisko z obszaru onkologii do obszaru ontologii - jak powiedziałby autor innej kancerografii, Christopher Hitchens ${ }^{20}$. Praktyka tak silnej metaforyzacji może jednak nie tylko dowartościowywać chorobę, wzmacniać jej estetyzujące elementy, ale i być sposobem na zakrycie własnego ciała, poddawanego przecież szpitalnym praktykom naruszającym granice intymności. W gruncie rzeczy

17 Ibidem, s. 177.

18 Ibidem, s. 16.

19 Ibidem, s. 230-231.

${ }^{20}$ Christopher Hitchens, Śmiertelność, Katowice 2013, s. 110. 
jednak Ensler nieustannie gra w swoiste odkrywanie i zakrywanie ciała. $\mathrm{Na}$ tle bogatego zaplecza metafory łatwo odnaleźć fragmenty, w których pisarka nie eufemizuje i nie powstrzymuje się przed opisem nawet najbardziej fizjologicznej i upokarzającej strony swego schorzenia:

Najprzystojniejszy lekarz świata zjawia się w gabinecie, żeby zbadać mój tyłek. No tak: cóż innego mógłby badać? Jestem oczywiście w ciężkim szoku. Leżę na stole, ze spodniami opuszczonymi do kostek, i myślę, że to właśnie ta chwila. Tak wygląda koniec: najpiękniejszy na świecie mężczyzna wie, że mam jakiś koszmarny guz w okrężnicy, odbytnicy albo macicy, i wie, że musi go zbadać. Zdążyłam już umrzeć z powodu upokorzenia i przerażenia, które zlały się teraz w jedno i przekształciły w mieszankę potu i mdłości ${ }^{21}$.

Chorującej kobiecie trudno pozbyć się poczucia, że wystawia własną kobiecość na taksujące spojrzenie mężczyzny skrytego pod lekarskim fartuchem. Gra damsko-męska jest nie tyle celowo wykorzystywana przez Ensler, ile uruchamiana niejako podświadomie, jej choroba bowiem wiąże się z seksualnością i ze znaczeniami, jakie kultura przypisuje tzw. nowotworom kobiecym ${ }^{22}$. Nieoczekiwanie dla siebie pisarka przed operacją przyznaje: „Nie wiedziałam, że jestem tak przywiązana do swojej macicy”"23. Chirurgiczna ingerencja pozbawia kobietę zarówno macicy, jak i jajników,

${ }^{21}$ Eve Ensler, $W$ trzewiach świata..., op. cit., s. 33. Interesuje mnie powiązanie choroby z seksualnością, ale warto zwrócić uwagę na podmiotowe potraktowanie pacjentki w trakcie tego badania i konkluzję Ensler: „Lekarze nie chcą wierzyć, że tak niewiele potrzeba, żeby dać pacjentowi poczucie godności. Wystarczy wypowiedzieć jedno zdanie. Wystarczy okrążyć stół” (s. 34), zgodnie z oczekiwaniami Rity Charon, apelującej o "prawdziwy ludzki kontakt” między chorym a jego lekarzem zob. Rita Charon, The Novelization of the Body, or, How Medicine and Stories Need One Another, 2011, s. 36-38. Zob. o tym także w: Michał Skrzypek, Medycyna narracyjna jako model..., op. cit., s. 76-77.

${ }^{22}$ Tatiana Czerska pisała: „Temat tak zwanych chorób kobiecych (archaiczna nomenklatura, ale nadal używana), czyli tych dotyczących żeńskich organów rozrodczych, pozostaje tabu. Nowotwory macicy, rak jajnika, mięśniaki i torbiele nie utorowały sobie drogi do literatury $\mathrm{w}$ przeciwieństwie do innych medycznych aspektów kobiecego ciała: ciąży, porodu, aborcji czy raka piersi. Polska literatura ignoruje choroby ginekologiczne, nie oswaja z nimi. Próżno w niej szukać - poza Pawlikowską-Jasnorzewską - bohaterek doświadczających na przykład nowotworu szyjki macicy. Wciąż pokutuje podział na choroby lepsze i gorsze, czyste i brudne, klasyfikowane tak w zależności od stopnia ich powiązania $z$ duchem czy fizjologią" (Tatiana Czerska, „Kobieta wyglada jak jej macica - od niej wszystko zależy”. Zapiski i korespondencja Marii Pawlikowskiej-Jasnorzewskiej z okresu choroby, Szczecin 2018, s. 69-70).

${ }^{23}$ Eve Ensler, $W$ trzewiach świata..., op. cit., s. 36. 
szyjki macicy, jajowodów, węzłów chłonnych, naczyń limfatycznych, górnej części pochwy i tkanki otaczającej szyjkę macicy. W pooperacyjnych refleksjach Ensler nie ma jednak rozpaczy i rozpamiętywania straty, jest za to miejsce na próbę zrozumienia podstawowej dla niej kwestii: „dlaczego nowotwór zajął akurat moją macicę?"24. Pisarce najbliższe są odpowiedzi - nazwijmy je tak - fantazmatyczne, splatające zdiagnozowaną chorobę z życiowymi wyborami, ale też losem, osobowością, charakterem, jednym słowem z tym, czego nie da się dowieść naukowo. Tkwiąc w pułapce tych stereotypów i psychoanalitycznych wyjaśnień sprowadzających chorobę do somatyzacji ${ }^{25}$, zgodnie $z$ greckim źródłosłowem w macicy widzi histerię. Tropi więc swą przesadną emocjonalność, wspomina o uznaniu przez rodzinę za „histeryczkę”, o intensywności życia, ale jednocześnie potrafi wyjść z tej kulturowej pułapki, uczynić z niej siłę. Ensler wie bowiem, że histeria to „słowo, które ma sprawić, że kobiety poczują się obłąkane tylko dlatego, że wiedzą to, co widzą. Słowo, które ma tak wiele konotacji: histeryczka, obłąkana, kompletna wariatka, jest niezrównoważona, nie można traktować jej poważnie"26. Histeria staje się tym samym wygodną etykietką służącą do zlekceważenia kobiecego głosu, a równanie

24 Ibidem, s. 46.

25 „Pamiętam, jak wiele lat temu, w okresie, gdy nieustannie chorowałam, moja przyjaciółka, psychoanalityczka, zwróciła się do mnie tym charakterystycznym, lekko protekcjonalnym, a zarazem pełnym współczucia tonem: «To somatyzacja, Eve». [...] Somatyzacja: sposób, w jaki ciało broni się przed nadmiarem stresu, manifestując zaburzenia o charakterze psychicznym za pośrednictwem fizjologicznych symptomów obejmujących brzuch, nerwy, macicę lub pochwę. Przeczytałam też, że kobiety, które padły ofiarą psychicznego, emocjonalnego lub seksualnego wykorzystywania, mają większą skłonność do somatyzacji” (ibidem, s. 47).

${ }^{26}$ Ibidem, s. 48. Krystyna Kłosińska konstatowała: „Wściekła się jej macica» mówi się tak jeszcze o kobiecie, która wykazuje nadmiar energii: życiowej, seksualnej. Nadmiar pożądań. Niezaspokojenie. Stara panna zaś to ta, której macica wyschła, wysuszyła się. Bardziej obeznani w lekturach szkolnych nazbyt uwolnioną cielesność mowy kobiecej zaklasyfikują jako stary syndrom opisany przez Orzeszkową: globus histericus. Krzyk, miotanie, niezborne ruchy, drżenie głosu, grymasy na twarzy spektakl ciała - to histeryczka. W codziennej mowie i "wścik», i wysuszenie macicy, i globus są niewątpliwie synonimami histerii. I są także nazwami symptomów, które ośmieszają kobietę dającą przedstawienie, aktorkę rozgrywającą na udawanej scenie jakąś przemyślną, tylko dla niej zrozumiałą rolę. Po cóż właściwie przywoływać te, wydawałoby się, już zwietrzałe językowe formy? Wystarczy bowiem nastawić ucha tu i ówdzie, aby uznać ich niezwyczajną i zadziwiającą żywotność. Słychać je w mowie zarówno kobiet, jak i mężczyzn” (K. Kłosińska, „Wścieklizna macicy”, Katowice 2006, s. 44). 
macica $=$ histeria unieważnia istotę kobiecego mówienia i sądu. Ensler pyta zatem, jak we współczesnym świecie miałaby wyglądać „niehisteryczna” reakcja świadomej kobiety - świadomej doświadczanego zła, traum, ran świata, i wie, że usunięcie macicy może w jej przypadku jedynie wzmocnić „histerię”: „Bynajmniej nie czuję się teraz - pisze pełna gniewu po operacji - mniej skłonna do histerii. Wręcz przeciwnie, wszystkie te rurki, woreczki i igły wywołują we mnie pewną nerwowość" 27 .

Ensler mówi jednym głosem $z$ feministycznymi badaczkami, które wedle ustaleń Kłosińskiej:

[...] w kulturze, w relacjach płci, władzy, także władzy medycznej (lekarz pacjentka) poszukiwać zaczęły źródeł symptomów zwanych histerycznymi. [...] Feministyczne rozumienie postrzega histerię jako swoisty żeński protojęzyk, który przekazuje poprzez komunikaty ciała to, co nie może być zwerbalizowane. Histeria to swoista kobieca patologia, która mówi do patriarchatu i przeciw niemu ${ }^{28}$.

Konstatacja Ensler brzmi tak samo: „Histeria stanowi reakcję na doświadczenie głębokiej traumy, u której podłoża leży konflikt” ${ }^{29}$. Poddając zatem analizie własne rany, ale i zaangażowaną postawę wobec świata, Ensler kształtuje swą myśl jakby w zgodzie z kulturowym, męskim postrzeganiem histerii jako patologii płodności, a jednak w gruncie rzeczy wbrew niemu. „Pragnąca robić dzieci macica” - jak nieokiełznany zwierz z pism Platona $^{30}$ - wydaje na świat dziecko-guza, ale nie jest ono oznaką normy, zdrowia, niezakłóconej i kontrolowanej przez patriarchat płodności, przeciwnie - jako „dziecko traumy” jest znakiem patologicznych zmian: w sensie medycznym niepohamowanego rozrostu komórek nowotworowych, w sensie metaforycznym krzykiem ciała dotkniętego przemocą i bólem, nie tylko własnym ${ }^{31}$.

27 Eve Ensler, $W$ trzewiach świata..., op. cit., s. 49.

${ }^{28}$ Krystyna Kłosińska, „Wścieklizna macicy”..., op. cit., s. 48.

${ }^{29}$ Eve Ensler, $W$ trzewiach świata..., op. cit., s. 48.

30 O korzeniach „wścieklizny macicy” zob. Krystyna Kłosińska, „Wścieklizna macicy", op. cit., s. 44-47.

31 Ensler swoje zmiany nowotworowe, początkowo całkowicie intuicyjnie, traktuje jak swoiste uwewnętrznienie opowieści gwałconych Kongijek, później jednak znajduje medyczne potwierdzenie: „[...] niedługo po operacji, lekarze oznajmili, że w moim ciele odkryli coś, co zdarza się bardzo rzadko. Komórki nowotworu trzonu macicy doprowadziły do powstania guza pomiędzy pochwą a jelitem, i w odbytnicy zrobiła się przetoka. Jednym słowem, rak dokonał dokładnie tego, co w wyniku 


\section{Przekroczyć wstręt}

Gra w odkrywanie/zakrywanie toczy się także przy użyciu elementów $z$ bieguna upokorzenia i wstrętu. Ensler udaje się niemożliwe: jeśli są jakieś ograniczenia kancerografii, to pisarka je łamie, zadając kłam sądowi Susan Sontag, że „estetyzacja [raka - M.Ł.] wydaje się niemożliwa”32. Ensler zdaje się być pod urokiem tego, co najbardziej stabuizowane; oswaja elementy, od których odwracamy wzrok, porażeni wstrętem. Dzieje się tak choćby ze stomią, którą chora dotyka, głaszcze, bada ,jak jakiś nieznany brejowaty gatunek znaleziony przypadkiem w jaskini”33. Kierują nią chęć poznania, ale i sprawowania - dzięki wiedzy - kontroli nad własnym ciałem. Głęboka chirurgiczna interwencja spowodowała bowiem, że w wyobrażeniu pacjentki wewnątrz jej ciała zapanował chaos, a stomia - jako jedyny widoczny element, rodzaj zewnętrznej wypustki wiązała z cielesnością, nakazywała na nią patrzeć i godzić się z jej ograniczeniami i niemoca. Zgodnie z teorią wstrętu Julii Kristevej, „to nie brak czystości czy zdrowia sprawia, że coś się staje wstrętne; wstrętne jest to, co zaburza tożsamość, system, ład. Co nie przestrzega granic, miejsc, zasad. Pewne pomiędzy, dwuznaczne, mieszane" ${ }^{34}$. Ensler traktuje stomię jak istotę, wręcz jak własne dziecko, które należy pielęgnować; przezwyciężenie wstrętu przychodzi zatem o tyle łatwo, o ile jest częścią walki o własną tożsamość pooperacyjną, którą należy scalić, zbudować na nowo. Wstręt działa jak kategoria, z którą trzeba się ułożyć czy pogodzić właśnie w sytuacji - jak pisze Kristeva - „naruszenia tożsamości”, w przedsionku śmierci, „na granicy swojej kondycji żywej istoty” ${ }^{35}$. W tym wypadku niemożliwe jest, by abject zakryć, usunąć z pola widzenia, zresztą - jak wynika z myśli Kristevej - to, co pokalane, nigdy ostatecznie nie zostanie odseparowane od podmiotu. Monika Bakke dopowiada:

Podmiot zawsze stoi nad otchłanią narodzin i śmierci, początku i końca, zbawienia i potępienia, abject zaś łączy go $z$ tym wszystkim, czego ratio nie

gwałtu spotkało tak wiele tysięcy kobiet w Kongu. Ja natomiast przeszłam tę samą operację, którą przeszło wiele z nich" (E. Ensler, $W$ trzewiach świata..., op. cit., s. 50).

${ }^{32}$ Susan Sontag, Choroba jako metafora..., op. cit., s. 23. Pisząc o mitach ciążących na chorobie nowotworowej, Sontag używa takich przymiotników, jak: „obsceniczny”, „złowrogi”, „ohydny”, „porażający zmysły”, „szokujący”, „odrażający”.

${ }^{33}$ Eve Ensler, $W$ trzewiach świata..., op. cit., s. 59.

${ }^{34}$ Julia Kristeva, Potęga obrzydzenia. Esej o wstręcie, przeł. M. Falski, Kraków 2007, s. 10.

${ }^{35}$ Ibidem, s. 9. 
pojmuje i czego się wystrzega, czyli z rozpadem, przypadkowością i śmiercią; abject zaciera więc jasne granice między właściwym i niewłaściwym, czystym i pokalanym ${ }^{36}$.

To oglądanie stomii staje się też badaniem granic własnego ciała; Ensler obserwuje, jak choroba znosi wyraźne podziały na to, co wewnętrzne i zewnętrzne. Mimo że nie przemilcza fetoru worka ileostomijnego ${ }^{37}$, nie ustaje w poszukiwaniu sposobów na uwznioślenie swego stanu i nowych skrajnych praktyk, którym poddawane jest jej ciało. Tak dzieje się w opisie wszczepiania portu do podawania chemioterapii, co dla Ensler jest „skrajnie przerażające i jednocześnie niewiarygodnie nieziemskie" ${ }^{38}$. Zgroza bierze się $\mathrm{z}$ faktu ingerencji $\mathrm{w}$ ciało i konieczności noszenia pod skórą metalowego przedmiotu. Pacjentka próbuje zatem oswoić kawałek stali w sobie, zamienić go w talizman, wisiorek. Rozbudowując te fantazmaty, Ensler wraca do podstawowego znaczenia słowa „port” i tworzy łagodne pole semantyczne: woda, ocean, lato, przystań, statki i ładunek: „przede wszystkim myślałam o wyruszaniu w drogę, odpływaniu. [...] Wiedziałam,

${ }^{36}$ Monika Bakke, Ciało otwarte. Filozoficzne reinterpretacje kulturowych wizji cielesności, Poznań 2000, s. 26.

${ }^{37}$ Worek ileostomijny uruchamia $\mathrm{w}$ pisarce trudne wspomnienia $\mathrm{z}$ dzieciństwa i sprawia, że akceptacja stomii staje się pogodzeniem z przeszłością i tym, co kał dotychczas oznaczał dla aktywistki. Poświęca tym kwestiom osobny fragment zatytułowany Gówno: „Przez całe lata gówno budziło we mnie głębokie przerażenie. Dręczyły mnie sny o gównie, o oceanach gówna, które mnie zalewało i dusiło. A teraz naprawdę pływałam w morzu gówna, którego nie potrafiłam już kontrolować. Nosiłam torebkę $z$ gównem, bagnistą torebkę pełną niewypowiedzianych myśli, wypływających ze mnie wedle uznania" (E. Ensler, $W$ trzewiach świata..., op. cit., s. 165). Takie fragmenty, bezwzględnie obnażające autorkę i każące mierzyć się jej samej i czytelnikom ze skrajną fizjologią, można zestawić z zapisem choroby Marii Pawlikowskiej-Jasnorzewskiej. Poetka również nie cofa się przed opisem tego, co najbardziej upokarzające i drastyczne w chorobie, jednak częściej niż Ensler ucieka przed dosadnością i ekshibicjonizmem. Barbara Zielińska (Pawlikowska-Jasnorzewska: zapis choroby. Agonia jako upokorzenie, Kraków 1996, s. 157) zauważa: „[...] co jakiś czas poetkę wyraźnie hamuje pamięć o stosowności, o istnieniu pewnej granicy, której nie można przekraczać. Wprowadza więc wyrazy $z$ innych języków czy terminy ze specjalistycznej mowy lekarskiej, przez co bierze jakby w cudzysłów zbytnią drastyczność, łagodzi wydźwięk pewnych słów; [...] o ekskrementach pisze w innym języku [faeces, guano - M.Ł.]". Okaleczone pismo Pawlikowskiej-Jasnorzewskiej jest jednak jej natychmiastową reakcją na okaleczone ciało, Ensler tymczasem spisuje wspomnienia i właśnie ta odmienna perspektywa powoduje, że worek z ekskrementami może nabrać znaczeń metaforycznych.

${ }^{38}$ Eve Ensler, $W$ trzewiach świata..., op. cit., s. 120. 
że z chwilą, w której stalowy port zostanie umieszczony w mojej skórze, udam się w podróż" ${ }^{39}$. W podróż ku zdrowiu, rzecz jasna. Ingerencja w ciało, swoiste oczipowanie, wpływa także na tożsamość kobiety, która czuje się „inna, bioniczna, nadludzka”. Podobnie jak w przypadku stomii, Ensler wciąż dotyka portu, dziwiąc się wybrzuszeniu na skórze, ale czerpiąc z niego siłę, wystawiając na próbę przyjaciół i rodzinę, którzy po raz kolejny okazują się niewtajemniczonymi. Stomia i port, redefiniując granice ciała, separują zarazem od zdrowych, którym obce są „tajemne moce” przepływających przez nie płynów. Chemioterapia ubrana w kostium dobroczynnej metafory gubi u Ensler swój złowrogi cień, staje się jedynie sprzymierzeńcem $\mathrm{w}$ walce $\mathrm{z}$ chorobą, a port jest jak pępowina łącząca pacjentkę $z$ chemią. Pisarka zaryzykuje nawet zdanie: „[byłam - M.Ł.] podpięta do mojej chemicznej matki" ${ }^{40}$.

\section{Mięsność choroby}

Ułudę tej kojącej podróży obnaża jednak inna metafora, silnie organizująca $W$ trzewiach świata..., oparta na języku wojskowym. Ensler wykorzystuje tę retoryczną spuściznę, demaskowaną przez Susan Sontag, a jednak niedającą się usunąć z kancerografii ${ }^{41}$. Inwazja, front walki, atak, kontratak, mechanizm obronny, niszczycielska siła, wróg, bunt - te militarystyczne określenia nie tylko pracują na rzecz realnego wyzdrowienia, ale także zasilają język pisarki. Kreacja wspomnień z czasu choroby staje się wówczas aktem działania, wyrwaniem z półsnu. Chociaż można zrozumieć zmęczenie tą militarystyczną metaforyką i w konsekwencji niechęć Sontag, to warto dostrzec, że za takim kształtem języka kryje się instynkt samozachowawczy, a nie tylko kulturowe uwarunkowania i stereotypy. Zew walki budzi się u Ensler jakby na przekór osobowości pacjentki. Wegetarianka ujawnia wstydliwe marzenia o hamburgerze, zamienia się $\mathrm{w}$ drapieżnika:

Kiedy ból się pogłębiał, kiedy zaczynałam mieć halucynacje i wyobrażać sobie dryfujące komórki nowotworowe, medytowałam o hamburgerach: o mięsie

${ }^{39}$ Ibidem, s. 121.

${ }^{40}$ Ibidem, s. 194.

${ }^{41}$ Zob. Susan Sontag, Choroba jako metafora..., op. cit., s. 68-75; Piotr Szenajch, Trudne umieranie. Narracyjne przedstawienia choroby i śmierci a doświadczenie osób terminalnie chorych, Warszawa 2015, s. 227-291; Dorota Rybarkiewicz, Metafora $w$ dziataniu, Łódź 2017; Małgorzata Okupnik, W niewoli ciała..., op. cit., s. 164-179. 
i bułce. Czułam w ustach smak krwi. Marzyłam o krwi i soku płynącym $z$ grillowanego hamburgera. [...]

Moje ciało rozpaczliwie domagało się mięsa i krwi. Jadłam, wręcz pożerałam. Nie mogłam się powstrzymać. Byłam taka obnażona, taka wygłodniała, że wydawało się to wręcz niestosowne, obsceniczne ${ }^{42}$.

By zrozumieć własną motywację i ideową woltę, Ensler spogląda na świat zwierząt i przypomina sobie lwa pożerającego zebrę - bez przeżuwania, bez godności, ale zgodnie $z$ instynktem. Mięso stanowi preludium do walki na śmierć i życie, ale wydaje się czymś dalece ważniejszym niż jedynie sposobem na zbieranie sił. Potrzeba wgryzienia się w ociekający krwią kawałek mięsa jest podświadomą zgodą na przyjęcie doznań skrajnych, sytuacji granicznych. Mięsność - powie Jolanta Brach-Czaina - „wiąże się z całkowitym odsłonięciem na doznania, jest to bowiem pewna postawa, w której przyjmujemy świat bez osłony, można by powiedzieć: bez skóry" ${ }^{43}$. Choroba każe skonfrontować się z mięsnością organizmu, dodatkowo cięcia chirurgów, niszcząc tkanki, naznaczają ciało ranami i bliznami, a jednocześnie w świat pacjenta wdzierają się niehamowane niczym doznania, gęste doświadczenia, zmysłowe i cielesne ${ }^{44}$. Mięsna dieta (za którą ciało wystawia rachunek ${ }^{45}$ ) przygotowuje do walki $z$ chorobą, a pisarka dosłownie wchodzi na ring. Ensler metaforycznie odwzorowuje tzw. bójkę w dżungli - słynny pojedynek bokserski rozegrany w 1974 roku w Kinszasie pomiędzy Muhammadem Alim a George'em Foremanem: „Ali kładł się na linach, przyjmując setki ciosów. Nawet jego najbardziej zagorzali kibice stawiali w tej walce na Foremana. Lecz Ali walczył o coś innego, ważniejszego. W ósmej rundzie rzucił Foremana na deski" ${ }^{46}$. Zawieszona na ścianie fotografia $z$ bohaterami walki jest dla Ensler jak „wizualna mantra”: „Ali to ja. - powie - Foreman to mój rak” ${ }^{47}$.

${ }^{42}$ Eve Ensler, $W$ trzewiach świata..., op. cit., s. 69, 71.

43 Jolanta Brach-Czaina, Metafizyka mięsa, Warszawa 2018, s. 192.

44 Zob. ibidem, s. 192-193.

45 „Jadłam zdecydowanie za szybko. Wręcz pożerałam każdy kęs. Jeszcze tego samego wieczoru moje ciało zablokowało się nagle jak kosiarka do trawy, w której utknął patyk. Lekarze zdiagnozowali niedrożność, a ja wymiotowałam... długo wymiotowałam. Przez kolejnych dziesięć dni jadłam wyłącznie kostki lodu i schudłam prawie dziesięć kilo - ale pozostałam lwicą" (E. Ensler, W trzewiach świata..., op. cit., s. 72).

46 Ibidem, s. 82.

47 Ibidem, s. 122. 
Przeniesienie sensu choroby na sens walki dowodzi, że o sile tej metafory przesądza nie tylko jej żywotność w języku i kulturze (chociaż i to jest ważne), lecz także rodzaj powiązania $z$ atawistyczną mięsnością życia i to, co z nią zrobimy:

Można powiedzieć, że nasze osobliwe zadanie polega na tym, by wejść w mięsność, ale nie po to, by w niej pozostać, lecz by ją dźwignąć. Czynność uwznioślania - tak nam droga, a tak nieszczęśliwie odrywana od wszelkiej realności - dokonana musi być na samym dnie. Wówczas tylko ruch w górę może być ruchem rzeczywistym, a nie wyimaginowanym, i to, co stanowi stały powód kompromitacji naszych ideałów, może stać się łącznikiem między realnością a pragnieniem. Nasz wysiłek budowania w istnieniu form szybujących musi zwracać się ku mięsności, bo ona jest podstawą. Jest materią pierwszą wszystkiego ${ }^{48}$.

\section{W poszukiwaniu matki}

Przepracowanie gniewu na matkę, która w dzieciństwie nie zapewniła Eve ochrony przed molestującym ojcem, zajęło pisarce wiele lat. Później stosunek do traumy dorastania przyjął formę może nie obrony matki, ale wybaczenia kobiecie uwikłanej w patriarchalne struktury ${ }^{49}$. Czas choroby dodatkowo skomplikował i tak już niełatwe relacje matki i córki. Wszystko zaczęło się - symbolicznie - od operacyjnego nacięcia:

Czy mówiłam wam już, że zrobili mi nacięcie na pępku? Że odkąd sięgam pamięcią, bałam się swojego pępka, nie chciałam go nawet dotykać? Zawsze przyprawiało mnie to o gęsią skórkę. [...] Pępek - jedyny dowód na to, że byłam kiedyś związana z moją matką, miejsce, w którym jej krew i moja krew stawały się jednym. A czy mówiłam wam, że moja matka bardzo się rozchorowała tuż po tym, jak lekarze rozcięli mi pępek? ${ }^{50}$

Ostatnie spotkanie z matką jest inicjatywą Ensler, która - mimo że sama poszukuje wsparcia i opieki - gotowa jest udzielić ich tej, która przez lata

${ }^{48}$ Jolanta Brach-Czaina, Metafizyka mięsa, op. cit., s. 194. s. 11.

49 Ensler mówi o tym w rozmowie z Pauliną Reiter, Miałam tylko głowę, 2015,

${ }^{50}$ Eve Ensler, $W$ trzewiach świata..., op. cit., s. 46. Luce Irigaray napisze: „Blizna nieodłączna, nienaprawialna, to ta, która pochodzi od przecięcia pępowiny” (eadem, Ciało $w$ ciało $z$ matka, przeł. A. Araszkiewicz, Kraków 2000, s. 15). 
lekceważyła ból córki. Nie ma jednak we wspomnieniach Ensler żadnej ckliwej i sentymentalnej sceny pojednania. Córka odczuwa gniew, złość, ale i paraliż przed szczerością, bo wie, że poczucie winy, które może wywołać w umierającej matce, niczego już nie zmieni i nie zrekompensuje. Matka i córka do końca biorą udział w wyścigu, konkurują w długości blizn i liczbie chemioterapii, ale gest wyzwolenia znów przychodzi ze strony córki - to Ensler potrzebne jest uwolnienie się od żalu i głodu uczuć. Impas $\mathrm{w}$ relacjach $\mathrm{z}$ matką $\mathrm{z}$ jednej strony, $\mathrm{z}$ drugiej - potrzeba ustanowienia kobiecej wspólnoty wydaje się w narracji Ensler realizować klasyczne już feministyczne wzorce, w których - jak u Luce Irigaray wraz z życiodajnym mlekiem matki dostajemy lód, ale i stajemy się niewolnicami systemu lustrzanych odbić w sobie: matka w córce, córka w matce, które napędzają tę skomplikowaną formę współzależności. Ukojenie, odczuwane przez Ensler po śmierci matki, jest w gruncie rzeczy pozorne - rodzicielka opuszcza ją w chorobie, a zgonu nie poprzedza katharsis. Ensler zatem mogłaby zapytać: „A jeśli zostaję, czyż nie jestem depozytem twojej śmierci?" ${ }^{51}$. Jeśli choroba jest dla pisarki tak znaczącą cezurą, wręcz ponownymi narodzinami, to utrata matki - metaforyczna i dosłowna - jest jak ciążąca lokata, z niedającymi się spłacić odsetkami od wzajemnych nieporozumień, jak udosłowniony „czarny ląd”, „noc i piekło" naszej kultury ${ }^{52}$. Ensler specyficznie odpowiada na apel Irigaray, by „nie zabijać znów matki, [...] by przywrócić jej życie, matce w nas i między nami" ${ }^{53}$. Nie tylko dlatego, że odkrycie macierzyństwa w chorobie to wydanie na świat „dziecka traumy” i konieczność histerektomii, o czym już pisałam, ale przede wszystkim z racji tego że matczyny trop organizuje Matka-Ziemia. Azyl w nieprzyjaznej przestrzeni szpitala wyznacza pokój z widokiem na drzewo:

Drzewo po raz kolejny dokonało cudu, nie wiedziałam wtedy jeszcze, że drzewo znajdowało się tak naprawdę $\mathrm{w}$ moim wnętrzu i ratowało właśnie moje życie: okazuje się, że taksol - chemioterapeutyk - znajduje się w korze cisu. Co więcej, taksol pozyskuje się zwykle z igieł, aby nie ścinać drzewa. Stabilizuje strukturę komórkową tak skuteczne, że zabójcze komórki nowotworowe nie mogą się dzielić ani rozprzestrzeniać.

${ }^{51}$ Luce Irigaray, I jedna nie ruszy bez drugiej, przeł. A. Araszkiewicz, Warszawa 2001, s. 289.

${ }^{52}$ Eadem, Ciało $w$ ciato..., op. cit., s. 8.

${ }^{53}$ Ibidem, s. 19. 
To właśnie drzewo mnie uspokajało i chroniło, wzmacniało zdrowe komórki tak, żeby strzec je przed kolejnymi atakami. Wreszcie odnalazłam swoją matkę [wyróż. - M.Ł.] ${ }^{54}$.

Niosąca uzdrowienie roślinno-chemiczna matka wyznacza w narracji Ensler splot elementów indywidualnej choroby i przestrzeni aktywizmu, idei, właściwie bowiem książka $W$ trzewiach świata... jest wypełniona tą podwójnością: czytelnik zanurza się $\mathrm{w}$ podobnym stopniu $\mathrm{w}$ trzewiach kobiety, jak i w trzewiach świata, którego potrzebą są nowe idee i czyny. Eve Ensler pokazuje, jak przerobić słabość ciała na siłę politycznego, społecznego i feministycznego manifestu.

Choroba stała się dla pisarki drogą do „dorobienia” ciała do głowy, dodania do racji rozumu i intelektu mięsności, zmysłowości, czucia. W swym radykalizmie Eve Ensler pokazała, że jej własne pogodzenie się $z$ ciałem wiodło przez horror choroby, który - dzięki kulturowym tropom i postawie aktywistki - umiała przepracować ${ }^{55}$. Mimo zatem że Susan Sontag ma rację, gdy obnaża mity, stereotypy, zafałszowania tkwiące w obrazie choroby nowotworowej - jako konsekwencje panoszących się chorobowych metafor - bliżej mi do myśli Kwiryny Ziemby: „[...] opleceni jesteśmy fantazmatami choroby i fantazmatami śmierci, fantazmaty te należą do trzonu kultury śródziemnomorskiej, europejskiej, której rozwój był między innymi ich narastaniem" ${ }^{56}$. Jedna z tez Upojonego chorobą, tekstu Anatole'a Broyarda przywoływanego na początku artykułu, brzmi: „Człowiek chory wszystko widzi jako metaforę" ${ }^{57}$. Metafora wyznaczałaby w narracjach maladycznych rodzaj „kodu genetycznego”, którego nie sposób porzucić, a skoro jest ona jednocześnie podstawą komunikacji i kulturowego dziedzictwa, zrozumiały jest jej potencjał i trwałość, również w tekstach XX i XXI wieku. Metafora choroby pozwala pozostać po stronie nie symptomów czy medycznego dyskursu, ale po stronie rozumienia, ukrytych sensów, uzgadniania ponadindywidualnych znaczeń. Blisko znów do koncepcji medycyny narracyjnej, która łączy kilka perspektyw: zapis

${ }^{54}$ Eve Ensler, $W$ trzewiach świata..., op. cit., s. 138-139.

55 „Myślałam: jestem ciałem! I chcę to powiedzieć wszystkim kobietom: nie trzeba przejść przez czwarty stopień raka i mieć wyciętej połowy organów i wstawionych nowych, by wrócić do swojego ciała. Ale mnie potrzebny był aż taki szok, by się przebudzić, by wrócić, zamieszkać w swoim ciele" (Miałam tylko głowę, 2015, s. 14).

${ }^{56}$ Osoby, Gdańsk 1984, s. 386.

${ }^{57}$ Anatole Broyard, Upojony choroba..., op. cit., s. 21. 
autentycznego i indywidualnego doświadczenia choroby, ukształtowane literacko i kulturowo elementy narracji oraz optykę medyczną.

\section{Bibliografia}

Bakke M., Ciało otwarte. Filozoficzne reinterpretacje kulturowych wizji cielesności, Uniwersytet im. Adama Mickiewicza, Wydawnictwo Naukowe Instytutu Filozofii, Poznań 2000.

Boruszkowska I., Defekty. Literackie auto/pato/grafie - szkice, Wydawnictwo Uniwersytetu Jagiellońskiego, Kraków 2016.

Brach-Czaina J., Metafizyka mięsa, w: eadem, Szczeliny istnienia, Dowody na Istnienie, Warszawa 2018.

Broyard A., Upojony chorobą. Zapiski o życiu i śmierci, wyb. i oprac. A. Broyard, słowo wstępne O. Sacks, przeł. A. Nowakowska, Wydawnictwo Czarne, Wołowiec 2010. Charon R., Narrative Medicine: Honoring the Stories of Illness, Oxford University Press, New York 2006.

Charon R., The Novelization of the Body, or, How Medicine and Stories Need One Another, „Narrative” 2011, Vol. 19, nr 1, s. 36-38.

Czerska T., „Kobieta wygląda jak jej macica - od niej wszystko zależy”. Zapiski i korespondencja Marii Pawlikowskiej-Jasnorzewskiej z okresu choroby, w: eadem, Diarystki: tekst i egzystencja, Wydawnictwo Naukowe Uniwersytetu Szczecińskiego, Szczecin 2018.

Ensler E., W trzewiach świata. Wspomnienia, przeł. M. Zawadzka-Strączek, Wydawnictwo W.A.B., Warszawa 2015.

Frank A.W., The Wounded Storyteller: Body, Illness and Ethics, University of Chicago Press, Chicago 1995.

Hawkins Hunsaker A., Pathography: Patient Narrative of Illness, „Culture and Medicine” 1991, Vol. 171.

Hawkins Hunsaker A., Reconstructing Illness. Studies in Pathography, Purdue University Press, West Lafayette 1999.

Hitchens Ch., Śmiertelność, przeł. R. Madejski, Wydawnictwo Sonia Draga, Katowice 2013.

Irigaray L., Ciało $w$ ciało z matka, przeł. A. Araszkiewicz, eFKa, Kraków 2000.

Irigaray L., I jedna nie ruszy bez drugiej, przeł. A. Araszkiewicz, w: A. Nasiłowska

(red.), Ciało i tekst. Feminizm w literaturoznawstwie - antologia szkiców, Instytut Badań Literackich, Warszawa 2001.

Kłosińska K., „Wścieklizna macicy”, w: eadem, Miniatury. Czytanie i pisanie „kobiece”, Wydawnictwo Uniwersytetu Śląskiego, Katowice 2006.

Kristeva J., Potęga obrzydzenia. Esej o wstręcie, przeł. M. Falski, Wydawnictwo Uniwersytetu Jagiellońskiego, Kraków 2007.

Ładoń M., Choroba jako literatura. Studia maladyczne, Stowarzyszenie Inicjatyw Wydawniczych, Wydawnictwo Naukowe „Śląsk”, Katowice 2019. 
Miałam tylko głowę. Z Eve Ensler rozmawia Paulina Reiter, „Wysokie Obcasy” nr 14 (823) z 4.04.2015.

Okupnik M., W niewoli ciała. Doświadczenie utraty zdrowia i jego reprezentacje, Universitas, Kraków 2018.

Osoby, wyb., oprac. i red. M. Janion, S. Rosiek, Wydawnictwo Morskie, Gdańsk 1984. Rybarkiewicz D., Metafora $w$ dziataniu, Wydawnictwo Uniwersytetu Łódzkiego, Łódź 2017.

Skrzypek M., Medycyna narracyjna jako model zhumanizowanej medycyny w ujęciu socjomedycznym, w: M. Skrzypek (red.), Socjologia medycyny w multidyscyplinarnych badaniach humanizujacych biomedycyne, Wydawnictwo KUL, Lublin 2013, s. 73-75.

Sontag S., Choroba jako metafora. AIDS i jego metafory, przeł. J. Anders, PIW, Warszawa 1999.

Szenajch P., Trudne umieranie. Narracyjne przedstawienia choroby i śmierci a doświadczenie osób terminalnie chorych, Slawistyczny Ośrodek Wydawniczy Instytutu Slawistyki PAN, Warszawa 2015.

Zielińska B., Pawlikowska-Jasnorzewska: zapis choroby. Agonia jako upokorzenie, w: K. Biedrzycki (red.), Stulecie skamandrytów, Universitas, Kraków 1996.

Zierkiewicz E., Patografia jako zjawisko kulturowe i jako narzędzie nadawania znaczeń chorobie przez wspótczesnych pacjentów, „Teraźniejszość - Człowiek - Edukacja” 2012, nr 1, s. 49-61.

\section{A B S T R A C T}

\section{Intoxicated by illness. In the Body of the World... by Eve Ensler}

Eve Ensler is an American writer, the authoress of famous The Vagina Monologues, a feminist, the founder of a global activist movement to end violence against women and girls (V-Day). This article is devoted to interpretation of a memoir book by Ensler written after the cancer experience. Ensler writes simultaneously about physiological and philosophical side of cancer. She doesn't avoid naturalistic descriptions of her own body, but she appreciates her condition. Ensler writes her patography as a person "intoxicated by illness", according to Anatole Broyard's words. The meaning of a cancer disease is formed on several levels. For example, the metaphor is most important for language. Ensler uses (or abuses) metaphors against warnings by Susan Sontag. The authoress is also trying to connect her own disease with the suffering of the world. Thus, the book turns into a political and social manifesto.

KEY WORDS: Eve Ensler, cancer, metaphor, Susan Sontag 


\section{A B S T R A K T}

\section{Upojona chorobą. W trzewiach świata... Eve Ensler}

Eve Ensler to amerykańska pisarka, autorka słynnych Monologów waginy, feministka, inicjatorka światowego ruchu przeciwko przemocy wobec kobiet (V-Day). Artykuł jest poświęcony interpretacji wspomnieniowej książki Ensler, napisanej po doświadczeniu choroby nowotworowej. Pisarka zajmuje się zarazem „fizjologią choroby" i „filozofią choroby”. Nie stroni zatem od naturalistycznych opisów swego ciała, ale jednocześnie dowartościowuje swój stan. Swoją patografię pisze jako osoba „upojona chorobą”, jak to określił Anatole Broyard. Budowanie znaczenia choroby toczy się na kilku poziomach. W planie języka najważniejsze są metafory, których Ensler używa (a nawet nadużywa) niejako wbrew ostrzeżeniom Susan Sontag. Inny poziom znaczeń to powiązanie intymnego chorowania z cierpieniem świata. Tym samym książka $W$ trzewiach świata... zamienia się $\mathrm{w}$ manifest polityczny i społeczny.

SŁOWA KLUCZOWE: Eve Ensler, choroba nowotworowa, metafora, Susan Sontag 
Olga Osińska

Uniwersytet Warszawski

\section{"Ja rozumiałem, tylko nie mogłem mówić". O twórczości Leo Lipskiego jako afatyka. Rekonesans}

\section{„Język, którym myślę, rozpada się i kruszy..."}

Twórczość Leo Lipskiego dopiero w ostatnich latach stała się przedmiotem bardziej ożywionej dyskusji ${ }^{1}$. W jej kontekście badaczki i badacze eksponują doświadczenie rozpadu systemu językowego, które zajmuje szczególne miejsce w prozie autora Piotrusia. Właściwy twórczości Lipskiego stan kryzysu języka wiążą oni między innymi z neurologicznymi zaburzeniami pisarza, które w istotny sposób utrudniały mu - czy też niemal uniemożliwiały - komunikowanie się. Tym bardziej pociągające wydaje się przyjrzenie się jego twórczości z perspektywy współczesnej wiedzy na temat afazji. Przy okazji warto też postawić ogólniejsze pytanie: czy studia logopedyczne, zastosowane jako pretekst do skonstruowania narzędzi literaturoznawczych, pozwalają lepiej zrozumieć oryginalną, hermetyczną twórczość Lipskiego?

Próba zastosowania badań interdyscyplinarnych, łączących wiedzę medyczną z analizą literaturoznawczą, nie jest pomysłem nowym. Afazją z punktu widzenia teorii literatury interesował się już Roman Jakobson, który, korzystając ze znakomicie wyposażonej biblioteki medycznej

${ }^{1}$ Zob. „Mały Format” 2018, nr 5; http://malyformat.com/issue/052018/ [dostęp 28.11.2018]; Jarosław Błahy, Literatura jako lustro. O projekcji $i$ odbiciach fizjologicznych $w$ twórczości Leo Lipskiego, Wydawnictwo FORMA, Szczecin 2009; Hanna Gosk, Jesteś sam w swojej drodze, Izabelin 1998; Adam Lipszyc, Zamurowani: Schulz, Lipski, Hering, Warszawa 2018; Czerwone listy. Eseje frankistowskie o literaturze polskiej, Kraków-Budapeszt-Syrakuzy 2018; Jagoda Wierzejska, Retoryczna interpretacja autobiograficzna. Na przyktadzie pisarstwa Andrzeja Bobkowskiego, Zygmunta Haupta i Leo Lipskiego, Warszawa 2012. 
Karolinska Institutet w Sztokholmie, a także asystując w pracy lekarzom kliniki uppsalskiej, w 1941 roku opublikował studium na temat mowy dziecięcej i afazji ${ }^{2}$. Rosyjskiego lingwistę afazja interesowała przede wszystkim jako zaburzenie językowe, które można było połączyć z mechanizmami działania metafory i metonimii ${ }^{3}$. Z jego koncepcji wyłaniała się wizja wypowiedzi literackiej jako swoistego komunikatu zaburzonego. Nie jest to jednak miejsce na omówienie związków między tezami Jakobsona a dynamicznie rozwijającymi się współcześnie studiami nad literaturą w kontekście choroby czy niepełnosprawności (choć związki te bez wątpienia istnieja). Obszar tych porównawczych badań jest bardzo rozległy i wciąż w niewielkim stopniu przebadany, co uświadamia między innymi lektura niedawno wydanego studium Chrisa Eagle'a o zaburzeniach mowy w kontekście literatury zachodniego modernizmu ${ }^{4}$. Wykorzystanie podobnego instrumentarium do analiz polskiej literatury wydaje się zadaniem wartościowym poznawczo, a także - w wypadku pisarstwa tak silnie eksponującego temat „rozpadu języka” jak proza Lipskiego - całkowicie uzasadnionym.

\section{Krótka historia afazji}

Na początek przejdźmy do kwestii znajdującej się do tej pory na drugim planie literaturoznawczych analiz twórczości Lipskiego - do jego choroby widzianej od strony studiów logopedycznych.

Korzeni afazjologii można się doszukiwać w starożytności ${ }^{5}$. Najstarsza informacja o tym zaburzeniu sięga XIV wieku p.n.e., gdy hetycki król Mursilis II został rażony w głowę piorunem i stracił zdolność mówienia i pisania. Pierwsze wzmianki dotyczące skutków uszkodzeń mózgu odnaleziono zaś w papirusie odkupionym przez egiptologa Edwina Smitha. Zawarto tam opis czterdziestu ośmiu przypadków, w tym dwudziestu siedmiu urazów głowy. Papirus ów uznaje się za pierwszy medyczny dokument $\mathrm{w}$ historii ludzkości, a jego autorem jest prawdopodobnie egipski lekarz, architekt i poeta - wezyr faraona Dżesera, Imhotep ${ }^{6}$. Bardziej

${ }^{2}$ Roman Jakobson, Kindersprache, Aphasie und allgemeine Lautgesetze, Uppsala 1941.

3 Idem, Two Aspects of Language and Two Types of Aphasic Disturbances, The Hague 1956, s. 55-82.

${ }^{4}$ Chris Eagle, Dysfluencies. On Speech Disorders in Modern Literature, London 2013.

${ }^{5}$ Historię afazji referuję na podstawie książek Jolanty Panasiuk, Afazja a interakcja. Tekst, metatekst, kontekst, Lublin 2013 i Marii Pąchalskiej, Afazjologia, Warszawa 2012.

${ }^{6}$ Jolanta Panasiuk, Afazja a interakcja..., op. cit., s. 26. 
szczegółowe dane na temat afazji można zaś odnaleźć w XVI wieku, gdy Johannes Schenck von Grafenberg opisał pacjenta z zaburzeniami mowy niezależnymi od motorycznej sprawności jego języka.

Wspomniany Chris Eagle, badający literaturę w kontekście zaburzeń mowy, w książce Dysfluencies. On Speech Disorders in Modern Literature wyznaczył symboliczny moment przejścia od tradycyjnej koncepcji języka - rozumianego jako duchowa właściwość wyróżniająca człowieka, zdolność dana mu od Boga - do jego nowoczesnego ujęcia: jako procesu biologicznego zachodzącego w mózgu. Co oczywiste, zmiana sposobu myślenia o języku nie mogłaby zaistnieć bez odkryć naukowych dokonanych w XIX wieku przez Paula Brokę i Carla Wernickego, pionierów afazjologii. Moment ten obrazują dwa świadectwa choroby powstałej na tle zaburzeń neurodegeneracyjnych: brytyjskiego pisarza i leksykografa Samuela Johnsona (który w 1783 roku doznał udaru i w tym samym roku opisał swoje doświadczenie) oraz francuskiego poety Charles'a Baudelaire'a (zachorował w roku 1866 i wtedy też tę chorobę opisał). Świadectwo Johnsona pochodzi jeszcze z czasów poprzedzających odkrycia kluczowe dla badań nad afazją, tymczasem przypadek Baudelaire'a jest symptomatyczny dla przełomu w analizowaniu omawianych zaburzeń mowy.

Brytyjczyka wyrwało ze snu nagłe wrażenie rozkojarzenia. W obawie przed utratą zdrowia psychicznego postanowił przetestować sprawność swojego umysłu: skomponował czterowersową modlitwę po łacinie. Pisanie przyszło mu łatwo, jednak gdy próbował ten wiersz przeczytać, okazało się, że nie jest w stanie tego zrobić - fakt ów uznał za przejaw nie szaleństwa, a paraliżu narządów mowy. Rano obudził się wciąż niezdolny do wypowiedzenia słowa, napisanie listu zaś sprawiło mu drobne trudności. Johnson tak opisał swoje objawy w liście do sąsiada:

Szanowny Panie, dzisiejszego poranka wszechmogący Pan Bóg pozbawił mnie władzy mówienia i, jako że nie wiem, czy nie spodoba $\mathrm{Mu}$ się wkrótce pozbawić mnie zmysłów, proszę, by po otrzymaniu tej wiadomości przyszedł Pan do mnie i działał w moim imieniu, na ile sytuacja będzie tego wymagać. Łączę wyrazy szacunku, S. Johnson, 17 czerwca $1783^{7}$.

${ }^{7}$ Macdonald Critchley, Letter 1, Chapman Collection, w: Dr Samuel Johnson's aphasia, „Medical History” 1962, nr 1, s. 29, cyt. za: Chris Eagle, Disfluencies..., op. cit., s. 2. 
Eagle uznaje ten list za ilustrację dominującego wówczas myślenia o języku: Johnson łączy utratę zdolności mówienia z paraliżem narządów mowy (czyli z motoryczną sprawnościa), a język uznaje za zdolność otrzymaną od Boga, którą ten może zarówno podarować, jak i odebrać.

Baudelaire - inaczej niż Johnson - władzę nad swoją mową tracił stopniowo. W 1866 roku zdiagnozowano u niego zapalenie opon mózgowych po lewej stronie mózgu, co było przyczyną prawostronnej hemiplegii (porażenia połowiczego) i afazji. Doznał prawdopodobnie nie jednego, a całej serii udarów, których rezultatem była prawie całkowita utrata mowy, współwystępująca $z$ aleksją i agrafią. Gdy afazja ustąpiła na tyle, że był w stanie zwerbalizować swoje doświadczenie, poeta podyktował lekarzowi list do swojej matki:

Nalegasz, bym odpowiedział ci od razu, powinnaś jednak wiedzieć, że napisanie mojego pełnego nazwiska stanowi teraz wielki wysiłek dla mojego mózgu ${ }^{8}$.

Na podstawie tego listu Eagle wyznaczył moment, w którym doszło do interakcji między historią badań nad zaburzeniami mowy a praktyką literacką. Z faktu, że Baudelaire określił napisanie własnego nazwiska jako wyzwanie dla mózgu, wynikałoby, że pacjent o jego pozycji i wykształceniu przyczyn tego typu językowych deficytów nie doszukiwał się już w paraliżu narządów mowy czy w zrządzeniu Boga, ale był świadom ich neurobiologicznego podłoża.

Nie działo się tak przez przypadek. Zaledwie pięć lat wcześniej, w 1861 roku, Paul Broca zaprezentował na posiedzeniu Paryskiego Towarzystwa Antropologicznego historię pacjenta $z$ zaburzeniami porozumiewania się powstałymi wskutek choroby neurologicznej. Pacjent Broki nazywał się Louis Victor Leborgne ${ }^{9}$, a do historii przeszedł pod imieniem TanTan - było to jedyne wyrażenie, które mężczyzna był w stanie wypowiedzieć (odpowiednio sprowokowany potrafił też wyrzucić z siebie parę przekleństw).

Trzydziestoletni Leborgne, choć utracił zdolność produkcji mowy, zachował zdolność jej rozumienia, co sygnalizował ruchami lewej ręki lub skinieniem głowy. Odkąd skończył czterdzieści lat, zaczęła się też u niego

${ }^{8}$ Yvan LeBrun, Janine Hasquin-Deleval, Jean Brihaye, Jacques Flament, L'apasie de Charles Baudelaire, „Revue Neurologique” 1971, nr 125, s. 310-316, cyt. za: Chris Eagle, Dysfluencies..., op. cit., s. 3.

${ }_{9}^{9}$ Jolanta Panasiuk, Afazja a interakcja..., op. cit., s. 27. 
rozwijać prawostronna hemiplegia - paraliż najpierw objął prawą rękę, a następnie prawą nogę. Ostatnie siedem lat życia mężczyzna poruszał się już tylko na wózku inwalidzkim. Gdy 17 kwietnia 1861 roku Leborgne zmarł, Broca od razu przeprowadził autopsję, która potwierdziła jego przypuszczenia - mózg pacjenta był uszkodzony w tylnej części drugiego i trzeciego zakrętu lewego płata czołowego. W ciągu następnych dwóch lat Broca przebadał dwadzieścia przypadków podobnych do przypadku Leborgne'a. W dziewiętnastu $z$ nich uszkodzenie mózgu znajdowało się w tylnej części lewego trzeciego zawoju czołowego. Obszar ten, odpowiedzialny za mowę artykułowaną, został nazwany ośrodkiem Broki. Wnioski francuskiego uczonego dotyczące mózgowej lokalizacji języka - choć były świadectwem refleksji pojawiającej się już wcześniej - okazały się przełomowe i przyczyniły się do ukształtowania współczesnego myślenia o języku, wedle którego rozpad języka jako systemu jest starannie odróżniany od fizycznej sprawności narządów mowy.

Trzeba jednak pamiętać, że badania Broki wyrastały z koncepcji lokalizacyjnych, czyli takich, w których konkretne funkcje umysłowe zostały powiązane $z$ konkretnym miejscem w mózgu. Pierwsze doniesienia kwestionujące tego typu założenia pojawiły się już w XIX wieku - teorie powstające $\mathrm{w}$ myśl koncepcji antylokalizacyjnych zakładały ${ }^{10}$, że każda funkcja, również mowa, ma hierarchiczne poziomy organizacji. W patologii może zostać uszkodzony jedynie poziom najwyższy, co oznacza, że uszkodzenie danego ośrodka nie musi powodować zniesienia danej funkcji umysłowej ${ }^{11}$.

Niedługo po tym, jak Broca opublikował swoje odkrycia na temat deficytów językowych spowodowanych uszkodzeniem w tylnej części lewego trzeciego zawoju czołowego, młody niemiecki neurolog Carl Wernicke ${ }^{12}$ zaczął prowadzić własne badania nad wpływem chorób i urazów mózgu na mowę i język. Jego pacjentka, kobieta o nazwisku Blanche, po udarze mówiła płynnie i stosowała się nawet do pewnych reguł gramatycznych, jednak jej mowa była pozbawiona sensu. Nie rozumiała ani tego, co do niej mówiono, ani tego, co mówiła ona sama. Sekcja mózgu pacjentki wskazała

${ }^{10}$ Ibidem, s. 67-70.

${ }^{11}$ Ibidem.

${ }^{12}$ Carl Wernicke jako pierwszy przedstawił też objawy, które mogłyby wyniknąć z zakrzepu tętnicy móżdżkowej dolnej tylnej, co potem potwierdził klinicznie Adolf Wallenberg. Na schorzenie, nazwane od nazwiska neurologa zespołem Wallenberga, cierpiał m.in. Aleksander Wat. 
na uszkodzenie w tylnej części pierwszego zakrętu płata skroniowego w lewej półkuli. Obszar ten nazwano ośrodkiem Wernickego.

Współcześnie wyodrębnia się liczne klasyfikacje i typologie zaburzeń mowy o podłożu neurologicznym, które prezentują odmienne perspektywy teoretyczne i metodologiczne. Według jednej z definicji afazji jest to zaburzenie:

[...] spowodowane organicznym uszkodzeniem pewnych struktur mózgowych (tzw. obszaru mowy leżącego w środkowej części półkuli dominującej - zwykle lewej u osób praworęcznych) częściowe lub całkowite zaburzenie mechanizmów programujących czynności nadawania i/lub odbioru mowy u człowieka, który uprzednio opanował te czynności ${ }^{13}$.

Objawy afatyczne można zorganizować w pięć głównych typów zaburzeń. Na tego typu obserwacji opiera się klasyfikacja pochodząca z 1935 roku, która - mimo że pominięte w niej zostały neuroanatomiczne korelacje objawów - wciąż jest często stosowana w praktyce klinicznej. W świetle tej klasyfikacji afazja Broki stała się prototypem dla afazji określanej jako ruchowa lub motoryczna, w której występują zaburzenia w tworzeniu wypowiedzi. Z kolei podstawą dla afazji czuciowej lub sensorycznej w których stwierdza się zaburzenia w rozumieniu wypowiedzi - jest afazja Wernickego. Do głównych typów zaburzeń uwzględnianych w tej klasyfikacji należą również: afazja mieszana (w której występują zarówno zaburzenia tworzenia wypowiedzi, jak i jej rozumienia), afazja nominacyjna (przejawiająca się trudnościami w użyciu nazw) oraz afazja całkowita (polegająca na zniesieniu zdolności do produkowania i odbierania wypowiedzi).

\section{Lipskiego „zamurowanie we własnym ciele”}

Przejdźmy teraz do Leo Lipskiego i jego twórczości. Zanim przyjrzymy się jego prozie z perspektywy studiów logopedycznych, trzeba zadać pytanie, na jaki typ zaburzeń pisarz cierpiał. Mam świadomość, że przy niedostępności jego rzetelnej i kompletnej dokumentacji medycznej próba odpowiedzi na to pytanie wiąże się miejscami z koniecznością formułowania domysłów na podstawie analizy i interpretacji rozmaitych świadectw, symptomów i przesłanek (wziętych także $z$ jego utworów).

${ }^{13}$ Jolanta Panasiuk, Afazja a interakcja..., op. cit., s. 23. 
Afazję, na którą zapadł Lipski, najpewniej można byłoby określić jako afazję ruchową (motoryczna), której pojęcie wyewoluowało ze wspominanej afazji Broki. Objawy, jakie miał pisarz, przypominały zarówno te dostrzeżone u Baudelaire’a, jak i u monsieur „Tan-Tan” Leborgne'a.

Przyszły autor Piotrusia wydostał się ze Związku Sowieckiego razem $z$ armią Andersa. W Bejrucie doznał nagłego paraliżu ${ }^{14}$. Zwiastunem choroby była wysoka gorączka, której przyczyn nie zdiagnozowano. W późniejszej fazie choroby Lipski cierpiał na porażenie połowicze (początkowo obejmujące tylko jego prawą rękę), czego ślady odnaleźć można w Piotrusiu, gdy mowa jest o "gumowej ręce" tytułowego bohatera ${ }^{15}$.

To właśnie w 1945 roku Lipski zamilkł na trzy lata ${ }^{16}$. Utracił zdolność posługiwania się nie tylko swoim ojczystym językiem, niemieckim, lecz także językami polskim i francuskim. Później w Piotrusiu pisał: „Język, którym myślę, rozpada się i kruszy. Jest niby-mamrotaniem starych kobiet, co moczą biszkopty w mleku. Gwałtowna atrofia: kurczę się"17. Słowa te są jednym $z$ wyjątkowych świadectw doświadczenia rozpadu języka. Pisarz odzyskał częściową sprawność, jednak już w wieku zaledwie dwudziestu ośmiu lat mógł się poruszać jedynie o lasce (potem na wózku inwalidzkim), a do końca życia pisał tylko lewą ręką, wystukując tekst na maszynie lub dyktując go. Wszystko to, co zapisywał ręcznie, było właściwie niemożliwe do odczytania. Zazwyczaj jest tak, że trudności, których chory na afazję doświadcza w mowie, występują w piśmie w postaci bardziej nasilonej i trwają dłużej. W przypadku Lipskiego czas trzyletniego milczenia to jednak okres intensywnej pracy nad pierwszą powieścią, Niespokojnymi, choć jej szkice zaczęły powstawać jeszcze przed wojną (czyli przed doświadczeniem dezintegracji systemu językowego).

Problem afazji w przypadku Lipskiego jest złożony również dlatego, że w wyniku neurologicznego incydentu pisarz utracił swój „język matczyny”

${ }^{14}$ Przez półtora roku leczył się w szpitalu Hadassa, potem w Tel Awiwie. Lekarzem Lipskiego przez parę początkowych lat jego choroby był Teofil Dawid Simchowicz, pierwowzór doktora Siegberta z Piotrusia, angażujący się w życie środowiska polskich uchodźców. Simchowicz był neurologiem, który w latach 1907-1910 pracował pod kierunkiem Alojza Alzheimera - $\mathrm{u}$ jego boku zajmował się otępieniem starczym. Zob. H. Gosk, Jesteś sam..., op. cit., s. 81.

${ }^{15}$ Leo Lipski, Piotruś, Paryż-Kraków 2015, s. 244.

${ }^{16}$ Leo Lipski, Życiorys, w: Materiaty korespondencja i hasta do "Stownika Emigracji”, hasło: Leo Lipski-Lipschuetz, Archiwum Instytutu Literackiego „Kultura”, ILK SE 01 Lipski, k. 1. Za informację tę dziękuję Piotrowi Sadzikowi.

${ }^{17}$ Leo Lipski, Piotruś, op. cit., s. 213. 
(niem. Muttersprache), którym był dla niego język niemiecki. Trzeba mieć na uwadze, że Leo Lipski (właśc. Leon Lipschütz) urodził się w 1917 roku w Zurychu i do szóstego roku życia niemiecki był dla niego jedynym językiem. Po ukończeniu sześciu lat, po przeprowadzce do Krakowa, prawdopodobnie zaczął się uczyć francuskiego i polskiego. Gdyby więc multilingwizm Lipskiego spróbować określić według kryterium czasu, w jakim nastąpiło przyswojenie drugiego języka, to należałoby go uznać za multilingwizm sukcesywny - a więc taki, w którym następne języki poznaje się po ukończeniu trzeciego roku życia.

Zdolność posługiwania się językiem francuskim, podobnie jak niemieckim, Lipski utracił w 1945 roku. Język polski był jego drugim lub trzecim językiem i tym, który został zachowany w największym stopniu. To na pozór zaskakujące zdarzenie można tłumaczyć złożonością zjawiska afazji u poliglotów, na co zwraca uwagę Panasiuk: „[...] w wyniku uszkodzenia mózgu najlepiej zachowany zostaje język, który nie tylko nie jest językiem ojczystym, ale też bywa rzadziej używany, a nawet jest przyswojony w mniejszym stopniu"18. I choć trudno jednoznacznie rozstrzygnąć, w jakim stopniu Lipski przyswoił te języki (zwłaszcza że dokumentacja przedwojennego życia pisarza jest jeszcze uboższa niż ta powojenna), to na utrzymanie lub szybszą restytucję któregoś z nich mogły wpłynąć również emocje związane z językiem później nabytym i prawdopodobnie gorzej przyswojonym - w tym wypadku z językiem polskim. Badania neurobiologiczne ${ }^{19}$ wykazują, że „[...] najlepiej zachowanym językiem w wypadkach afazji u poliglotów jest ten system, który jest emocjonalnie najbliższy choremu"20. Nie zawsze chodzi tu o język matki (jak w przypadku Lipskiego), rozstrzygające są często osobiste doświadczenia osoby dotkniętej afazją - pozytywne lub negatywne emocje kojarzone z użyciem danego języka. Prawidłowość ta okaże się istotna przy okazji analizy uporczywie powracających u Lipskiego zdań, a nawet całych fragmentów wypowiedzi.

Wszystko to, co uznaje się za jego dorobek literacki, Lipski napisał jako osoba, która prawdopodobnie bezpowrotnie utraciła zdolność posługiwania się swoim językiem ojczystym. W tym kontekście uprawnione mogłyby okazać się pytania o interferencje czy mieszanie się systemów

18 Jolanta Panasiuk, Afazja a interakcja..., op. cit., s. 638.

19 Ibidem, s. 639.

20 Ibidem. 
językowych znanych Lipskiemu. Przypadki podobnych zjawisk językowych zachodzą jednak częściej przy okazji multilingwizmu równoczesnego (nie sukcesywnego), czyli wtedy, gdy ktoś uczył się obu (lub kilku) systemów jednocześnie ${ }^{21}$. Niemniej w prozie Lipskiego $z$ całą pewnością można odnaleźć ślady zmagań $z$ wielojęzycznością. Pierwsze ślady pojawiają się już w drugim zdaniu Piotrusia: „Wtedy to właśnie byłem zmuszony okolicznościami i długami moralnymi wywiesić nad swoją głową wielki szyld w językach niemieckim, hebrajskim i angielskim: PIOTRUŚ WRAZ Z ODZIEŻA - DO SPRZEDANIA"22.

Lipski, jak przyznają osoby, które znały go osobiście, mówił niewyraźnie i bardzo niewiele. Sam akt pisania stał się więc, być może, jednym z niewielu dostępnych mu kanałów zaspokojenia potrzeby komunikacji. Agnieszka Maciejowska wspomina, że przez sześć lat znajomości z pisarzem usłyszała od niego może kilkanaście zrozumiałych zdań, a jego mowa była niewyraźna ${ }^{23}$. Autor Niespokojnych zmagał się prawdopodobnie $z$ dyspraksją, czyli zaburzeniem koordynacji i planowania ruchów; być może więc cierpiał również na zaburzenia kinestezji artykulacyjnej, co znacząco utrudniałoby mu komunikację. Zdaje się, że to ostatnie doświadczenie próbował zwerbalizować w Piotrusiu, kiedy pisał: „Idę po tragarza. Aha, zauważyłam, że pan sepleni i jąka się"24. Wbrew temu, co sugeruje tekst, pisarz zmagał się raczej nie z sygmatyzmem i jąkaniem, lecz prawdopodobnie właśnie $z$ dyspraksją i niepłynnością wynikającymi $z$ braku gotowości słownej. Objawiałyby się one trudnościami w przejściu od jednej informacji słownej do drugiej, co należy do charakterystycznych objawów klinicznych afazji.

Warto też zwrócić uwagę na wywiad, którego Lipski udzielił w 1996 roku. Dzięki temu, że zachowało się nagranie audiowizualne, wyraźnie widać, jakich trudności pisarz doświadczał na co dzień - choć objawy te musiały zaostrzyć się pod koniec życia (nagranie ledwo o rok poprzedza śmierć pisarza). Prawdopodobne jest również wystąpienie jeszcze jednego incydentu neurologicznego, w wyniku którego stan Lipskiego mógł się pogorszyć. Rozmowa (wydrukowana później w „Tekstach Drugich”) Stanisława Beresia z Leo Lipskim i Łucją Gliksman, która opiekowała się

21 Ibidem, s. 638.

22 Leo Lipski, Piotruś, op. cit., s. 201.

23 Agnieszka Maciejowska, Wstęp, w: Leo Lipski, Powrót, Paryż-Kraków 2015, s. 7.

24 Leo Lipski, Piotruś, op. cit., s. 203. 
pisarzem w Izraelu, liczy piętnaście stron. Lipski wypowiada się w niej trzynaście razy, większość jego wypowiedzi to zaprzeczenia lub potwierdzenia. Zdarzają się też zupełne niepowodzenia komunikacyjne, gdy Lipski próbuje coś powiedzieć, po czym głos zabiera Gliksman, która wypowiada się zamiast niego (nawet jeśli pytanie dotyczyło czasów, w których go jeszcze nie znała).

\section{Objawy zaburzenia a twórczość literacka}

Przejdźmy teraz do zagadnienia zawartego w tytule niniejszego artykułu: co wiedza na temat stanu zdrowia pisarza pozwala powiedzieć na temat jego twórczości? Jakie elementy, specyficzne dla jego pisarstwa, są lub mogą być powiązane z zaburzeniami, na które prawdopodobnie cierpiał?

$\mathrm{U}$ chorych po incydencie neurologicznym afazja na poziomie języka może przejawiać się na przykład w sposobie konstruowania zdań - trudności mogą sprawiać te zdania, których elementem konstytutywnym jest czasownik. W niektórych fragmentach prozy Lipskiego można dostrzec podobny mechanizm, choćby wtedy, gdy pisarz nominalnie zestawia nazwy przedmiotów i zdarzeń bez względu na to, jaka jest między nimi relacja: „Czarna burza stoi na zachodzie. Nieruchoma: coś z Golema. Cicha zawisła między wodą a niebem. Palce Ewy sypią iskry w oczekiwaniu, oczy jej są nieruchome. Cisza nakrywa ją jak dzwon"25. Zdania w utworach Lipskiego najczęściej są krótkie i mniej złożone, mniejsza jest również liczba zdań wtrąconych i zależnych: „W różnych kierunkach biegną ludzie. Nie widać twarzy. Kulą się. Bronią się przed mrozem. Jak bezbronni są. Trą sobie w biegu nos, policzki. Zatykają się szmatami. Tylko oczy, aby nie upaść" ${ }^{26}$. Dominacja prostych zdań pojedynczych widoczna jest także we fragmencie: „Przyjeżdża się z planami. Każda godzina jest droga. I tu dzieje się rzecz nieoczekiwana. Czas rozkłada się. Pomału, pomału wsiąka się w to wszystko. Ostrze tępieje. Dewastacja umysłu przez światło. Półrocze i lata. Porusza się jak w bagnie. Opada się"27.

Ingeborg Bachmann miała napisać do niemieckiej gazety „Die Zeit”28 recenzję Piotrusia. Tytuł tej powieści jest znamienny, ponieważ - zgodnie

${ }^{25}$ Idem, Niespokojni, w: idem, Powrót, op. cit., s. 68.

${ }^{26}$ Idem, Dzień $i$ noc, w: idem, Powrót, op. cit., s. 184.

27 Idem, Piotruś, op. cit., s. 216.

28 Adam Lipszyc, Czerwone listy. Eseje frankistowskie o literaturze polskiej, KrakówBudapeszt-Syrakuzy 2018, s. 69. 
z tym, co wykazały badania - osoby $z$ afazją mają tendencję do posługiwania się deminutywami ${ }^{29}$. I choć recenzji w końcu nie napisała, to zachowały się jej fragmenty, w których autorka zwraca uwagę między innymi na to, że Lipski nadużywa zaimków, które znacząco obniżają poziom precyzji jego prozy. Objawy te - mowa zaimkowa - również są charakterystyczne dla zaburzeń afatycznych. Łączy się z nimi także anomia czy pusta mowa. Przykładami ilustrującymi obecność tych objawów w twórczości pisarza są następujące fragmenty: „Ona ustawiła trzy leżaki obok siebie i rozmawiała z ożywieniem z tamtym”30; „Tam jest taki ścisk, że nie wiadomo, czyja ręka, czyja noga. [...]. Tam są rzeczy niebywałe” ${ }^{31}$; „[...] miałam spędzić noc, no, z jakimś” ${ }^{2}$; „- Jego się da do tego małego pokoju [...]. - Jeszcze by tam zdechł. Tu mięso się bardzo szybko psuje. - No to gdzie?"33.

Teksty narracyjne chorych $z$ afazją cechuje również rozpoczynanie narracji od przedstawienia wyjściowego stanu bohaterów opowiadania oraz redukcja tych elementów, które niosą ze sobą mniej konkretnych informacji; chodzi m.in. o streszczenia tego, co się dzieje, wnioski, podsumowania, znaki zakończenia tekstu, oceny zdarzeń. Wszystkie te objawy, charakterystyczne dla narracji afatyków, można znaleźć u Lipskiego. Za przykład weźmy początki poszczególnych rozdziałów Niespokojnych, które rozpoczynają się bez wprowadzenia czy też jakichkolwiek tekstowych sygnałów początku:

Joanna I

P. wyjechał i nie wiem, czy znajdzie się tak prędko ktoś, kto potrafi robić to tak jak on. Obiecał, że będzie przysyłał pieniądze co miesiąc. Twierdzi, że wraca za 3 mies. $[\ldots]^{34}$.

Obcy zapach

Emilowi otworzyła stara kucharka, którą nazywał Meduzą:

- O, panicz przyjechał! ${ }^{35}$.

${ }^{29}$ Jolanta Panasiuk, Afazja i interakcja..., op. cit., s. 99.

30 Leo Lipski, Piotruś, op. cit., s. 225.

31 Ibidem.

32 Ibidem, s. 240.

33 Ibidem, s. 205.

${ }^{34}$ Leo Lipski, Niespokojni, op. cit., s. 30.

35 Ibidem, s. 43. 
Jednym ze świadectw wzmożonej aktywności półkuli niedominującej jest $\mathrm{w}$ afazji poruszanie tematów obscenicznych. Zgodnie $z$ teorią antylokalizacyjna, w zaburzeniach mowy po uszkodzeniach mózgu dysfunkcyjny jest przede wszystkim poziom mowy intelektualnej, podczas gdy mówienie emocjonalne - bardziej zautomatyzowane i mimowolne, powiązane z prawą półkulą mózgu - może być na jakimś poziomie wciąż dostępne choremu $^{36}$. U Lipskiego widać to wyraźnie w szczerości i śmiałości opisów erotycznych. Jego pierwszej powieści, Niespokojnych, nie zdecydował się wydać Jerzy Giedroyć, obawiając się obyczajowego skandalu. Powieść ta ukazała się dopiero rok po śmierci Lipskiego, choć jej szkice powstały jeszcze przed wojną, a autor redagowal, poprawiał i uzupełniał ją do końca życia. Inny utwór, Piotruś, wzbudził nawet zainteresowanie wiedeńskiego parlamentu i austriackiego Ministerstwa Spraw Wewnętrznych (jego niemiecki przekład ukazał się w 1967 roku), a Lipskiego posądzono o pornografię. Podejmowanie tematów dotykających tabu fizjologii, płci, erotyzmu i seksualnego zaspokojenia (bardzo często w sposób wulgarny) powtarza się właściwie w całej twórczości pisarza ${ }^{37}$ (wyjątkiem może być Sarni braciszek, choć i tu pojawia się motyw klozetu - a opowiadanie liczy zaledwie dwie strony).

Najciekawsze efekty poznawcze zapewnia jednak przyjrzenie się pod kątem logopedycznym pewnym frazom i większym fragmentom, które, $\mathrm{w}$ różnych wariantach, powracają $\mathrm{w}$ prozie $\mathrm{i} \mathrm{w}$ listach pisarza. Jagoda Wierzejska zwróciła uwagę, że Lipski „,...] tylko nieznacznie modyfikował powtarzane motywy"38. Fakt ten stanowił dla niej przesłankę sugerującą

${ }^{36}$ Jolanta Panasiuk, Afazja a interakcja..., op. cit., s. 71.

37 Por. np. Leo Lipski, Niespokojni, op. cit., s. 120:

„Pewnego razu powiedział do niej:

- Kocham cię również dlatego, że jesteś w dziedzinie erotycznej - kimś.

Pewnego razu oglądała spermę na swoim brzuchu. Oglądała ją dokładnie. Potem powiedziała:

- Pokaż mi go.

Usiłował nie wziąć tego na serio.

- Musisz mi go pokazać.

Czuł się strasznie głupio, gdy ona uklękła między jego nogami i patrzyła tak, jak się ogląda preparat anatomiczny. Potem uniosła i oglądała jądra. Zamknął oczy ze wstydu.

- Komiczne - dodała - jak on się robi większy...”.

38 Jagoda Wierzejska, Retoryczna interpretacja autobiograficzna. Na przykładzie pisarstwa Andrzeja Bobkowskiego, Zygmunta Haupta i Leo Lipskiego, Warszawa 2012, s. 373 . 
„[...] zacieranie wątpliwej granicy oddzielającej utwory Lipskiego, które można by określić mianem niefikcjonalnych, od tych, które sytuują się na pograniczu fikcji i autobiografii”39. Powieściowy Emil wypowiada frazy zanotowane wcześniej przez Lipskiego $\mathrm{w}$ tak zwanych egotykach, czyli krótkich utworach pisanych prozą poetycką, uznawanych za teksty autobiograficzne. Podobne zjawisko można też zauważyć na przykładzie Piotrusia. Tym bardziej warto dodać, że intuicja Wierzejskiej mogłaby znaleźć potwierdzenie w badaniach nad afazją. Pisarska praktyka Lipskiego przypomina bowiem mechanizm działania perseweracji, czyli uporczywego powtarzania słów, zdań, a nawet całych fragmentów wypowiedzi. Perseweracje są często u chorego na afazję objawem mimowolnym, rodzajem nieuświadomionego déjà $v u$. Ten rodzaj powtarzania stanowi przejaw działania prawej półkuli, która reguluje zarówno procesy zautomatyzowane, jak i emocje.

W tym miejscu należy raz jeszcze zaznaczyć, że chorzy z głęboką afazją, dla których niemożliwe jest wypowiedzenie nawet jednego poprawnie sformułowanego zdania, są w stanie zrealizować np. przekleństwa, modlitwy, piosenki czy nawet całe teksty. Na jakość tego rodzaju produkcji ma wpływ także ich temat - te teksty, które poruszają daną osobę emocjonalnie albo odwołują się do jej osobistego doświadczenia, są realizowane lepiej i poprawniej. Dzieje się tak dlatego, że - jak już wspomniałam - sferą emocjonalną, tak jak automatyzmami, zawiaduje prawa półkula mózgu. Afatycy lepiej więc realizują treści dotyczące ich życia prywatnego lub bliskiego doświadczeniu. Zaburzenia pogłębiają się za to w przypadku tekstów, które nie angażują ich emocjonalnie. Jeśli weźmie się to pod uwagę, można na afazję spojrzeć nie tylko jak na wynik neurodegeneracyjnej utraty, lecz także jak na zjawisko specyficznego „przesunięcia się języka", który zostaje owładnięty przez prawą półkulę mózgu i powraca w nieznacznie zmienionych, uporczywych fragmentach. W afazji nie następuje bowiem zupełna utrata języka - można raczej mówić o ograniczeniu lub zniesieniu wiedzy o języku lub o utracie dostępu do niej.

Jeśliby odnieść przedstawione wyżej stwierdzenia do prozy Lipskiego, to należałoby wysnuć wniosek, że te fragmenty jego prozy, które powtarzają się i powracają nieznacznie tylko zmodyfikowane w całej jego twórczości, mogłyby być tekstami i frazami pobudzanymi przez najsilniejsze emocje lub tymi, które podlegają zautomatyzowaniu w takim stopniu,

${ }^{39}$ Ibidem, s. 374. 
w jakim zautomatyzowane mogą być słowa modlitwy. Oczywiście takie spostrzeżenie można by sformułować bez przytaczania terminologii logopedycznej, jednak odwołanie się w tym miejscu do zjawiska perseweracji, potraktowanego bardziej metaforycznie i odniesionego do literaturoznawstwa, pozwala uświadomić coś więcej. Otóż można podejrzewać, że powtarzające się fragmenty i frazy u Lipskiego - właśnie dlatego, że zautomatyzowane - pojawiają się w postaci nieprzetworzonej językowo i nieprzepuszczonej przez filtr świadomości pamięciowej, która modeluje wypowiedź. Podkreślmy zatem, byłyby to fragmenty w najmniejszym stopniu „wymyślone” i skonwencjonalizowane, w największym zaś związane z biografią pisarza.

Mowa tu na przykład o najbardziej znanym fragmencie prozy Lipskiego - zakończeniu Piotrusia, które pisarz zapisał dwukrotnie w nieznacznie zmienionym kontekście. W egotyku czytamy:

[...] przy mnie: „On nic nie słyszy, biedny. On nic nie rozumie, co się do niego mówi. On jest nieprzytomny". Mówiła to Lotka, Witek, Niusia i ja to wszystko słyszałem i rozumiałem ${ }^{40}$.

W liście do Michała Chmielowca (1947) Lipski pisze:

Grozi mi poza tym zamurowanie we własnym ciele. Wobec tego stan, w którym Niusia mówiła: - On nie widzi - a ja widziałem, Anka mówiła: On nie słyszy - a ja słyszałem, Inka mówiła: - On nie rozumie, co się do niego mówi, a ja rozumiałem - tylko nie mogłem mówić - wydaje się doskonały $^{41}$.

Z kolei w zakończeniu Piotrusia fragment ten powraca w delikatnie zmienionej formie:

Czy warto ryzykować życie dla wielu lat konania? Znałem to już. „On nic nie słyszy, biedny. On nie rozumie, co się do niego mówi. On jest nieprzytomny" - mówiła Anka, Lotka. A ja wszystko słyszałem i rozumiałem doskonale. To będzie gorsze. Konanie, w milczeniu, przez lata. Zamurowany we własnym ciele (jak mniszki zamurowywano) ${ }^{42}$.

40 Leo Lipski, Paryż ze złota, Izabelin 2002, s. 77.

41 List Leo Lipskiego do Michała Chmielowca z pierwszej połowy 1947 roku (Archiwum Emigracji), cyt. za: Agnieszka Maciejowska, Wstęp, w: Leo Lipski, Powrót, op. cit., s. 11 .

${ }^{42}$ Leo Lipski, Piotruś, op. cit., s. 256. 
Podobnie dzieje się z innym znanym fragmentem zakończenia, który, zanim pojawił się w Piotrusiu, został zanotowany w egotyku i w krótkim utworze - jak pisze Wierzejska - z pogranicza liryki i prozy:

[Moje stanowisko]

[...] Cofam się w głąb samego siebie, pozostawiając fasadę, która się śmieje i mówi; ale mnie tam nie $\mathrm{ma}^{43}$.

[Joga]

[...] W końcu cofniesz się w głąb samego siebie, zostawiając fasadę mówiącą, śmiejącą się. Wtedy wejdą zwierzęta do twego pokoju i siądą na tobie spokojnie, jak na kamieniu i ziemi ${ }^{44}$.

[Fragment Piotrusia:]

Czy warto ryzykować życie dla wielu lat konania? [...] I wtedy wejdą zwierzęta do twojego pokoju i siądą na tobie spokojnie, jak na kamieniu i ziemi ${ }^{45}$.

A oto jeszcze inny fragment, który pojawił się w Piotrusiu, a oprócz tego aż czterokrotnie powraca w nieznacznie zmienionych wariantach: w dwóch trochę różniących się egotykach, fragmencie prozy (autobiograficznej notatki) oraz w nawiązaniu do Niespokojnych:

[Nowe egotyki]

$[\ldots]$

Ludzie odpadają ode mnie, jak liście $z$ więdnącego drzewa.

Samotność krąży nade mną; jak ptak, jak wiatr, jak burza ${ }^{46}$.

[Joga]

Pustka będzie krążyła nad twoją głową, jak dziki ptak, jak wiatr, jak burza ${ }^{47}$. [Fragment prozy, autobiograficznej notatki]

[...] Przed laty mówiłem: Odpadają ode mnie ludzie jak liście z więdnącego drzewa. I Ireny: ... jak na pustyni będziesz ${ }^{48}$.

${ }^{43}$ Leo Lipski, [Moje stanowisko], w: idem, Paryż ze złota, op. cit., s. 47.

44 Ibidem, s. 48.

45 Leo Lipski, Piotruś, op. cit., s. 256.

${ }^{46}$ Leo Lipski, [Nowe egotyki], w: idem, Paryż ze złota, op. cit., s. 53.

47 Ibidem, s. 48.

48 Ibidem, s. 79. 
[Piotruś]

Życie osiada na twarzy jak pył. Ludzie odpadli ode mnie. Tynk. Liście jesienią. Oplątany jestem snem, dzikim winem ${ }^{49}$.

[Nawiązanie do Niespokojnych]

Ludzie odpadają ode mnie jak liście. Samotność krąży nade mną jak ptak, jak wiatr, jak burza, jak... Dość ${ }^{50}$.

\section{Do źródeł literatury Lipskiego}

W świetle przedstawionych rozpoznań, wspartych wiedzą logopedyczną, narzuca się stricte już literaturoznawcze pytanie: w jakim stopniu objawy, które były doświadczeniem Lipskiego, kształtowały jego prozę literacką? Trudno jednoznacznie rozstrzygnąć, czy (i w jakim stopniu) autor nadawał swoim tekstom formę odzwierciedlającą znane mu $z$ autopsji objawy neurologiczne (a więc czy formę tę nadawał im wtórnie), czy też (i w jakim stopniu) po prostu inaczej nie był w stanie funkcjonować i tworzyć. Czy wpisywał $\mathrm{w}$ tekst pamięć trzech lat zupełnego milczenia i (być może) żmudnego odpominania języka polskiego, czy raczej był sukcesywnie wykorzeniany z języka i to doświadczenie znajdowało wyraz w jego prozie?

Niezależnie od tych niełatwych do jednoznacznego rozstrzygnięcia kwestii wyłaniają się zagadnienia ogólniejsze, które zasadnie można w tym kontekście rozpatrywać. Chodzi mianowicie o związki choroby $\mathrm{z}$ pisarstwem, o relacje między rzeczywistym i uwiarygodnionym $\mathrm{w}$ prozie cierpieniem autora a jego wyobraźnią twórczą. Moim celem nie było, rzecz jasna, dokonanie deterministycznej redukcji poprzez opisanie twórczości Lipskiego jako przejawu jego choroby. Zależało mi natomiast na naświetleniu $z$ medycznego punktu widzenia tego, co wydaje się $\mathrm{w}$ jego utworach najbardziej osobne, niepowtarzalne i - chciałoby się powiedzieć - „literackie”. Okazuje się, że to, co stanowi o ich specyfice, bez wątpienia wiąże się właśnie z jego biograficznym doświadczeniem choroby i zarazem niewiele ma wspólnego ze stereotypowymi konotacjami pojęcia fikcji - czy to utożsamianej ze zmyśleniem (kreowaniem, fantazjowaniem itd.), czy to z posługiwaniem się rozmaitymi konwencjami. Lipski, jak w znanej formule Witolda Gombrowicza przywoływanej przez Ryszarda Nycza, „pisze sobą, z siebie”.

49 Leo Lipski, Piotruś, op. cit., s. 212.

${ }^{50}$ Leo Lipski, [Nawiązanie do „Niespokojnych”], w: idem, Powrót, op. cit., s. 97. 
Autor Piotrusia w pewnym sensie zapobiega ostatecznemu rozpadowi języka - a te fragmenty, obrazy i frazy, które udaje mu się ocalić przed niewysłowieniem, stają się bodaj właściwym źródłem jego literatury. Otwarte pozostaje tym samym pytanie o to, jaką koncepcję literatury można by zbudować na przykładzie twórczości Lipskiego, a także o to, czego o literaturze i jej źródłach możemy się dowiedzieć dzięki temu pisarzowi.

\section{Bibliografia}

Błahy J., Literatura jako lustro. O projekcji i odbiciach fizjologicznych $w$ twórczości Leo Lipskiego, Wydawnictwo Forma, Szczecin 2009.

Eagle Ch., Dysfluencies. On Speech Disorders in Modern Literature, Bloomsbury, London 2013.

Gosk H., Jesteś sam w swojej drodze, Świat Literacki, Izabelin 1998.

Jakobson R., Kindersprache, Aphasie und allgemeine Lautgesetze, Uppsala 1941; przekł.

ang.: Child Language. Aphasia and Phonological Universals, przel. A.R. Keiler, The Hague 1968.

Jakobson R., Two Aspects of Language and Two Types of Aphasic Disturbances,

w: R. Jakobson, M. Halle, Fundamentals of Language, The Hague 1956, s. 55-82;

przekł. pol.: Dwa aspekty języka i dwa typy zakłóceń afatycznych, w: eidem, Podstawy jezzyka, przeł. L. Zawadowski, Zakład Narodowy im. Ossolińskich, Wrocław 1974. Lipski L., Dzień i noc, w: A. Maciejowska (red.), Powrót, Instytut Literacki „Kultura”Instytut Książki, Paryż-Kraków 2015.

Lipski L., Niespokojni, w: A. Maciejowska (red.), Powrót, Instytut Literacki „Kultura”Instytut Książki, Paryż-Kraków 2015.

Lipski L., Paryż ze złota, red. H. Gosk, Świat Literacki, Izabelin 2002.

Lipski L., Piotruś, w: A. Maciejowska (red.), Powrót, Instytut Literacki „Kultura”Instytut Książki, Paryż-Kraków 2015.

Lipszyc A., Czerwone listy. Eseje frankistowskie o literaturze polskiej, Wydawnictwo Austeria, Kraków-Budapeszt-Syrakuzy 2018.

Lipszyc A., Zamurowani: Schulz, Lipski, Hering, w: J. Olejniczak (red.), Przed i po. Bruno Schulz, Wydawnictwo Pasaże, Warszawa 2018.

Maciejowska A., Wstęp, w: Powrót, red. A. Maciejowska, Instytut Literacki „Kultura”Instytut Książki Paryż-Kraków 2015.

Panasiuk J., Afazja a interakcja. Tekst, metatekst, intertekst, Wydawnictwo Uniwersytetu Marii Curie-Skłodowskiej, Lublin 2013.

Pąchalska M., Afazjologia, Wydawnictwo Naukowe PWN, Warszawa 2012.

Wierzejska J., Retoryczna interpretacja autobiograficzna. Na przykładzie pisarstwa Andrzeja Bobkowskiego, Zygmunta Haupta i Leo Lipskiego, Dom Wydawniczy ELIPSA, Warszawa 2012. 


\section{A B S T R A C T}

\section{"I understood, only I could not speak". About Leo Lipski's aphasia. Reconnaissance}

The article analyzes the work of Leo Lipski, who is known to have suffered speech disorders of a neurological background, from the perspective of speech therapy. As a context, which is crucial to understand the writer's disease, the history of aphasic studies has been presented. The authoress also refers to Chris Eagle's Dysfluencies. On Speech Disorders in Modern Literature (2013), a study on speech disorders in the literature of Western Modernism. The symptoms of Lipski's disease recorded in memoirs, audiovisual recordings and his literary works - have been discussed in the light of contemporary knowledge about various kinds of aphasic disorders. In the next part of the article, the authoress has tried to relate the particularity and uniqueness of Lipski's literary work to his health disorders, and asked the question how the experience of suffering from neurological diseases is represented in his prose and how it becomes a subject thereof. Finally, the attention is drawn to the way in which speech therapy knowledge could be used as a tool for literary studies in general.

KEY WORDS: aphasia, speech disorders, speech therapy, medicine, perseveration

\section{A B S T R A K T}

\section{„Ja rozumiałem, tylko nie mogłem mówić”. O twórczości Leo Lipskiego jako afatyka. Rekonesans}

Autorka przeprowadziła analizę twórczości Leo Lipskiego - który cierpiał na zaburzenia mowy o podłożu neurologicznym - z perspektywy współczesnej wiedzy logopedycznej. Jako kontekst - niezbędny do zrozumienia choroby pisarza - przedstawiła historię studiów afazjologicznych. Wsparciem dla przeprowadzonych analiz jest też książka Chrisa Eagle'a Dysfluencies. On Speech Disorders in Modern Literature (2013) o zaburzeniach mowy w literaturze zachodniego modernizmu. Zarejestrowane we wspomnieniach, nagraniach audiowizualnych i prozie artystycznej symptomy choroby pisarza omówiła w kontekście współczesnej wiedzy o różnego rodzaju zaburzeniach afatycznych. W następnej części artykułu podjęła rozważania na temat oryginalnych cech twórczości Lipskiego, które można powiązać z jego zaburzeniami, oraz tego, w jaki sposób doświadczenie choroby jest tematyzowane i reprezentowane w jego prozie. Na koniec podjęła też refleksję nad tym, czy wiedza logopedyczna może stać się operatywnym narzędziem dla literaturoznawstwa.

SŁOWA KLUCZOWE: afazja, zaburzenia mowy, logopedia, medycyna, perseweracja 
Agnieszka Więckiewicz

Uniwersytet Warszawski

\section{Śmierć ojca i narodziny matki - wzajemna analiza w „Dzienniku klinicznym” Sándora Ferencziego}

W dzienniku pod datą 24 lutego 1932 roku Sándor Ferenczi zapisał:

[...] możliwe, że u źródeł wzajemna analiza, jako symptom paranoicznej nieufności, była wynalazkiem pacjentów. Trzeba zaznaczyć, że nie bez przyczyny wyczuwają oni $u$ analityka rozmaite zahamowania wynikające $z$ jego niechęci do analizowanych, do czego on sam nie chce się przed sobą przyznać ${ }^{1}$.

Na koncepcję wzajemnej analizy ${ }^{2}$ naprowadziły węgierskiego psychoanalityka jego pacjentki - R.N., B., S.I. i D.M. Szczególną rolę w kształtowaniu rewelatorskiej metody psychoanalitycznej odegrała Elisabeth Severn, w dzienniku występująca pod pseudonimem R.N. Odwołując się do ich rozmowy, lekarz notował:

Pacjentka mówi mi, nie skrywając pesymizmu: „Analityk nigdy nie będzie w stanie doświadczyć tego, co mnie spotkało, w taki sposób, jak ja to odczuwam. Dlatego nie może on podążać za "psychofizyką" mojego intelektu i partycypować w moim przeżyciu”. Odpowiadam jej na to: „Chyba że wraz z pacjentką dostanę się do jej nieświadomości dzięki moim własnym kompleksom i traumom". Pacjentka zgadza się z tym, jednak nie ukrywa wątpliwości wobec tego typu „mistycznej” procedury33.

1 Sándor Ferenczi, Journal clinique [„Dziennik kliniczny”], Paris 1985, s. 113.

${ }^{2} \mathrm{~W}$ dzienniku na określenie nowej metody pracy z pacjentkami Ferenczi wprowadził termin mutuelle Analyse, który proponuję tłumaczyć jako „wzajemną analizę”.

3 Sándor Ferenczi, Journal clinique, op. cit., s. 106. 
W ujęciu Ferencziego wzajemna analiza miała prowadzić do zmniejszenia dystansu między psychoanalitykiem a pacjentką, między innymi wskutek odrzucenia kategorii, takich jak ,,normalny” bądź „,nienormalny" . Dzięki temu lekarz i analizowana, znalazłszy się na równej pozycji, mogli przyglądać się własnemu doświadczeniu z perspektywy drugiego ${ }^{5}$. Późna refleksja Ferencziego nad bliską relacją pacjent-lekarz okazuje się zbieżna z założeniami koncepcji medycyny narracyjnej w ujęciu Rity Charon, która zaakcentowała konieczność dowartościowania opowieści pacjentów oraz nadała szczególne znaczenie ich własnym narracjom dotyczącym doświadczenia choroby. W dalszej perspektywie to nowatorskie podejście w opiece medycznej przywracać ma (chociażby w założeniu) osobom leczonym w umasowionym systemie medycznym status podmiotów. Korzeni radykalnego pomysłu wyzwolenia chorego spod władzy i autorytetu lekarza (analityk traci wyłączne prawo do interpretowania słów pacjenta) szukać można w psychoanalizie, przede wszystkim zaś w jej wersji Ferencziańskiej. To pozwala spojrzeć na teorię węgierskiego lekarza jako na jedno ze źródeł medycyny narracyjnej ${ }^{6}$.

W Journal clinique („Dzienniku klinicznym”) obok koncepcji pełnej otwartości i szczerej empatii analityka wobec pacjentów pojawiła się też ostra krytyka podstawowych założeń teorii psychoanalitycznej - rozumienia traumy, kompleksu Edypa oraz autoanalizy ${ }^{7}$. Nowatorskie rozpoznania Ferencziego nie zostały przyjęte przez międzynarodowe środowisko psychoanalityczne, a wrogość samego Sigmunda Freuda wywarła bezpośredni wpływ na fakt ,wymazania” go z historii freudyzmu na ponad pół wieku ${ }^{8}$. $\mathrm{Na}$ gruncie polskim teoria Sándora Ferencziego, podobnie jak historia rozwoju psychoanalizy na Węgrzech, ciągle jest mało znana ${ }^{9}$. Do lat 80 .

4 Ibidem, s. 63-67.

${ }^{5}$ Ibidem, s. 133-136.

${ }^{6}$ O źródłach koncepcji narrative medicine oraz ich związku z psychoanalizą - zob. Peter L. Rudnytsky, Rita Charon (red.), Psychoanalysis and Narrative Medicine, New York 2008. Co istotne, Rudnytsky, obok André Haynala, jest dziś jednym z najważniejszych interpretatorów teorii Ferencziego - por. Peter L. Rudnytsky, Reading Psychoanalysis. Freud, Rank, Ferenczi, Groddeck, New York-London 2002; idem, Rescuing Psychoanalysis from Freud and Other Essays in Re-vision, London 2011.

7 Ibidem, s. 88, 160-163, 317-319.

8 Por. Michael Balint, Introduction, w: Sándor Ferenczi, Journal clinique, op. cit., s. 24-32.

${ }^{9}$ O Sándorze Ferenczim w kontekście Eugenii Sokolnickiej wspomina Lena Magnone - zob. Lena Magnone, Emisariusze Freuda. Transfer psychoanalizy do polskich sfer 
XX wieku większość prac analityka z zakresu intymistyki pozostawała w rękopisach. Wydanie Journal clinique, listów do Georga Groddecka oraz najdłużej wyczekiwanej korespondencji z Freudem pozwoliło przywrócić mu należną pozycję w historii myśli psychoanalitycznej.

\section{Najwierniejszy freudysta. Psychoanaliza na Węgrzech}

Ferenczi pochodził z rodziny polskich Żydów, którzy w latach 40. XIX wieku wyemigrowali z Galicji na Węgry. W młodości rodzice psychoanalityka, Baruch Fränkel i Rosa Eibenschütz, mieszkali w Krakowie i oprócz jidysz posługiwali się językami polskim i niemieckim, później zaś węgierskim. Przyszły psychoanalityk urodził się w 1873 roku w Miszkolcu, niewielkim mieście oddalonym o trzysta kilometrów od Krakowa, gdzie jego ojciec prowadził dobrze prosperującą księgarnię. W 1893 roku, pięć lat po jego śmierci, przyszły psychoanalityk przeniósł się do Wiednia w celu odbycia studiów medycznych. Po uzyskaniu dyplomu Uniwersytetu Medycznego wyjechał do Budapesztu i od 1897 roku praktykował w Szent Rókus Kórház (Szpitalu św. Rokusa), a następnie w Szent Erzsébet Kórház (Szpitalu św. Elżbiety), gdzie leczył tzw. trudnych pacjentów wywodzących się z najniższych warstw społecznych.

Pod koniec XIX wieku lekarz interesował się spirytyzmem, telepatią i wzorował się na pracach Pierre'a Janeta oraz Charlesa Richeta. Dopiero po 1900 roku w jego badaniach pojawił się temat histerii oraz teoria Freudowska. Istotną rolę w zwrocie Ferencziego ku psychoanalizie odegrał Carl Gustav Jung, którego praca Diagnostische Assoziationsstudien. Beiträge zur experimentellen Psychopathologie wywarła pozytywne wrażenie na młodym analityku. $Z$ polecenia szwajcarskiego lekarza spotkał się on z Freudem w 1908 roku. Zaledwie kilka miesięcy później autor Objaśniania marzeń sennych zgłosił jego kandydaturę do Środowego Towarzystwa Psychologicznego, co spotkało się z jednogłośną akceptacją wszystkich członków. Wakacje tego samego roku młody lekarz spędził w towarzystwie rodziny Freuda w Berchtesgaden, co bezpośrednio wpłynęło na zacieśnienie ich wzajemnej więzi. Prowadzona od tego momentu korespondencja

inteligenckich przed druga wojna światowa, Kraków 2016, s. 32-41. O węgierskiej psychoanalizie oraz historii jej twórcy piszę więcej w artykule: Agnieszka Więckiewicz, Rewolucjoniśsi i pariasi. Historia narodzin $i$ zmierzchu węgierskiej psychoanalizy, Kraków 2018. 
funkcjonowała nie tylko jako przestrzeń wymiany myśli, lecz także służyła praktykowaniu autoanalizy przez początkującego psychoanalityka.

Bez wątpienia Ferenczi był pierwszym i najważniejszym emisariuszem freudyzmu na Węgrzech, popularyzowanego przez niego już od 1908 roku. $\mathrm{Z}$ początku bardziej niż $\mathrm{w}$ środowiskach medycznych psychoanaliza znalazła oddźwięk wśród pisarzy i krytyków literackich współtworzących czasopismo „Nuygat” (,Zachód”), powstałe w tym samym roku. Razem z węgierskimi modernistami, takimi jak: Dezsö Kosztolányi, Frigyes Karinthy, Mihály Babits, Milán Füst czy Géza Csáth, Ferenczi podejmował kwestie związków psychoanalizy z literaturą ${ }^{10}$. Kosztolányi, Ignotus oraz Gyula Krudy regularnie spotykali się w mieszkaniu Ferencziego, aby przysłuchiwać się kameralnym wykładom poświęconym najnowszym odkryciom Freuda. Stosunkowo niewielka popularność psychoanalizy $\mathrm{w}$ budapeszteńskich sferach inteligenckich $\mathrm{w}$ pierwszym dziesięcioleciu XX wieku zniechęciła Freuda do dalszych prób rozszerzenia współpracy z tamtejszymi środowiskami medycznymi. Sytuacja uległa odwróceniu po pierwszej wojnie światowej, w wyniku której zmienił się nie tylko system polityczny, lecz także stosunek do psychoanalizy.

W okresie 1918-1919, na który przypadły rządy sowieckie, freudyzm cieszył się rosnącym uznaniem. Zaraz po zakończeniu Wielkiej Wojny w Budapeszcie, pod przewodnictwem Ferencziego, zorganizowano V Międzynarodowy Kongres Psychoanalityczny, poświęcony traumom wojennym $^{11}$. Pozytywne przyjęcie przez rząd węgierski efektów badań nad psychicznymi skutkami doświadczenia wojny oraz osłabienie pozycji Wiednia po rozpadzie Austro-Węgier skłoniły Freuda do przemyślenia możliwości przeniesienia głównej siedziby Międzynarodowego Towarzystwa Psychoanalitycznego do Budapesztu. W 1919 roku Ferenczi uzyskał tytuł profesora i objął pierwszą katedrę psychoanalizy na Uniwersytecie Medycznym w Budapeszcie. W przeciągu zaledwie dziesięciu lat freudyzm odniósł na Węgrzech większe sukcesy niż w innych krajach. Niestety, jego błyskotliwa kariera została przerwana wskutek dojścia do władzy skrajnej prawicy i rządów Miklósa Horthyego. Szerzący się antysemityzm doprowadził do wykluczenia naukowców, lekarzy, artystów i pisarzy pochodzenia żydowskiego z życia publicznego. Ferenczi stracił posadę

10 Zob. Cure d'ennui. Écrivains hongrois autour Sándor Ferenczi, Paris 1992.

11 Zob. Sigmund Freud, Sándor Ferenczi, Karl Abraham, Ernst Simmel, Ernest Jones, Zur Psychoanalyse der Kriegsneurosen, Wien-Leipzig 1919. 
uniwersytecką i członkostwo w Węgierskim Towarzystwie Medycznym, a sama psychoanaliza przestała być uznawana za jedną z dyscyplin akademickich. W związku z gwałtowanymi zmianami politycznymi na Węgrzech najważniejszym ośrodkiem rozwoju freudyzmu w latach 20. XX wieku nie był już Budapeszt, lecz Berlin.

Jak zauważył André Haynal, po 1920 roku publiczna kariera Ferencziego została zakończona, on sam zaś poświęcił się prywatnej praktyce oraz skoncentrował na publikowaniu w wydawnictwach psychoanalitycznych założonych przez Freuda ${ }^{12}$. Pierwszym wydanym dziełem węgierskiego lekarza był traktat Thalassa. Versuch einer Genitaltheorie ${ }^{13}$, którego inspiracje pochodziły $z$ antropologii, literatury oraz biologii. Praca została utrzymana w „duchu freudowskim” - aktywny charakter męskiej seksualności przeciwstawiono w niej pasywności kobiecej. W późniejszych tekstach oraz w „Dzienniku klinicznym” Ferenczi odwrócił się od swych wcześniejszych rozpoznań i przeprowadził feministyczną z ducha krytykę własnego dzieła oraz całej freudowskiej teorii seksualnej ${ }^{14}$. W tym samym roku wraz z Ottonem Rankiem analityk wydał kolejną rozprawę pod tytułem Entwicklungsziele der Psychoanalyse. Zur Wechselbeziehung von Theorie und Praxis $^{15}$, poświęconą związkom teorii i praktyki w psychoanalizie. Kolejne lata oprócz odczytów i artykułów nie przyniosły obszerniejszych publikacji. Z biegiem czasu Ferenczi stopniowo odsunął się od środowiska Freuda na rzecz tworzenia budapeszteńskiej szkoły psychoanalitycznej ${ }^{16}$.

\section{Teoria i klinika w dzienniku badawczym}

Pod koniec życia Ferenczi rozpoczął prowadzenie dziennika, w którym wiele miejsca poświęcił szczegółom $\mathrm{z}$ analiz swych pacjentek ${ }^{17} . \mathrm{Z}$ tego powodu „Dziennik kliniczny” stanowi niezastąpione źródło wiedzy o jego nowatorskiej teorii psychoanalitycznej. Najważniejszy element późnego systemu teoretycznego węgierskiego lekarza stanowiła koncepcja

${ }^{12}$ Zob. André Haynal, Introduction, w: Sigmund Freud, Sándor Ferenczi, Correspondance, t. 3: 1920-1933, Paris 2000.

${ }_{13}$ Sándor Ferenczi, Thalassa. Versuch einer Genitaltheorie, Wien-Leipzig-Zurich 1924.

${ }^{14}$ Idem, Journal clinique, op. cit., s. 250.

${ }^{15}$ Idem, Otto Rank, Entwicklungsziele der Psychoanalyse. Zur Wechselbeziehung von Theorie und Praxis, Wien-Leipzig-Zurich 1924.

${ }^{16}$ Por. Judit Mészáros, The Tragic Success of European Psychoanalysis. The Budapest School, „International Forum of Psychoanalysis” 1998, s. 207-214.

17 Dziennik obejmował okres od 7 stycznia do 2 października 1932 roku. 


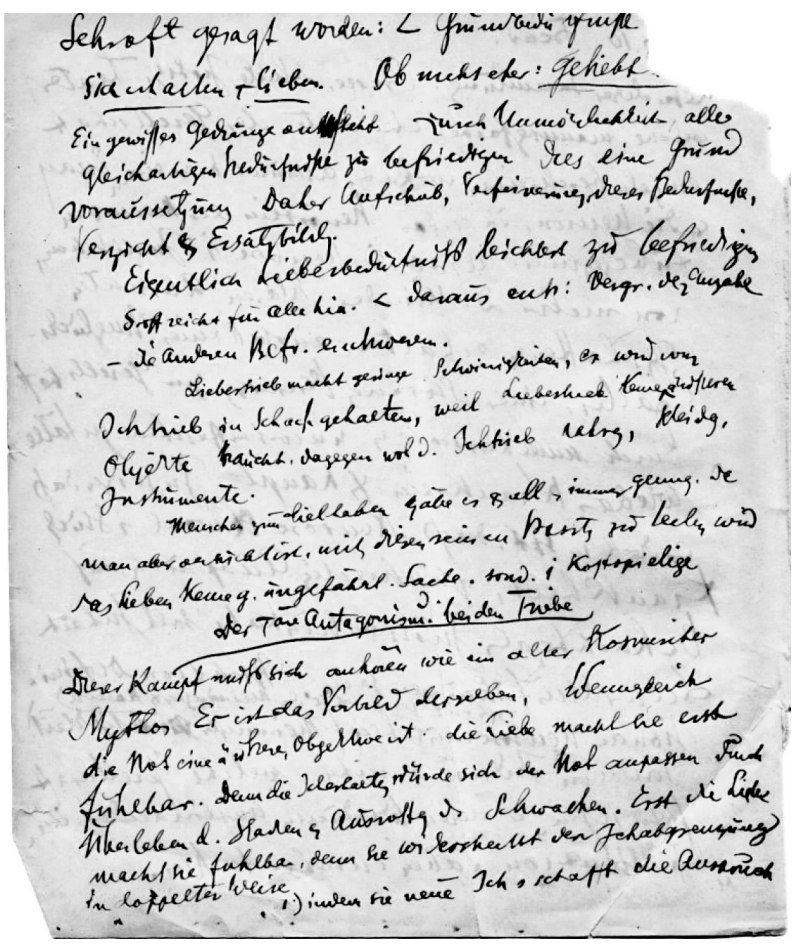

Rycina 1. „Dziennik kliniczny” (rękopis), Sándor Ferenczi Archive, Freud Museum London

wzajemnej analizy - rewelatorskiej techniki, której celem było krytyczne zmierzenie się z najważniejszymi założeniami Freuda oraz poprawienie wydajności metod pracy z pacjentami. W przypadku dzienników badawczych czytelnicy mają do czynienia $z$ tekstem, w którym analiza naukowa ściśle łączy się z refleksją autobiograficzną. W tym sensie tekst naukowy zawarty w dzienniku nigdy nie będzie w pełni obiektywny. Chociaż punktem wyjścia jest dla niego myśl teoretyczna, to ostatecznie przedmiotem naukowej analizy staje się podmiot piszący. W tym punkcie zapis autobiograficzny najściślej wiąże się z psychoanalizą, bowiem dla obu warunkiem sine qua non jest autoanaliza ${ }^{18}$. Jak zauważyła Brigitte Galtier, nierozerwalna więź subiektywnego z obiektywnym - jako podstawowa

18 Por. Didier Anzieu, L'auto-analyse de Freud et la découverte de la psychanalyse, Paris 1988. 
cecha tego typu dzienników - wcale nie przeszkadza w traktowaniu ich jako pełnoprawnego źródła wiedzy ${ }^{19}$.

„Dziennik kliniczny” nie miał jednego autora; jego treść bazowała na rozmowach z pacjentkami, mającymi wpływ na charakter i formę poszczególnych wpisów, z których znaczna część została podyktowana przez analityka jednej $z$ jego współpracownic. Dlatego, inaczej niż w przypadku większości notatników intymnych, „Dziennik kliniczny” Ferencziego nie był efektem codziennych praktyk piśmiennych (ręcznie zapisana została jedynie 1/5 dziennika), lecz czasu spędzonego $z$ analizowanymi oraz z sekretarką, spisującą na maszynie dyktowane słowa ${ }^{20}$. Dziennik nie był też tekstem „sekretnym” - o jego istnieniu wiedzieli najbliżsi współpracownicy i rodzina węgierskiego lekarza: Gizela Ferenczi, Michael i Alice Balint oraz Vilma Kovács ${ }^{21}$.

W 1933 roku, po śmierci Ferencziego jego rękopisy razem z luźnymi kartkami przyszłego „Dziennika klinicznego” zostały przekazane Michaelowi Balintowi, który podjął się ich edycji oraz tłumaczenia na język angielski2 ${ }^{22}$. Wydanie dziennika okazało się jednak możliwe dopiero w połowie lat 80 . XX wieku, podobnie jak wydanie korespondencji listy do Georga Groddecka po raz pierwszy ukazały się w 1982 roku $^{23}$, a pierwszy tom korespondencji z Freudem został udostępniony szerszej publiczności dopiero w roku $1992^{24}$. Galtier zauważyła, że nawet najbliżsi węgierskiego psychoanalityka nie byli przekonani do pomysłu publikowania dziennika w okresie tuż po jego śmierci ${ }^{25}$. Obawiali się bowiem, że ostra krytyka relacji z dawnym mistrzem pogorszy recepcję dzieł teoretycznych węgierskiego lekarza; dlatego też wśród materiałów wysłanych w 1939 roku do szwajcarskiego wydawnictwa Hansa Hubera w Brnie nie znalazły się notatki z 1932 roku $^{26}$.

19 Brigitte Galtier, L'écrit des jours: lire les journaux personnels. Eugène Dabit, Alice James, Sandor Ferenczi, Paris 1997, s. 241.

${ }^{20}$ Niestety Michael Balint, który pracował nad edycją dziennika, nie podaje jej imienia.

21 Sándor Ferenczi, Journal clinique, op. cit., s. 11-13.

22 Ibidem, s. 7-10.

23 Zob. Sándor Ferenczi, Georg Groddeck, Correspondance 1921-1933, Paris 1982.

24 Sigmund Freud, Sándor Ferenczi, Correspondance, t. 1: 1908-1914, Paris 1992.

${ }^{25}$ Brigitte Galtier, L'écrit des jours: lire les journaux personnels. Eugène Dabit, Alice James, Sandor Ferenczi, Paris 1997, s. 240.

${ }^{26}$ Sándor Ferenczi, Bausteine zur Psychoanalyse. Band IV, Verlag Hans Huber, Bern 1939. 


\section{Morfologia dziennika badawczego. Autoanaliza i poszukiwanie początków}

$\mathrm{Na}$ „Dziennik kliniczny” złożyły się sto trzydzieści trzy notatki, zapisane ręcznie bądź na maszynie na luźnych kartach, rozpoczynane od tytułu oraz daty wskazującej dzień, miesiąc i rok. Psychoanalityk podejmował w nich tematy autoanalizy, paranoi, wyparcia, schizofrenii, homoseksualności, kompleksu Edypa; stawiał też pytania o skuteczność dotychczasowych technik analitycznych i faktyczny wymiar traum dziecięcych. Praktykę regularnego datowania wpisów w dziennikach badawczych Galtier proponowała określić mianem „metody chronograficznej” (fr. la méthode chronographique ${ }^{27}$. Francuska badaczka zwróciła uwagę na sprzeczność w edycji „Dziennika klinicznego” związaną z faktem, że węgierski psychoanalityk datował swoje notatki już od sierpnia 1920 roku. Sądzę, że warto zastanowić się, dlaczego do wydania dziennika Ferencziego nie włączono notatek sprzed 1932 roku, jeśli zarówno pod względem formalnym, jak i tematycznym niewiele różniły się one od tych wchodzących w skład przyszłego „Dziennika klinicznego”. Słuszna wydaje się propozycja Galtier, aby za jego część uznać też datowane zapiski z lat 1930 i 1931, wydane w ostatnim tomie Bausteine zur Psychoanalyse, niedługo po śmierci ich autora.

Dziennik Ferencziego można czytać zarówno jako dzieło naukowe, kontynuację jego wcześniejszej teorii psychoanalitycznej, jak i tekst intymistyczny. Jacques Derrida w słynnym odczycie wygłoszonym w 1994 roku w Muzeum Freuda w Londynie, opublikowanym później (2016) po polsku pod tytułem Gorączka archiwum. Impresja freudowska, zwrócił szczególną uwagę na mechanizm instytucjonalizowania wiedzy - w tym wypadku zarówno archiwum freudowskiego, jak i archiwum Sigmunda Freuda. Władza prawodawstwa, jak twierdził filozof, opiera się na wyznaczeniu granic między publicznym a prywatnym, osobistym a naukowym. Dlatego trzeba pytać:

Co, na przykład, podlega teorii bądź prywatnej korespondencji? Co podlega systemowi biografii lub autobiografii, osobistych lub intelektualnych wspomnień? Co tworzy dzieła określane mianem teoretycznych? Co jest godne tej nazwy, a co nie? ${ }^{28}$

27 Brigitte Galtier, L'écrit des jours..., op. cit., s. 253-261, 306.

28 Jacques Derrida, Goraczka archiwum. Impresja freudowska, przeł. J. Momro, Warszawa 2016, s. 14. 


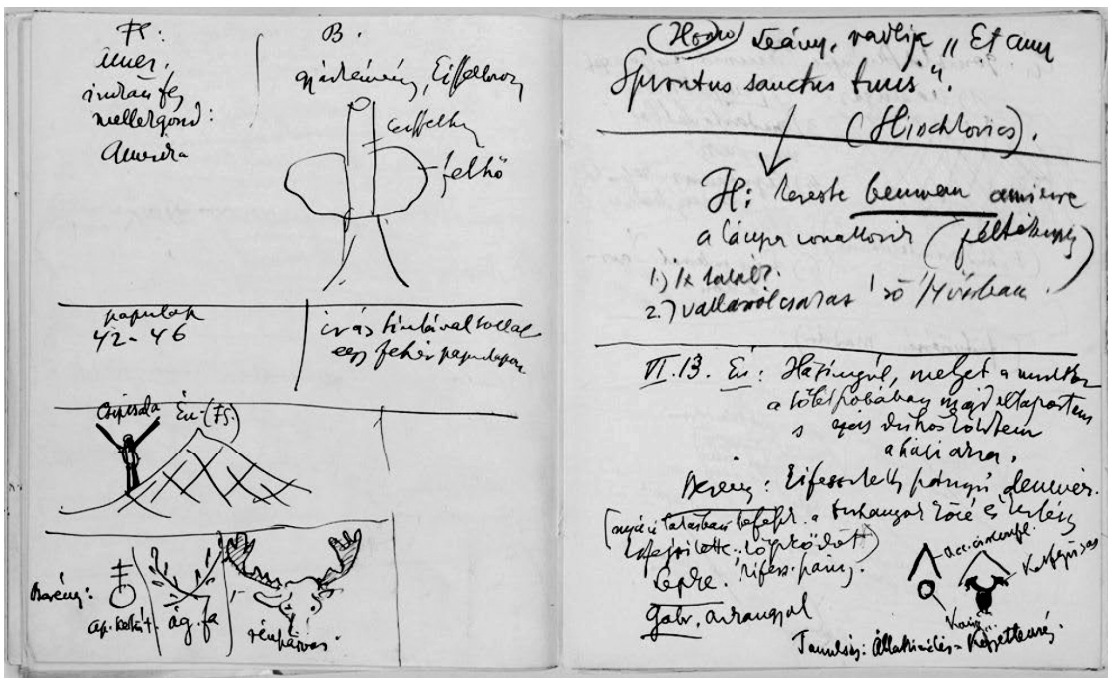

Rycina 2. Notatnik badawczy, Sándor Ferenczi Archive, Freud Museum London

Ujawnienie i dekonstrukcja granic dzielących subiektywne i obiektywne byłaby, według Derridy, twórczą metodą interpretacji archiwum. Wskazanie na nierozerwalny związek między osobistą historią a „wynalazkiem psychoanalizy: projektem wiedzy, praktyki i instytucji” ${ }^{29}$ umożliwia lekturę „Dziennika klinicznego”, w której porzuca się rozróżnienie na tekst intymny oraz analityczny, przede wszystkim po to, aby wskazać na wpływ codziennego doświadczenia na wypracowywanie teorii psychoanalitycznej.

Kluczem do takiego rozumienia dziennika badawczego psychoanalityka $z$ jednej strony jest sygnatura, rozumiana jako data umieszczona nad zapisem, z drugiej zaś dynamis - ruchoma granica między dziełem a życiem, systemem teoretycznym a jego podmiotem ${ }^{30}$. Na przykładzie Ecce homo Friedricha Nietzschego Derrida ukazał mechanizm wypychania tekstu autobiograficznego poza ramy filozofii i umieszczania go w polu pozanaukowej lektury. W wykładach poświęconych „otobiografiom” francuski filozof podkreślał związek między wolnością akademicką, autobiografią

${ }^{29}$ Ibidem, s. 15.

${ }^{30}$ Jacques Derrida, Otobiographies. L'enseignements de Nietzsche et la politique du nom propre, Paris 1984, s. 41. 
i słuchaniem (uchem) ${ }^{31}$. Pytał o relacje zachodzące między tym, co intymne (autobiografia), związane $z$ obecnością innego (ucho-słuchanie) oraz z instytucjonalizacją nauki. Podobnie jak Ecce homo, także dziennik badawczy Ferencziego przynależy do przestrzeni zarówno teoretycznej, jak i intymnej.

Derrida był przekonany, że w sygnaturze obecne jest samo życie, dlatego też doświadczenie obecności w świecie piszącego zawiera się już w samym akcie jej składania. Metoda chronograficzna Ferencziego jeszcze w latach 20. XX wieku pozwoliła mu swobodnie łączyć pracę analityka z praktykami autobiograficznymi. Sygnatura była pierwszą datą, warunkującą wszystkie następne wpisy, dającą początek notatkom wchodzącym w skład czwartego tomu Bausteine zur Psychoanalyse oraz „Dziennika klinicznego”. Przypominała ona również o momencie narodzin i, jako immanentna część zapisu intymnego, pozwalała piszącemu powracać do źródeł własnej podmiotowości. Bliskość psychoanalizy z formami autobiograficznymi staje się najlepiej widoczna w dążeniu do odkrycia początków stawania się ,ja” podmiotu. Zarówno w autobiografii, jak i w psychoanalizie droga do pozyskania wiedzy o sobie wiedzie tym samym przez autoanalizę. W korespondencji z Freudem, Groddeckiem oraz na łamach dziennika węgierski psychoanalityk szukał źródeł własnych traum we wczesnym dzieciństwie. Inaczej niż autor Totemu $i$ tabu, podstawową rolę w rozwoju dziecka przypisał matce, nie zaś ojcu ${ }^{32}$. Takie intuicje wyrażał już w 1924 roku w traktacie Thalassa, gdzie twierdził, że celem psychoanalizy jest uświadomienie sobie podstawowego pragnienia człowieka, jakim jest powrót do łona matki ${ }^{33}$.

Pierwszym krokiem dla każdego przyszłego psychoanalityka było poddanie się autoanalizie, technice wprowadzonej przez Freuda w okresie poprzedzającym publikację Objaśniania marzeń sennych ${ }^{34}$. Podczas gdy dla twórcy psychoanalizy była ona techniką intymnej rozmowy z samym sobą (w odróżnieniu od analizy odbywającej się w obecności innego), Ferenczi w dzienniku skłaniał się do wzajemnej analizy. W przeciwieństwie do tej

${ }^{31}$ Pojęcie otobiografii Derrida wyprowadza z pism Friedricha Nietzschego. Człon „oto-" pochodzi od rzeczownika oṽ, , który w starożytnej grece oznaczał "ucho". Francuski filozof czyni z otobiografii uosobienie lektury rozumiejącej, której metaforą jest wsłuchiwanie się w głos człowieka opowiadającego własną historię.

${ }^{32}$ Sándor Ferenczi, Journal clinique, op. cit., s. 160-163.

${ }^{33}$ Idem, Thalassa..., op. cit., s. 69-77.

${ }^{34}$ Por. Didier Anzieu, L'auto-analyse de Freud..., op. cit. 
pierwszej miała ona być wydarzeniem jednocześnie intymnym i społecznym, bowiem zakładała obecność drugiego podmiotu. Ferenczi zarzucił Freudowskiej technice solipsyzm oraz brak wartości poznawczych, jakie wypłynąć mogą wyłącznie z rozmowy oraz bycia słuchanym przez innego (pacjentkę lub analityka).

Niemniej sposoby praktykowania autoanalizy przez samego Freuda nie są odległe od wzajemnej analizy, którą można uznać za jej dopełnienie. Podstawowym założeniem metody Ferencziego było przeznaczanie dokładnie takiej samej ilości czasu na analizowanie pacjentek, jak i na bycie przez nie analizowanym. W tym sensie wzajemna analiza była aktem naprzemiennego słuchania i opowiadania rozmawiających ze sobą podmiotów. Warto w tym miejscu przypomnieć, że dla Freuda to nie dziennik, lecz korespondencja stała się właściwą przestrzenią praktykowania autoanalizy. Listy wysyłane do Wilhelma Fliessa dowodzą, w jak dużym stopniu rewelatorska wówczas technika była związana z codziennymi praktykami piśmiennymi i rozmową z drugą osobą ${ }^{35}$. Freud i Fliess poznali się jesienią 1887 roku. Ich korespondencja trwała siedemnaście lat, z czego okres między 1895 a 1899 rokiem należał do najintensywniejszych. Listy stanowią nie tylko niezastąpione źródło wiedzy o kształtowaniu się autoanalizy, lecz pokazują także, że źródeł samej teorii psychoanalitycznej należy szukać we wzajemnej fascynacji dwóch lekarzy. Na łamach korespondencji Freud nie raz dawał wyraz uczuciom do młodszego kolegi. W liście z 26 sierpnia 1898 roku podkreślił, że wyłącznie miłość do przyjaciela umożliwiła mu poznanie samego siebie ${ }^{36}$. Fliess szybko stał się dla niego tym, dla kogo pisał - zgodnie ze słowami samego Freuda - niemiecki lekarz był dla niego „,natchnieniem” do tworzenia ${ }^{37}$. Kilka lat wcześniej, 21 maja 1894 roku, Freud określił go jako swoje alter ego ${ }^{38}$, z którym łączyła go tajemnicza więź biologiczna ${ }^{39}$. Freud rozszerzał na łamach korespondencji dwupodział ,,ja”, charakterystyczny dla psychologicznej metody introspekcji i wprowadził do autoanalizy odbiorcę listów - trzecią instancję, zewnętrzną

35 Zob. Sigmund Freud, Lettres à Wilhelm Fliess, 1887-1904, Paris 2006.

36 Ibidem, s. 412-413.

37 Zob. list z 16 maja 1897 roku - ibidem, s. 308.

38 Ibidem, s. 97.

${ }^{39}$ Zob. list z 6 listopada 1898 roku - ibidem, s. 425. Jak zauważył François Robert, Fliess był dla Freuda wzorem, kimś, za kogo twórca psychoanalizy chciał się uważać, a więc ,,prawdziwym lekarzem” oraz „,specjalistą uniwersalnym”; zob. list z 3 lipca 1899 roku - ibidem, s. 455. 
oraz niezależną od piszącego. Niemiecki lekarz, będąc obiektem uczuć twórcy psychoanalizy, umożliwił mu podjęcie krytycznej refleksji nad kwestiami tożsamości i zmusił do konfrontacji z własną nienormatywną seksualnością, psychicznymi skutkami codziennego doświadczania antysemityzmu oraz zawodem spowodowanym odrzuceniem swoich badań wśród wiedeńskich środowisk medycznych ${ }^{40}$.

W tym sensie, odwrotnie niż zakładał Ferenczi, autoanalizy nie można traktować jako solipsystycznego dialogu z samym sobą, lecz raczej należy ją uznać za technikę rozmowy z innym, bliską przyszłemu modelowi analitycznemu węgierskiego psychoanalityka. Takie założenie okazuje się tym bardziej słuszne, że pierwsze wzmianki o wzajemności w terapii pojawiają się w korespondencji Ferencziego z Georgiem Groddeckiem ${ }^{41}$. Wymiana listów między dwoma analitykami rozpoczęła się w 1921 roku i trwała nieprzerwanie przez dwanaście lat, aż do śmierci Ferencziego. Zaledwie po czterech miesiącach korespondencji autor „Dziennika klinicznego” zwracał się już do niemieckiego lekarza: „Kochany przyjacielu” (niem. Lieber Freund) i „Kochany Groddecku” (niem. Lieber Groddeck) - były to wyrażenia, które zastąpiły sformalizowane „Szanowny Panie Kolego” (niem. Sehr geehrter Herr Kollege) ${ }^{42}$. W liście z 11 października 1922 roku Ferenczi po raz pierwszy wspomniał o „wzajemnej analizie” i o potrzebie przyznania się przed pacjentami do własnych słabości oraz nie(pełnej) wie$\mathrm{dzy}^{43}$. Już wówczas stwierdził, że leczenie innych jest środkiem do jego własnej autoanalizy. Począwszy od 1921 roku, Ferenczi razem z żoną Gizellą odbywał regularne podróże do sanatorium w Baden-Baden prowadzonego przez Groddecka. W tych krótkich okresach dwaj lekarze mogli spędzić wspólny czas na rozmowach, przypominających wzajemne analizowanie. W jednym z pierwszych listów do autora Das Buch vom Es węgierski psychoanalityk wspominał trudną relację z matką, której zarzucał niewystarczającą opiekuńczość i brak ciepła ${ }^{44}$. To właśnie figura matki połączyła obu lekarzy. Podczas gdy Ferenczi obsadzał Freuda

${ }^{40}$ Zob. Didier Anzieu, Le corps de l'oeuvre. Essais psychanalytiques sur le travail créateur, Paris 1981, s. 28-29; por. idem, L'auto-analyse de Freud..., op. cit., s. 23-27; Carl Schorske, Vienne, fin de siècle. Politique et culture, Paris 1983, s. 178-196.

${ }^{41}$ Zob. list z 11 października 1922 roku - S. Ferenczi, G. Groddeck, Correspondance..., op. cit., s. 71-75.

${ }^{42}$ Ibidem, s. 55, 64.

${ }^{43}$ Ibidem, s. 71-72.

${ }^{44}$ Ibidem, s. 55-56. 
w roli patriarchalnego i autorytarnego ojca, Groddeck był dla niego symbolem matczynej miłości ${ }^{45}$. Model pełnej otwartości w relacji analityka z pacjentami Ferenczi na dobre wprowadził do praktyki psychoanalitycznej dopiero na początku 1932 roku. Wzajemna analiza okazała się szczególnie skuteczna w pracy z R.N., kolejnym, jak pisał Christopher Fortune, po Annie O., Dorze czy Lucy R., paradygmatycznym „przypadku” w historii ruchu freudowskiego ${ }^{46}$.

W rozwoju metody analitycznej Ferencziego można wyróżnić trzy główne etapy. Pierwszym jest faza aktywnej techniki (rozwiniętej w latach 1918-1926), której początek wyznaczyło wystąpienie na VI Międzynarodowym Kongresie Psychoanalitycznym w Hadze. W artykule Weiterer Ausbau der ,aktiven Technik” in der Psychoanalyse ${ }^{47} \mathrm{~W} 1921$ roku Ferenczi stwierdził, że to pacjent, a nie analityk powinien być aktywną stroną terapii psychoanalitycznej. Okres ten zamyka zaś odczyt na kongresie psychoanalitycznym w Hamburgu w roku 1925 pod tytułem Kontraindikationen der aktiven psychoanalytischen Technik, w którym psychoanalityk diagnozował wady i granice stosowanej wówczas metody ${ }^{48}$. W kolejnym etapie, przypadającym na lata 1926-1929, wprowadził do analizy pojęcie elastyczności, które miało charakteryzować analityka. W artykule Die Elastizität der psychoanalytischen Technik twierdził, że lekarz w trakcie terapii musi dostosowywać się do potrzeb pacjenta i traktować go ze szczerą empatią (niem. Einfühlung) ${ }^{49}$.

W 1924 roku Ferenczi rozpoczął analizę Elisabeth Severn (R.N.), która okazała się jego najtrudniejszą pacjentką. Diagnozowana jako przypadek schizophrenia progressiva, R.N. była ofiarą molestowania seksualnego, którego doświadczyła jako małe dziecko. Jej przeżycie skłoniło Ferencziego do przemyślenia i krytyki Freudowskiego ujęcia traumy; 31 stycznia 1932 roku psychoanalityk zauważył, że nawet w przypadku paranoi lekarz musi szukać ziarna prawdy w opowieściach swoich pacjentów ${ }^{50}$. Podkreślenie faktycznego wymiaru ich traumatycznych przeżyć

${ }^{45}$ Ibidem, s. 55-57.

${ }^{46}$ Christopher Fortune, Sandor Ferenczi's Analysis of 'R.N.'. A Critically Important Case in the History of Psychoanalysis, "British Journal of Psychotherapy” 1993, s. 436-443.

47 Sándor Ferenczi, Weiterer Ausbau der "aktiven Technik” in der Psychoanalyse, IZP 1921, s. 33-251.

${ }^{48}$ Idem, Kontraindikationen der aktiven psychoanalytischen Technik, IZP 1926, s. 3-14.

${ }^{49}$ Idem, Die Elastizität der psychoanalytischen Technik, IZP 1928, s. 197-209.

${ }^{50}$ Idem, Journal clinique, op. cit., s. 88. 
zbliżyło węgierskiego psychoanalityka do Freudowskiej teorii uwiedzenia, porzuconej przez twórcę psychoanalizy w 1897 roku $^{51}$.

Przywrócenie w psychoanalizie problemu realnych traum dziecięcych (zazwyczaj na tle seksualnym) było jedną z przyczyn konfliktu Ferencziego z autorem Objaśniania marzeń sennych. Niechęć Freuda względem rozpoznań swego współpracownika wyszła na jaw w sierpniu 1932 roku, kiedy po raz ostatni doszło do ich spotkania w Wiedniu. Odczyt Die Leidenschaft der Erwachsenen und deren Einfluss auf Charakter und Sexualentwicklung der Kinder, zaprezentowany niedługo później na XII Międzynarodowym Kongresie Psychoanalitycznym w Wiesbaden, oraz późniejsza publikacja Sprachverwirrung zwischen den Erwachsenen und dem Kind. Die Sprache der Zärtlichkeit und der Leidenschaft ${ }^{52}$ doprowadziły do „wypchnięcia” lekarza poza psychoanalityczne centrum. W artykule Ferenczi przeciwstawił dziecięcej potrzebie czułości afektywne, nacechowane erotycznie uczucia dorosłych, z którymi dziecko (nieposiadające jeszcze potrzeb seksualnych sensu stricto) nie potrafi sobie poradzić. Ferenczi zakwestionował tym samym seksualność infantylną, w formie proponowanej przez Freuda, i starał się dowieść, że potrzeby dziecka okazywane rodzicom nie mają charakteru erotycznego, lecz wiążą się wyłącznie z potrzebą zaufania i bezpieczeństwa. To pasja (niem. Leidenschaft) - afekt projektowany przez rodzica na dziecko powodowała u niego traumę i zaburzała jego rozwój psychofizyczny.

Różnicę w poglądach Freuda i Ferencziego na seksualność infantylną oraz techniki pracy z pacjentami ujawniła też dyskusja o „technice pocałunku” (niem. Kusstechnik), zastosowanej przez węgierskiego psychoanalityka w terapii z jedną ze swoich pacjentek. O „podejrzanej etycznie” praktyce doniosła Freudowi jego uczennica Clara Thomson; 13 grudnia 1931 roku Freud pisał do autora „Dziennika klinicznego” w nadziei, że o „technice pocałunku" nie dowie się nikt więcej. Sądził bowiem, że groziłoby to ośmieszeniem całego środowiska psychoanalitycznego ${ }^{53}$. Autor Totemu $i$ tabu tłumaczył Ferencziemu, że w kulturze europejskiej pocałunek nigdy nie ma „niewinnego” znaczenia, dlatego też stanowi przekroczenie zasad etycznych przyjętych w praktyce psychoanalitycznej. Nie bez przyczyny

51 Christopher Fortune, Sandor Ferenczi's Analysis of 'R.N. A Critically Important Case in the History of Psychoanalysis, s. 436.

52 Sándor Ferenczi, Sprachverwirrung zwischen den Erwachsenen und den Kind. Die Sprache der zärtlichkeit und der Leidenschaft, „Internationale Zeitschrift für Psychoanalyse" 1933.

53 Sigmund Freud, Sándor Ferenczi, Correspondance, t. 3: 1920-1933, s. 479. 
„Dziennik kliniczny” rozpoczyna obrona „techniki pocałunku”, stanowiącej dla Ferencziego jeden $z$ kroków ku wzajemnej analizie ${ }^{54}$. Dla Freuda obraz pacjentki całującej analityka był nacechowany jednoznacznie seksualnie, podczas gdy Ferenczi uważał, że w ten sposób umożliwia analizowanym ponowne wejście $\mathrm{w}$ rolę dzieci, tak jak R.N., ciężko skrzywdzonych przez rodziców. Odtworzenie traumatycznego wydarzenia miało wyznaczać kluczową część analizy, której uczestnicy zmuszeni byli do odgrywania roli kata (analityk) i ofiary (pacjentka). W tym sensie wzajemna analiza stanowiła odpowiedź na chęć rozbicia takiego układu, opartego na przemocy i uprzedmiotowieniu pacjentki. Jednym z najważniejszych założeń węgierskiego analityka było stworzenie „bezpiecznej przestrzeni”, w której zarówno on, jak i jego pacjentka z pełną otwartością mogli mówić o sobie. W dzienniku Ferenczi stwierdzał, że jeśli jako dzieci analizowani nie otrzymali miłości ze strony rodziców, to psychoanaliza jest w istocie szansą na „uzupełnienie” takiego braku ${ }^{55}$. W oczach Ferencziego i Thomson pocałunek był okazaniem rodzicielskich uczuć i miał zapewniać pacjentkę (dziecko) o byciu w pełni akceptowaną przez analityka (rodzica). Według autora Thalassy podstawowym pragnieniem analizowanych (dzieci) było otrzymanie ciepła ze strony lekarza (rodzica), a nie zaspokojenie seksualne. Swoje przekonanie psychoanalityk wyraził ponownie w artykule Sprachverwirrung zwischen den Erwachsenen und dem Kind, tym samym rozstając się z psychoanalizą Freudowską.

W dzienniku pod datą 13 marca 1932 roku, porównując wzajemną analizę do aktywności dwojga dzieci, Ferenczi pisał:

Niektóre fazy wzajemnej analizy stanowią [...] całkowite odrzucenie przymusu i wszelkiego autorytetu; sprawiają tym samym wrażenie, że bierze w niej udział dwójka równie przestraszonych dzieci, wymieniających się własnymi doświadczeniami, które ze względu na to samo przeznaczenie rozumieją się w mgnieniu oka i instynktownie szukają wzajemnej akceptacji ${ }^{56}$.

W notatce z 29 marca 1932 roku psychoanalityk opisał zmianę w swej technice analitycznej. Zauważył bowiem, że w trakcie rozmowy wszedł w dawną pozycję pacjentek i pozwolił sprowadzić samego siebie do roli dużego dziecka (niem. Ich musste mich zum Kind degradieren), znajdującego

54 Sándor Ferenczi, Journal clinique, op. cit., s. 48-49.

55 Ibidem, s. 177-180.

${ }^{56}$ Ibidem, s. 133. 
się pod opieką analizowanej ${ }^{57}$. Od tej pory kwestionował już skuteczność jednostronnej analizy, gdzie lekarz i pacjent przyjmowali nieprzekraczalne dla nich role ${ }^{58}$.

Za kulminacyjny punkt „Dziennika klinicznego” można uznać notatkę z 31 marca 1932 roku $^{59}$. W kilku zdaniach autor rozprawił się w niej z Freudowską psychoanalizą, w której rozpoznawał autorytaryzm i patriarchalizm. Krytykując wagę kompleksu Edypa, Ferenczi stwierdził, że faza „preedypalna” nie jest pierwszym etapem psychoseksualnego rozwoju podmiotu, lecz jego punktem szczytowym ${ }^{60}$. W tym duchu pisał dalej, że zarówno dla kobiet, jak i dla mężczyzn „naturalnym” obiektem uczuć powinna być inna kobieta. Miłość do niej pozwala im bowiem symbolicznie powrócić na matczyne łono ${ }^{61}$. Ferenczi, który po wielu latach odrzucił „paternalną” relację z Freudem, był przekonany, że w czasie analizy psychoanalityk powinien przyjąć postawę pasywną, co w żadnym razie nie miało oznaczać bierności, lecz postępowanie pozbawione „męskości” agresji i rywalizacji, którą diagnozował u twórcy psychoanalizy ${ }^{62}$. W tym świetle teorię wyłożoną w „Dzienniku klinicznym” można opisać jako dążenie do „wydobycia” matki z „dna” psychoanalizy. Dla węgierskiego analityka mityczna figura oraz wyidealizowany obraz matczynej miłości były tożsame z życiem - egzystencją pozbawioną traumy odrzucenia i braku miłości. Gest zabicia ojca umożliwił narodziny matki. Ferenczi, przyjmując rolę jej akuszera, radykalnym cięciem otworzył psychoanalizę na feminizm.

\section{Bibliografia}

Anzieu D., L'auto-analyse de Freud et la découverte de la psychanalyse, Presses Universitaires de France, Paris 1988.

Anzieu D., Le corps de l'oeuvre. Essais psychanalytiques sur le travail créateur, Gallimard, Paris 1981.

Cure d'ennui. Écrivains hongrois autour Sándor Ferenczi, wyb. i oprac. Péter Ádám, Gallimard, Paris 1992.

Derrida J., Goraczka archiwum. Impresja freudowska, przeł. J. Momro, Instytut Badań Literackich PAN, Warszawa 2016.

57 Ibidem, s. 158.

58 Ibidem, s. 159.

59 Ibidem, s. 160-166.

${ }^{60}$ Ibidem, s. 162.

61 Ibidem.

62 Ibidem, s. 163. 
Derrida J., Otobiographies. L'enseignements de Nietzsche et la politique du nom propre, Éditions Galilée, Paris 1984.

Ferenczi S., Bausteine IV, Hans Huber, Bern 1939.

Ferenczi S., Die Elastizität der psychoanalytischen Technik, IZP 1928, 14(2).

Ferenczi S., Journal clinique [„Dziennik kliniczny”], przeł. zespół Coq Héron, red. M. Balint, J. Dupont, Payot, Paris 1985.

Ferenczi S., Kontraindikationen der aktiven psychoanalytischen Technik, IZP 1926, 12(1).

Ferenczi S., Sprachverwirrung zwischen den Erwachsenen und den Kind. Die Sprache der zärtlichkeit und der Leidenschaft, „Internationale Zeitschrift für Psychoanalyse” 1933, nr 19(1-2).

Ferenczi S., Thalassa. Versuch einer Genitaltheorie, IPV, Wien-Leipzig-Zurich 1924.

Ferenczi S., Weiterer Ausbau der „aktiven Technik” in der Psychoanalyse, IZP 1921, 7(3).

Ferenczi S., Groddeck G., Correspondance 1921-1933, przeł. zespół Coq Héron, Payot, Paris 1982.

Ferenczi S., Rank O., Entwicklungsziele der Psychoanalyse. Zur Wechselbeziehung von Theorie und Praxis, IPV, Wien-Leipzig-Zurich 1924.

Fortune Ch., Sandor Ferenczi's Analysis of 'R.N.'. A Critically Important Case in the History of Psychoanalysis, „British Journal of Psychotherapy” 1993, 9(4).

Freud S., Lettres à Wilhelm Fliess, 1887-1904, przeł. i red. Françoise Kahn, François Robert, Presses Universitaires de France, Paris 2006.

Freud S., Ferenczi S., Correspondance, t. 1: 1908-1914, przeł. i red. E. Brabant, E. Falzeder, P. Giampieri-Deutsch, Calmann-Lévy, Paris 1992.

Freud S., Ferenczi S., Correspondance, t. 3: 1920-1933, przeł. i red. E. Brabant, E. Falzeder, P. Giampieri-Deutsch, Calmann-Lévy, Paris 2000.

Freud S., Ferenczi S., Abraham K., Simmel E., Jones E., Zur Psychoanalyse der Kriegsneurosen, Internationaler Psychoanalytischer Verlag, Wien-Leipzig 1919.

Galtier B., L'écrit des jours: lire les journaux personnels. Eugène Dabit, Alice James, Sandor Ferenczi, H. Champion, Paris 1997.

Magnone L., Emisariusze Freuda. Transfer psychoanalizy do polskich sfer inteligenckich przed druga wojna światowa, Universitas, Kraków 2016.

Mészáros J., The Tragic Success of European Psychoanalysis. The Budapest School, „International Forum of Psychoanalysis” 1998, nr 7, s. 207-214.

Rudnytsky P.L., Charon R. (red.), Psychoanalysis and Narrative Medicine, State University of New York Press, New York 2008.

Rudnytsky P.L., Reading Psychoanalysis. Freud, Rank, Ferenczi, Groddeck, Cornell University Press, New York-London 2002.

Rudnytsky P.L., Rescuing Psychoanalysis from Freud and Other Essays in Re-vision, Karnac, London 2011.

Schorske C., Vienna, fin de siècle. Politique et culture, przeł. Y. Thoraval, Seuil, Paris 1983. Więckiewicz A., Rewolucjoniści i pariasi. Historia narodzin i zmierzchu węgierskiej psychoanalizy, w: K. Olkusz, K.M. Maj (red.), Ksenologie, Facta Ficta, Kraków 2018. 
A B S T R A C T

\section{The death of the father and mother's birth: mutual analysis in Sándor Ferenczi's Clinical diary}

The aim of the article is to present Sándor Ferenczi's Clinical Diary written in 1932. Thanks to a close reading of his journal and Ferenczi's other life-writing materials, especially correspondence with Sigmund Freud and Georg Groddeck, the authoress examines a concept of "mutual analysis" ("mutuelle Analyse"), which affected and changed a psychoanalytic theory and practice before the outbreak of the Second World War. In this article, the context of the emergence and development of psychoanalysis in Hungary has been evoked, in order to bring closer the figure of Freud's most brilliant disciple, still little known in Poland. The author analyses Ferenczi's relations with Freud in attempt to re-enact the development of his own theory - a pathway that brought him to the deconstruction of Freud's psychoanalysis.

KEY WORDS: Sándor Ferenczi, Sigmund Freud, clinical diary, mutual analysis, correspondence

\section{A B S T R A K T}

\section{Śmierć ojca i narodziny matki - wzajemna analiza w „Dzienniku klinicznym” Sándora Ferencziego}

Prezentowany tekst stanowi omówienie „Dziennika klinicznego” Sándora Ferencziego, pisanego w 1932 roku. Na podstawie analizy dziennika oraz wybranej intymistyki psychoanalityka, między innymi korespondencji z Georgiem Groddeckiem oraz Sigmundem Freudem, autorka szczegółowo opisuje koncepcję „wzajemnej analizy” (niem. mutuelle Analyse) i dowodzi, że wpłynęła ona na przekształcenie teorii oraz praktyki psychoanalitycznej przed wybuchem drugiej wojny światowej. W tekście przywołano kontekst narodzin i rozwoju psychoanalizy na Węgrzech, co pozwala w jaśniejszym świetle spojrzeć na sylwetkę jednego z najważniejszych uczniów Freuda, ciągle nieobecnego na polskim gruncie. Autorka analizuje relacje węgierskiego neurologa $z$ twórcą psychoanalizy i rekonstruuje rozwój teorii Ferencziego, prowadzącej go do zakwestionowania najważniejszych założeń psychoanalizy Freudowskiej.

SŁOWA KLUCZOWE: Sándor Ferenczi, Sigmund Freud, dziennik kliniczny, wzajemna analiza, korespondencja 


\section{Indeks osób}

Indeksem objęto tekst główny wraz z abstraktami oraz przypisy i ryciny. Gwiazdką oznaczono numery stron, na których nazwiska występują w podpisie pod ryciną, kursywą - numery stron, na których występują tylko w przypisach. Zastosowano skróty: pseud. - pseudonim, właśc. - właściwie, zob. - zobacz.

Abraham Karl 208

Achterberg Wilco 101

Ali Muhammad właśc. Clay Cassius

Marcellus Jr. 180

Alzheimer Alojz 193

Amant Frédéric 103

Antoszewska Beata 94

Anzieu Didier 210, 214, 216

Araszkiewicz Agata 181, 182

Asch Adriene 49

Ashby Margaret 147

Awdish Rana 104

Babits Mihály 208

Bachmann Ingeborg 196

Bakke Monika 178

Balint Alice 211

Balint Michael 96, 206, 211

Baranowska Barbara 10

Barański Jarosław 106

Barone Susie M. 143

Barthes Roland 84
Barton-Smoczyńska Izabela 41

Bartuszek Anna 50

Barusch Amanda 128

Bateson John 137

Baudelaire Charles Pierre 189, 190, 193

Bazzocchi Massimo 142

Bell Brown Judith 134

Bentkowski Arkadiusz 98

Beran Jiří 146

Bereś Stanisław 195

Berg Pieter van den 102

Berkeley A. Franz 112, 121

Bernhardsson Katarina 26, 28

Bijl Sandra 101

Bijlma Floris 104

Blanche, pacjentka 191

Blanker Marco 103

Błahy Jarosław 187

Bochenek Krystyna 129

Bollag Fiona 50

Borkan Jeffrey 133

Boruszkowska Iwona 168 
Boy zob. Żeleński Tadeusz

Brach-Czaina Jolanta 180, 181

Brattström Victoria 25

Brihaye Jean 190

Broca Pierre Paul 189-191

Brockmeier Jens 151

Brown Geraint C.S. 137

Brown Penelope 142, 147-150, 152

Broyard Anatole 168, 183, 185, 186

Buchowski Michał 98

Byrne Patrick 150

Caiman Kenneth C. 138

Campling Jo 49

Candlin Christopher N. 145

Candlin Sally 145

Capps Lisa 145

Carel Havi 98, 99

Carver Jonathan 137

Chakrawarty Avinsash 149

Charatsidou Ioanna 133

Charon Rita 7-11, 17-19, 23, 24, 27, 28, $46,55,67,68,70,73-76,78-80,82-85$, 87, 90, 92-94, 96, 97, 99, 107, 108, $111,113,115-122,124,134,144,145$, 150-152, 155, 167, 170, 171, 174, 206

Chmielowiec Michał 200

Chodkowska Maria 51, 52, 61, 64

Chojnacka-Kuraś Marta 10, 11

Chołuj Irena 34, 37-39

Chrapkiewicz-Gądek Angelika 52, 57, 59, 62

Cioran Emil 104

Clay Cassius Marcellus Jr. zob. Ali Muhammad

Clouser Danner K. 95

Coles Colin 137

Cott Jonathan 168

Coulthard Malcolm 147

Cozza Giorgia 41

Crafoord Clarence 18
Creswell John 144

Critchley MacDonald 189

Crul Ben 100

Csáth Géza 208

Culver Charles M. 95

Czerska Tatiana 174

DasGupta Sayantani 111, 120

Davidoff Frank 138

Davis Deborah 34

Davis-Floyd Robbie 34

Dąbek Józefa 10

Derrida Jacques 212-214

Diamant Anita 40

Dijk Teun van 156

Domańska Ewa 98

Donaldson Cindy 76

Doroszewska Antonina 10, 11, 90

Drenth Joos 103

Drijver Evert den 103

Dymna Anna 52

Dzwonkowska-Godula Krystyna 41

Dżeser, faraon 189

Eagle Chris 188-190

Eelen Gino 142

Eggly Susan 145

Ehrenheich Barbara 106

Ehrlich Susan 156

Eibenschütz Rosa 207

Eijsden Pieter van 102

Engel George 77

Engel Lilianna 96

Engström Ingemar 23

Enoch M. David 130

Ensler Eve 11, 167-183, 185, 186

Erling Valdemar 20, 22, 23

Eysenbach Gunther 135

Fairclough Norman 146

Falski Maciej 177 
Fauconnier Gilles 83, 84, 87

Ferenczi Gizele 211, 216

Ferenczi Sándor 11, 205, 206-209, 210*, 211, 212, 213*, 214-220, 222

Filar Dorota 89

Fillmore Charles 86

Fine Michelle 49

Flament Jacques 190

Fliess Wilhelm 215

Floros Georgios D. 133

Foreman George Edward 180

Fortune Christopher 217, 218

Frank Arthur W. 168

Fränkel Baruch 207

Fraser Bruce 147

Freeman Thomas R. 134

Freud Sigismund Schlomo zob. Freud Sigmund

Freud Sigmund właśc. Freud Sigismund Schlomo 206-209, 211, 212, 214, 215, 217-220, 222

Frey Jana 50

Fricker Miranda 98

Fry Jane 35

Füst Milán 208

Gadamer Hans Georg 16, 100

Galtier Brigitte 210-212

Ganeshram Prasanthi 132

Gaskin Ina May 37, 38, 40

Genette Gérard 84

Gert Bernard 95

Giedroyć Jerzy 198

Gillett Grant 138

Gliksman Łucja 195, 196

Goban-Klas Tomasz 135

Goffman Erving 147, 148

Gombrowicz Witold 202

Gosk Hanna 187, 193

Goudoever Hans, van 102

Gould Jo 34, 36,
Goupy François 113

Górnicz Mariusz 129

Grafenberg Johannes Schenck von 189

Graham Sage Lambert 144

Greenhalgh Trisha 94, 152

Grice Paul 147, 148

Groddeck Georg 207, 211, 214, 216, 217, 222

Grodecki Andrzej 62

Groopman Jerome 18, 19

Gunnarsson Britt-Louise 142

Haidet Paul 137

Hasquin-Deleval Janine 190

Hastrup Kristen 98

Hatem David 129, 136

Hawkins Anna Hunsaker 79, 130, 168

Haynal André 209

Heritage John 146

Hermoni Doron 133

Hillier Richard 137

Hitchens Christopher 173

Hoch Stefania 38,

Holloway Marquerite 79

Horthy Miklós 208

Huber Hans 211

Hudson Jones Anne 109, 110, 138

Hunter Kathryn Montgomery 128

Hunter Laura 35

Hunter Linda 35

Hurwitz Brian 94

Hydén Lars 151

Ignotus Hugó właśc. Veigelsberg Hugó 208

Imhotep, wezyr 189

Irigaray Luce 181, 182

Iskrová Daniela 74

Jaglowski Samantha M. 136

Jakobson Roman 187, 188 
James Henry 9

Janet Pierre 207

Janisiewicz Joanna 38

Janiuk Ewa 37, 39

Jankowska Aldona Katarzyna 7, 11

Jarosz Mirosław 77

Jaworska Mirka 50

Jeyachandran Vijay 132

Johnson Mark 83, 87, 93, 171

Johnson Samuel 189, 190

Jones Ernest 208

Jung Carl Gustav 207

Kalanithi Paul 105, 119, 120

Kania Ireneusz 104

Karinthy Frigyes 208

Karkowska Dorota 76, 135

Karkowski Tomasz Adam 76, 135

Karsten Jaap 102, 104

Kawczyńska-Butrym Zofia 56, 57, 77

Kay Adam 95, 104, 130

Kearney Richard 129

Keller Helen 50

Klekot Ewa 98

Kleszcz-Szczyrba Renata 41

Kłosińska Krystyna 175, 176

Kornacka Małgorzata 129

Kortko Dariusz 129

Korwin-Piotrowska Dorota 86

Kosztolányi Dezsö 208

Kovács Vilma 211

Krawczyńska-Zaucha Tatiana 34

Krisberg Kim 28

Kristeva Julia 105, 177

Krudy Gyula 208

Kulik Halina 10

Kumar Anita A. 132

Kumari Archana 149

Kuszyńska Monika 51, 59

Kuzio Anna 11
Laar Arnold van de 103

Labov William 128

Lakoff George 83, 84, 87, 93, 171

Lakoff Robin T. 147

Langacker Ronald 83, 85, 86, 93

Launer John 24

Lavrentiadis Grigorios 133

Leborgne Louis Victor pseud. Tan-Tan 190, 191, 193

LeBrun Yvan 190

Leech Geoffrey 147

Leeuw Peter de 103

Leszczyńska Stanisława 33, 36, 44

Levinson Stephen 142, 147-150, 152

Lichtenberg-Kokoszka Emilia 33, 37, 39, Lindsey Caroline 24

Linell Per 142

Lipschütz Leo zob. Lipski Leo

Lipski Leo właśc. Lipschütz Leo 11, 187, 188, 192-200, 201-204

Lipszyc Adam 187, 196

Livingstone Pnina 133

Londsale Susan 49

Long Barrier 150

Luber-Szumniak Małgorzata 10

Ładoń Monika 11, 89

Łuków Paweł 95

Maas Angela 106

Machin Sheelagh 137

Maciejowska Agnieszka 195, 200

MacIntyre Alasdair 98

Magnone Lena 206

Marszałek Lidia 49, 50, 60, 61

Masłowski Jan 81, 93

Mattingly Cheryl 28

Mazzarella Marete 25

McWilliam Carol L. 134

Mehl-Madrona Lewis 129

Mészáros Judit 209 
Midbøe Lars 23

Momro Jakub 212

Montaigne Michel de 104

Morand David A. 153

Morris David 75, 80, 89

Mountford Brenda 137

Mujica Barbara 50

Mullangi Samyukty 113

Murawska Magdalena 130

Murphy John W. 112, 121

Mursilis II, król hetycki 189

Neuger Leonard 15

Nevala Minna 142

Nicholas Barbara 138

Nietzsche Friedrich Wilhelm 213, 214

Nordberg Bengt 142

Nowaczyk Małgorzata 73, 75, 76

Nowakowska Agnieszka 167

Nowina-Konopka Maria 142

Nycz Ryszard 98, 100, 202

O’Mahony Seamus 112

Obuchowska Irena 52

Ochs Elinor 145

Okupnik Małgorzata 89, 168, 179

Oldenburg Hester 105

Orzeszkowa Eliza 175

Osińska Olga 11

Osler William 24, 80

Ostrowska Antonina 143

Ozick Cynthia 171

Paleta Alicja 41

Palm Anders 25, 26

Panasiuk Jolanta 188, 189, 190, 192, 194, 197, 198

Pasierski Tomasz 129

Pasterny Hanna 50, 51, 53

Patel Amish Dilip 132

Paterniti Debora 137
Pawlikowska-Jasnorzewska Maria 178

Pąchalska Maria 188

Picoult Jodi 50

Pijnenburg Idie 102

Pinker Steven 148

Piyush Ranjan 149

Platon 104, 176

Prevoo Warner 105

Prince Gerald 134

Przybyszewska Katarzyna 51, 59

Przyłębski Andrzej 100

R.N. zob. Severn Elisabeth

Radway Patricia 137

Radzik Teresa 45, 55, 67, 76, 129, 136

Rajamanickam Deepan 132

Rank Otto 209

Reis Shmuel 133

Reisfield Gary 87

Reiter Paulina 181

Reszka Paweł 130

Richet Charles 207

Ricoeur Paul 16, 84

Rider Elizabeth A. 129, 136

Riessman Catherine 152

Robert François 215

Robinson David 147

Rogowiec Katarzyna 52, 58, 60, 65, 66, 68

Rosicka-Jaczyńska Katarzyna 51, 53, 66

Rudnytsky Peter L. 206

Rybarkiewicz Dorota 179

Sadzik Piotr 193

Salim Shihas 132

Sanders Lisa 18

Sands Danny 81

Sapir Edward 84

Saxbe Darby 33

Saxena Mark 136

Scheltinga Marc 101 
Schlaerth Christian 112, 121

Schorske Carl 216

Selzer Richard A. 110

Serkowska Hanna 10, 89

Severn Elisabeth pseud. R.N. 205, 217, 219

Shantha Ghanshyam Palamaner Subash 132

Sheldon Frances 137

Shepherd Richard 95

Sifianou Maria 147

Sigurdson Ola 17, 18, 19, 23, 25

Silverman David 146

Simchowicz Teofil Dawid 193

Simmel Ernst 208

Sjövall Henrik 25

Skoczylas Paweł 76, 135

Skrzypek Michał 76, 77, 171, 174

Slappendel Rob 103

Sokolnicka Eugenia 206

Sokrates 33

Sommer Iris 102

Sontag Susan 168, 177, 179, 183, 185, 186

Spiers Judith 147, 148

Steciwko Andrzej 106

Stefaniak Karolina 143

Stenström Johan 25

Stewart Moira 134

Stockwell Peter 84-86, 88, 93

Strawson Galen 112

Stroh David Alex 136

Svenaeus Frederik 16, 23

Szczeklik Andrzej 78, 81, 82, 93

Szenajch Piotr 179

Szewczyk Kazimierz 95

Szugajew Aleksandra 10

Szwed Sylwia 37

Szymarek Marianna 43

Świrszczyńska Anna 43
Tabakowska Elżbieta 83, 85-87, 93

Taboł Sebastian 33

Tannen Deborah 145

Tan-Tan zob. Leborgne Louis Victor

Tataj-Puzyna Urszula 10

Thomas Jenny 147

Thomson Clara 218, 219

Thornborrow Joanna 146

Thornton Tanya 134

Thorwald Jürgen 95

Tranströmer Tomas 15

Trzebiński Jerzy 88

Turner Mark 84, 87

Turner Pauline 137

Vemuri Divya 132

Venier Jean 105

Vermeulen Riem 106

Visser Ellen de 96

Wach Małgorzata 51, 57, 60-62, 65, 68

Wadsworth Michael E.J. 147

Waitzkin Howard 146

Waletzky Joshua 128

Wallenberg Adolf 191

Wallet Cynthia 145

Wasilewski Bohdan W. 96

Wat Aleksander 191

Wawrzyński Patryk 74

Wee Bee 137

Wernicke Carl 189, 191

Wesley Tiffany 112

Weston Wayne 134

White James Boyd 171

Whorf Benjamin Lee 84

Wierciński Hubert 88

Wierzejska Jagoda 187, 198, 199, 201

Wieżel Iwona 112

Więckiewicz Agnieszka 11, 206

Wilcock Peter M. 137

Wilson George 87 
Włoszczak-Szubzda Anna 77

Wodak Ruth 142, 143

Wojaczek Magdalena 41

Wojciechowski Franciszek 56

Woods Angela 112

Worth Jennifer 37

Wyer Peter 74

Yang Ningxi 113

Zabielska Magdalena 10, 129, 130, 134

Zarconi Joseph 75

Zawadzka-Strączek Maria 167
Zembala Anna 142

Zielińska Barbara 178

Ziemba Kwiryna 183

Zierkiewicz Edyta 168

Zola Irving 145

Zuijlen Paul van 102

Zurzycka Patrycja 45, 55, 67, 76, 129, 136

Zwart Sjoerd 104

Zychla Katarzyna 50

Żelazowska-Sobczyk Magda 10, 129, 130, 134

Żeleński Tadeusz pseud. Boy 104 


\section{Człowiek w sytuacji}
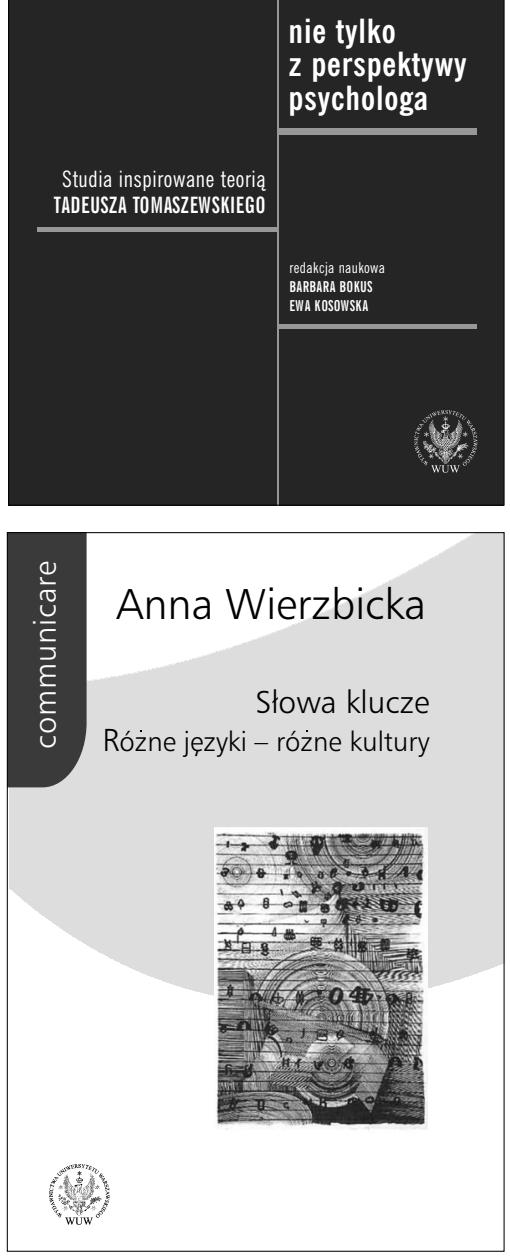
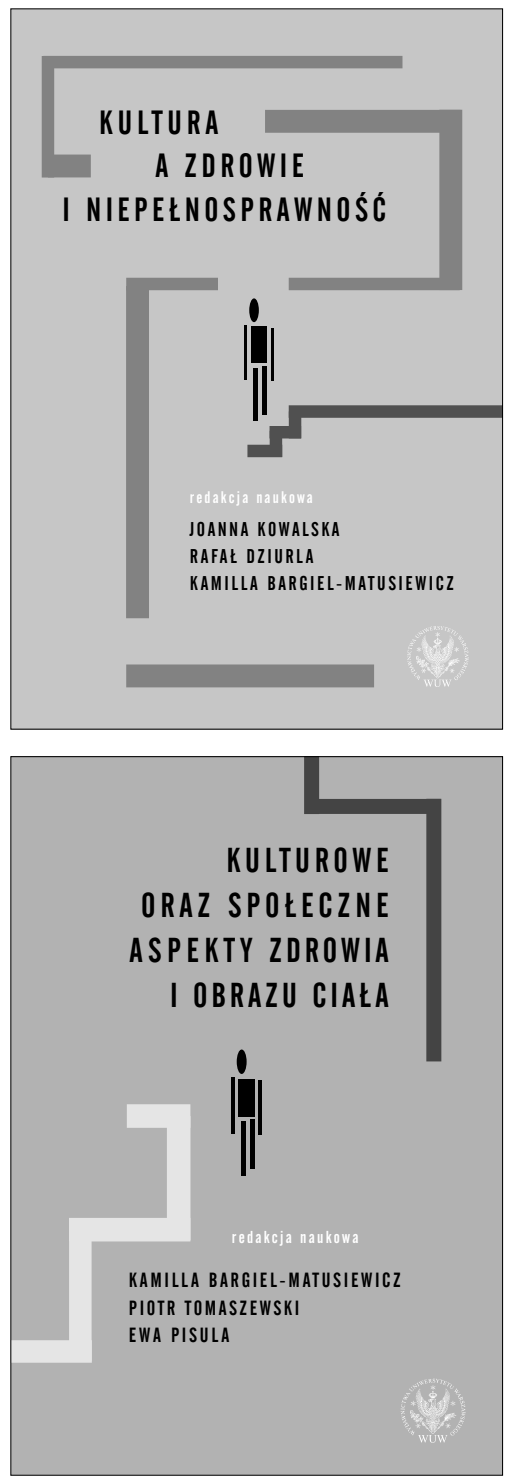

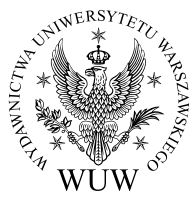

Wydawnictwa Uniwersytetu Warszawskiego

ul. Nowy Świat 4, 00-497 Warszawa

tel. 225531333

www.wuw.pl 
Publikacja ukazuje medycynę narracyjną z dwóch perspektyw: medycznej oraz literaturoznawczo-językoznawczej. Zebrane w niej teksty skupiają się na: rolimedycyny narracyjnej w praktyce klinicznej, znaczeniu narracji o doświadczeniu choroby i niepełnosprawności w dydaktyce medycznej, wybranych aspektach metodologicznych medycyny narracyjnej, narracjach lekarzy i pacjentów w dyskursie medycznym, relacjach między literaturą a medycyną oraz literaturą a logopedią i lingwistyką kliniczną.

$* * *$

Medycyna narracyjna [...] może zainteresować szerokie grono odbiorców: lekarzy, pielęgniarki i położne, rehabilitantów, psychologów, pedagogów specjalnych, wreszcie literaturoznawców, językoznawców, kulturoznawców, socjologów medycyny oraz osoby zainteresowane humanistyką medyczną.

z recenzji dr hab. Małgorzaty Okupnik

Książka ta odpowiada [... ] na cywilizacyjne wyzwania, ponieważ medycyna stała się codziennością [...] a to sprawia, że pacjenci muszą opowiadać personelowi medycznemu własne historie i własne światy przeżywane. Jesteśmy historiami, pisał Odo Marquard, a historie się opowiada. Ważne jest więc, aby ten, komu opowiadamy o sobie, o dolegliwościach, cierpieniach, obawach i lękach, potrafił umiejętnie słuchać i interpretować. Medycyna narracyjna to projekt rozumienia człowieka, a to rozumienie jest konieczne, gdy lekarz musi podnieść pacjenta z choroby, bo ten już udźwignąć siebie nie potrafi.

z recenzji dr hab. Jarosława Barańskiego

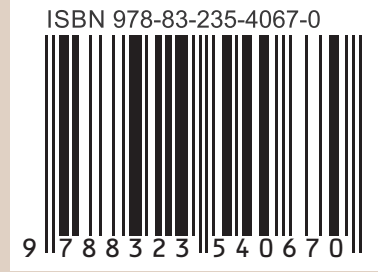

